UNIVERSIDADE DE SÃO PAULO

INSTITUTO DE GEOCIÊNCIAS

\title{
INFLUÊNCIA DE EFLUENTES DOMÉSTICOS E PETROQUÍMICOS EM SEDIMENTOS E CARAPACAS DE FORAMINÍFEROS DO CANAL DE SÃO SEBASTIÃO, SP
}

Silas Gubitoso

Orientadora: Profa Dra Wânia Duleba

\section{DISSERTAÇÃO DE MESTRADO}

Programa de Pós-Graduação em Geoquímica e Geotectônica 
"A ignorância gera confiança com mais frequência do que o conhecimento: são aqueles que sabem pouco, e não aqueles que sabem muito, que tão positivamente afirmam que esse ou aquele problema jamais será resolvido pela ciência."

(Charles Spencer Darwin) 
Dedico este trabalho à minha nonna Olga Santa Montagner Peruzzetto, exemplo de sabedoria, perseverança e amor. Agora só nos resta a eterna saudade. Obrigado por tudo! 


\section{AGRADECIMENTOS}

À minha orientadora $\operatorname{Prof}^{a} \operatorname{Dr}^{\mathrm{a}}$ Wânia Duleba, pela dedicação e conhecimento com que me orientou neste mestrado. Agradeço, especialmente, pelos conselhos dados em todos os momentos necessários. Obrigado por tudo que tem feito por mim, principalmente, por me incentivar na pesquisa e no conhecimento científico. Foi você que me ensinou que: "Aprender é descobrir aquilo que você já sabe. Fazer é demonstrar que você sabe. Ensinar é lembrar aos outros que eles sabem tanto quanto você." (Richard Bach). Nós somos todos aprendizes, fazedores, professores.

À Andreia Teodoro, pela amizade, primeiramente, e pela enorme ajuda nas discussões e nos trabalhos de campo, pelas sugestões dadas e pela paciência.

Ao meu amigo Ricardo Cunha, pela amizade e apoio incondicional ao meu trabalho, e pela ajuda com a análise sedimentológica.

À Mírian L. A. F. Pacheco, pela revisão do texto, pela enorme ajuda na discussão biológica e pelo auxílio na estatística dos dados.

Ao Prof Dr Cristiano Chiessi, pela realização das análises químicas dos foraminíferos na Alemanha e pela grande ajuda na metodologia.

À Prof ${ }^{a}$ Dr $^{a}$ Rosely Inbernon, pela ajuda na discussão dos metais.

Ao Prof Dr Décio Semensatto, pelas sugestões dadas.

Ao Prof Dr Silvio Miranda Prada, pelas análises de fósforo na Unifieo e pela ajuda no tratamento dos dados.

Ao Prof Dr Thomas Rich Fairchild pela correção do abstrat.

À Sandra Andrade, do Laboratório de Química do Igc, pelas análises de C, $\mathrm{N}$ e $\mathrm{S}$ e pela ajuda com a metodologia de análise química dos foraminíferos.

À Acme Labs, pelo atendimento e agilidade na análise química.

À CETESB e seus funcionários: Cláudia Lamparelli, José Bevilacqua, Débora Ogler de Moura, pela cessão dos dados físico-químicos da água, pela atenção e pelas campanhas à São Sebastião.

Ao meu amigo Walter da Rocha Jr., pela ajuda com a legislação ambietal, a metodologia analítica e as listas de valores-guia. estatística.

Ao Prof Dr Marcelo Monteiro da Rocha, pelo ensino dos conhecimentos de

À minha mãe e a meus irmãos e todos meus familiares que tanto amo.

A Luciana Fillipos e Juliana Braga e Silva, em todos os momentos no Laboratório de Micropaleontologia Setembrino Petri.

A Guilherme, Felipe, Evelyn, do Lab de Estudos Paleobiológicos.

À minha amiga Maria Elisa Moura e Juliana Diaz, pela ajuda no abstrat e logística em São Paulo.

A todos os meus amigos.

À FAPESP, pelo auxilio financeiro e pelas sugestões dadas a este estudo pelo seu relator. 


\section{SUMÁRIO}

I LISTA DE FIGURAS ....................................................................... 1

II LISTA DE TABELAS $\ldots \ldots \ldots \ldots \ldots \ldots \ldots \ldots \ldots$

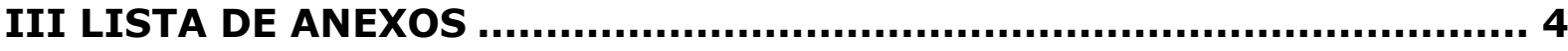

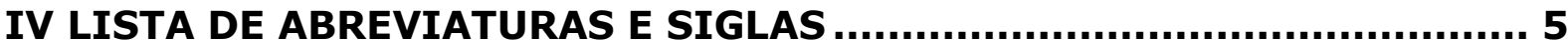

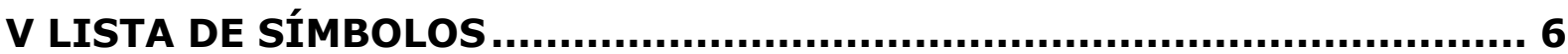

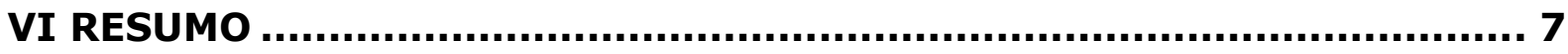

VII ABSTRACT................................................................................. 9

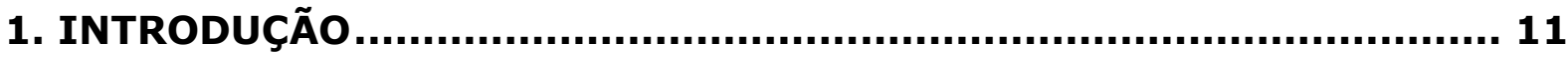

2. REVISÃO DA LITERATURA......................................................... 12

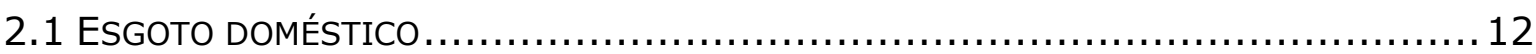

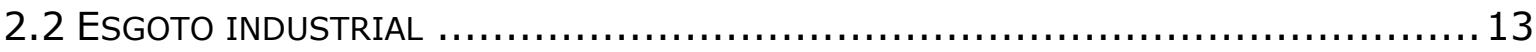

2.3 DiSPOSIÇÃO DE ESGOTOS POR VIA DE EMISSÁRIOS SUBMARINOS $\ldots \ldots \ldots \ldots \ldots \ldots \ldots 14$

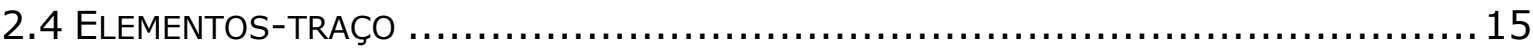

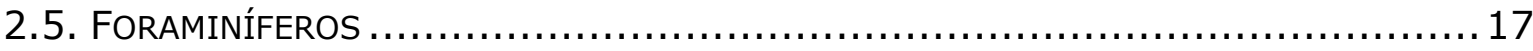

2.5.1 Ammonia tepida ...................................................... 19

3. OBJETIVOS

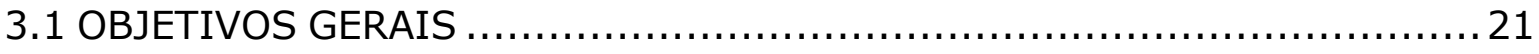

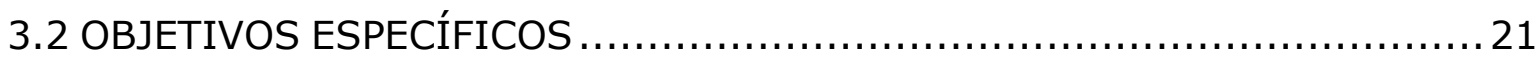

4. ÁREA DE ESTUDO ................................................................ 22

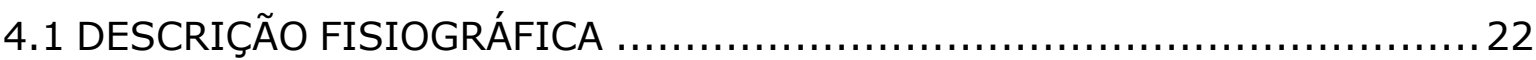

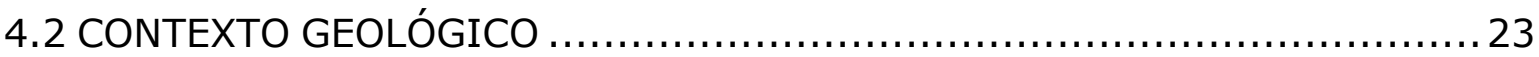

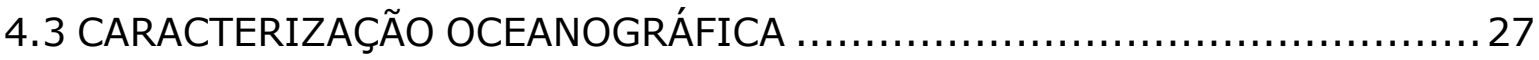

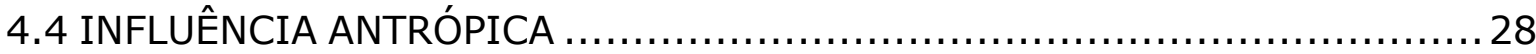

4.5 CARACTERÍSTICAS TÉCNICAS DOS EFLUENTES E DOS EMISSÁRIOS ....... 29

4.5.1 O Araçá................................................................. 29

4.5.2 O Terminal Petrolífero Almirante Barroso (TEBAR) ...................... 30

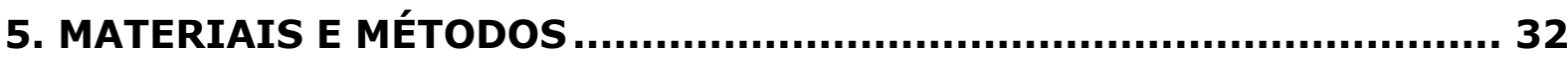

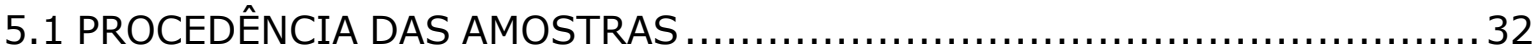

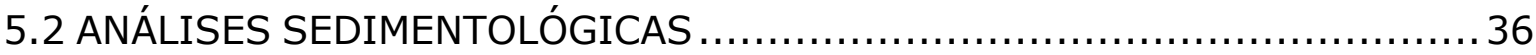

5.2.1 Análises Granulométricas ............................................ 36

5.2.2 Análise Geoquímica ................................................. 38 
5.3 ElEMENTOS-TRAÇO CONTIdOS NAS CARAPAÇAS DE ForaminÍFEROS $\ldots \ldots \ldots \ldots \ldots \ldots . \ldots 2$

5.3.1 Análise qualitativa de elementos-traço ............................. 43

5.3.2 Limpeza das carapaças .......................................... 43

5.3.3 Análise quantitativa de elementos-traço ............................. 44

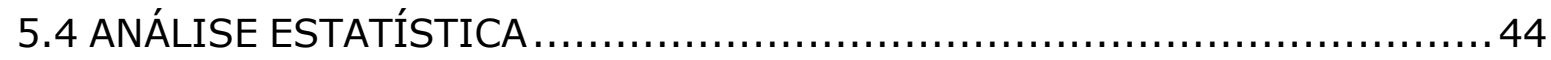

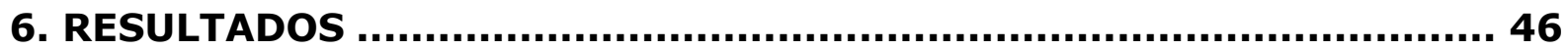

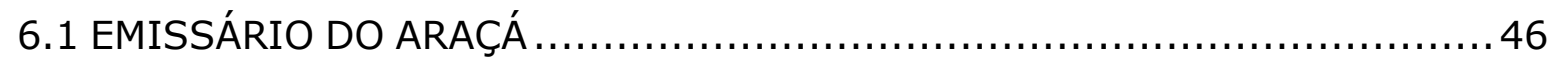

6.1.1 Parâmetros Físico-químicos e Microbiológicos.........................46

6.1.2 Dados Sedimentológicos............................................. 46

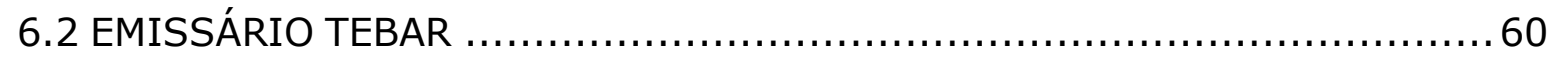

6.2. 1 Parâmetros Físico-químicos e Microbiológicos..........................60

6.2.2 Dados Sedimentológicos............................................ 61

6.3 ELEMENTOS-TRAÇO CONTIDOS NAS CARAPAÇAS DE FORAMINÍFEROS $\ldots \ldots \ldots \ldots \ldots \ldots .74$

6.3.1 Análise qualitativa ................................................ 74

6.3 .2 Análise quantitativa ................................................ 80

7. DISCUSSÃO.......................................................................... 88

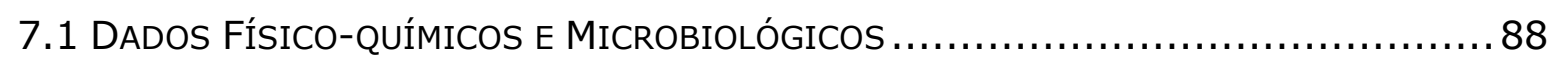

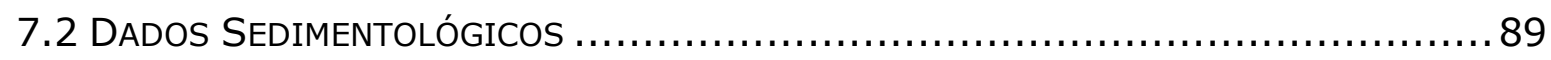

7.3 ElEMENTOS-TRAÇO CONTIDO NAS CARAPAÇAS DE ForAminíFEROS $\ldots \ldots \ldots \ldots \ldots \ldots . . \ldots 8$

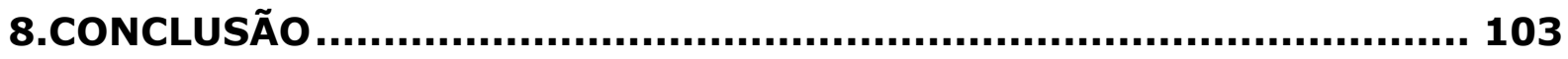

VIII ANEXOS......................................................................... 105

IX REFERÊNCIAS BIBLIOGRÁFICAS ........................................ 112 


\section{LISTA DE FIGURAS}

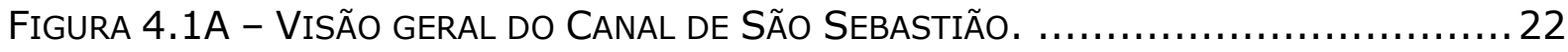

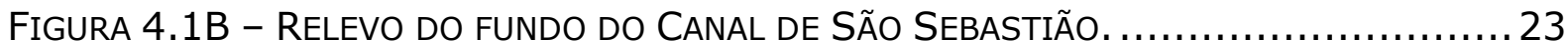

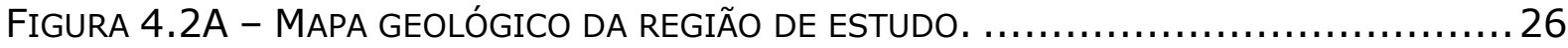

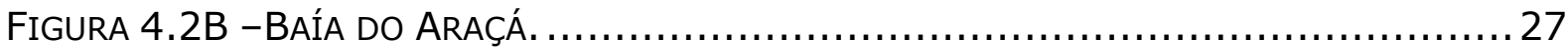

Figura 4.4 - Terminal Petrolífero Almirante Barroso (TEBAR). .................. 29

FIGURA 4.5.1 - ESQUEMA DE LOCALIZAÇÃO DO EMISSÁRIO SUBMARINO DE ESGOTO DO ARAÇÁ.

FIGURA 4.5.2 - ESQUEMA DE LOCALIZAÇÃO DO EMISSÁRIO SUBMARINO DE ESGOTO DO TEBAR.

Figura 5.1A - REDE AMOSTRAL NA ÁREA DE INFLUÊNCIA do EMISSÁRIO DO ARAÇÁ......... 33

FigURA 5.1B - REDE AMOSTRAL NA ÁREA DE INFLUÊNCIA DO EMISSÁRIO DO TEBAR....... 34

FIGURA $5.1 \mathrm{C}$ - LOCALIZAÇÃO DO PONTO CONTROLE CTR ............................. 35

FIGURA 5.4 - CONSTITUINTES DO DIAGRAMA DE CAIXA (BOXPLOT) $\ldots \ldots \ldots \ldots \ldots \ldots \ldots \ldots . \ldots . \ldots \ldots$

FIGURA 6.1.2.1 - DISTRIBUIÇÃO GRANULOMÉTRICA E CLASSIFICAÇÃO DOS SEDIMENTOS NA REGIÃO DO EMISSÁRIO SUBMARINO DO ARAÇÁ................................49

FiguRA 6.1.2.2.1A - CONCENTRAÇÕES EM \% DE CARBONATO DE CÁlCiO, CARBONO ORGÂNICO, NITROGÊNIO, ENXOFRE E LOCALIZAÇÃO DAS AMOSTRAS DA REGIÃO DO EMISSÁRIO DO ARAÇÁ. 53

FIGURA 6.1.2.2.1B - CONCENTRAÇÕES EM \% DE FÓSFORO TOTAL, FÓSFORO ORGÂNICO, FÓSFORO INORGÂNICO, RAZÃO C/S E C/N E LOCALIZAÇÃO DAS AMOSTRAS DA REGIÃO DO EMISSÁRIO DO ARAÇÁ.

FIGURA 6.1.2.2.2 - CONCENTRAÇÕES DE ELEMENTOS MAIORES E TRAÇO CONTIDOS NO SEDIMENTO DA REGIÃO DO EMISSÁRIO DO ARAÇÁ.

FIGURA 6.2.2.1 - DISTRIBUIÇÃO GRANULOMÉTRICA E CLASSIFICAÇÃO DOS SEDIMENTOS DA REGIÃO DO EMISSÁRIO SUBMARINO DO TEBAR. .

Figura 6.2.2.2.1A - CONCENTRAÇÕES EM \% DE CARBONATO DE CÁlCiO, CARBONO ORGÂNICO, NITROGÊNIO, ENXOFRE E LOCALIZAÇÃO DAS AMOSTRAS DA REGIÃO DO EMISSÁRIO DO TEBAR.

FIGURA 6.2.2.2.1B - CONCENTRAÇÕES EM PORCENTAGEM DE FÓSFORO TOTAL, FÓSFORO ORGÂNICO, FÓSFORO INORGÂNICO, RAZÃO C/S E C/N E LOCALIZAÇÃO DAS AMOSTRAS DA REGIÃO DO EMISSÁRIO DO TEBAR. 
FIGURA 6.2.2.2.2 - CONCENTRAÇÕES DE ELEMENTOS MAIORES E TRAÇO CONTIDOS NO

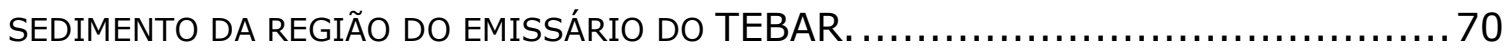

FiguRA 6.3.1.1A - IMAGENS DE CARAPAÇAS NÃO CORADAS DE A. TEPIDA DO EMISSÁRIO DO ARAÇÁ. 75

FIGURA 6.3.1.1B - GRÁFICOS COM AS ANÁLISES DE EDS DAS CARAPAÇAS NÃO CORADAS DE A. TEPIDA. 76

FiguRA 6.3.1.2A - IMAGENS DE CARAPAÇAS DE $A$. TEPIDA DO EMISSÁRIO DO TEBAR . ... 78 Figura 6.3.1.2B - GRÁFICOS COM AS ANÁLISES DE EDS DAS CARAPAÇAS DE $A$. TEPIDA. . 79 DiAgRAMA BOXPLOT 6.3.2.1 - ElEMENTOS-TRAÇO EM PPB DAS CARAPAÇAS DE A. TEPIDA DA REGIÃO DO EMISSÁRIO DO ARAÇÁ.......................................... 81 DiAgRAMA BOXPLOT 6.3.2.2 - ElEMENTOS-TRAÇO EM PPB DAS CARAPAÇAS DE A. TEPIDA DA REGIÃO DO EMISSÁRIO DO TEBAR. 85 


\section{LISTA DE TABELAS}

TABELA 6.1.2.1 - GRANULOMETRIA DOS SEDIMENTOS AMOSTRADOS NA REGIÃO DO EMISSÁRIO SUBMARINO DO ARAÇÁ. 48

TABELA 6.1.2.2.1 - DAdOS DE CARBONATO DE CÁLCIO, CARBONO ORGÂNICO, NITROGÊNIO, ENXOFRE, FÓSFORO ORGÂNICO, FÓSFORO INORGÂNICO E RAZÕES C/S E C/N DA REGIÃO

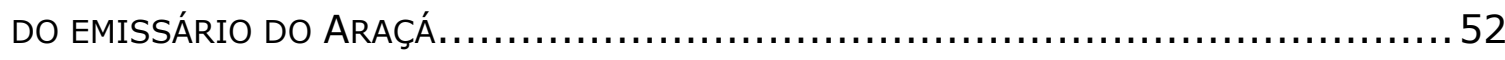

TABELA 6.1.2.2.2B - VALORES DO FATOR DE ENRIQUECIMENTO (EF) PARA OS ELEMENTOS MAIORES E TRAÇO NO SEDIMENTO DA REGIÃO DO EMISSÁRIO DO ARAÇÁ $\ldots \ldots \ldots \ldots \ldots . \ldots 7$

MATRIZ 6.1.2.2.3 - MATRIZ DE CORRELAÇÃO EXIBINDO OS COEFICIENTES DE PEARSON PARA OS DADOS DE FINOS (SILTE + ARGILA), AREIA, CARBONATO, CARBONO ORGÂNICO, ENXOFRE, NUTRIENTES, ELEMENTOS MAIORES E TRAÇO DO EMISSÁRIO DO ARAÇÁ. ...... 59

TABELA 6.2.2.1 - GRANULOMETRIA DOS SEDIMENTOS AMOSTRADOS NA REGIÃO DO EMISSÁRIO SUBMARINO DO TEBAR

TABELA 6.2.2.2.1 - DADOS DE CARBONATO DE CÁLCIO, CARBONO ORGÂNICO, NITROGÊNIO, ENXOFRE, FÓSFORO ORGÂNICO, FÓSFORO INORGÂNICO E RAZÕES C/S E C/N DA REGIÃO DO EMISSÁRIO DO TEBAR 66

TABELA 6.2.2.2.2B - VALORES DO FATOR DE ENRIQUECIMENTO (EF) PARA OS ELEMENTOS MAIORES E TRAÇO NO SEDIMENTO DA REGIÃO DO EMISSÁRIO DO TEBAR.

MATRIZ DE CORRELAÇÃO 6.2.2.2.3 - MATRIZ DE CORRELAÇÃO EXIBINDO OS COEFICIENTES

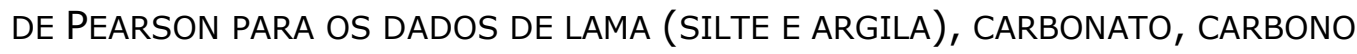
ORGÂNICO, ENXOFRE, NUTRIENTES, ELEMENTOS MAIORES E TRAÇO DO EMISSÁRIO DO TEBAR.

MATRIZ 6.3.2.1A - MATRIZ DE CORRELAÇÃO EXIBINDO OS COEFICIENTES DE PEARSON PARA OS ELEMENTOS MAIORES E TRAÇO CONTIDOS NO SEDIMENTO COM ELEMENTOS-TRAÇOS DAS CARAPAÇAS DE FORAMINÍFEROS DO EMISSÁRIO DO ARAÇÁ.

MATRIZ 6.3.2.1B - MATRIZ DE CORRELAÇÃO EXIBINDO OS COEFICIENTES DE PEARSON PARA OS DADOS DE ELEMENTOS-TRAÇOS DAS CARAPAÇAS DE FORAMINÍFEROS DO EMISSÁRIO DO ARAÇÁ.

MATRIZ 6.3.2.2A - MATRIZ DE CORRELAÇÃO EXIBINDO OS COEFICIENTES DE PEARSON PARA OS ELEMENTOS MAIORES E TRAÇO DO SEDIMENTO E ELEMENTOS-TRAÇOS DAS CARAPAÇAS DE FORAMINÍFEROS DO EMISSÁRIO DO TEBAR.

MATRIZ 6.3.2.2B - MATRIZ DE CORRELAÇÃO EXIBINDO OS COEFICIENTES DE PEARSON PARA OS DADOS DE ELEMENTOS-TRAÇOS DAS CARAPAÇAS DE FORAMINÍFEROS DO EMISSÁRIO DO TEBAR. 


\section{LISTA DE ANEXOS}

TABELA 6.1.1 - PARÂMETROS FÍSICO-QUÍMICOS DA REGIÃO DO EMISSÁRIO SUBMARINO DO ARAÇÁ. 106

TABELA 6.1.2.2.2A - DADOS DE METAIS E ELEMENTOS-TRAÇOS CONTIDOS NO SEDIMENTO DA

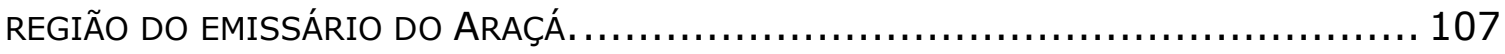

TABELA 6.2.1- PARÂMETROS FÍSICO-QUÍMICOS DA REGIÃO DO EMISSÁRIO SUBMARINO DO

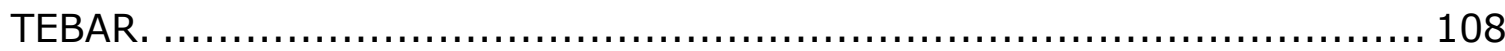

TABELA 6.2.2.2.2A - DADOS DE METAIS E ELEMENTOS-TRAÇOS CONTIDO NO SEDIMENTO DA

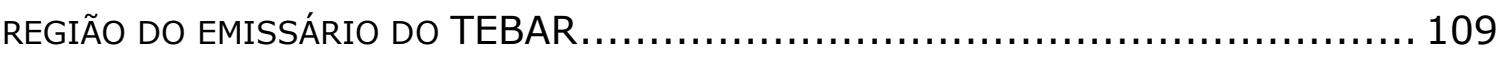

TABELA 6.3.2.1 - CONCENTRAÇÃO DE ELEMENTOS-TRAÇO DAS CARAPAÇAS DE A. TEPIDA DA

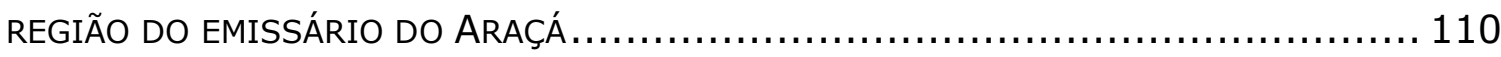

TABELA 6.3.2.2 - CONCENTRAÇÃO DE ELEMENTOS-TRAÇO DAS CARAPAÇAS DE A. TEPIDA DA REGIÃO DO EMISSÁRIO DO TEBAR 


\section{LISTA DE ABREVIATURAS E SIGLAS}

CETESB - Companhia Ambiental do Estado de São Paulo

SABESP - Companhia de Saneamento Básico do Estado de São Paulo

CONAMA - Conselho Nacional do Meio Ambiente

TEBAR - Terminal Petrolífero Almirante Barroso

EPA - Environmental Protection Agency

TEL - Nível limiar de efeitos

PEL - Nível provável de efeitos

CCME - Canadian Council of Ministers of the Environment

ETE - Estação de tratamento de efluentes

SAO - Sistema separador de água e óleo

M.O. - Matéria orgânica

Máx. - Valor máximo

Mín. - Valor mínimo

ppm - partes por milhão

ppb - partes por bilhão

CTR - Ponto Controle

C org - Carbono Orgânico

P total - Fósforo total

P org - Fósforo orgânico

P inorg - Fósforo inorgânico

MEV - Microscópio Eletrônico de Varredura

EDS - Espectrômetro de Energia Dispersiva

$E F$ - Fator de enriquecimento

FC - Foraminífero corado

F - Foraminífero não corado 
V LISTA DE SÍMBOLOS

$\bar{x}$ - média

$s$ - desvio padrão 


\section{RESUMO}

O presente estudo teve por objetivo avaliar a influência de esgotos domésticos e petroquímicos, dispostos por via de emissário submarino, nas composições físico-químicas e microbiológicas da coluna d'água e na geoquímica dos sedimentos, bem como investigar uma possível relação entre o meio e a composição química das carapaças do foraminífero Ammonia tepida.

Para atingir tal objetivo foram coletadas 10 amostras de água e de sedimento superficial, no entorno dos emissários do Araçá e do Terminal Petrolífero Almirante Barroso (TEBAR), além de um ponto controle, no canal de São Sebastião, SP, em março e abril de 2007. Em cada amostra de água foram realizadas análises físico-químicas e microbiológicas. Nos sedimentos, foram realizadas análises granulométricas e geoquímicas (macronutrientes, elementos maiores e traços). Do sedimento, carapaças coradas (indivíduos vivos) e não coradas (mortos) de $A$. tepida foram triadas e analisadas em espectrômetros de energia dispersiva (MEV-EDS) e de emissão atômica (ICP-OES) para análise química dos elementostraços.

Os resultados das análises físico-químicas e microbiológicas da água, indicaram que a coluna d'água não estava contaminada, no momento da amostragem, pois todos os valores obtidos estavam dentro dos limites exigidos pela resolução do CONAMA, no 357/2005.

Os resultados granulométricos mostraram que o sedimento é litoclástico e mais psamítico no Araçá, e mais pelítico, no TEBAR. Já os dados geoquímicos de carbono orgânico, nitrogênio, enxofre e fósforo revelaram que ambas as regiões são propícias ao enriquecimento desses elementos.

A concentração de elementos-traço, na maioria dos pontos estudados, nas duas áreas, quando comparada aos valores guia de causaefeito, não foi considerada tóxica para a biota marinha. Contudo, foi observado enriquecimento significativo de cádmio, em certas áreas no 
Araçá, e de bário, no TEBAR. A concentração deste último elemento, provavelmente, está relacionada à água de produção do terminal.

Os elementos-traço das carapaças de $A$. tepida coradas, em ambos os emissários, apresentaram maior número de correlações significativas com o sedimento, sugerindo que carapaças de foraminíferos mortos estão mais susceptíveis ao viés dos processos diagenéticos. No TEBAR, foram observadas correlações significativas positivas entre os teores de $\mathrm{Co}, \mathrm{Cr}$, $\mathrm{Mn}$ e $\mathrm{Pb}$ nos sedimentos e os elementos-traço das carapaças coradas. Já no Araçá, somente os teores de $\mathrm{Cr}$ correlacionaram-se positiva e significativamente aos teores encontrados nas carapaças coradas. Isto corrobora com a influência da composição do sedimento nas reações intracelulares dos foraminíferos, refletidas na construção do exoesqueleto.

Diante do exposto, os resultados deste estudo trouxeram luz a novas questões que permitiram inferir que a auto-depuração da água do mar, em ambas as regiões, e a estação de tratamento de efluentes, no TEBAR, não se revelaram eficientes na diluição e/ou remoção do conteúdo de nutrientes, matéria orgânica e elementos maiores e traço.

Palavras-chave: Emissário submarino, esgoto doméstico, esgoto petroquímico, especiação de fósforo, elementos maiores e traço no sedimento marinho, carapaça de foraminíferos bentônicos, Ammonia tepida, canal de São Sebastião. 


\section{ABSTRACT}

The goal of this study was to evaluate the influence of domestic and petrochemical sewage, discharged through a submarine sewage outfall, on the physicochemical and microbiological composition of the water column and the geochemistry of sediments. As well as to investigate a possible relationship between the environment and the chemical composition of Ammonia tepida foraminifer's tests.

The area where this study was focused on two sewage emissaries: Araçá and Almirante Barroso Petroliferous Terminal (TEBAR), both located in São Sebastião Channel, São Paulo, Brazil.

To achieve this goal, 10 water and bottom sediments samples in in March and April of 2007 were collected form each outfall. A background sample also collected as a control.

For each water sample physicochemical and microbiological analyses were carried out and, in the sediments, grainsize and geochemical (macronutrients, major and trace elements) were analyzed. Trace elements found in the tests of stained (live) and unstained (dead) Ammonia tepida were identified by scanning electron microscopy using energy dispersive spectroscopy (SEM-EDS) and by inductively coupled plasma optical emission spectrometry (ICP-OES).

The analysis of the water samples showed that the water column was not contaminated. All the concentrations obtained were in accordance with the National Environmental Council (CONAMA) limits.

Grain size analysis, demonstrated that the sediments are of terriginous origin, being mainly psamitic in Araçá and mainly pelitic in TEBAR. The geochemical data of organic Carbon, Nitrogen, Sulphur and Phosphorus revealed that both regions are susceptible to enrichment in these elements.

In both areas, the concentration of trace elements, when compared to quality guideline values, was not considered toxic for marine life. However, significative enrichment in Cadmium in certain areas of Araçá and Barium in TEBAR. The latter is probably related to the terminal's water production.

In both outfalls, it was observed a significant correlation between the trace elements in the live $A$. tepida's tests and the sediment, which suggests that the dead foraminifera are more susceptible to diagenical bias. In TEBAR the correlations observed were significative and positive among the elements $\mathrm{Co}, \mathrm{Cr}$, 
$\mathrm{Mn}$ and $\mathrm{Pb}$ present in the sediments and the trace elements of the stained tests. In the Araçá outfall, only the Cr levels correlate significative and positively with the levels found in the tinged tests. This shows that sediment composition influences the intracelular reactions in the forminifera, which reflected in the exoskeleton's building.

Given the above, the results of this study brought up new questions that allowed to infer that sea water depuration at both outfalls, as well as at sewage treatment plant, in TEBAR was not sufficient to dilute and/or remove the nutrient content, the organic matter and major and trace elements of the sewage.

Key words: Submarine sewage outfall, domestic sewage, petrochemical sewage, organic and inorganic phosphorus, major elements and trace elements in marine sediments, benthic foraminifera's tests, Ammonia tepida, São Sebastião channel; 


\section{INTRODUÇÃO}

O monitoramento das águas circunjacentes aos emissários do litoral paulista, estruturado na legislação ambiental, por meio das resoluções Federais do CONAMA (Conselho Nacional do Meio Ambiente), relacionada à qualidade das águas litorâneas, foi implementado pela CETESB (Companhia Ambiental do Estado de São Paulo), em 2002. Estes monitoramentos tiveram início em função do crescente número de emissários submarinos implantados no estado de São Paulo, na década de 1990.

Como as resoluções no 274/2000 e 357/2005, resultantes de revisões da Resolução n’ 20/1986, não são específicas para o controle dos lançamentos de emissários, em 2003, foram iniciadas coletas de sedimentos, com o objetivo de avaliar o impacto que a disposição de efluentes exerce no mar. Para o efeito deste estudo, foi estabelecido um convênio entre a CETESB e o Laboratório de Micropaleontologia do Instituto de Geociências da Universidade de São Paulo (IGcUSP), sob a coordenação da Profa Dra Wânia Duleba (Escola de Artes, Ciências e Humanidades, Universidade de São Paulo).

Neste contexto, tiveram início as atividades inerentes ao projeto de mestrado intitulado "Influência de efluentes domésticos e petroquímicos em sedimentos e carapaças de foraminíferos do Canal de São Sebastião, SP", realizado junto ao Programa de Pós-graduação em Geoquímica e Geotectônica, do IGcUSP e a subsidiado pela FAPESP (processo no 2006/58766-5; 2009/51031-8)

As amostragens realizadas durante este mestrado foram inseridas em uma das campanhas de coleta efetuadas pela CETESB, na região dos emissários do Araçá e do Terminal Petrolífero Almirante Barroso (TEBAR/Petrobrás), em São Sebastião, SP, durante o verão de 2007 (março e abril).

Este trabalho forneceu dados geoquímicos inéditos, que perpassaram e cotejaram relevantes considerações sobre os efeitos dos efluentes doméstico e industrial no meio bentônico, nas áreas circunjacentes aos difusores dos emissários submarinos de esgoto do TEBAR e do Araçá. Estes dados, por sua vez, servem como subsídio para outros estudos, tais como a dinâmica populacional de foraminíferos, e os compostos químicos orgânicos (hidrocarbonetos aromáticos policíclicos), em andamento no Laboratório de Micropaleontologia (IGcUSP). 


\section{REVISÃO DA LITERATURA}

\subsection{ESGOTO DOMÉSTICO}

O esgoto doméstico é composto de águas de banho e de lavagem de utensílios, restos de comida, sabões, detergentes, urina, fezes e vários outros produtos descartáveis (e.g. papéis não biodegradáveis, pontas de cigarros, absorventes etc.). Cerca de 99,9 \% do esgoto está sob a forma líquida e apenas $0,1 \%$, sob a forma sólida. Mesmo passando por uma série de tratamentos (précondicionamento primário e secundário), os esgotos domésticos, contêm grande variedade de resíduos, que podem, em elevado nível, afetar o ecossistema marinho, a saúde pública e a estética local (Werme \& Hunt, 2004). Os constituintes mais nocivos incluem organismos patogênicos, contaminantes tóxicos, matéria orgânica, nutrientes, óleo, graxa, materiais sólidos e/ou flutuantes.

Organismos patogênicos, como bactérias, vírus e protozoários, encontrados em resíduos humanos e animais, podem causar enfermidades a seres humanos, pelo consumo de frutos do mar e pelo contato físico com a água contaminada.

Contaminantes tóxicos incluem metais pesados, bifenilas policlorados (PCBs), pesticidas, hidrocarbonetos policíclicos aromáticos (HAPs) e alifáticos, surfactantes e fenóis. Todos estes contaminantes tendem a se acumular nos organismos marinhos, através da cadeia trófica, afetando seus ciclos de vida e, conseqüentemente, quando ingeridos, a saúde humana (Hershelman et al., 1981).

A matéria orgânica (M.O.) é o maior constituinte dos esgotos e é formada, principalmente, de compostos de proteínas (40 a $60 \%$ ), carboidratos (25 a 50 $\%)$, gordura e óleos (10 \%) e uréia. Uma vez lançada no meio marinho, a M.O. é rapidamente degradada por bactérias, que, por sua vez, liberam compostos a base de carbono, enxofre, nitrogênio e fósforo.

Em ambientes marinhos não poluídos, os nutrientes essenciais ao crescimento das algas e das macrófitas são o fósforo $(P)$ e o nitrogênio $(N)$. Já em regiões submetidas a aporte de esgotos domésticos, as concentrações de $\mathrm{P}$ e $\mathrm{N}$ são muito elevadas, pois vários subprodutos das atividades humanas (i.e. fezes, urina, detergentes) são, essencialmente, constituídos de P e N (Stoker, 1989; Osório \& Oliveira, 2001). 
O aumento nas concentrações de $\mathrm{P}$ e $\mathrm{N}$ desencadeia o processo de eutrofização das águas, culminando em uma série de distúrbios na cadeia trófica. Neste contexto, sólidos em suspensão diminuem a penetração de luz e afetam o crescimento e a produtividade de algas e outras plantas marinhas. Além disso, juntamente com óleo, graxas e detritos, flutuantes sólidos prejudicam a estética visual da superfície da água.

\subsection{ESGOTO INDUSTRIAL}

De acordo com a Norma Brasileira (NBR 9800/1987), efluente industrial é o despejo líquido proveniente do estabelecimento industrial, e compreende emanações de processo industrial, águas de refrigeração e pluviais poluídas, bem como esgoto doméstico. Por muito tempo não existiu a preocupação de caracterizar a geração de efluentes líquidos industriais e de avaliar seus impactos no ambiente. No entanto, a legislação vigente e a conscientização ambiental fizeram com que algumas indústrias desenvolvessem atividades para quantificar a vazão e determinar a composição dos efluentes industriais.

As características físicas, químicas e biológicas do efluente industrial variam com o tipo de indústria, período de operação, matéria-prima utilizada e reutilização da água. O efluente líquido pode ser solúvel com sólidos em suspensão, com ou sem coloração, orgânico ou inorgânico, com temperatura baixa ou elevada. Entre as determinações mais comuns para caracterizar a massa líquida estão as determinações físicas (temperatura, cor, turbidez e sólidos), as químicas ( $\mathrm{pH}$, alcalinidade, teor de matéria orgânica, metais) e as biológicas (presença e concentração de bactérias, protozoários e vírus).

Tratar os efluentes industriais é uma exigência legal e de imagem pública. No caso de indústrias petroquímicas, os efluentes passam por série de processos físicos, químicos e biológicos para tratamento e descarte dos resíduos de petróleo e derivados - nafta e diesel. Esses processos ocorrem em Estações de Tratamento de Esgoto (ETE), geralmente instaladas nas próprias indústrias. 


\subsection{DISPOSIÇÃO DE ESGOTOS POR VIA DE EMISSÁRIOS SUBMARINOS}

Segundo Gonçalves et al. (1997), emissário submarino é a tubulação utilizada para lançamento de esgotos sanitários ou industriais no mar, aproveitando-se a elevada capacidade de auto-depuração das águas marinhas que promovem a diluição, a dispersão e o decaimento de cargas poluentes a elas lançadas. Atualmente, os emissários submarinos são considerados complementares e integrados aos sistemas de tratamento e disposição de esgotos sanitários nas cidades litorâneas.

O seu funcionamento é considerado simples e de baixo custo de operação em relação à estação completa de tratamento de efluentes, posto que o efluente do emissário seja apenas pré-tratado. A premissa básica para a utilização deste método sanitário é a viabilização da balneabilidade das praias pela população costeira (Occhipinti, 1972; Agudo, 1983, Marcellino, 2000).

Em alguns países, o efluente disposto por via de emissários, passa, pelo menos, por tratamento primário (e.g., Sydney - Austrália e San Diego - EUA) e, partes, por secundário (67,\% primário, 33 \% secundário, Los Angeles - EUA) (Philip \& Pritchard, 1996) ou até mesmo terciário (e.g., Boston - EUA, Werme \& Hunt, 2004).

O primeiro emissário do mundo foi construído em 1910 em Santa Mônica, Califórnia. Já no Brasil o primeiro emissário submarino projetado foi o da praia de Ipanema, no Rio de Janeiro, em 1970, com um diâmetro da tubulação de 2,40 metros e com uma vazão de projeto igual a $12 \mathrm{~m}^{3} \cdot \mathrm{s}^{-1}$ (Gonçalves et al, op cit.)

No Brasil, existem algumas dezenas de emissários submarinos e subfluviais, onde o esgoto é apenas pré-tratado, como por exemplo, os de Ipanema, Barra da Tijuca e Rio das Ostras, no Estado do Rio de Janeiro, o de Fortaleza, Ceará, e os dois de Maceió, em Alagoas, Aracaju (Sergipe), Salvador (Bahia), Vitória (Espírito Santo), e São Sebastião, Ilha Bela, Guarujá, Santos, São Vicente e Praia Grande, em São Paulo (Gonçalves et al., op cit.).

Para o cálculo da diluição, da dispersão e do decaimento bacteriano ou químico são utilizados modelos matemáticos e, eventualmente, em lançamentos de efluentes industriais, com grandes vazões, como o de uma usina nuclear, também, modelos físicos (Marcellino, 2000).

Contudo, a água do mar nunca se mantém em um estado de equilíbrio em sua contínua interação com a atmosfera. Em outras palavras, os efeitos 
oceanográficos refletem as condições metereológicas, e dessa forma, os dados para tal modelo matemático só poderiam ser estabelecidos de modo confiável após várias medidas que cobririam todas as condições do clima local (Quetin \& De Rouville, 1986).

Pesquisas têm demonstrado que os emissários podem ser eficazes para a eliminação de organismos patogênicos. Contudo, estudos recentes revelaram ineficácia no processo de depuração natural, pela água do mar, do material particulado (rico em macronutrientes, e, por vezes, em metais e elementostraço), genericamente depositado na área próxima aos difusores. A incongruência deste método extendeu-se à utilização de modelos matemáticos para evidenciar a autodiluição do esgoto e a decomposição microbiana (e. $g$. Wagener et al., 1992; Carreira, 1994; Gray, 1996; Carreira \& Wagener, 1998; Gonzalez et al., 1999; Abessa et al., 2005; Teodoro, 2006; Gubitoso et al., 2008). No caso dos emissários paulistas, o efluente é tratado, de forma adicional, com cloro, para a eliminação de organismos patogênicos.

\subsection{ELEMENTOS-TRAÇO}

Mason \& Moore (1982) definiram elementos-traço os elementos que possuem concentrações inferiores a 1000 ppm ou $0,1 \%$, na composição de uma rocha ou sedimento. Já o restante da composição é denominada elementos maiores.

Os elementos-traço são encontrados, naturalmente, na superfície da Terra, e estão presentes em, praticamente, todos os reservatórios terrestres. Estes perfazem as rochas, os solos, e os sistemas aquáticos superficiais, subterrâneos e marinhos, oriundos do intemperismo das rochas.

Alguns elementos-traço são considerados essenciais (e/ou limitantes), pois contribuem positivamente para a agricultura e, eventualmente, à saúde humana, enquanto outros são considerados tóxicos. Entretanto, mesmo os essenciais, podem, sob condições específicas, causar impactos negativos a ecossistemas terrestres e aquáticos, constituindo, assim, contaminantes ou poluentes do solo e da água (Kennish, 1992; Baird, 1999).

O aumento na concentração de elementos-traço, no meio, pode advir tanto de processos naturais quanto de atividades antrópicas. As principais fontes 
humanas estão associadas, principalmente, a indústrias (de uma maneira geral), mineração, pesticidas utilizados na agricultura e esgotos domésticos e industriais (Brown, 1987; Siegel, 2002).

Já em águas marinhas, Goldberg (1974) classificou cinco fontes de enriquecimento natural de elementos-traço: litogênica - produtos resultantes de intemperismo de rochas das áreas fontes; hidrogênica - partículas resultantes dos produtos da precipitação de substâncias adsorvidas, formadas devido às variações físico-químicas na água do mar; biogênica - produtos da decomposição de substâncias orgânicas; atmogênica: enriquecimento proveniente da contribuição atmosférica; e cosmogênica - partículas extra-terrestres.

Segundo Soares (1992), quando os elementos-traço entram em um ambiente aquático, eles, normalmente, se incorporam a um ciclo biogeoquímico, composto por cinco reservatórios, dentre estes, quatro abióticos: água superficial, material em suspensão, sedimentos e água intersticial, e um reservatório biótico constituído pela fauna e flora marinhas.

O mesmo autor descreve que os mecanismos de interação entre estes reservatórios são promovidos pelo os processos de: adsorção/dessorção, solubilização, coagulação, floculação, complexação, precipitação (entre o material particulado em suspensão e os elementos-traço em solução), sedimentação e erosão (entre o material em suspensão e os sedimentos depositados no fundo), e mecanismos de diagênese (que podem prover elementos-traço à água intersticial do sedimento).

Todos esses mecanismos podem ser catalisados pela ação da biota. Neste contexto, o ciclo biogeoquímico influencia a concentração e a especiação dos elementos, ao longo do ciclo hidrogeoquímico.

A remobilização dos elementos-traço dos sedimentos e material em suspensão, por fatores físicos, químicos e biológicos, pode predispor os íons de elementos-traço, em seus diferentes estados de oxidação, a formas reativas. Neste estado de não equilíbrio químico, esses íons podem ser potencialmente perigosos, podendo promover a bioacumulação e/ou a biomagnificação na cadeia alimentar, e, assim, resultar em distúrbios metabólicos nos seres vivos (Soares, 1992; U.S.EPA, 2000). 


\subsection{FORAMINÍFEROS}

Os foraminíferos são protozoários que podem se movimentar constantemente. Como seres unicelulares, apresentam protoplasma granuloso, com organelas, envolvido por uma carapaça (Loeblich e Tappan, 1988; Lipps, 1993). Seus pseudópodes são delgados, anastomosados e granoreticulares, e se projetam para fora da carapaça para alimentação e locomoção (Lipps, 1993).

As carapaças dos foraminíferos podem ser orgânicas, aglutinantes ou de minerais secretados (calcita, aragonita ou sílica). As orgânicas são constituídas, predominantemente, de mucopolissacarídeos. Já as aglutinantes, além das paredes de mucopolissacarídeo, incorporam partículas sedimentares (e.g. grãos de quartzo, espículas de esponjas, outras testas de foraminíferos). As calcárias são compostas por cristais de aragonita ou de calcita. Dependendo do arranjo desses cristais, as testas podem ser translúcidas (hialinas) ou opacas (porcelanáceas) (Boersma, 1978; Lipps, 1993).

A carapaça é constituída de uma ou mais câmaras, com diferentes formatos e arranjos (Boersma e Haq, 1978). As câmaras são conectadas entre si por um orifício, o "forâmen", razão pela qual foi dado o nome da ordem: Foraminiferida. Devido a esse forâmen, o protoplasma pode ocupar todas as câmaras da carapaça (Lipps, 1983). A abertura da carapaça varia de tamanho e forma, e, geralmente, acompanha o formato da câmara na qual está inserida (Boersma, 1978).

A maioria dos hialinos e alguns aglutinantes possuem poros em sua carapaça, utilizados nas trocas gasosas (Loeblich e Tappan, 1964). Na carapaça, os poros podem variar em tamanho, forma e distribuição (Boersma e Haq, 1978).

Os foraminíferos são, em sua maioria, marinhos, mas há representantes de água doce e salobra (Cushman, 1950; Loeblich e Tappan, 1964). São encontrados em todas as latitudes (Loeblich e Tappan, 1964), desde os pólos até regiões tropicais, e desde a região de entre-marés até as abissais (Lipps, 1993).

Estes organismos podem ser bentônicos ou planctônicos. Os primeiros bentônicos surgiram há 550 milhões de anos, e, portanto, evoluíram e se difundiram desde o Cambriano até o Holoceno (Loeblich e Tappan, 1964; Boersma, 1978). Possuem representantes na infauna e na epifauna, vivendo 
entre grãos de areia, ao longo da coluna sedimentar, ou aderidos, permanente ou temporariamente, a substratos (Loeblich e Tappan, 1964).

Os planctônicos datam do Jurássico, há 190 milhões de anos, tornando-se mais abundante a partir do Cretáceo. Predominam em ambientes marinhos de águas limpas, oceânicas e sem material em suspensão, e são raros águas costeiras e rasas. (Debenay et al., 1996).

As classificações sistemáticas dos foraminíferos não são estáticas, e mudam de acordo com a atualização do conhecimento sobre o táxon. Durantes os últimos 150 anos, foram propostas 26 classificações. A composição e a morfologia das carapaças são os critérios taxonômicos mais usados para a identificação, a descrição e a classificação dos táxons (Lipps, 1993). Segundo a classificação sistemática proposta por Loeblich e Tappan (1988), os foraminíferos pertencem ao Reino Protista, Filo Granuloreticulosa, Classe Rhizopoda e Ordem Foraminifera. Dentro dessa Ordem, os autores descreveram 12 subordens, sendo que Textulariina (aglutinantes), Rotaliina (hialinos) e Miliolina (porcelanáceos), compreendem os táxons de maior diversidade biológica.

Na Paleontologia os foraminíferos são amplamente usados como fósseis guia e como bioindicadores paleoambientais (Boersma, 1978). Mas a partir da década de 1960, tiveram início trabalhos que fizeram uso deste táxon em estudos de impacto ambiental relacionados à poluição costeira (Resig, 1960; Watkins, 1961).

Os foraminíferos foram considerados, a partir de então, excelentes bioindicadores de poluição, uma vez que, dentre outros motivos: 1) possuem ciclo de vida curto, nichos determinados e respondem rapidamente a mudança ambiental; 2) incorporam elementos-traço do meio em suas carapaças; 3) são amplamente distribuídos e de caráter endêmico; 4) apresentam elevada diversidade biológica; 5) são pequenos e abundantes; 6) sua amostragem causa impacto mínimo no ambiente (Yanko et al. 1994, 1998, 1999; Duleba et al., 2005).

Estes organismos são sensíveis a muitas variáveis físicas (e.g. temperatura, luz, corrente), químicas (e.g. salinidade, alcalinidade, densidade) e biológicas (e.g. nutrientes e simbiose) no meio em que vivem. Deste modo, podem refletir as condições ambientais do microhabitat na área amostrada. (Boersma, 1978; Scott et al., 2001). 
Recentemente, tem sido explorada a possibilidade do uso de elementostraço, contidos nas carapaças de foraminíferos bentônicos calcários, como traçador de qualidade ambiental (Romano et al., 2008; Frontalini et al., 2009). Estes estudos contemplaram características ecológicas de comunidades (e.g. índices de diversidade e abundância) como indicadores ambientais de impactos por elementos-traço. Por outro lado, não há registros de estudos que consideram as características intrínsecas nas populações (e.g. concentração de elementostraço nas carapaças de foraminíferos mortos e vivos) como indicadores de impactos no meio.

\subsubsection{Ammonia tepida}

Estudos taxonômicos sobre o gênero Ammonia revelaram que a identificação de suas espécies serve como subsídio para um entendimento mais detalhado dos aspectos biogeográficos e ecológicos a elas atrelados. As identificações mais recentes das espécies de Ammonia jazem na combinação de características moleculares e morfológicas. Estes novos métodos de identificação (e.g. Holzmann \& Pawlowski, 2000) revelaram incongruências com os antigos estudos taxonômicos (e.g. Cushman, 1926).

Um exemplo veemente dos resultados dos novos estudos supra descritos é a reconfiguração da distribuição geográfica e taxonômica da espécie Ammonia tepida, descrita, primeiramente, em Puerto Rico, San Juan Harbor, Baia de Miraflores, por Cushman (1926). Segundo Holzmann \& Pawlowski, 2000, embora as assinaturas genéticas das atuais espécies do gênero ainda tenham caráter preliminar, Ammonia tepida, pode ser diferenciada pela combinação das seguintes características: linha periférica pronunciadamente lobulada, tamanho pequeno, parede finamente perfurada, lado espiral convexo, ausência de ornamentação umbilical e fissuras suturais, e ausência de pontas internas de terminação brusca, recurvadas e irregulares dos finais das câmaras.

Não obstante a ocorrência de $A$. tepida tenha sido registrada em ambientes estuarinos e costeiros, observações morfológicas e de seqüenciamento de DNA, em populações de vários locais, sugeriram que este morfotipo tem distribuição tropical e equatorial, e que, portanto, os registros dos 
habitats mais temperados são atribuídos a outros tipos moleculares de morfologias ligeiramente diferentes (Hayward, et al., 1999).

A. tepida é uma espécie euribionte, adaptadas a grandes variações ambientais, como por exemplo, profundidade, salinidade, temperatura, granulometria, pH, nível de oxigênio, entre outros parâmetros (Bradshaw, 1961; Murray, 1991; Kitazato, 1994).

$\mathrm{Na}$ faixa de $\mathrm{pH} 2,0$, ela pode sobreviver por um período de 25 minutos a 1 hora e 15 minutos (Bradshaw, 1961). Esta espécie pode sobreviver em ambientes marinhos dióxico e micróxico durante um período de 1 a 2 meses (Kitazato, 1994); em incubação anóxica pode perdurar, pelo menos, por 24 horas, indicando capacidade de metabolismo anaeróbio facultativo (Bradshaw, 1961).

Sendo ela capaz de sobreviver em condições de extremas variações ambientais e devido ao declínio das espécies estenobióticas, tem sido descrita, na literatura, como espécie dominante em áreas impactadas por atividades antrópicas. Além disso, Ammonia tepida é relatada como espécie predominante em áreas próximas a descargas de esgotos, metais pesados, poluição química e térmica, fertilizantes, soda cáustica, organo-clorados e hidrocarbonetos (e.g. Seiglie, 1968; Alve, 1991, 1995; Yanko et al., 1994; Cearreta et al., 2002; Vilela et al., 2004; Le Cadre \& Debenay, 2006).

Contudo, o uso de $A$. tepida como bioindicador de poluição deve ser cauteloso. Segundo Alve (1995) uma alta abundância de uma espécie em uma área atingida por determinado efluente, não implica, necessariamente, que ela é a espécie mais tolerante. No entanto, ela pode ser a mais bem sucedida oportunista, com alta taxa de natalidade e capacidade de colonizar rapidamente uma área perturbada, independentemente do tipo de contaminante. Entretanto, a dominância absoluta de poucas espécies, neste caso, apenas $A$. tepida é típica de estresse ambiental. 


\section{OBJETIVOS}

\subsection{OBJETIVOS GERAIS}

Avaliar a influência de efluentes domésticos e petroquímicos, dispostos por via de emissário submarino, nas composições físico-química e microbiológica da coluna d'água, geoquímica dos sedimentos e das carapaças do foraminífero $A$. tepida, no entorno dos emissários submarinos de esgoto do Araçá e do TEBAR, Canal de São Sebastião, SP.

\subsection{OBJETIVOS ESPECÍFICOS}

1) Investigar o possível impacto do efluente lançado através do emissário para o mar, por meio do estudo da qualidade da água na região próxima aos difusores do emissário, a partir dos dados físico-químicos e patogênicos.

2) Averiguar o impacto do lançamento de efluentes por meio do enriquecimento de C, N, S e P nos sedimentos;

3) Verificar a origem da matéria orgânica e potencial oxi-redutor dos sedimentos por meio das razões C/N e C/S;

4) Investigar uma possível relação entre o meio e a composição das carapaças do foraminífero $A$. tepida, por meio da quantificação de alguns elementos-traço em suas carapaças e sua correlação com os metais e os elementos-traço no sedimento. 


\section{4. ÁREA DE ESTUDO}

\subsection{DESCRIÇÃO FISIOGRÁFICA}

O Canal de São Sebastião, localiza-se entre as latitudes $23^{\circ} 40^{\prime}$ S e $23^{\circ}$ 53.5' S e as longitudes $45^{\circ} 19^{\prime}$ e $45^{\circ} 30^{\prime} \mathrm{W}$. Constitui uma feição de $25 \mathrm{~km}$ de comprimento, que separa o continente da ilha de São Sebastião (Figura 4.1A). Apresenta larguras variáveis de $2 \mathrm{~km}$, em sua porção central, e $7 \mathrm{~km}$, em suas entradas sul e norte. Seu eixo, onde estão as maiores profundidades (30 a 50 $\mathrm{m})$, está deslocado para o lado insular, devido à erosão e/ou condicionamento estrutural das rochas. As profundidades menores $(6 \mathrm{~m})$ ocorrem no lado continental do canal. As entradas sul e norte apresentam profundidades, de 25 e $20 \mathrm{~m}$, respectivamente (Figura 4.1B).

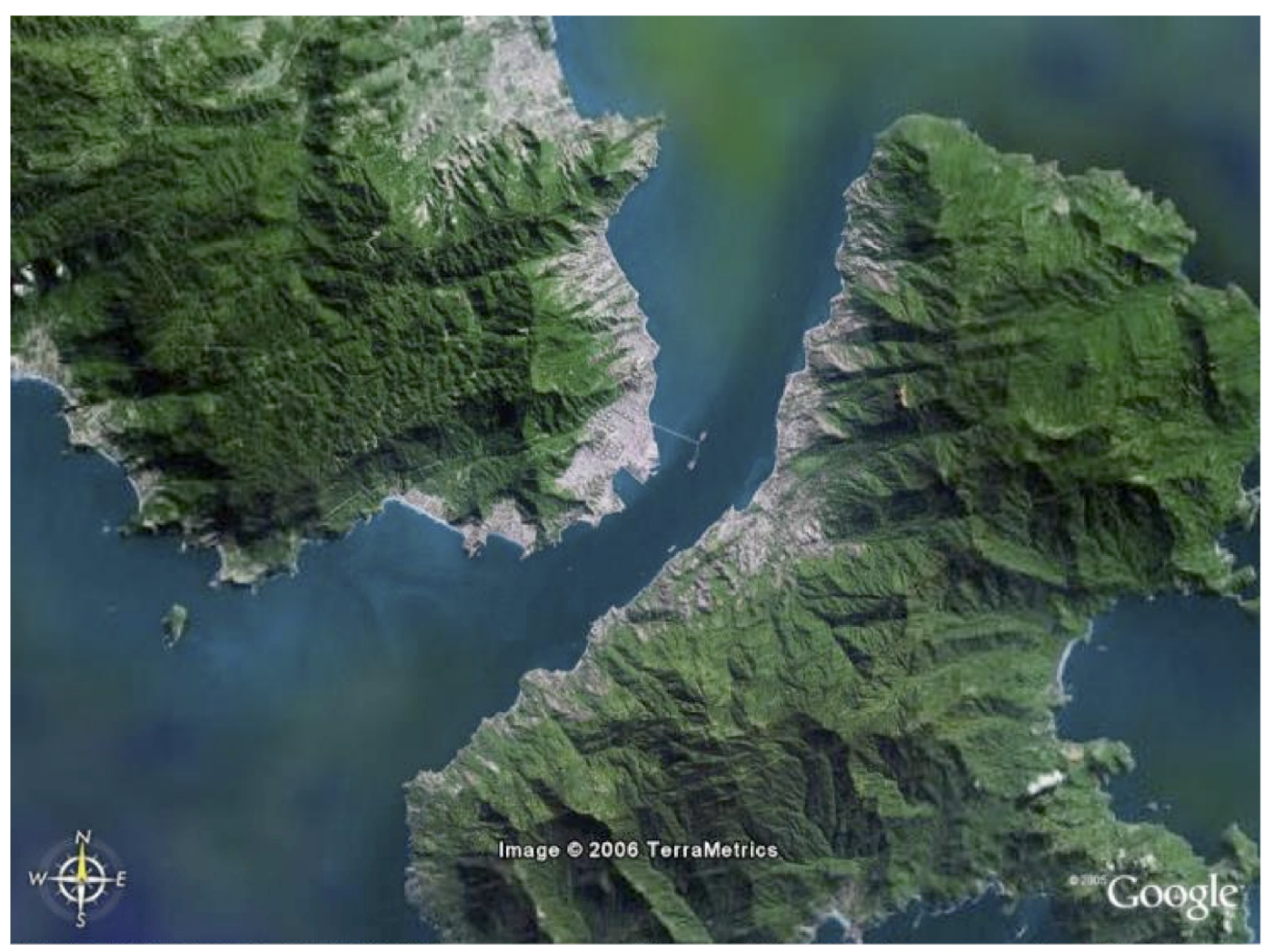

Figura 4.1A - Visão geral do Canal de São Sebastião. 


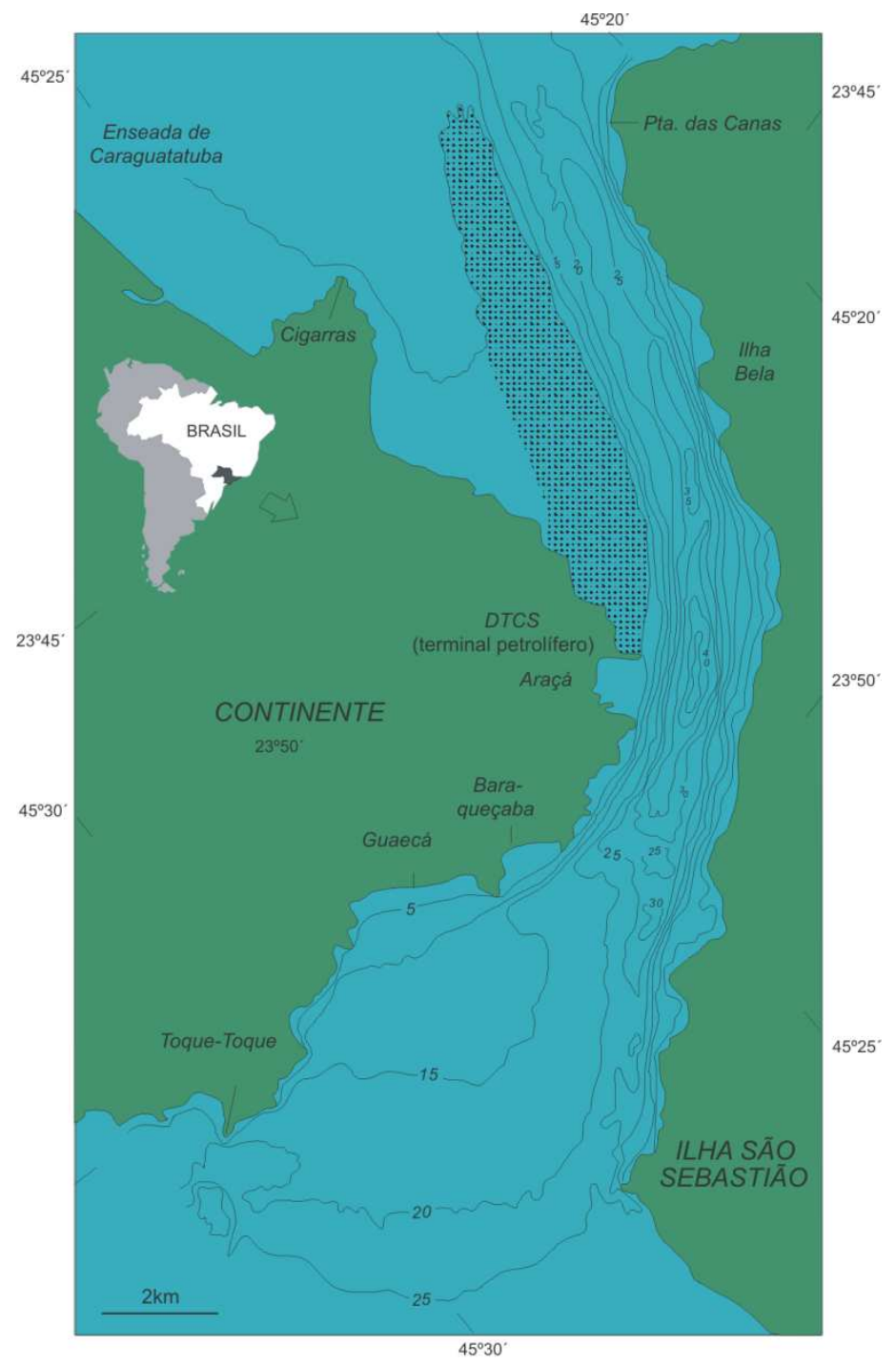

Figura 4.1B - Relevo do fundo do Canal de São Sebastião.

\subsection{CONTEXTO GEOLÓGICO}

Almeida et al. (1981) insere a região de São Sebastião no domínio tectônico denominado Maciço de Joinvile, situado a sudeste do falhamento de Cubatão. Essa região do litoral paulista é recortada pela falha transcorrente de Bertioga-Caraguatatuba, com direção SW-NE. Essa falha delimita o Bloco de São Sebastião do Bloco de Ubatuba, sendo a tectônica de formação destes, 
responsável pela formação da Serra do Mar e o relevo da costa norte paulista (Melo \& Pires Neto, 1977).

O Bloco de São Sebastião é formado por migmatitos homogêneos estromáticos do Complexo Costeiro, em que se encontram núcleos metabasíticos envolvidos por migmatitos agmatíticos, intercalações de anfibolito e um pequeno corpo de rochas granitóides. Junto à Falha Bertioga-Caraguatatuba, estas rochas estão cataclasadas em intensidade variável, ocorrendo faixas de protomilonitos, milonitos e ultramilonitos. Também se apresenta cortado por muitos diques de rochas básicas e ultrabásicas (Garda, 1995).

A ilha de São Sebastião tem sua gênese ligada à atividade vulcânica alcalina, e à reativação de falhas pré-existentes, ocorridas no sudeste brasileiro no final do Cretáceo, representadas pelo soerguimento da Serra do Mar e pela subsidência da Bacia de Santos. A ilha de São Sebastião, oriunda desses eventos magmáticos, seria remanescente do retrocesso erosivo sofrido pela Serra do Mar (Almeida, 1976). A Figura 4.2A ilustra as principais unidades litológicas encontradas na área de estudo.

O Canal de São Sebastião instalou-se em uma zona de fraqueza, abatida e propícia à erosão, entre a Ilha de São Sebastião e a Serra do Juqueriquerê. Orienta-se de acordo com as estruturas gerais da área (SW-NE), cinfigurando-se, inicialmente, como um vale produzido pelo abatimento de blocos decorrente dos sistemas de falhamaneto da Serra do Mar (Furtado et al., 2008)

Garda (1995), sugere que a concentração de diques básicos a intermediários, que se concentram paralelamente e/ou formando ângulos com o eixo do canal, indicam as zonas de fraqueza das rochas da região, evidenciando o que foi um possível rift abortado.

Para Almeida (1976), o Canal de São Sebastião teria sido escavado subaereamente durante as últimas fases glaciais do Pleistoceno. Mahiques et al. (1989), por sua vez, relacionaram também as depressões alongadas e profundas, presentes no interior do canal, a processos de escavação por marés, ocorridos durante o evento transgressivo holocênico, cujo máximo ocorreu há cerca de 5.100 anos A. P.

A distribuição de sedimentos ao longo do canal está relacionada a geometria, topografia de fundo e circulação local. A geometria do canal, mais especificamente sua curvatura, assemelha-se a um canal fluvial, apresentando margens deposicional (lado continental) e erosiva (lado insular). A topografia do 
canal é extremamente irregular, com grandes variações em pequeno espaço, produzindo uma distribuição dos sedimentos em manchas, com tamanhos variados (Furtado, 1995; Barcellos \& Furtado, 1999, 2001).

O litoral norte é caracterizado pelo processo de submersão costeira, responsável pelo afogamento e formação das enseadas e costões. A partir de Maresias, caracteriza-se por uma sedimentação restrita a pequenas reentrâncias da costa e pela existência de importantes paredões rochosos mergulhando diretamente no mar (Chieregati et al., 1982).

Dentre essas reentrâncias cita-se a Baía do Araçá, situada no lado continental do canal (Figuras 4.2B), sendo uma enseada artificial formada durante a construção do porto de São Sebastião em 1936 (Conselho de Autoridade Portuária - CAP, 2009). Apresenta profundidades máximas de $10 \mathrm{~m}$ em sua desembocadura e, rumo ao continente, a enseada torna-se mais estreita e rasa. Possui algumas ilhotas distribuídas em seu interior e três pequenas praias: Pernambuco, Germano e Topo. 


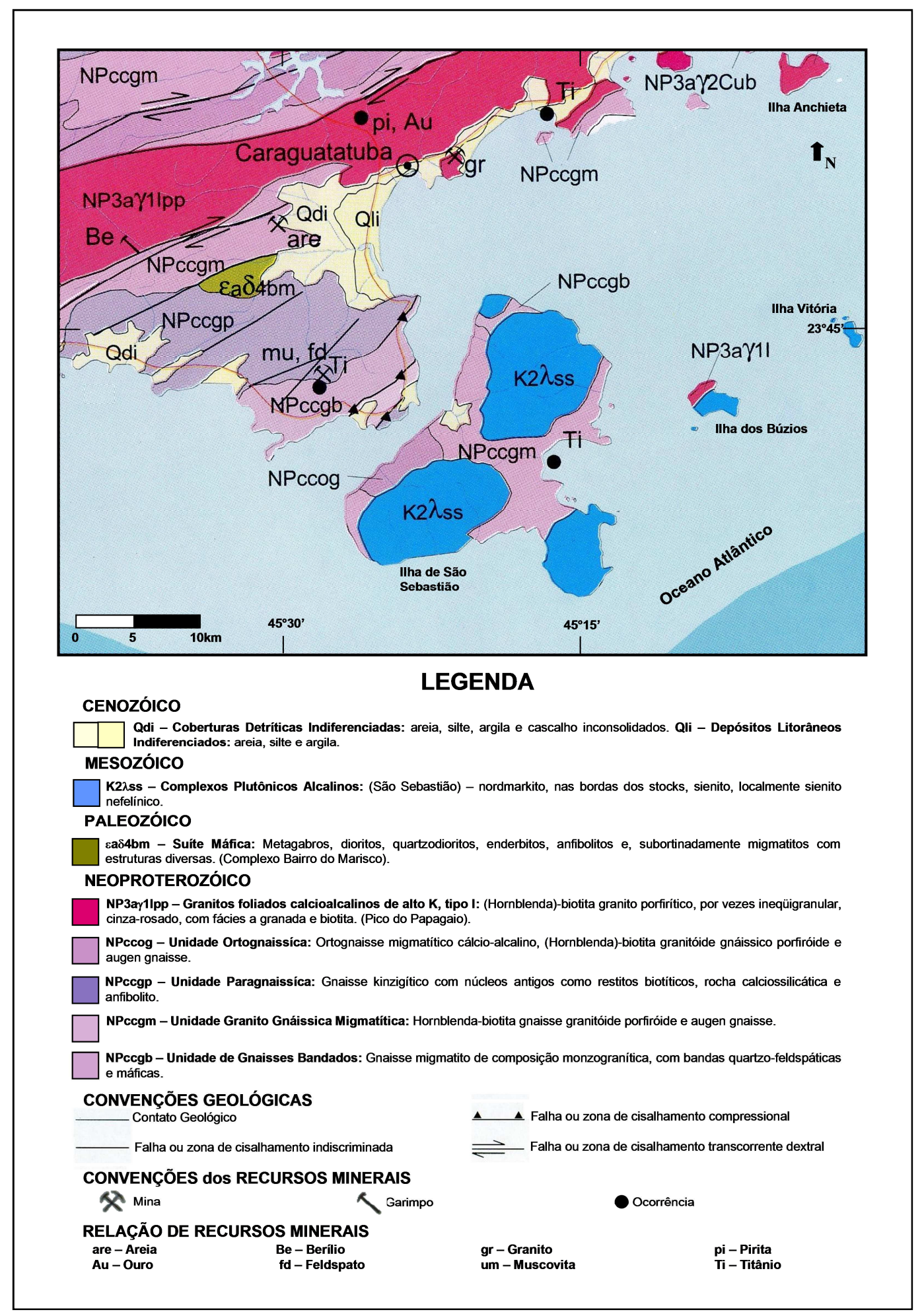

Figura 4.2A - Mapa geológico da região de estudo. (modificado de CPRM, 2005) 


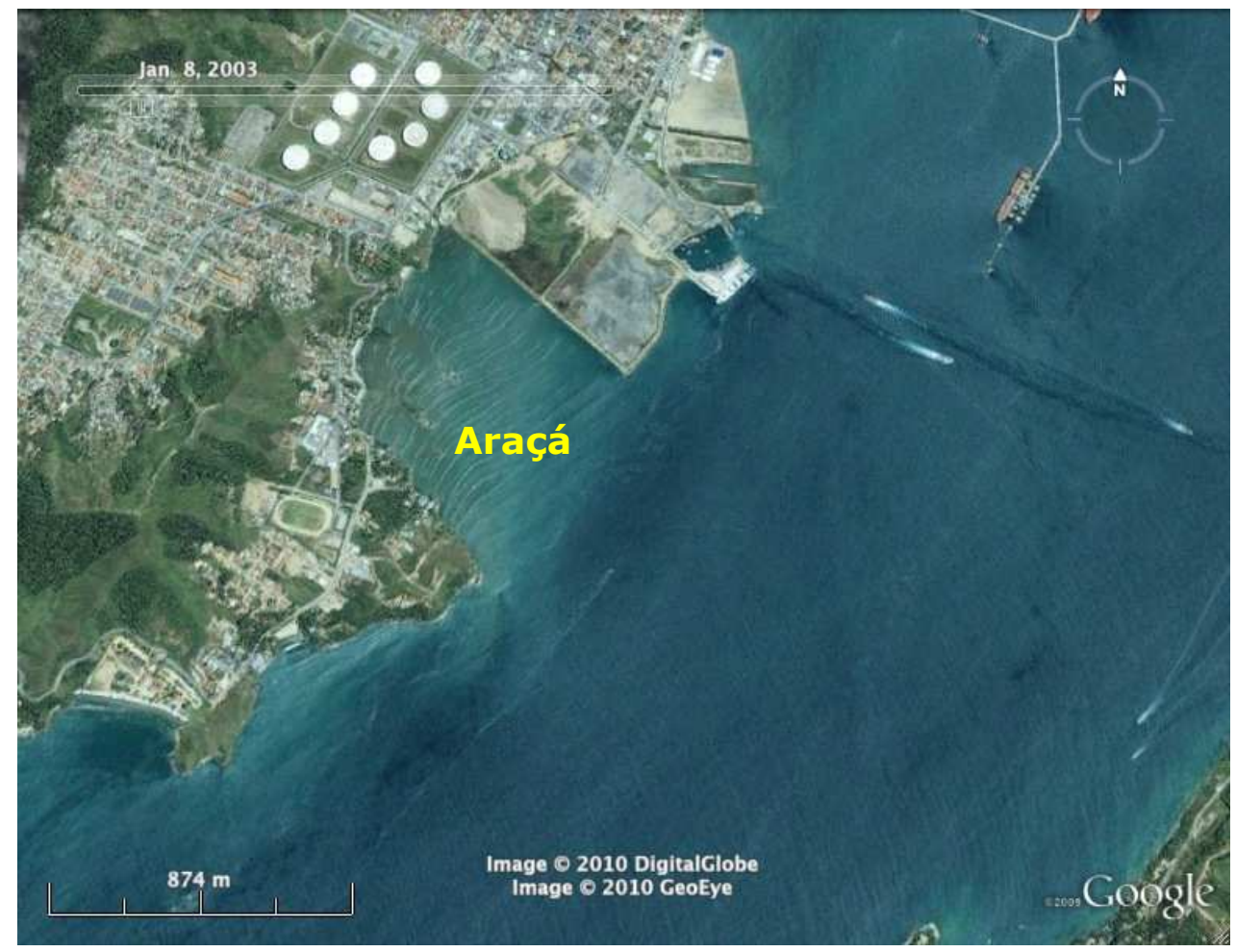

Figura 4.2B -Baía do Araçá.

\subsection{CARACTERIZAÇÃO OCEANOGRÁFICA}

A circulação do canal caracteriza-se por movimentos para norte e sul, com periodicidade de dias, pouco influenciados pelas correntes de maré (Castro-Filho, 1990; Fontes, 1995; Miranda \& Castro-Filho, 1995). A geometria e a topografia do fundo do canal condicionam correntes mais intensas no sentido longitudinal do lado insular, com velocidades de até $1,0 \mathrm{~m} \mathrm{~s}^{-1}$ para o norte e $0,7 \mathrm{~m} \mathrm{~s}^{-1}$ para sul (FUNDESPA, 1999). As características termohalinas do canal são determinadas pelo transporte de massas de água da plataforma continental, cujos movimentos são, predominantemente, gerados pelo vento e por forças de gradiente de pressão. 


\subsection{INFLUÊNCIA ANTRÓPICA}

No Canal de São Sebastião, há algumas áreas onde a influência antrópica é bastante acentuada. Dentre estas, cita-se a região central do canal, onde está instalado um dos maiores terminais petrolíferos do Brasil, o Terminal Petrolífero Almirante Barroso (TEBAR) da companhia Petróleo Brasileiro S.A. (PETROBRAS) (Figura 4.4). O TEBAR serve como importador e entreposto de petróleo e derivados. Este terminal recebe, armazena e transfere petróleo para posterior tratamento nas refinarias de Paulínia, Cubatão, Capuava e São José dos Campos, SP. Além disso, transfere petróleo bruto destinado à exportação e abastecimento de outras refinarias nacionais (Neiva, 1993). O terminal é constituído de um oleoduto que interliga um conjunto de 40 tanques de armazenamento, na parte terrestre, a duas plataformas, situadas no meio do Canal de São Sebastião, i.e. a aproximadamente $1 \mathrm{~km}$ da costa.

O TEBAR, além do píer de atracação de navios, possui tanques para armazenamento de petróleo e seus derivados (gasolina, óleo diesel, nafta e querosene de aviação, metanol e lastro). Cada píer possui dois berços de atracação, podendo operar até quatro navios simultaneamente. Os estudos para a instalação de um terminal marítimo em São Sebastião tiveram início em 1957, como alternativa para abastecimento de petróleo à Refinaria de Cubatão, SP. Em 1961, a PETROBRAS foi autorizada a construí-lo no Canal de São Sebastião. Em 1968, ocorreu a primeira descarga de petróleo, e em 11 de abril de 1969 foi inaugurado o TEBAR. Já em março de 1992 foram criados os Dutos e Terminais do Centro-Sul (DTCS), do qual o terminal passou a fazer parte como unidade operacional. Há três anos, a unidade passou a integrar a Gerência de Terminais Aquaviários da Transpetro.

Próximo ao TEBAR há o Porto de São Sebastião, para navios de pequeno e médio calado e um emissário submarino (Araçá), que transporta quase todo esgoto doméstico da cidade de São Sebastião. O canal tem mais dois outros emissários de pequeno porte, localizados em Cigarras e no Saco da Capela. 


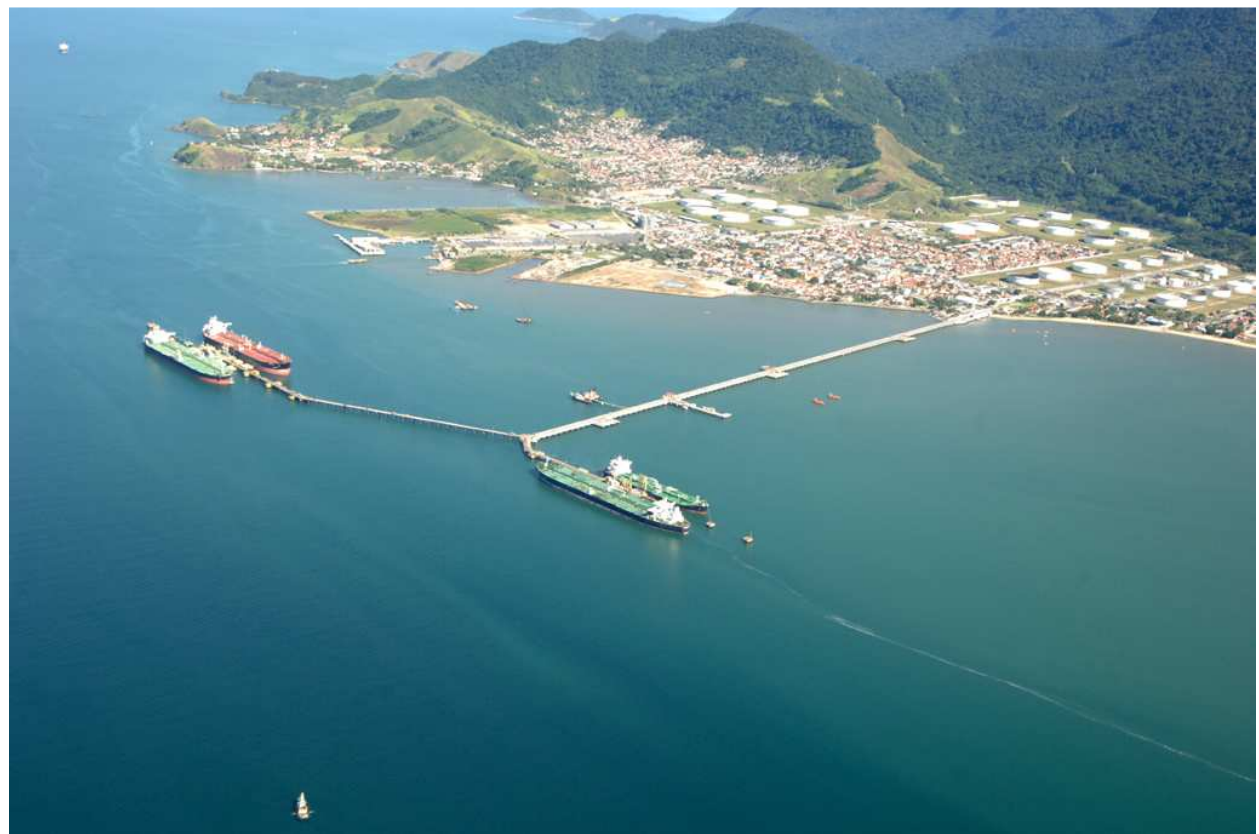

Figura 4.4 - Terminal Petrolífero Almirante Barroso (TEBAR).

\subsection{CARACTERÍSTICAS TÉCNICAS DOS EFLUENTES E DOS EMISSÁRIOS 4.5.1 O Araçá}

Os efluentes domésticos, captados pela rede sanitária de São Sebastião, são tratados apenas em estações de pré-condicionamento, onde passam por: 1) grades, para remoção de sólidos grossos e flutuantes (gradeamento); 2) peneiras, para remoção de sólidos finos ou fibrosos (peneiramento); 3) caixas de areia ou dearenadores (Marcellino, 2000). Posteriormente, os efluentes são desinfectados por cloração e lançados ao mar por via de emissário submarino, localizado na baía do Araçá (Figura 4.5.1).

O emissário submarino do Araçá, construído pela SABESP, entrou em operação em 1990 e atende a uma população máxima de 21.396 pessoas. É composto por duas partes: terrestre, construída em tubos de ferro fundido, com diâmetro de 400mm e extensão de 3.800m, e submarina, constituída por tubulação de polietileno de alta densidade (PEAD) com diâmetro de $400 \mathrm{~mm}$, extensão de $1090 \mathrm{~m}$ e com vazão de $0,14 \mathrm{~L} \mathrm{~s}^{-1}$ (CETESB, 2005). A tubulação submarina é guarnecida de blocos de ancoragem de concreto para garantir seu posicionamento no leito marinho. Em sua extremidade terminal, o tubo é munido de um trecho difusor com $10 \mathrm{~m}$ de comprimento com 17 orifícios (CETESB, 2005). Este emissário submarino tem seu início na praia do Topo e sua 
extremidade final, junto à Ponta do Araçá, com os seus difusores situados a aproximadamente $7 \mathrm{~m}$ de profundidade.

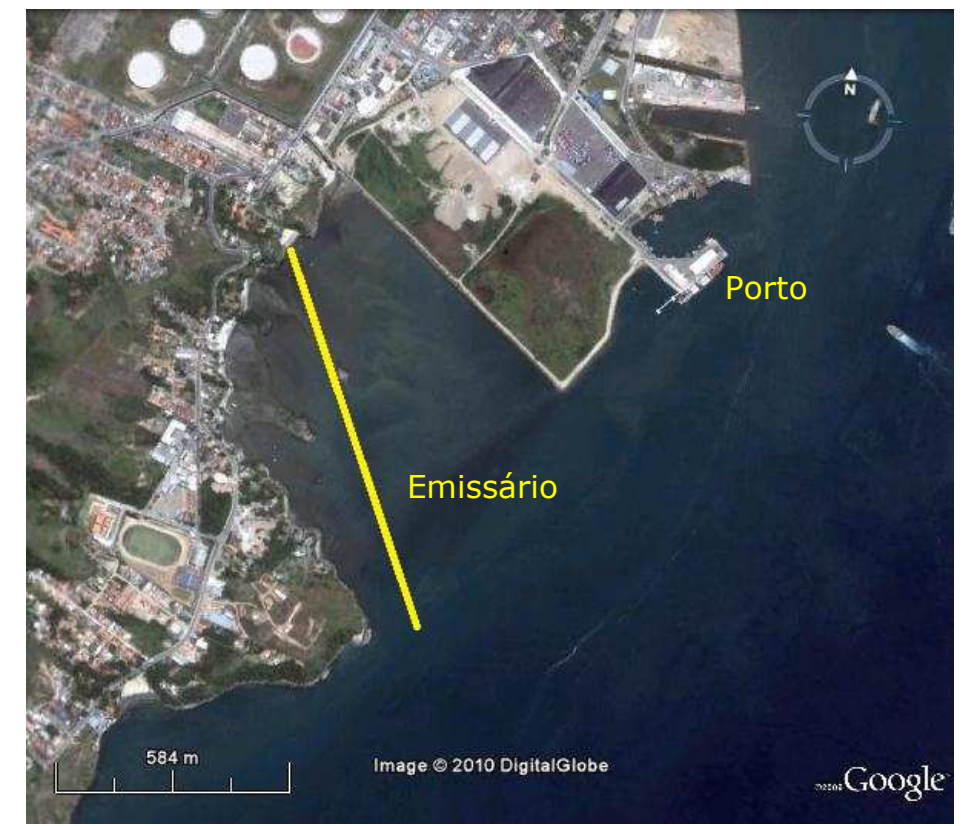

Figura 4.5.1 - Esquema de localização do emissário submarino de esgoto do Araçá.

\subsubsection{O Terminal Petrolífero Almirante Barroso (TEBAR)}

Segundo Fortis (2005), o terminal lança, via de emissário submarino, efluentes provinentes dos sistemas Separadores de Água e Óleo (SAO) e da Estação de tratamento de Efluentes (ETE). Esses efluentes, na grande maioria, são oriundos da mistura de água de produção e petróleo dos navios, das águas de drenagem dos tanques de armazenamento, das águas pluviais e de incêndios e por fim dos vazamentos de tipo oleosos.

Os efluentes são encaminhados para duas linhas: linhas 1 e 2 para serem direcionados para ETE e SAO. Na linha 1 são efluentes gerados na drenagem dos fundos dos tanques e dos navios atracadas no terminal aquaviário, contendo águas de produção e óleo. Na linha 2 são as águas pluviais e industriais contaminadas com óleo (águas de incêndio, vazamento de válvulas, etc.)

Os efluentes do tipo 1 , linha 1 , recebem tratamento físico-químico na ETE, com as etapas de flotação (para retirada do óleo livre) e de adição de peróxido de hidrogênio, de ácido sulfúrico e de soda cáustica (para oxidação do sulfeto e 
do fenol). Os despejos do tipo 2, linha 2, são tratados por diferença de densidade nos chamados Sistemas de Separação de Águas Oleosas (SAO). Posteriormente, estes dois tipos de efluente são misturados, antes de serem enviados para o emissário (Figura 4.5.2).

Dentre as várias vistorias realizadas à ETE do TEBAR pela CETESB, foram constatadas concentrações anômalas de alguns elementos químicos, como Ba e Bo, nos efluentes. Diante disso, a partir de 2009, com o Termo de Ajuste de Conduta (TAC), foi implementado um novo sistema de tratamento de água de produção, capaz de enquadrar os efluente aos limites legais .

Em relação ao o emissário do TEBAR, sua constituição é de Polietileno de Alta Densidade (PEAD) e apresenta $3.000 \mathrm{~m}$ de extensão. É dividido em linhas sul $(1.600 \mathrm{~m})$ e norte $(1.400 \mathrm{~m})$. No final de cada emissário, há uma seção difusora com 3 tubos verticais (risers) com 1,5 m e diâmetro de 0,15 m, cada um, voltados para a superfície. A vazão máxima deste emissário é de $0,208 \mathrm{~m}^{3} \mathrm{~s}^{-}$ 1.

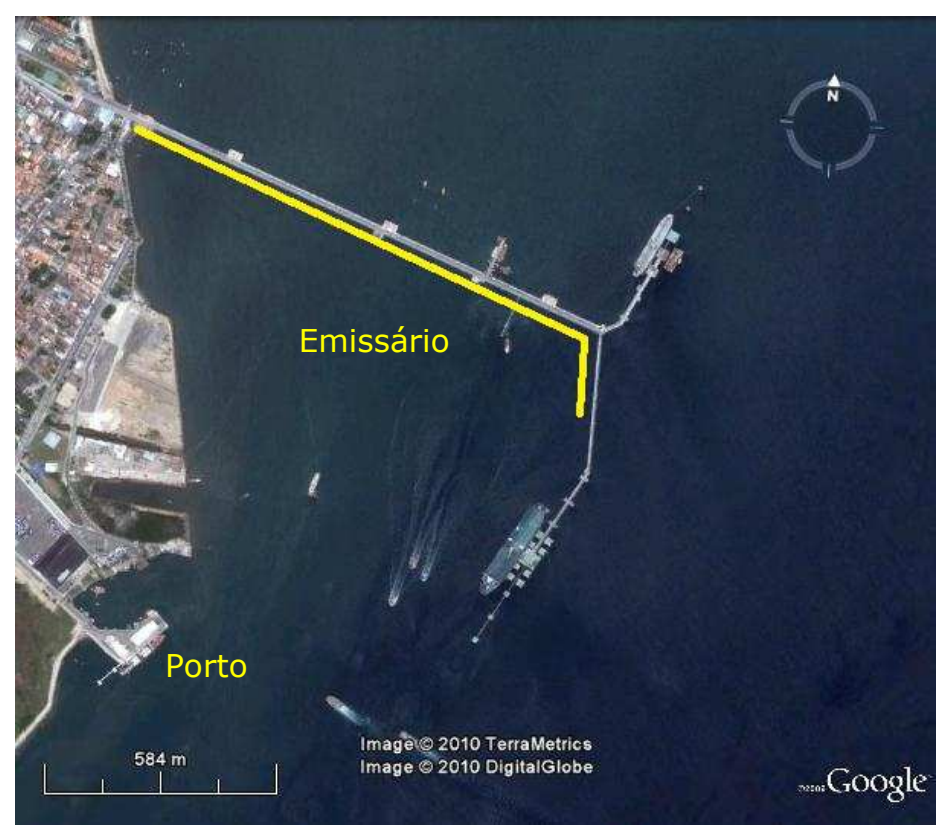

Figura 4.5.2 - Esquema de localização do emissário submarino de esgoto do TEBAR. 


\section{MATERIAIS E MÉTODOS}

\subsection{PROCEDÊNCIA DAS AMOSTRAS}

Os sedimentos utilizados para este estudo foram coletados em conjunto com a CETESB, durante a campanha de verão de 2007 (março e abril). Foi utilizada rede amostral do tipo círculo crescente, com 10 pontos de coleta, em área de influência direta do efluente (i.e., nas proximidades dos difusores) (Figuras 5.1A e 5.1B). Foi também coletado sedimento de um ponto, localizado distante dos dois emissários, para ser referência de valores (background), i.e. ponto controle (Figura 5.1C). Essas coletas foram realizadas antes do novo sistema de tratamento de águas de produção.

Em cada ponto amostral dos emissários foi realizada a medição dos seguintes parâmetros físico-químicos: profundidade, temperatura, salinidade (CTD Seacat), oxigênio dissolvido, pH (potenciômetro Beckman Zeromatic II). Também foram coletadas amostras de água na superfície, no meio e no fundo da coluna de água, para análise de nutrientes dissolvidos (nitrogênio amoniacal, nitrogênio Kjeldahl total, fósforo total, ortofosfato), dos teores de fenol total, óleo, graxas, enterococos e coliformes fecais. As análises dos parâmetros físicoquímicos e microbiológicos foram realizados e fornecidos pela CETESB.

Esses dados foram comparados com os limites reguladores das resoluções federais CONAMA (Conselho Nacional do Meio Ambiente) $n^{\circ}$ 20/1986 e $n^{\circ}$ 357/2005. Estas legislações estão relacionada à qualidade das águas litorâneas e embora não específica para controle dos lançamentos de emissários, têm sido instrumento importante para avaliação e controle desses sistemas, bem como da qualidade ambiental das águas marinhas. 


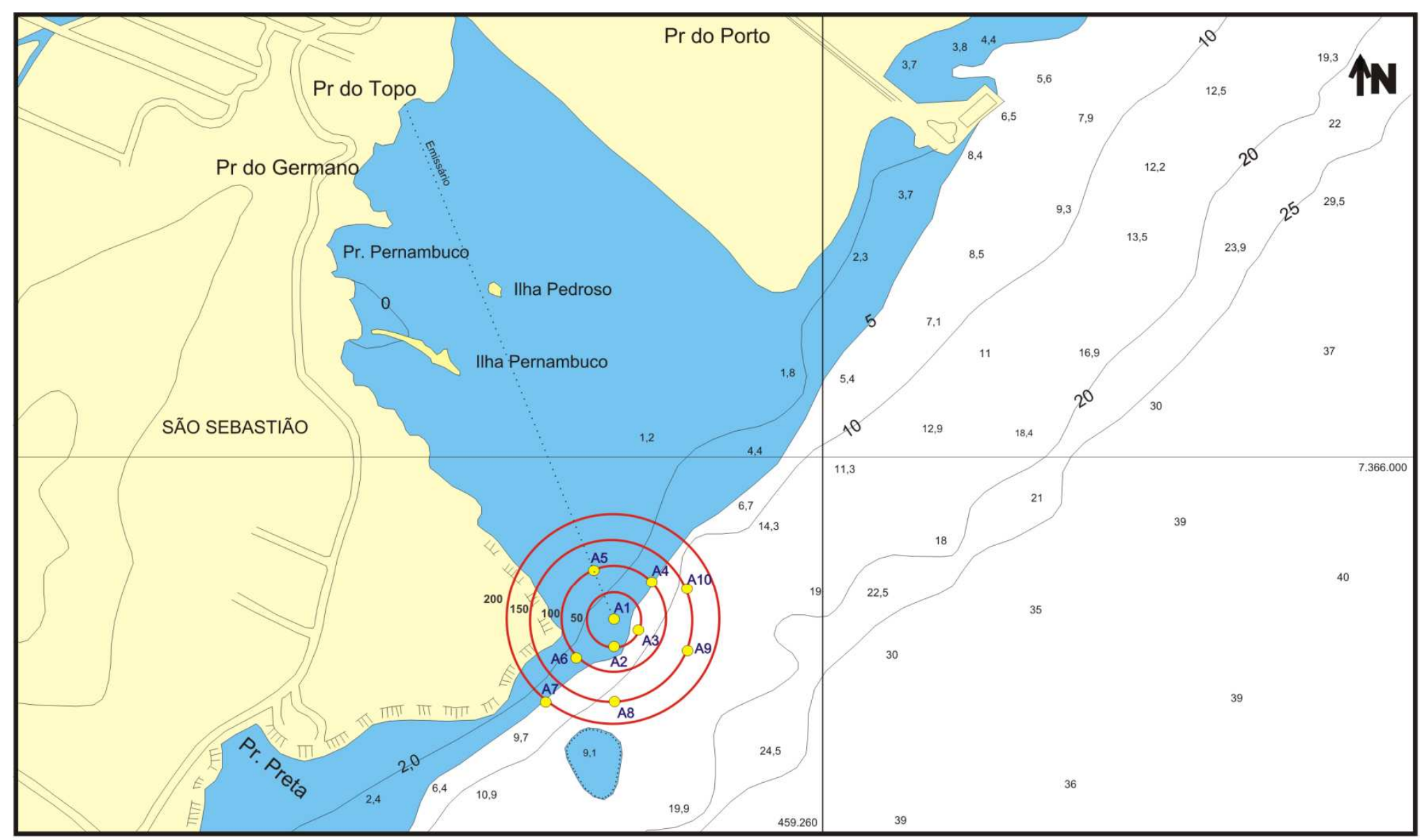

LOCALIZAÇÃO DOS PONTOS DE AMOSTRAGEM ARAÇÁ

MUNICÍPIO DE
SÃO SEBASTIÃO
Legenda
$\square$ Município
Oceano até isóbata de 5m
$\square$ Oceano após isóbata de 5m
Ponto de Amostragem
COORDENADAS EM UTM
DATUM SAD 69
\[ \begin{array}{c}200 \mathrm{~m} \\ 0\end{array} \]

FONTE: CARTA NÁUTICA (No 1643) - CANAL DE SÃO SEBASTIÃO (PARTE NORTE). PUBLICAÇÃO DA SEGUNDA EDIÇÃO, NO RIO DE JANEIRO, EM 2003

Figura 5.1A - Rede amostral na área de influência do emissário do Araçá. 


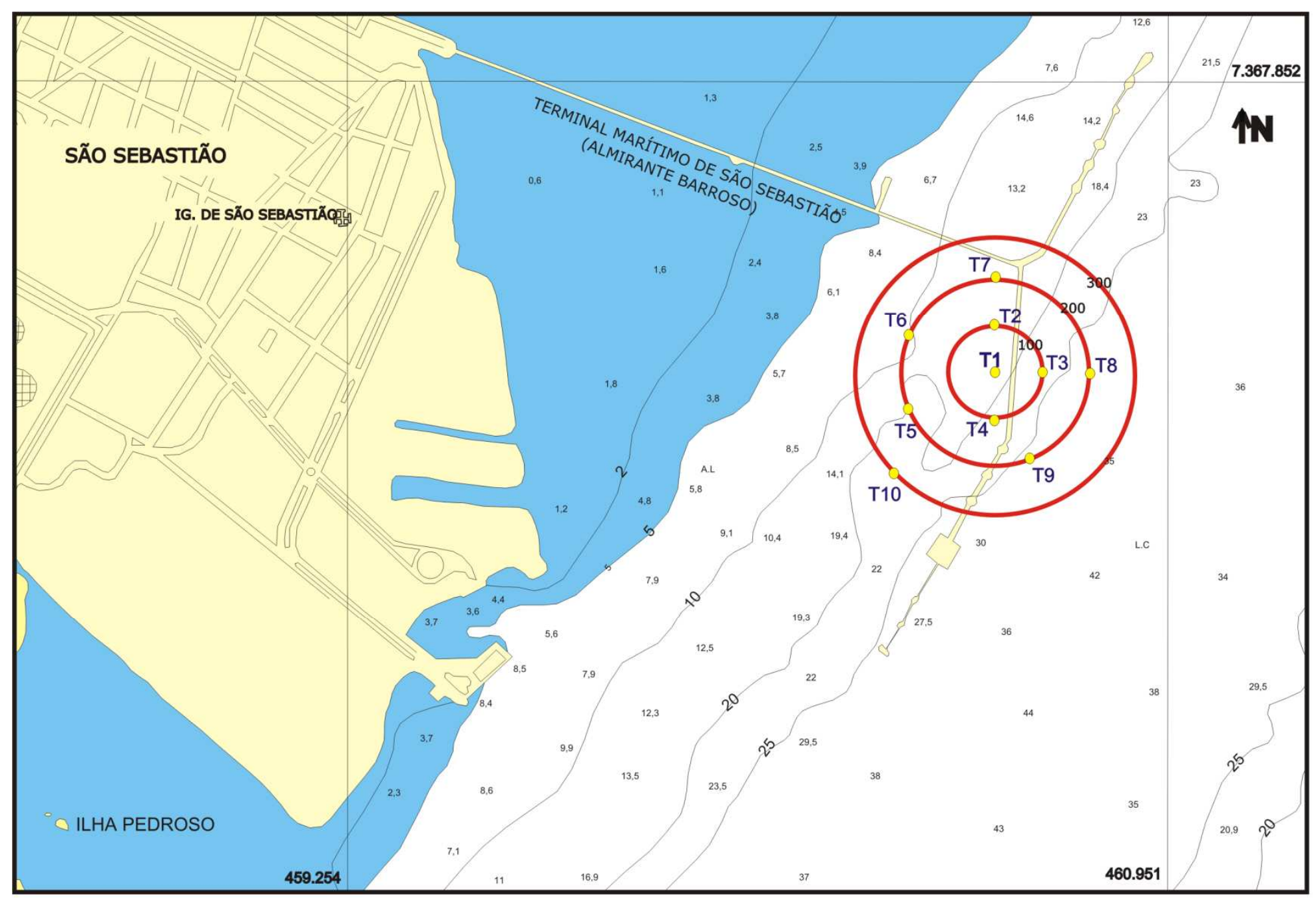

LOCALIZAÇÃO DOS PONTOS DE AMOSTRAGEM TEBAR

MUNICÍPIO DE SÃO SEBASTIÃO

Legenda

Município

Oceano até isóbata de $5 \mathrm{~m}$

Oceano após isóbata de $5 \mathrm{~m}$

- Ponto de Amostragem

COORDENADAS EM UTM DATUM SAD 69

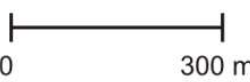

FONTE: CARTA NÁUTICA (No 1643) - CANAL DE SÃO SEBASTIÃO (PARTE NORTE). PUBLICAÇ̃̃O DA SEGUNDA EDIÇÃO, NO RIO DE JANEIRO, EM 2003.

Figura 5.1B - Rede amostral na área de influência do emissário do TEBAR. 


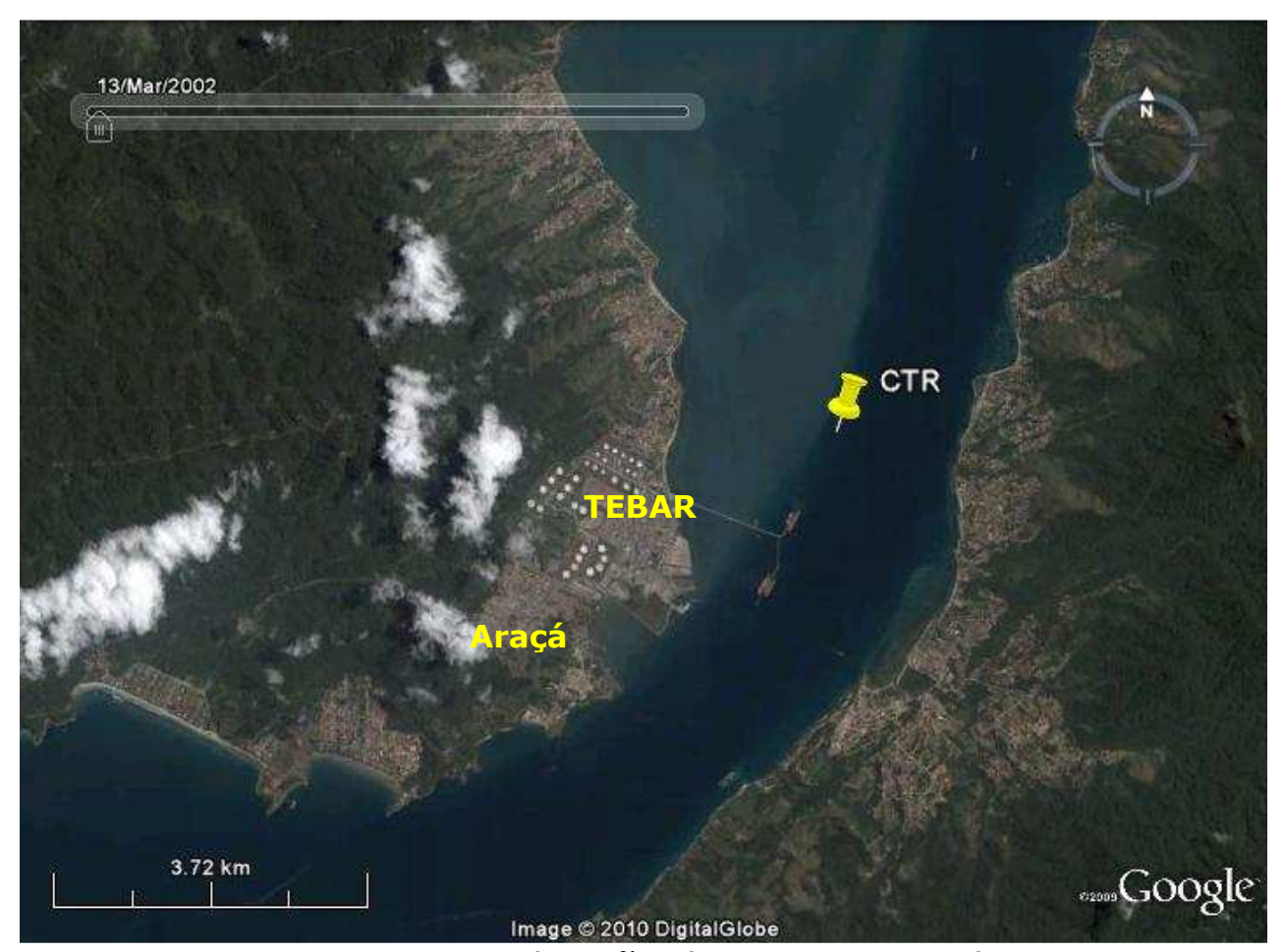

Figura 5.1C - Localização do ponto controle CTR.

Obs.: Coordenadas do ponto CTR: Lat $-23,792441$ Long $-45,379643$ 


\subsection{ANÁLISES SEDIMENTOLÓGICAS}

No mesmo local da amostragem hidrográfica foram coletadas amostras de sedimento de fundo, com pegador de mandíbula tipo Petersen, as quais foram divididas em três partes distintas: para análises granulométricas, geoquímicas e do conteúdo de foraminíferos. O sedimento utilizado para análise granulométrica, foi seco em estufa a $60{ }^{\circ} \mathrm{C}$ e encaminhado para o Laboratório de Sedimentologia do IGc-USP.

Ao sedimento destinado à análise do conteúdo de foraminífero, seguindo a metodologia de Walton (1952), foi adicionado álcool etílico com corante vital Rosa de Bengala ${ }^{1}$ para a posterior identificação dos foraminíferos vivos (i.e. os indivíduos vivos adquirem a coloração rosa devido ao tingimento do protoplasma dentro das carapaças).

A parte destinada à análise geoquímica foi congelada, com o intuito de evitar ataque bacteriano, desde a coleta até o início do processo de secagem em estufa a $60^{\circ} \mathrm{C}$. Já completamente secas, as amostras foram destinadas ao Laboratório de Preparação de Amostras do IGc-USP, onde foram peneiradas em malha de aço inoxidável de $1 \mathrm{~mm}$, pulverizadas em moinho de ágata à fração silte e quarteadas em alíquotas menores.

As alíquotas menores foram encaminhadas ao Laboratório Química do IGcUSP, ao laboratório Acme Labs Inc. e ao Centro de Estudos Químicos da UNIFIEO.

\subsubsection{Análises Granulométricas}

Foram utilizadas duas técnicas: decantação (pipetagem) para frações mais finas que $62 \mu \mathrm{m}$ (chamadas de silte e argila) e, peneiramento, para frações mais grossas que $62 \mu \mathrm{m}$ (areia e grânulos), ambas baseadas em Suguio (1973).

A primeira etapa do procedimento analítico utilizado consistiu em deixar a amostra na estufa até sua secagem completa. A segunda etapa foi a desagregação a seco, feita com uso de um martelo de borracha.

\footnotetext{
${ }^{1}$ Este corante é um derivado tetraclorado e tetraiodado da fluoresceína sódica $\left(\mathrm{C}_{20} \mathrm{H}_{2} \mathrm{Cl}_{4} \mathrm{I}_{4}\right.$ $\left.\mathrm{Na}_{2} \mathrm{O}_{5}\right)$.
} 
Depois de finalizada a desagregação, procedeu-se a subamostragem da amostra em quarteador tipo Jones, até a redução da massa a aproximadamente 60 g (massa máxima recomendada para não saturar a dispersão aquosa em $1000 \mathrm{~mL}$, nem sobrecarregar as peneiras).

Na seqüência, foi adicionada à amostra uma massa de pirofosfato de sódio, equivalente a $4 \%$ do peso estimado de partículas síltico-argilosas. Este sal age como antifloculante, evitando que a argila fique agregada sob a forma de partículas maiores, o que alteraria o resultado final de distribuição granulométrica.

Em seguida, foi adicionada água destilada em quantidade suficiente para cobrir a amostra juntamente com o pirofosfato de sódio (cerca de $200 \mathrm{~mL}$ ). A dispersão aquosa assim obtida foi, então, colocada em um béquer e homogeneizada por agitação mecânica, com o uso de um misturador de polpa à hélice (marca Fisatom, modelo 710).

O material disperso foi colocado em proveta de $1000 \mathrm{~mL}$, destinada à realização do ensaio de decantação. No caso de amostras que ainda apresentaram material aglomerado, o mesmo precisou ser desagregado em almofariz de porcelana, com o auxílio de pistilo de borracha. O material só foi considerado completamente desagregado, quando a água adicionada ao mesmo se manteve limpa.

Toda a água utilizada no processo de desagregação foi juntada à anterior na mesma proveta, tomando cuidado para que o volume de água utilizado não ultrapassasse a capacidade volumétrica do recipiente $(1000 \mathrm{~mL})$. Para cada proveta foram numerados e pesados, previamente em balança analítica (precisão mínima de três dígitos), cinco béqueres de $50 \mathrm{~mL}$, destinados a cada uma das faixas granulométricas a serem coletadas (intervalos abertos correspondentes às granulações menores que 62, 31,16, 8 e 4 mm).

Para programar os tempos de coleta de alíquotas por pipetagem, utilizouse uma tabela padrão, elaborada de acordo com a lei de decantação de partículas em fluído estacionário, sem turbulência (lei de Stokes) (Suguio, 1973). A primeira e a segunda pipetagens foram feitas com a pipeta mergulhada $20 \mathrm{~cm}$ na dispersão, enquanto as três últimas foram realizadas a $10 \mathrm{~cm}$, para reduzir o tempo total de ensaio ( $2 \mathrm{~h}$ e 30 min para temperatura ambiente de $21^{\circ} \mathrm{C}$ ).

Os béqueres, com as respectivas alíquotas de pipetagem, foram colocados em estufa a $60{ }^{\circ} \mathrm{C}$ até que a água da dispersão evaporasse completamente, 
restando apenas o resíduo seco. Após o resfriamento dos béqueres, contendo os resíduos em dessecador, efetuou-se a pesagem, anotando-se as respectivas massas na ficha de controle do ensaio.

Posteriormente, a amostra restante na proveta foi submetida à elutriação, isto é, à lavagem para eliminação de finos ( $<62 \mathrm{~mm}$ ). Este processo foi feito em um elutriador de funis utilizando água corrente em fluxo ascendente. Ao final da elutriação, a areia lavada foi filtrada a vácuo.

A areia foi, então, seca em estufa e depois peneirada com o auxílio de vibrador de peneiras. As peneiras devem obedecer à escala granulométrica de Wentworth-Krumbein (intervalos de $0,5 \varnothing$ ou $-\log _{2} d m_{m m}$, onde $d m$ é o diâmetro do grão expresso em $\mathrm{mm}$ ). Cada faixa granulométrica foi pesada e armazenada em saquinho de papel.

Os dados obtidos (massas dos recipientes vazios e com amostras pipetadas, após a secagem, e a massa da amostra em cada faixa granulométrica de peneiramento) foram digitados em planilhas eletrônicas elaboradas no Laboratório de Sedimentologia do IGcUSP, que calculam a curva acumulativa e o histograma da distribuição granulométrica.

\subsubsection{Análise Geoquímica}

5.2.2.1 Teores de carbonato de cálcio, carbono orgânico, nitrogênio total e enxofre total

O procedimento analítico para obtenção dos teores de carbonato de cálcio foi realizado por meio de ácido clorídrico a $10 \%$ e diferença de massa (Gross, 1971). A classificação dos sedimentos, segundo o conteúdo de carbonato de cálcio, foi feita de acordo com a proposição de Larssonneur et al. (1982). Segundo estes autores, sedimentos que apresentam teores inferiores a $30 \%$ de $\mathrm{CaCO}_{3}$ foram considerados litoclásticos; teores entre 30 e $50 \%$, litobioclásticos; entre 50 e $70 \%$, biolitoclásticos e sedimentos com mais de $70 \%$, bioclásticos.

Após obter os teores de carbonato, o sedimento tratado por ácido foi destinado à análise de carbono orgânico. Uma segunda porção, que não foi tratada por ácido, foi destinada à análise de nitrogênio, enxofre e fósforo total. As análises de carbono orgânico e nitrogênio foram realizadas no aparelho $\mathrm{CHN}$ 1000 da LECO $\Re$, pertencente à Central Analítica do Instituto de Química (IQ- 
USP). As análises de enxofre foram efetuadas por meio do aparelho SC-432 da LECO $®$, do Laboratório de Química do IGc-USP.

Com base nos dados de carbono orgânico, nitrogênio total e enxofre total foram calculadas as razões $\mathrm{C} / \mathrm{N}$ e $\mathrm{C} / \mathrm{S}$, que permitem fazer considerações sobre a origem da matéria orgânica e o estado redox do ambiente de deposição refletido pela redução do sulfeto na decomposição da matéria orgânica, respectivamente.

De acordo com Stein (1991), razões C/N com valores abaixo de 6 indicam matéria orgânica de origem marinha e, acima de 15 matéria orgânica de origem continental. Os valores intermediários são atribuídos a mistura de fontes marinha e continental.

Hedges \& Keil (1995) cita que valores da razão C/S entre 1,5 a 5 indicam sedimento depositado sob eventos periódicos de anoxia e coluna d'água óxica. Valores acima de 5 correspodem sedimentos e coluna d'água óxica e abaixo de 1,5 coluna d'água e sedimento anóxico.

\subsubsection{Teores de fósforo total, inorgânico e orgânico}

As análises de fósforo (total, inorgânico e orgânico) foram realizadas no Centro de Estudos Químicos da UNIFIEO. A determinação e a especiação seguiram o método proposto por Legg \& Black (1955), no qual a amostra foi dividida em duas porções, sendo uma tratada em mufla a $240{ }^{\circ} \mathrm{C}$, durante 1 hora.

As duas porções foram digeridas com alíquotas de $10 \mathrm{~mL}$ de $\mathrm{HCl}$, concentradas por 10 minutos, sob aquecimento a $70{ }^{\circ} \mathrm{C}$, e mais $10 \mathrm{~mL}$ de $\mathrm{HCl}$, por uma hora, a temperatura ambiente. Após filtração e diluição adequada com água deionizada, foi feita a determinação do fósforo, utilizando espectrofotômetro Shimadzu, modelo UV-1601 PC, acoplado a um sistema de análise por injeção em fluxo (Zagatto et. al., 1981).

Por diferença dos resultados obtidos para a porção tratada em mufla (fósforo total) e a porção não tratada (fósforo inorgânico), obteve-se a proporção de fósforo orgânico nos sedimentos. 


\subsubsection{Elementos maiores e traço}

Quanto aos teores de elementos maiores e traço no sedimento, as análises foram realizadas no Acme Analytical Laboratories Ltd. (Vancouver, Canadá). Foi efetuada análise de elementos, na forma lixiviada, pelo método de extração por Aqua Regia, referida como digestão suave (mild digestion) no documento do governo canadense CCME (1995). Este método tem o mesmo princípio que o método EPA-3050b, da agência ambiental dos Estados Unidos, Environmental Protection Agency - EPA, que é liberar os elementos fracamente ligados ao sedimento, i.e. biologiacemnte disponíveis (e.g. associados à matéria orgânca, argilas, óxidos hidratados e carbonatos), sem causar ataque aos fragmentos cristalinos (constituídos pela matriz de silicato e elementos a ela associados).

Segundo o método, para solubilização das amostras utilizou-se $6 \mathrm{~mL} / \mathrm{g}$ de água régia, i.e. $\mathrm{HNO}^{3}+\mathrm{HCl}$, que foi adicionada a $0,5 \mathrm{~g}$ de sedimento seco em tubos de teste, seguido de aquecimento em banho maria, à $\sim 90{ }^{\circ} \mathrm{C}$, por 60 minutos. Após resfriamento, as soluções foram filtradas em membrana mista de éster de celulose de 0,45 m e avolumadas para 10,0 mL com água deionizada. As concentrações dos elementos Alumínio ( $\mathrm{Al})$, Arsênio(As), Bário(Ba), Cádmio $(\mathrm{Cd})$, Cobalto (Co), Cromo (Cr), Cobre (Cu), Ferro (Fe), Mercúrio (Hg), Lítio (Li), Magnésio(Mg), Manganês (Mn), Níquel (Ni), Chumbo (Pb), Escândio (Sc), Estrôncio (Sr), Titânio (Ti), Vanádio (V) e Zinco (Zn) foram determinadas utilizando-se um Espectrômetro de Emissão Atômica Sequencial Ciros Vision da Spectro Co. Os dados adquiridos foram certificados com British Columbia Certified Assayer e foram utilizados sedimentos padrões para o controle de qualidade da American National Standards Institute, Inc.

Para efeito de comparação com os resultados obtidos no presente trabalho foi adotada os valores guia de causa-efeito da resolução CONAMA no 344/2004, onde estabelece diretrizes gerais e procedimentos mínimos adequados para a avaliação do material a ser dragado, visando o gerenciamento de sua disposição em águas jurisdicionais brasileiras ou em área emersa, avaliando seu impacto ao meio. Esta resolução define critérios de qualidade, a partir de dois níveis, nível 1 - limiar abaixo do qual se prevê baixa probabilidade de efeitos adversos à biota e nível 2 - limiar acima do qual prevê-se um provável efeito adverso à biota.

Para comparação mais ampla, também foi adotada a Lista Canadense de Qualidade Ambiental (CCME, 2002), que estabelece limites para compostos 
considerados nocivos em sedimentos para a biota marinha. Estes limites são o "Threshold Effect Level" (TEL - nível limiar de efeitos) e "Probable Effect Level" (PEL - nível provável de efeitos). Valores de um elemento ou de um composto químico abaixo do TEL indicam que raramente ocorrerá efeitos adversos à biota. Contudo, valores acima de PEL indicam que muito provavelmente a biota será afetada.

Também foi calculado o fator de enriquecimento (EF) para todos os elementos analisados. Esse fator tem sido amplamente utilizado por diversos autores na tentativa de estabelecer a contribuicão antropogênica ou biogênica versus origem crustal (e.g. Lee et al.,1994; Soto-Jiménez et al., 2001; Liu et al., 2003; Moreira et al., 2003; Luiz-Silva et al., 2006; Hortellani et al.,2008; Lu et al.,2009).

Segundo Lee et al.(1994) o fator de enriquecimento foi introduzido por Rahn (1971) como um meio de determinar se um dado elemento está enriquecido em relação ao que seria encontrado, normalmente, em uma fonte crustal.O EF compara a razão da concentração do elemento na amostra com um elemento de referência normalizador e a razão correspondente de um local de referência, teoricamente não enriquecido, chamado de "background", dado pela fórmula:

$$
E F=\frac{\text { concentração do elemento } x \text { na amostra/concentração do elemento de referência na amostra }}{\text { concentração do elemento } x \text { no background/concentração do elemento de referência no background }}
$$

Para este estudo foi escolhido o escândio (Sc) como elemento normalizador, dado que é um elemento, virtualmente, sem aplicações industriais e tendo sua origem como que quase inteiramente crustal. (Lee et al., 1994;Grousset et al., 1995; Liu et al., 2003). No caso, a maioria dos autores, utiliza o teor de elementos totais, i.e. não lixiviado, para a comparação com o background Folhelho Médio Mundial (e.g. Turekian et al., 1961). Em contrapartida, como a metodologia escolhida foi a lixiviada, para comparar os teores dos elementos com os dos foraminíferos, preferiu-se não utilizadar o Folhelo Médio Mundial como refêrencia. Dessa forma, para este estudo foi utilizado o ponto CTR para ser o local de referência, localizado distante da região sobre influência dos emissários submarinos no Canal de São Sebastião. Em um estudo de elementos-traço em ostras e em sedimento, os autores Soto-Jiménez 
et al. (2001) utilizam o EF em teores obtidos pela metodologia de extração por lixiviação, semelhante a utilizada neste trabalho, obtendo bons resultados.

Segundo a classificação de Lu et al. (2009), sob valores de EF abaixo de 2 os sedimentos estão deficientemente ou, até, minimamente enriquecidos; de 2 a 5 estão moderadamente enriquecidos; de 5 a 20 estão significantemente enriquecidos; de 20 a 40 estão muito enriquecidos; e acima de 40 estão extremamente enriquecidos.

\subsection{ELEMENTOS-TRAÇO CONTIDOS NAS CARAPAÇAS DE FORAMINÍFEROS}

No Laboratório de Micropaleontologia Setembrino Petri foram realizadas rotinas relacionadas aos tratamento dos foraminíferos. Foram utilizados $10 \mathrm{~cm}^{3}$ de sedimento de cada amostra, que foram peneirados a úmido, em peneira de 0,062 mm (Schröder et al., 1987).

As frações retidas em cada peneira foram filtradas em papel de $3 \mu \mathrm{m}$, e secas em estufa a $60^{\circ} \mathrm{C}$. Depois de seco, o material lavado foi transferido para placa de Petri e triado, sob microscópio estereoscópio Zeiss Stemi SV 6. A triagem consistiu em separar 32 carapaças de Ammonia tepida de tamanho igual ou superior a $150 \mu \mathrm{m}( \pm 23 \mu \mathrm{g})$ do restante da amostra (e.g. outras espécies, restos vegetais e componentes mineralógicos do sedimento). Dentre essas carapaças foram selecionadas 16 tingidas com corante Rosa de Bengala (i.e. indivíduos vivos) e 16 não coradas (i.e. indivíduos mortos). A identificação de Ammonia tepida foi baseada por meio de comparação de suas características morfológicas com as observadas nas pranchas constantes em Loeblich e Tappan (1988) e Cushman, (1950).

Os foraminíferos triados foram transferidos para lâminas plásticas de fundo escuro e medidos por meio do analisador de imagens AnalySIS, com intuito de selecionar somente indivíduos adultos e não deformados. 
5.3.1 Análise qualitativa de elementos-traço

As rotinas analíticas de microscopia eletrônica foram realizadas no Laboratório de Microscopia Eletrônica de Varredura do IGc-USP.

Foram colados dois indivíduos representativos dos 30 coletados de cada amostra, um corado e outro não corado, em suportes metálicos do tipo stub, e recobertos com uma fina camada de carbono. Este procedimento possibilitou a observação no Microscópio Eletrônico de Varredura (MEV) para caracterizar qualitativamente a ocorrência de elementos-traços em nanopartículas adsorvidas e outros elementos junto a carapaças dos foraminíferos. O MEV, acoplado a espectrômetro de energia dispersiva (EDS), permite acessar a composição química das carapaças, bem como detectar a presença de nanopartículas. O EDS é uma técnica empregada para coletar e determinar a energia e o número de raios-x que desprendem dos átomos em um material (Goldstein et al., 2003).

Posteriormente, para os indivíduos que se mostraram pertinentes (i.e. com particulas estranhas adsorvidas ou composição química anômala da carapaça carbonática), foram geradas imagens digitais e imagens de raios- $x$ retroespalhados para a identificação de anomalias composicionais. Nestas últimas foram realizadas a composição elemental qualitativa por EDS. As imagens digitais adquiridas foram tratadas no programa computacional Adobe Photoshop.

\subsubsection{Limpeza das carapaças}

A rotina de limpeza das carapaças baseou-se nos métodos de Martin \& Lea (2002) e Barker et al. (2003). Primeiramente, a superfície de cada carapaça, dando mais ênfase à região umbilical, foi examinada sob microscópio estereoscópio com intuito detectar a presença de partículas exógenas. Caso fosse detectado material alóctone, o mesmo era retirado com auxílio de pincel.

Posteriormente, as carapaças foram gentilmente esmagadas entre duas lamínulas para verificar a presença de possíveis grãos silicáticos no interior das câmaras (Barker et al. 2003). Se detectados, os mesmos eram retirados. Depois de esmagadas parcialmente e limpas, as carapaças foram colocadas, com auxílio de um pincel umedecido em água deionizada, em vials do tipo Ependorff, previamente descontaminados. 
Com objetivo de evitar ao máximo contaminação externa, as próximas etapas de limpeza, descritas a seguir, foram realizadas dentro de uma capela de fluxo laminar de em um laboratório ultra limpo do Centro de Pesquisas Geocronológicas do IGc-USP.

As carapaças foram lavadas com água deionizada por agitação mecânica em banheira de ultra som, para serem retirados grãos detríticos. Após esta etapa, as carapaças foram limpas com os seguintes reagentes ultrapuros: 1) etanol, 2) peróxido de hidrogênio a $30 \%$, 3) ácido dietilenotriamina penta acético (DTPA) a $0,002 M, 4)$ solução de citrato de amônio a $0.25 M$ e hidróxido de amônio a 30 \% e 5) ácido nítrico a 0,001 M (Martin \& Lea, 2002).

\subsubsection{Análise quantitativa de elementos-traço}

As carapaças, depois de limpas, foram enviadas para o Laboratório DFGResearch Center Ocean Margins da Universidade de Bremen, Alemanha. As concentrações de elementos-traço das amostras dissolvidas foram analisadas por via de Espectrômetro de Emissão Atômica ICP-OES (Perkin Elmer Optima 3300 R). Para o controle de qualidade, os dados foram certificados com padrões analíticos. Para o presente estudo, foram mensuradas as concentrações dos elementos-traço $\mathrm{Ca}, \mathrm{Sr}, \mathrm{Mn}, \mathrm{Fe}, \mathrm{Ba}, \mathrm{Zn}$ e Al.

\subsection{ANÁLISE ESTATÍSTICA}

Para a realização das análises estatísticas presentes neste estudo, foi utilizado o programa computacional estatístico Minitab ${ }$ 15, da empresa Minitab Inc.

Foram realizadas matrizes de correlação, exibindo o coeficiente de correlação de Pearson, para medir o grau do relacionamento linear entre duas variáveis. O coeficiente de correlação assume um valor entre -1 e +1 . Se uma variável tende a aumentar quando a outra diminui, o coeficiente de correlação é negativo. Reciprocamente, se as duas variáveis tendem a aumentar juntas, o coeficiente de correlação é positivo. 
Na matriz de correlação foram adotados como alfa os valores de 0,01 para correlação altamente significativa e 0,05 para correlação significativa. O valor-p determina a adequação de se rejeitar a hipótese nula em um teste de hipóteses. O valor-p varia de 0 a 1 . Quanto menor for o valor-p, menor será a probabilidade da rejeição da hipótese nula ser um erro. Se o valor-p de um teste estatístico for menor que o seu alfa, deve-se rejeitar a hipótese nula.

Foram realizados diagramas de caixa (Boxplot) para avaliar e comparar as distribuições amostrais (Figura 5.4). Nesses diagramas é possível observar a mediana, o primeiro quartil (Q1) (25\% dos dados são menores ou iguais a este valor), o terceiro quartil (Q3) (75\% dos dados são menores ou iguais a este valor), o máximo, o mínino e os valores discrepantes (outliers). São considerados discrepantes os valores que estiverem abaixo de (Q1-1,5(Q3-Q1)) ou acima de (Q3+1.5(Q3-Q1)).

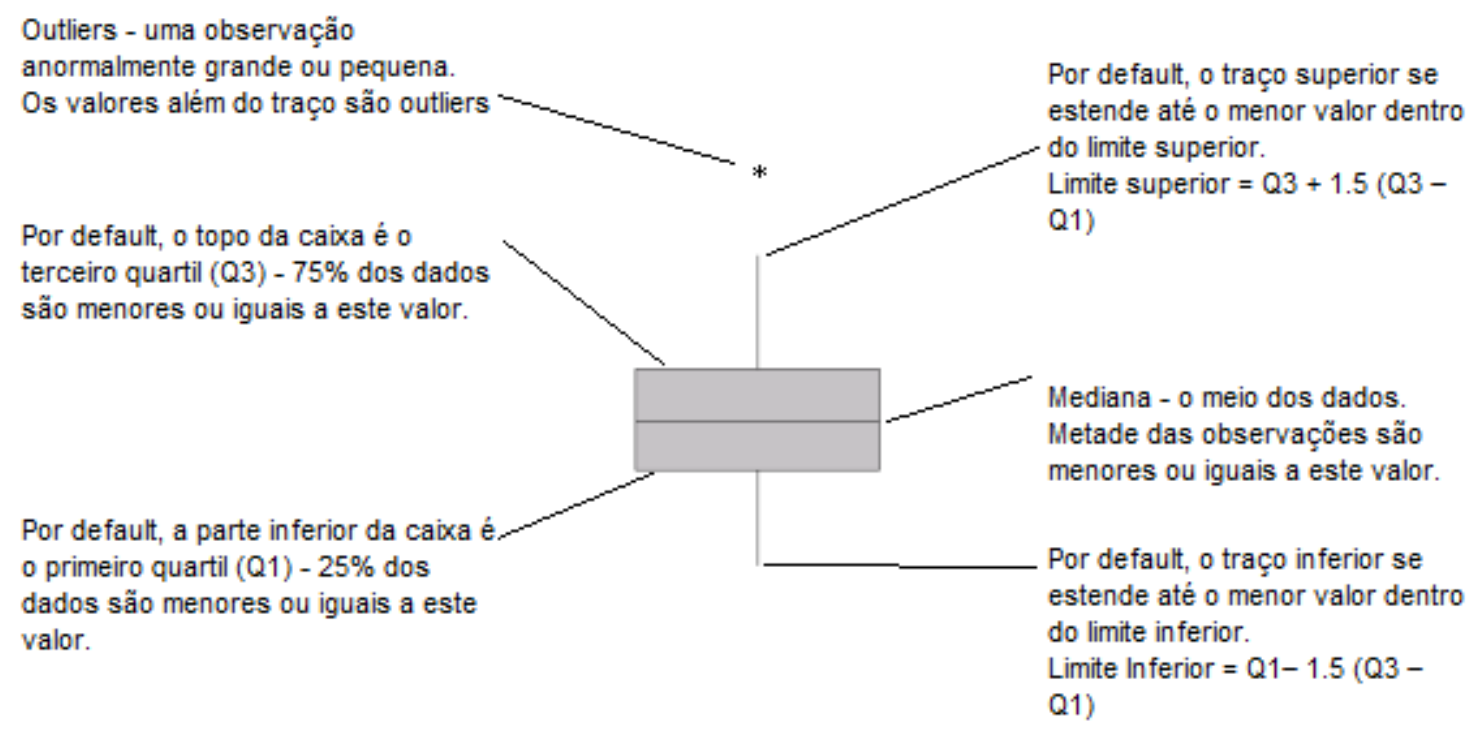

Figura 5.4 - Constituintes do diagrama de caixa (Boxplot). 


\section{RESULTADOS}

\subsection{EMISSÁRIO DO ARAÇÁ}

6.1.1 Parâmetros Físico-químicos e Microbiológicos

Na Tabela 6.1.1 (Anexo 1), encontram-se discriminadas as localizações, e os dados físico-químicos e microbiológicos obtidos para o emissário do Araçá.

A profundidade máxima dos pontos amostrais variou de 3 a $15 \mathrm{~m}$. O ponto A5 foi o mais raso e o ponto A9, o mais profundo.

A temperatura da água, nos pontos mensurados, variou de 26,4 a $30^{\circ} \mathrm{C}$. A menor temperatura foi observada no ponto $A 9$ (fundo) e a maior, no ponto $A 6$ (superfície). Observou-se tênue estratificação térmica na região amostrada.

Os valores de $\mathrm{pH}$ revelaram-se homogêneos para as águas de superfície, meio e fundo, variando de 7,98 a 8,16.

As medidas de turbidez variaram de 0,62 (superfície do ponto $A 2$ e meio do ponto A6) a 3.8 NTU (superfície do ponto A1). A região apresentou baixos índices de turbidez, com distribuição heterogênea de valores.

Os dados de fenol, óleos, graxas, nitrogênio amoniacal, nitrogênio Kjeldahl total, fósforo total, ortofosfato não ultrapassaram o limite de deteç̧ão do método analítico (descritos na Tabela 6.1.1).

Não foi detectada presença de coliformes termotolerantes e enterococos, nos pontos amostrados.

\subsubsection{Dados Sedimentológicos}

\subsubsection{Granulometria}

Os resultados da análise granulométrica dos sedimentos coletados na região do emissário submarino de esgoto do Araçá encontram-se ilustrados na Tabela 6.1.2.1.

Segundo a classificação de Shepard (1954), os sedimentos existentes na região próxima ao emissário do Araçá, são: areia, nos pontos $A 1, A 2, A 6$ e $A 7$ areia síltica, nos pontos $A 3, A 4, A 5, A 8, A 9$ e CTR silte arenoso, no ponto A10 (Figura 6.1.2.1). O grau de seleção dos sedimentos, calculado por meio do desvio padrão (Folk \& Ward, 1957; Tabela 6.1.2.1), foi definido como 
pobremente selecionado para os pontos A1, A4, A5, e CTR muito pobremente selecionado para os demais pontos.

As maiores porcentagens de areia foram observadas nos pontos $A 1, A 2$, A5 e A6, com valores de 78,55 \%, 85,74 \%, 73,12 \% e 79,46 \%, respectivamente. Os sedimentos pelíticos, em suas maiores concentrações, foram constatados nos pontos A3, A4, A8, A9 e A10, com valores de 36,67 \%, $33,22 \%, 33,68 \%, 47,90 \%$ e 71,02 \%, respectivamente. Tais pontos estão associados a locais de maior profundidade, no relevo de fundo (Figura 6.1.2.1) .

Grânulos foram observados, em sua maior abundância, nos pontos A7, A8 e A9, com valores de 19,02 \%, 25,48 \% e 14,02 \%, respectivamente (Figura 6.1.2.1). 
Tabela 6.1.2.1 - Granulometria dos sedimentos amostrados na região do emissário submarino do Araçá.

\begin{tabular}{|c|c|c|c|c|c|c|c|c|c|c|c|c|}
\hline \multirow{3}{*}{$\begin{array}{c} \\
\text { Pontos } \\
\text { de } \\
\text { Coleta }\end{array}$} & \multicolumn{2}{|c|}{$\begin{array}{l}\text { Parâmetros } \\
\text { Estatísticos }\end{array}$} & \multicolumn{10}{|c|}{ Faixa Granulométrica (\%) } \\
\hline & \multirow{2}{*}{$\begin{array}{l}\text { Diâmetro } \\
\text { Médio }\end{array}$} & \multirow{2}{*}{$\begin{array}{l}\text { Desvio } \\
\text { Padrão }\end{array}$} & \multirow{2}{*}{$\begin{array}{l}\text { Cascalho } \\
\text { Grânulos }\end{array}$} & \multicolumn{6}{|c|}{ Areia } & \multicolumn{3}{|c|}{ Pelíticos } \\
\hline & & & & Grossa & Grossa & Média & Fina & Fina & Total & Argila & Silte & Total \\
\hline $\mathrm{A} 1$ & 3,98 & 1,95 & 0,07 & 1,05 & 0,77 & 3,07 & 10,61 & 63,05 & 78,55 & 8,35 & 13,03 & 21,38 \\
\hline$A 2$ & 2,32 & 2,29 & 1,78 & 3,64 & 23,12 & 34,30 & 8,45 & 16,23 & 85,74 & 5,86 & 6,63 & 12,49 \\
\hline A3 & 4,42 & 2,33 & 0,00 & 0,14 & 0,97 & 8,51 & 13,63 & 40,07 & 63,33 & 12,78 & 23,89 & 36,67 \\
\hline A4 & 4,39 & 1,90 & 0,00 & 0,00 & 0,49 & 1,60 & 7,43 & 57,25 & 66,78 & 9,58 & 23,65 & 33,22 \\
\hline A5 & 4,08 & 1,54 & 0,51 & 0,47 & 0,71 & 1,36 & 3,17 & 67,41 & 73,12 & 4,89 & 21,48 & 26,37 \\
\hline A6 & 3,34 & 2,30 & 0,30 & 0,63 & 5,85 & 23,18 & 23,40 & 26,40 & 79,46 & 8,49 & 11,75 & 20,24 \\
\hline A7 & 1,88 & 2,50 & 19,02 & 12,31 & 9,51 & 9,87 & 10,02 & 24,93 & 66,65 & 2,35 & 11,99 & 14,33 \\
\hline A8 & 2,63 & 3,54 & 25,48 & 10,90 & 7,84 & 5,41 & 2,76 & 13,92 & 40,84 & 10,52 & 23,16 & 33,68 \\
\hline A9 & 3,72 & 3,33 & 14,02 & 7,05 & 5,66 & 5,31 & 7,40 & 12,65 & 38,08 & 11,59 & 36,31 & 47,90 \\
\hline A10 & 5,85 & 2,18 & 0,00 & 0,00 & 0,11 & 1,09 & 5,62 & 22,16 & 28,98 & 20,75 & 50,27 & 71,02 \\
\hline CTR & 4,77 & 1,94 & 0,00 & 0,05 & 0,8 & 2,61 & 6,96 & 37,68 & 48,1 & 42,66 & 9,25 & 51,9 \\
\hline
\end{tabular}



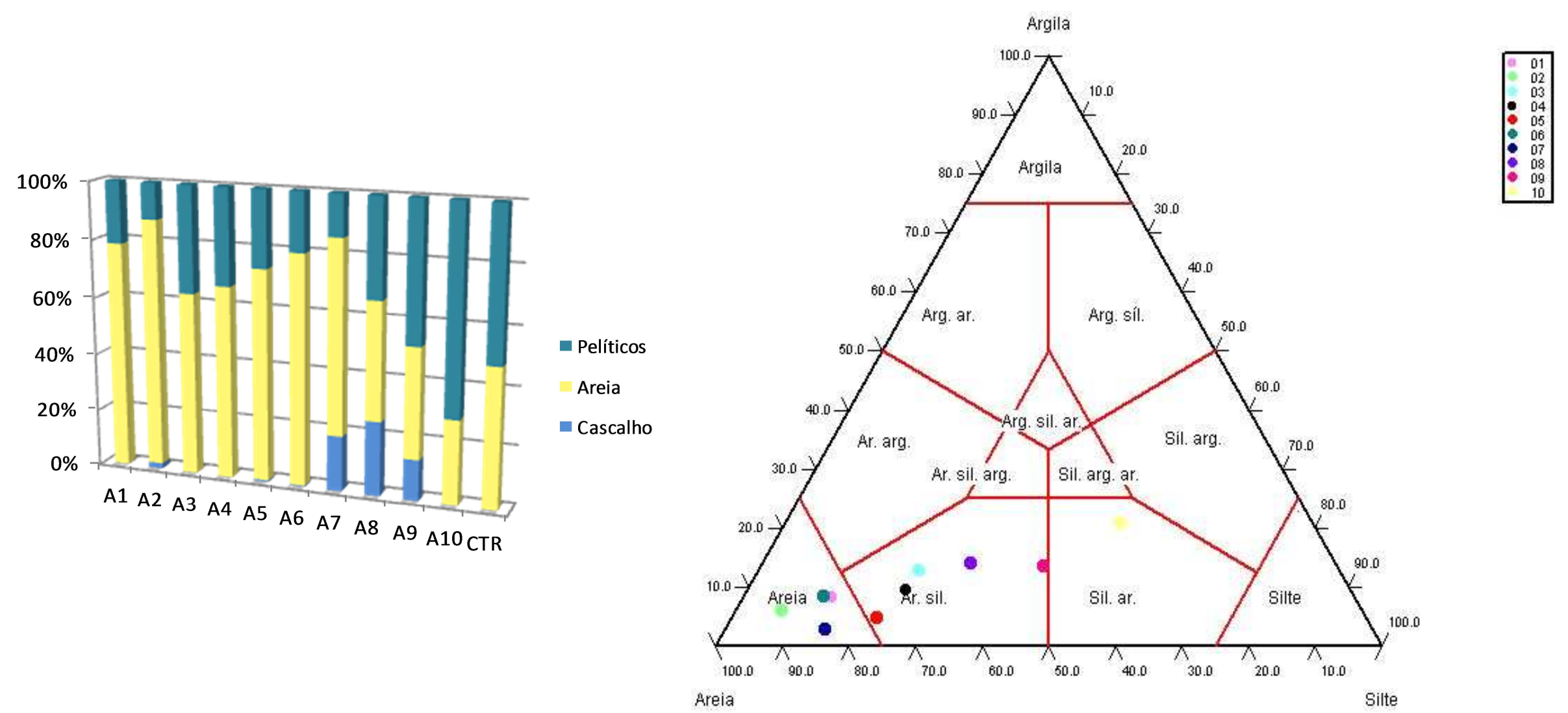

Figura 6.1.2.1 - Distribuição granulométrica e classificação dos sedimentos na região do emissário submarino do Araçá. 


\subsubsection{Geoquímica}

6.1.2.2.1 Carbonato de Cálcio, Carbono Orgânico, Nitrogênio Total, Enxofre Total, Fósforo Orgânico e Inorgânico e razões C/S e C/N

$\mathrm{Na}$ Tabela 6.1.2.2.1 podem ser verificados os dados de carbonato de cálcio, carbono orgânico, nitrogênio total, enxofre total, fósforo orgânico, fósforo inorgânico e razões C/N e C/S. Dentre os dados estão contemplados o valores mínimo, máximo, a média, o desvio padrão do conjunto de dados e valores do ponto controle (CTR). Na Figuras 6.1.2.2.1A e 6.1.2.2.1B foram ilustrados gráficos de distribuição espacial dos teores supra citados.

Os teores de carbonato de cálcio variaram entre 7,61 a 25,38 \% ( $\bar{x}=13,39$ $\%, s=6,90 \%)$, sendo os maiores valores encontrados nos pontos A8, A9 e A10 (Figura 6.1.2.2.1A). Segundo a classificação de Larsonneur et al. (1982), todos os pontos amostrais indicariam ambiente de sedimentação litoclástica.

As concentrações de carbono orgânico variaram de 0,02 a 2,66 \%( $\bar{x}=1,29$ $\%, s=0,90 \%)$. As maiores porcentagens foram obtidas nos pontos A8, A9 e A10, com valores de 2,14 \%, 2,66 \% e 2,63 \%, respectivamente. O menor valor foi encontrado no ponto $A 2$, região onde se encontra a menor concentração de sedimentos pelíticos (Figura 6.1.2.2.1A).

Os resultados obtidos de nitrogênio total variaram de 0,11 a 0,31 \% $(\bar{x}=0,19 \%, s=0,07 \%)$. Os menores valores foram evidenciados nos pontos A3, A4 e A5, com valores de 0,11 \%, 0,11 \% e 0,12 \%, respectivamente, e os maiores teores foram obtidos nos pontos A9 e A10, de 0,29 \% e 0,31 \%, respectivamente (Figura 6.1.2.2.1A).

As porcentagens de enxofre total verificadas nos sedimentos variaram de 0,084 a $0,473 \%(\bar{x}=0,28 \%, s=0,12 \%)$, nos pontos A2 e A9, respectivamente. Em relação aos demais pontos, os pontos $A 9$ e $A 10$ apresentaram as maiores concentrações de enxofre, i.e. 0,473 e 0,445 \%, respectivamente (Figura 6.1.2.2.1A).

As concentrações de fósforo total variaram de 0,040 a 0,087\% ( $\bar{x}=0,057$ $\%, s=0,015 \%)$. A maior porcentagem foi observada no ponto $A 6$ e as menores, nos pontos $1 \mathrm{~A}$ e $5 \mathrm{~A}$ (Figura 6.1.2.2.1B). Os teores de fósforo orgânico variaram de 0,002 a $0,020 \%(\bar{x}=0,013 \%, s=0,007 \%)$, com maiores concentrações presentes nos pontos A3, A4, A5 e A10, apresentando valores de 0,020 \%, 0,020 $\%, 0,019 \%$ e 0,017 \%, respectivamente (Figura 6.1.2.2.1B). Valores de fósforo 
inorgânico oscilaram entre 0,024 a $0,078 \%(\bar{x}=0,043 \%, s=0,017 \%)$, sendo os maiores teores encontrados nos pontos $A 6$ e $A 9$, com valores de $0,078 \%$ e $0,059 \%$, respectivamente (Figura 6.1.2.2.1B).

Os valores encontrados para as razões $\mathrm{C} / \mathrm{S}$ indicaram a presença de ambiente anóxico no ponto $A 2$ e de sedimentos depositados sob eventos periódicos de anoxia e coluna d'água óxica nos pontos $A 1, A 3$ e $A 4$. Nos demais pontos amostrais, os valores de $\mathrm{C} / \mathrm{S}$ indicaram a presença de sedimentos $\mathrm{e}$ coluna d'água óxica (Figura 6.1.2.2.1B).

Os resultados das razões $\mathrm{C} / \mathrm{N}$ indicaram que a matéria orgânica dos pontos A3, A4, A5, A8, A9 e A10 é de origem mista; nos pontos A1, A2, A6 e A7, de origem marinha (Figura 6.1.2.2.1B). 
Tabela 6.1.2.2.1 - Dados de carbonato de cálcio, carbono orgânico, nitrogênio, enxofre, fósforo orgânico, fósforo inorgânico e razões $\mathrm{C} / \mathrm{S}$ e $\mathrm{C} / \mathrm{N}$ da região do emissário do Araçá.

\begin{tabular}{cccccccccc}
\hline $\begin{array}{c}\text { Pontos de } \\
\text { Coleta }\end{array}$ & $\begin{array}{c}\mathrm{CaCO}_{3} \\
(\%)\end{array}$ & $\begin{array}{c}\mathrm{C} \text { org } \\
(\%)\end{array}$ & $\begin{array}{c}\mathrm{N} \\
(\%)\end{array}$ & $\begin{array}{c}\mathrm{S} \\
(\%)\end{array}$ & $\begin{array}{c}\mathrm{P} \\
(\%)\end{array}$ & $\begin{array}{c}\mathrm{P} \text { org } \\
(\%)\end{array}$ & $\begin{array}{c}\mathrm{P} \text { inorg } \\
(\%)\end{array}$ & $\mathrm{C} / \mathrm{S}$ & $\mathrm{C} / \mathrm{N}$ \\
\hline A1 & 9,69 & 0,56 & 0,14 & 0,18 & 0,040 & 0,014 & 0,025 & 3,1 & 4,0 \\
A2 & 7,61 & 0,02 & 0,15 & 0,08 & 0,047 & 0,013 & 0,035 & 0,2 & 0,1 \\
A3 & 7,75 & 0,86 & 0,11 & 0,33 & 0,062 & 0,020 & 0,042 & 2,6 & 7,8 \\
A4 & 11,01 & 0,69 & 0,11 & 0,28 & 0,046 & 0,020 & 0,026 & 2,5 & 6,3 \\
A5 & 9,54 & 1,14 & 0,12 & 0,23 & 0,043 & 0,019 & 0,024 & 5,0 & 9,5 \\
A6 & 7,71 & 0,98 & 0,23 & 0,24 & 0,087 & 0,010 & 0,078 & 4,1 & 4,3 \\
A7 & 11,33 & 1,2 & 0,21 & 0,22 & 0,046 & 0,002 & 0,044 & 5,5 & 5,7 \\
A8 & 22,97 & 2,14 & 0,18 & 0,30 & 0,065 & 0,015 & 0,050 & 7,1 & 11,9 \\
A9 & 25,38 & 2,66 & 0,29 & 0,47 & 0,063 & 0,003 & 0,059 & 5,6 & 9,2 \\
A10 & 20,93 & 2,63 & 0,31 & 0,45 & 0,066 & 0,017 & 0,049 & 5,9 & 8,5 \\
Mín. & 7,61 & 0,02 & 0,11 & 0,08 & 0,040 & 0,002 & 0,024 & - & - \\
Máx. & 25,38 & 2,66 & 0,31 & 0,47 & 0,087 & 0,002 & 0,078 & - & - \\
$\bar{x}$ & 13,39 & 1,29 & 0,19 & 0,28 & 0,057 & 0,013 & 0,043 & - & - \\
S & 6,90 & 0,90 & 0,07 & 0,12 & 0,015 & 0,007 & 0,017 & - & - \\
CTR & 14,82 & 1,80 & 0,29 & 0,36 & 0,018 & 0,005 & 0,013 & 5 & 6,2 \\
\hline
\end{tabular}




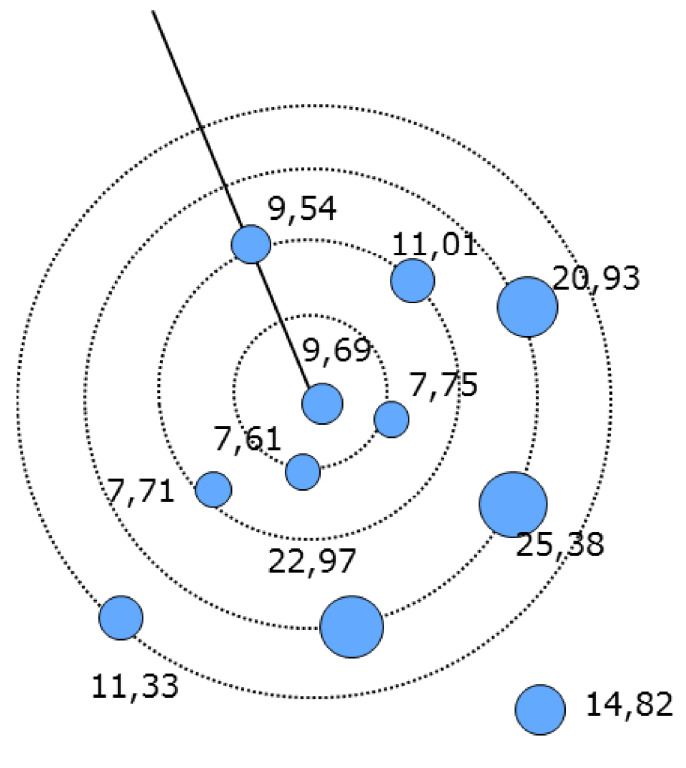

$\mathrm{CaCO}_{3}$

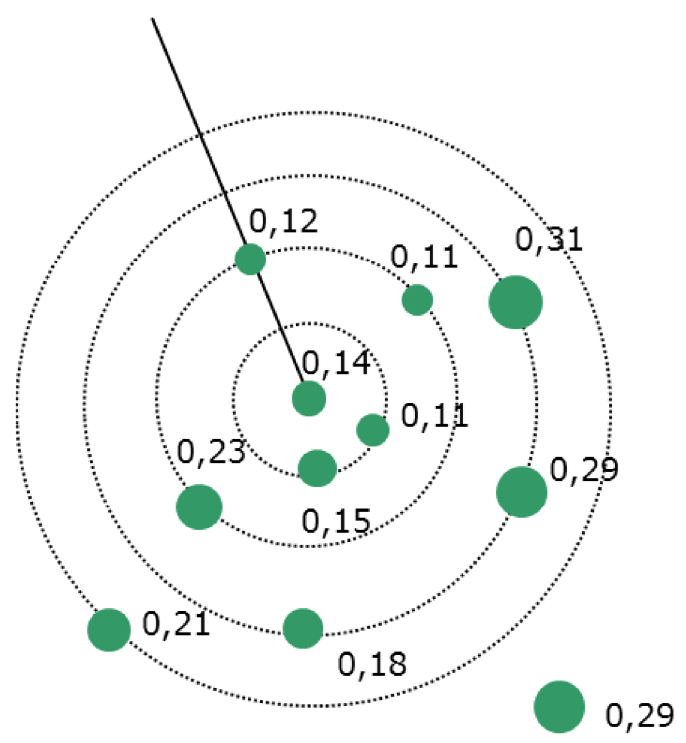

$\mathbf{N}$

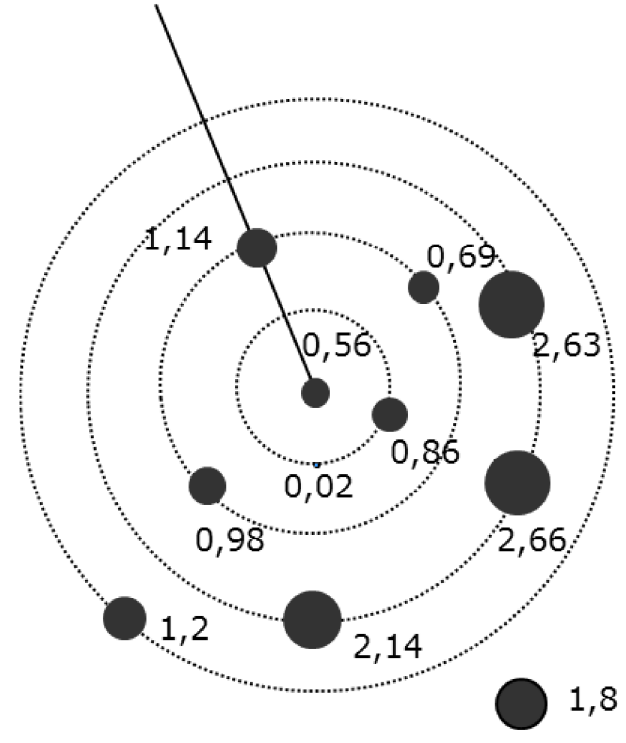

C org

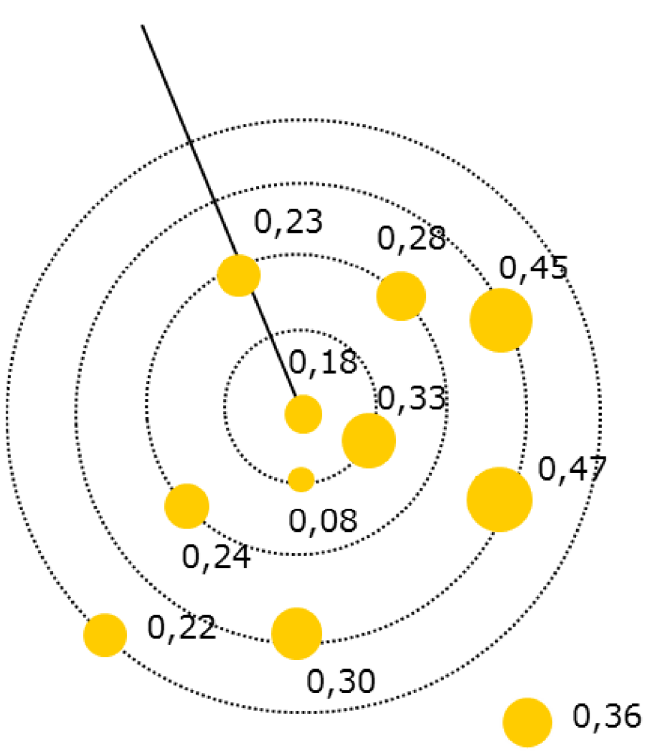

$\mathbf{S}$

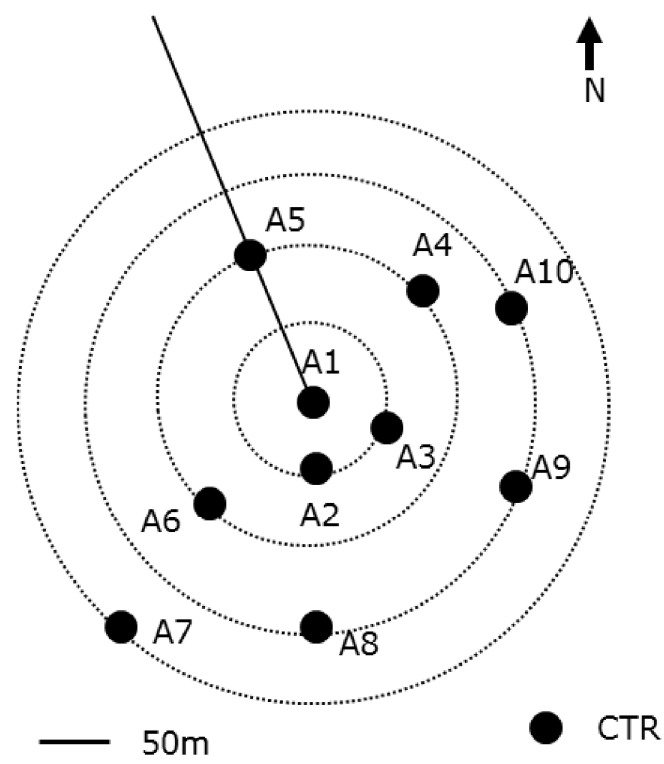

Figura 6.1.2.2.1A - Concentrações em \% de carbonato de cálcio, carbono orgânico, nitrogênio, enxofre e localização das amostras da região do emissário do Araçá. 


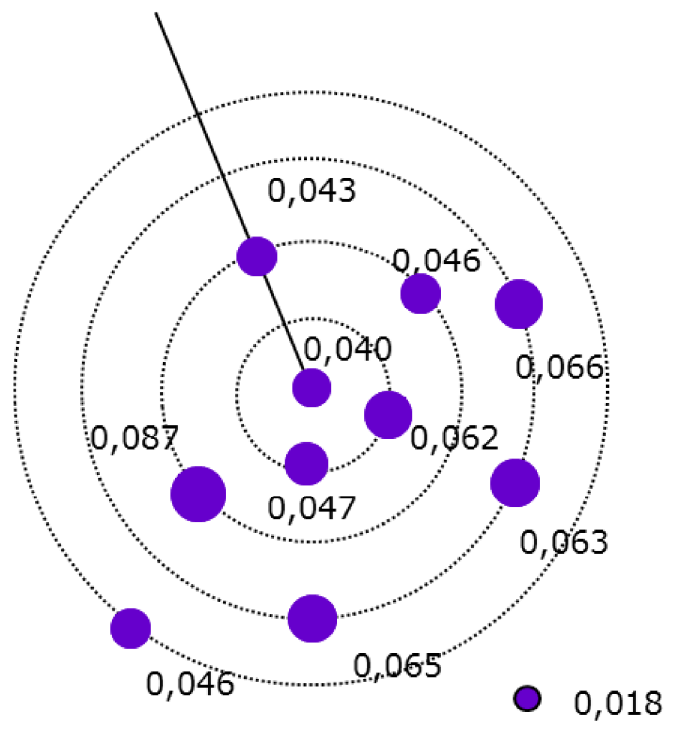

P total

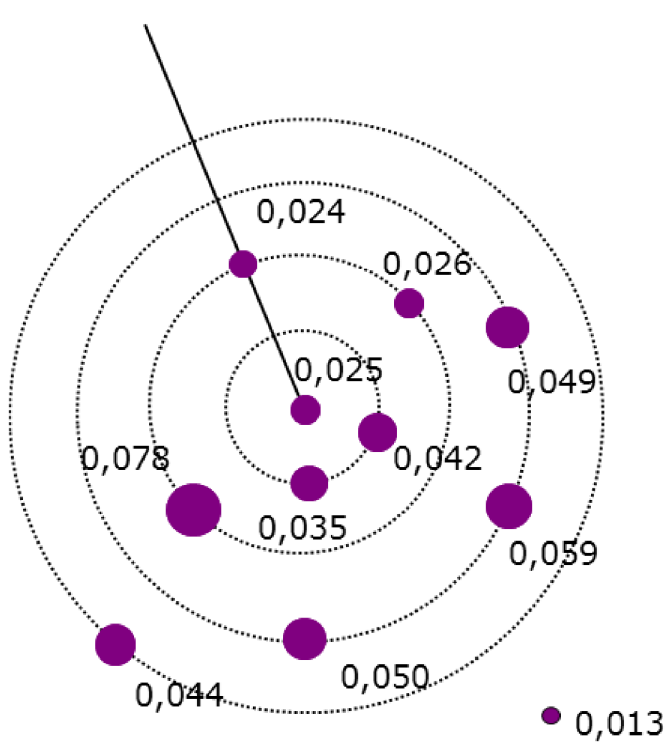

$P$ inorg
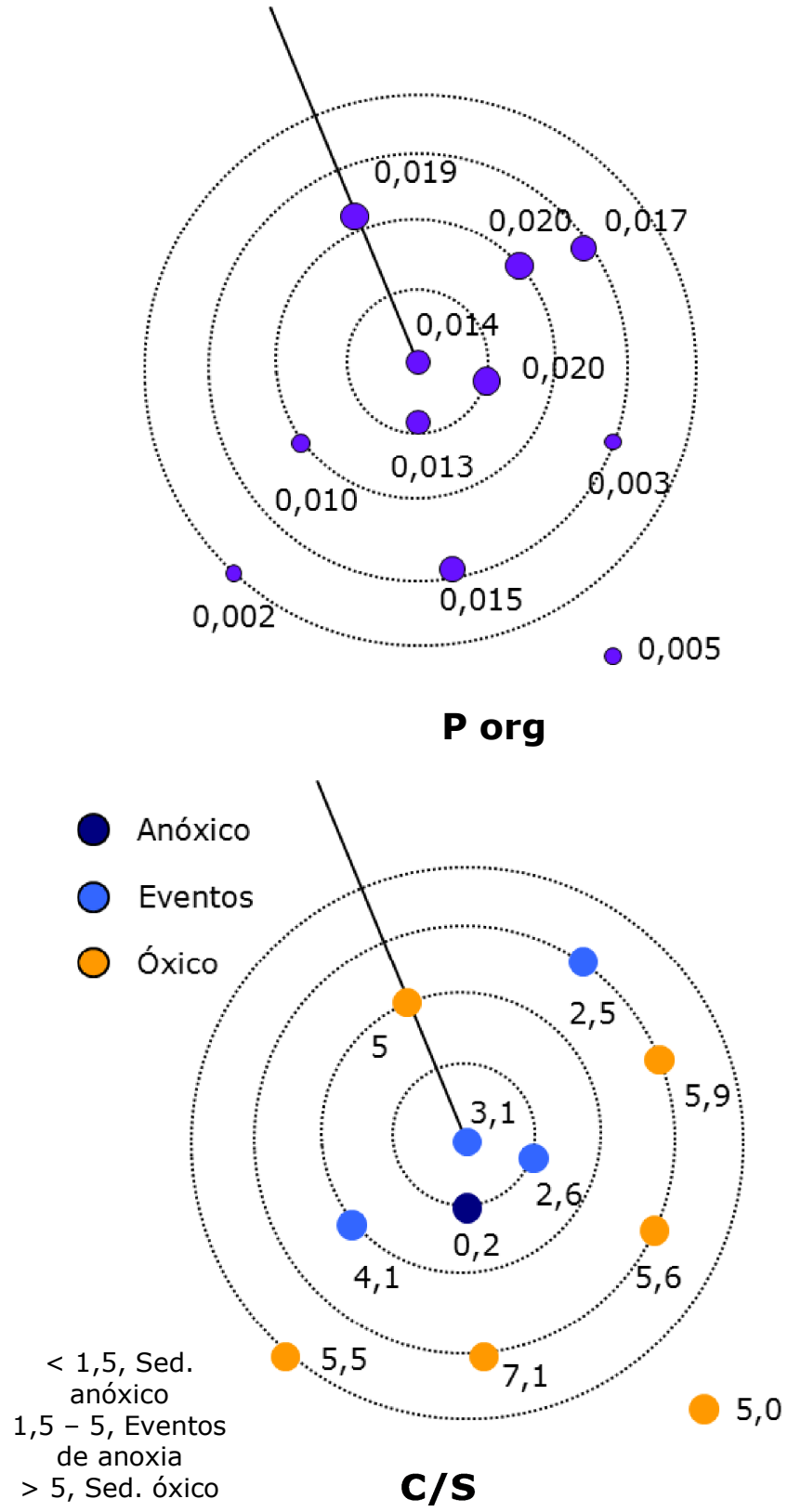
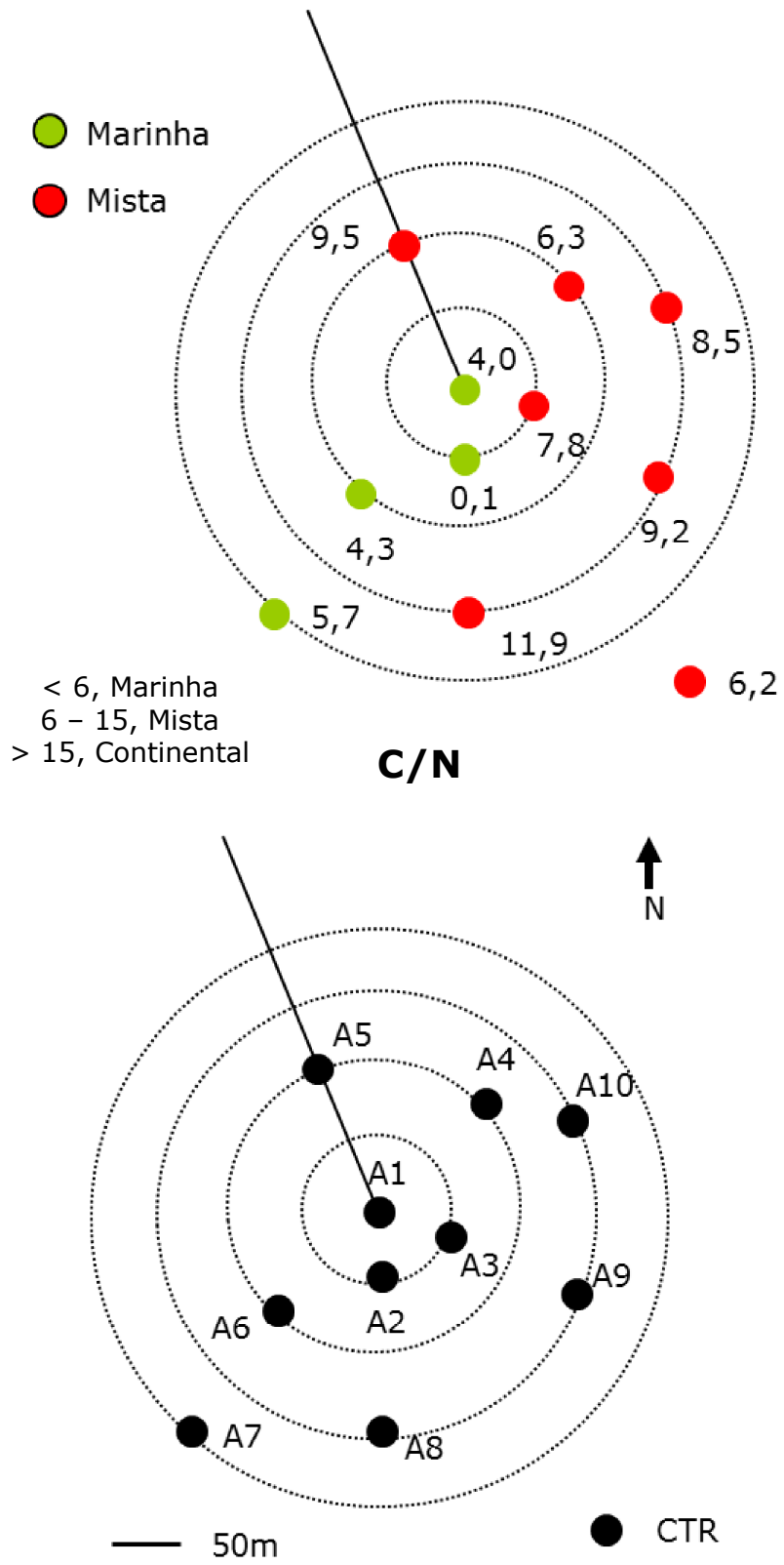

Figura 6.1.2.2.1B - Concentrações em \% de fósforo total, fósforo orgânico, fósforo inorgânico, Razão C/S e C/N e localização das amostras da região do emissário do Araçá. 


\subsection{Elementos maiores e traço contidos no sedimento}

Na tabela 6.1.2.2.2A (Anexo 2), em anexo, encontram-se os dados dos teores de Alumínio (Al), Arsênio (As), Bário (Ba), Cádmio (Cd), Cobalto (Co), Cromo ( $\mathrm{Cr})$, Cobre ( $\mathrm{Cu})$, Ferro (Fe), Mercúrio $(\mathrm{Hg})$, Lítio ( $\mathrm{Li})$, Magnésio $(\mathrm{Mg})$, Manganês (Mn), Níquel (Ni), Chumbo (Pb), Escândio (Sc), Estrôncio (Sr), Titânio (Ti), Vanádio (V) e Zinco ( $Z n$ ). Dentre os dados estão contemplados o limite TEL - nível limiar de efeitos "Threshold Effect Level", o limite PEL - nível provável de efeitos ("Probable Effect Level") (CCME, 2002), nível 1 - limiar abaixo do qual se prevê baixa probabilidade de efeitos adversos à biota, nível 2 - limiar acima do qual se prevê um provável efeito adverso à biota (CONAMA no 344/2004), os valores máximo, mínimo, a média, o desvio padrão do conjunto de dados e os valores do ponto controle (CTR). Na Figura 6.1.2.2.2, é possível observar, sumariamente, os dados supra mencionados.

$\mathrm{Na}$ Figura 6.1.2.2.2, é possível verificar que os teores dos elementos Al, As, Co, Fe, Li, Mg, Mn, Ni, Pb, Sc e V apresentaram distribuições semelhantes, com os maiores valores nos pontos $A 8, A 9$ e $A 10$ e o menor no $A 2$.

Para os elementos $\mathrm{Cu}$ e $\mathrm{Hg}$, ocorre um pico de concentração no ponto A6. Já o $\mathrm{Cr}$ teve seus maiores teores revelados no ponto $\mathrm{A} 2$.

O elemento $\mathrm{Cd}$ apresentou valores abaixo do limite de detecção, i.e. <0,01 ppm, para os pontos $A 1, A 2, A 5$ e $A 7$.

O $\mathrm{Sr}$ demonstrou as mais elevadas concentrações nos pontos A8 e A9, enquanto o Ti apresentou distribuição mais uniforme de valores.

Somente o As, no ponto A9, ficou, ligeiramente, acima do valor de referência TEL. Todos os demais elementos, com valores de referência estabelecidos, ficaram abaixo dos referidos valores.

$\mathrm{Na}$ Tabela 6.1.2.2.2B podem ser evidenciados os valores do fator de enriquecimento (EF) para cada elemento analisado. Foi utilizado o valor do ponto CTR como background e do Sc como elemento normalizador para o cálculo.

Com base no ponto controle CTR, os elementos que se demonstraram enriquecimeto moderado, em alguns pontos, foram $\mathrm{Cd}, \mathrm{Cr}, \mathrm{Cu}, \mathrm{Hg}, \mathrm{Sr}$ e $\mathrm{Ti}$. O ponto A6 apresentou enriquecimento significativo para o $\mathrm{Cd}$. 

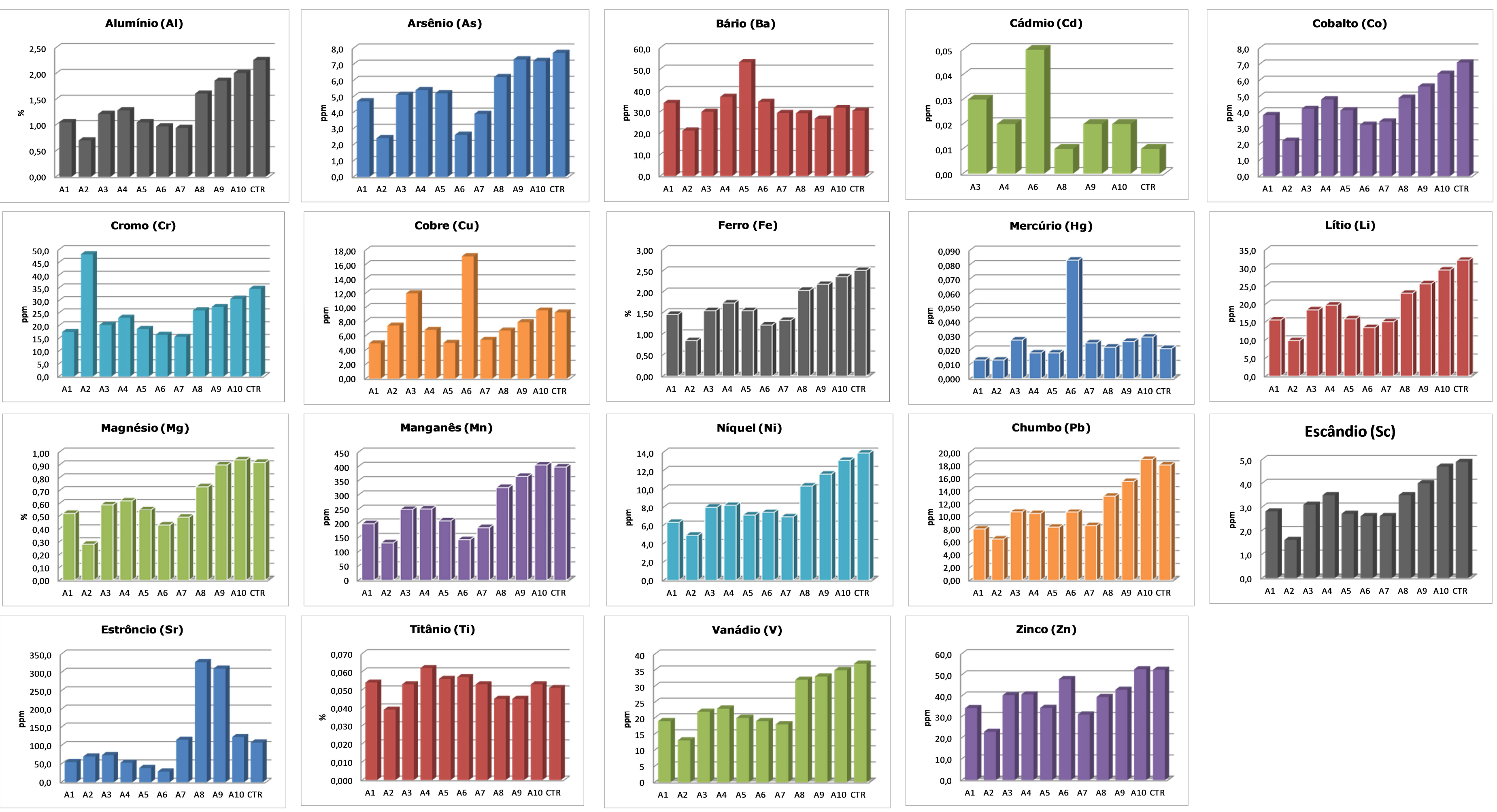

Figura 6.1.2.2.2 - Concentrações de elementos maiores e traço contidos no sedimento da região do emissário do Araçá. 
Tabela 6.1.2.2.2B - Valores do fator de enriquecimento (EF) para os elementos maiores e traço no sedimento da região do emissário do Araçá

\begin{tabular}{|c|c|c|c|c|c|c|c|c|c|c|c|c|c|c|c|c|c|c|c|}
\hline $\begin{array}{l}\frac{\pi}{0} \\
\frac{0}{0} \\
0 \\
0 \\
0 \\
0 \\
0 \\
0 \\
0 \\
0\end{array}$ & 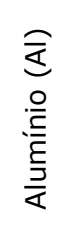 & 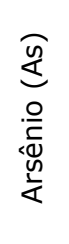 & 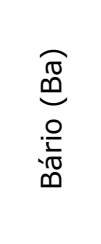 & 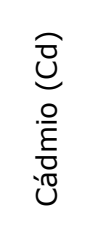 & $\begin{array}{l}\widehat{0} \\
0 \\
\frac{0}{\pi} \\
0 \\
0 \\
0\end{array}$ & 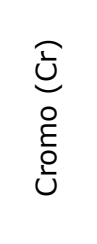 & $\begin{array}{l}\widehat{3} \\
0 \\
0 \\
0 \\
0\end{array}$ & 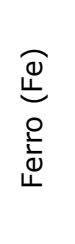 & 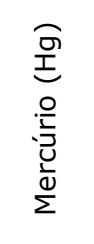 & 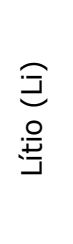 & 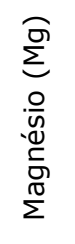 & 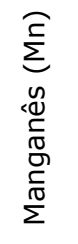 & $\begin{array}{l}\widehat{\widehat{z}} \\
\bar{\Phi} \\
\overline{\frac{\sigma}{z}}\end{array}$ & 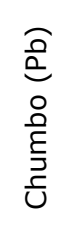 & 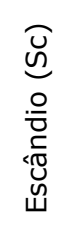 & 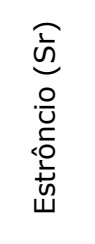 & 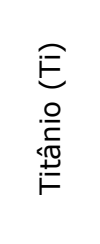 & $\begin{array}{l}\mathcal{Z} \\
.0 \\
.0 \\
-\frac{10}{10} \\
\frac{1}{10} \\
>\end{array}$ & 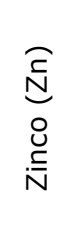 \\
\hline $\mathrm{A} 1$ & 0,8 & 1,1 & 2,0 & - & 0,9 & 0,9 & 0,9 & 1,0 & 1,1 & 1,5 & 1,0 & 0,9 & 0,8 & 0,8 & 1,0 & 0,9 & 1,9 & 0,9 & 1,1 \\
\hline$A 2$ & 0,9 & 1,0 & $2,1+$ & - & 0,9 & $4,3+$ & $2,5+$ & 1,0 & 1,9 & 0,9 & 0,9 & 1,0 & 1,1 & 1,1 & 1,0 & 2,0 & $2,3+$ & 1,1 & 1,3 \\
\hline A3 & 0,8 & 1,0 & 1,6 & $4,7+$ & 0,9 & 0,9 & $2,0 \dagger$ & 1,0 & 2,0 & 0,9 & 1,0 & 1,0 & 0,9 & 0,9 & 1,0 & 1,1 & 1,6 & 0,9 & 1,2 \\
\hline A4 & 0,8 & 1,0 & 1,7 & $2,8+$ & 0,9 & 0,9 & 1,0 & 1,0 & 1,2 & 0,9 & 0,9 & 0,9 & 0,8 & 0,8 & 1,0 & 0,7 & 1,7 & 0,9 & 1,1 \\
\hline A5 & 0,8 & 1,2 & $3,2+$ & - & 1,0 & 1,0 & 1,0 & 1,1 & 1,6 & 0,9 & 1,1 & 0,9 & 0,9 & 0,8 & 1,0 & 0,7 & 2,0 & 1,0 & 1,2 \\
\hline A6 & 0,8 & 0,6 & $2,2+$ & 9,4 ₹ & 0,8 & 0,9 & $3,5+$ & 0,9 & $7,4 \dagger$ & 0,8 & 0,9 & 0,7 & 1,0 & 1,1 & 1,0 & 0,5 & $2,1 \dagger$ & 1,0 & 1,7 \\
\hline A7 & 0,8 & 1,0 & 1,8 & - & 0,9 & 0,8 & 1,1 & 1,0 & $2,2+$ & 0,9 & 1,0 & 0,9 & 0,9 & 0,9 & 1,0 & 2,0 & 2,0 & 0,9 & 1,1 \\
\hline A8 & 1,0 & 1,1 & 1,3 & 1,4 & 1,0 & 1,1 & 1,0 & 1,1 & 1,5 & 1,0 & 1,1 & 1,1 & 1,0 & 1,0 & 1,0 & $4,2+$ & 1,2 & 1,2 & 1,1 \\
\hline A9 & 1,0 & 1,2 & 1,1 & $2,5+$ & 1,0 & 1,0 & 1,0 & 1,1 & 1,5 & 1,0 & 1,2 & 1,1 & 1,0 & 1,0 & 1,0 & $3,5+$ & 1,1 & 1,1 & 1,0 \\
\hline A10 & 0,9 & 1,0 & 1,1 & $2,1 \dagger$ & 0,9 & 0,9 & 1,1 & 1,0 & 1,4 & 1,0 & 1,1 & 1,1 & 1,0 & 1,1 & 1,0 & 1,2 & 1,1 & 1,0 & 1,0 \\
\hline
\end{tabular}

Obs.: Foi utilizado o valor do ponto CTR como background e do Sc como elemento normalizador para o cálculo.

tEnriquecimento moderado. ₹Enriqueimento significativo. 


\subsection{Análise estatística}

Na Matriz 6.1.2.2.3, encontram-se os coeficientes de Pearson para os dados de lama (silte + argila), areia, carbonato, carbono orgânico, enxofre, nitrogênio, fósforo, metais e elementos-traços contidos no sedimento da área do emissário do Araçá.

A Matriz 6.1.2.2.3 evidenciou que os elementos $\mathrm{Al}, \mathrm{As}, \mathrm{Co}, \mathrm{Fe}, \mathrm{Li}, \mathrm{Mg}, \mathrm{Mn}$, $\mathrm{Ni}, \mathrm{Pb}, \mathrm{Sc}, \mathrm{V}$ e Zn juntamente com porcentagem de finos, carbono orgânico (C org), enxofre $(\mathrm{S})$ e carbonato $\left(\mathrm{CaCO}_{3}\right)$ são correlatos e apresentam padrão de distribuição semelhante.

$\mathrm{Cu}$ e $\mathrm{Hg}$ foram correlatos ao $\mathrm{P}$ inorg, que por sua vez foram correlatos ao Cd. Já O Ba apresentou correlação significativa com o Ti. 


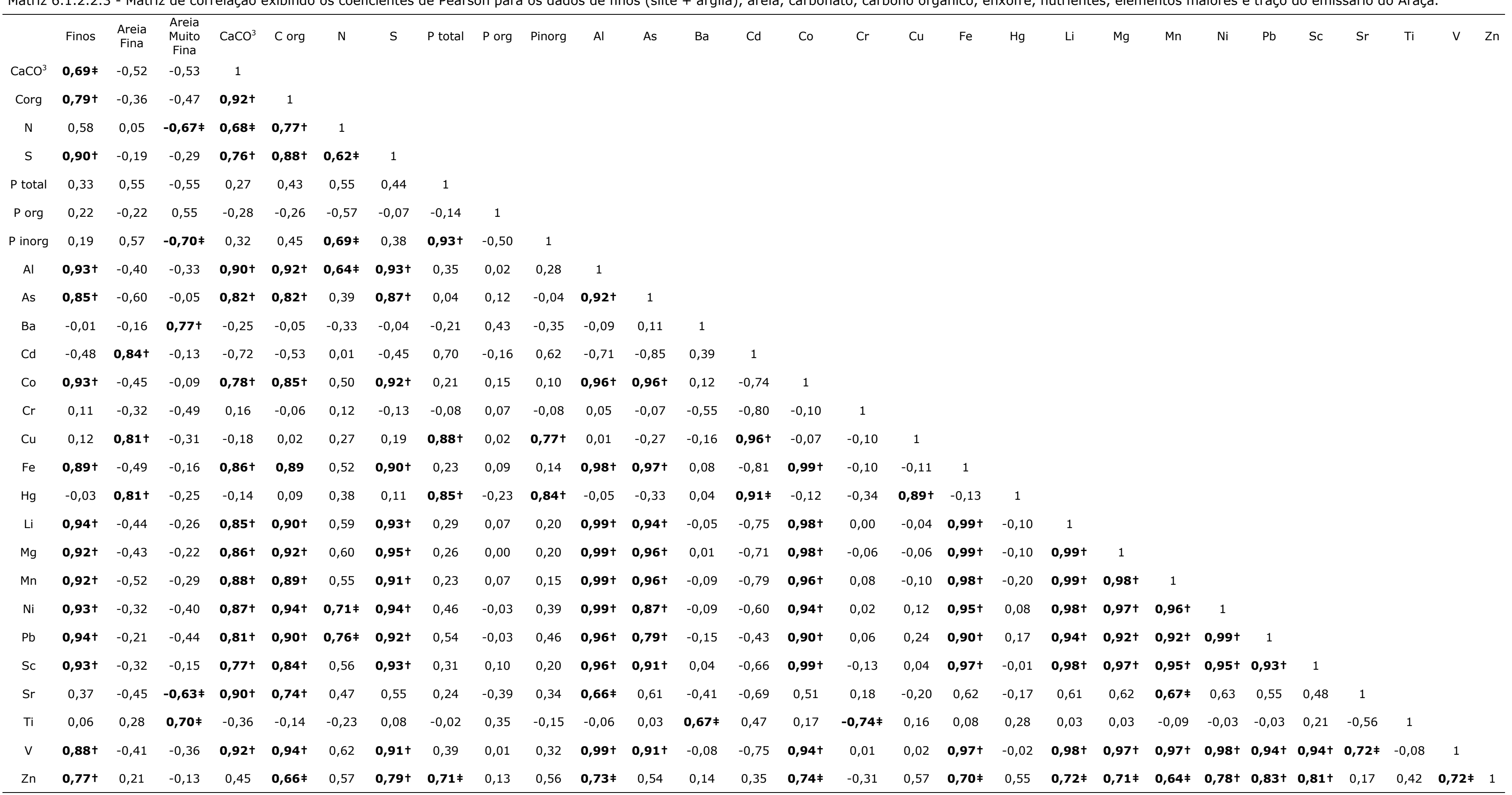

Obs. +Correlação altamente significativa para valores de $p<0,01$. $\neq$ Correlação significativa para valores $p<0,05$. (FC) - Elemento-traço carapaça corada. (F) - Elemento-traço carapaça não corada 


\subsection{EMISSÁRIO TEBAR}

\subsubsection{Parâmetros Físico-químicos e Microbiológicos}

Na Tabela 6.2.1 (Anexo 3), encontram-se mencionadas as localizações, os dados físico-químicos e microbiológicos obtidos para o emissário do Tebar.

As profundidades dos pontos amostrais variaram de 8 a $30 \mathrm{~m}$, com distribuição heterogênea. Neste sentido, o ponto T6, constituiu o mais raso e o ponto T8, o mais profundo.

A temperatura da água, nos pontos analisados, variou de 19,74 a 27,99 ${ }^{\circ} \mathrm{C}$. A menor temperatura foi observada no ponto T8 (fundo) e a maior, no ponto T7 (superfície). Verificou-se, em todos os pontos, aumento gradativo da temperatura em direção à superfície. A salinidade, por sua vez, oscilou entre 35,32 a 36,05 , com decréscimo dos valores do fundo para a superfície, em todos os pontos.

As concentrações de oxigênio dissolvido variaram de 4,7 a 6,59 $\mathrm{mg} \mathrm{L}^{-1}$, nos pontos ponto T5 (fundo) e ponto T1 (superfície), respectivamente. Em todos os pontos amostrais, foi evidenciado decréscimo progressivo na concentração da superfície para o fundo. Nos pontos T1, T3, T4, T9, T10 (fundo) e T8 (meio e fundo), os valores encontrados estiveram abaixo do limite estabelecido pelo CONAMA 357/05, i.e. $6 \mathrm{mg} \mathrm{L}^{-1}$.

Com relação aos valores de $\mathrm{pH}$, foi constatada significativa variação entre os pontos amostrados, de 5,79 a 8,11. Além disso, na superfície do ponto 8 e no ponto T9 os valores encontrados, i.e. 6,25 para o ponto T8 e 5,79, 5,88 e 5,89 para o ponto T9, ficaram abaixo do intervalo estabelecido pelo CONAMA 357/05, i.e. 6,5 a 8,5, com valores de $\mathrm{pH}$ considerados ácidos.

Os valores de turbidez obtidos oscilaram de 0,35 a 2,7, nos pontos T9 (meio) e T2 (fundo), respectivamente. A região apresentou baixos valores de turbidez, com distribuição heterogênea de valores.

Os dados de fenol, óleos, graxas, nitrogênio amoniacal, nitrogênio Kjeldahl total, fósforo total, ortofosfato não ultrapassaram o limite de deteç̧ão do método analítico.

Em grande parte dos pontos amostrados, a concentração de coliformes termotolerante e enterococos esteve abaixo do limite de detecção $(<1)$. O coliformes termotolerantes e enterococos, na maioria dos pontos, foram ausentes. Os maiores valores encontrados para coliformes termotolerantes e enterococos foram de $22 \mathrm{UFC} / 100 \mathrm{~mL}$ (ponto T7, água do meio) e $12 \mathrm{UFC} / 100 \mathrm{~mL}$ (ponto T9, água de superfície), respectivamente. 


\subsubsection{Dados Sedimentológicos}

\subsubsection{Granulometria}

Na tabela 6.2.2.1 estão apresentados os resultados da análise granulométrica, realizada nos sedimentos da região próxima aos difusores do emissário submarino TEBAR.

De acordo com a classificação proposta por Shepard (1954), os sedimentos existentes próximo ao emissário do TEBAR, são: silte arenoso nos pontos T1, T3 e T7, silte no ponto T5 e silte argiloso nos pontos T2, T4, T6, T8, T9 e T10 (Figura 6.2.2.1). O grau de seleção dos sedimentos, obtidos por meio do desvio padrão (Folk \& Ward, 1957; Tabela 6.2.2.1), foram definidos como pobremente selecionado, para os pontos T1, T2, T5, T6, T7 e T9, e muito pobremente selecionado, para os demais pontos.

À exceção do ponto T3, observou-se predominância de sedimentos pelíticos, cujas porcentagens foram superiores a $78 \%$. No ponto T3 ocorreu expressiva concentração de areia, i.e. 32,08 \%, assim como presença de grânulos, i.e. 3,21 \% (Figura 6.2.2.1). 
Tabela 6.2.2.1 - Granulometria dos sedimentos amostrados na região do emissário submarino do TEBAR.

\begin{tabular}{|c|c|c|c|c|c|c|c|c|c|c|c|c|}
\hline \multicolumn{13}{|c|}{$\begin{array}{l}\text { Parâmetros } \\
\text { Estatísticos }\end{array}$} \\
\hline \multirow{2}{*}{$\begin{array}{c}\text { Pontos } \\
\text { de Coleta }\end{array}$} & \multirow{2}{*}{$\begin{array}{l}\text { Diâmetro } \\
\text { Médio }\end{array}$} & \multirow{2}{*}{$\begin{array}{l}\text { Desvio } \\
\text { Padrão }\end{array}$} & \multirow{2}{*}{$\begin{array}{l}\text { Cascalho } \\
\text { Grânulos }\end{array}$} & \multicolumn{6}{|c|}{ Areia } & \multicolumn{3}{|c|}{ Pelíticos } \\
\hline & & & & Grossa & Grossa & Média & Fina & Fina & Total & Argila & Silte & Total \\
\hline $\mathrm{T} 1$ & 6,07 & 1,86 & 0,00 & 0,00 & 0,28 & 1,29 & 3,16 & 12,01 & 16,74 & 16,35 & 66,90 & 83,26 \\
\hline $\mathrm{T} 2$ & 6,80 & 1,92 & 0,00 & 0,00 & 0,03 & 0,08 & 0,66 & 9,07 & 9,86 & 33,92 & 56,22 & 90,14 \\
\hline T3 & 4,91 & 2,87 & 3,21 & 5,03 & 5,47 & 4,07 & 2,16 & 15,34 & 32,08 & 16,07 & 48,64 & 64,71 \\
\hline $\mathrm{T} 4$ & 5,98 & 2,19 & 0,51 & 0,58 & 1,13 & 0,66 & 1,15 & 17,26 & 20,78 & 22,97 & 55,75 & 78,71 \\
\hline T5 & 6,18 & 1,58 & 0,00 & 0,01 & 0,12 & 0,37 & 0,88 & 10,32 & 11,70 & 9,61 & 78,69 & 88,30 \\
\hline T6 & 6,49 & 1,65 & 0,07 & 0,00 & 0,00 & 0,07 & 0,36 & 7,21 & 7,63 & 21,19 & 71,11 & 92,30 \\
\hline T7 & 6,26 & 1,70 & 0,00 & 0,00 & 0,09 & 0,12 & 0,62 & 14,04 & 14,87 & 11,83 & 73,31 & 85,13 \\
\hline T8 & 6,46 & 2,14 & 0,03 & 0,13 & 0,44 & 0,67 & 1,90 & 12,67 & 15,82 & 31,38 & 52,77 & 84,15 \\
\hline T9 & 6,30 & 1,72 & 0,00 & 0,00 & 0,02 & 0,20 & 2,04 & 8,03 & 10,29 & 18,13 & 71,58 & 89,71 \\
\hline $\mathrm{T} 10$ & 6,34 & 2,15 & 0,00 & 0,02 & 0,31 & 0,69 & 1,77 & 18,33 & 21,12 & 29,72 & 49,16 & 78,88 \\
\hline CTR & 4,77 & 1,94 & 0,00 & 0,05 & 0,8 & 2,61 & 6,96 & 37,68 & 48,1 & 42,66 & 9,25 & 51,9 \\
\hline
\end{tabular}



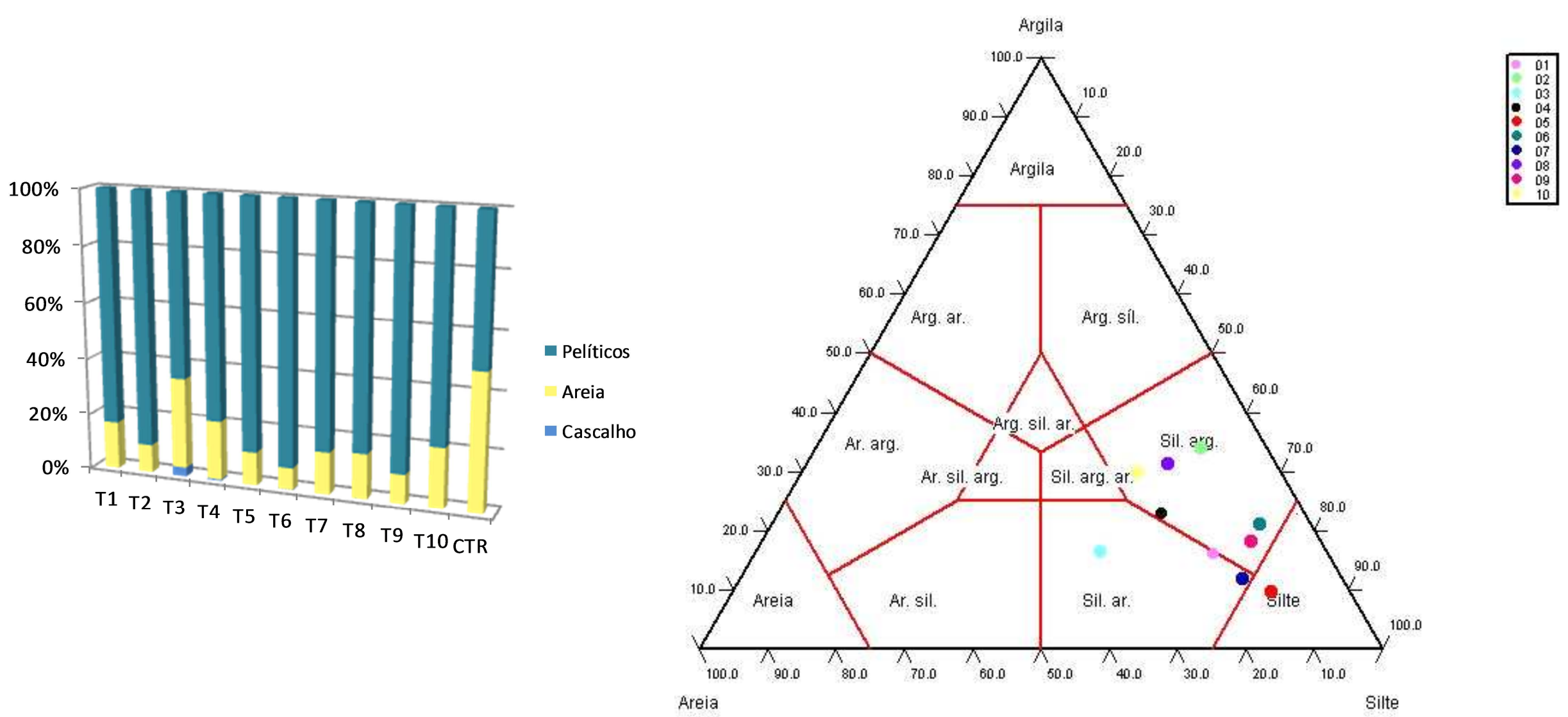

Figura 6.2.2.1 - Distribuição granulométrica e classificação dos sedimentos da região do emissário submarino do TEBAR. 


\subsubsection{Geoquímica}

6.2.2.2.1 Carbonato de Cálcio, Carbono Orgânico, Nitrogênio Total, Enxofre Total, Fósforo Orgânico e Inorgânico e razões C/S e C/N

Na tabela 6.2.2.2.1 encontram-se os dados de carbonato de cálcio, carbono orgânico, nitrogênio total, enxofre total, fósforo orgânico, fósforo inorgânico, razões C/S e C/N da região do emissário do TEBAR. Dentre os dados, estão contemplados os valores mínimo, máximo, a média, o desvio padrão do conjunto de dados e os valores do ponto controle (CTR).

Os teores de carbonato de cálcio variaram entre 24,85 a 28,12 \% $(\bar{x}=26,73 \%, s=1,07 \%)$, sendo os maiores valores encontrados nos pontos T2, T3 e T5, com 28,12 \%, 27,87 \% e 28,09 \%, respectivamente (Figura 6.2.2.2.1A). Segundo a classificação de Larsonneur et al. (1982), os pontos amostrais indicaram ambiente de sedimentação litoclástica.

As concentrações de carbono orgânico evidenciadas nos sedimentos oscilaram entre 2,39 e 3,32\% ( $\bar{x}=2,82 \%, s=0,29 \%)$. As maiores porcentagens foram obtidas nos pontos T8 e T9, com valores de 3,32 \% e 3,29 \%, respectivamente (Figura 6.2.2.2.1A).

Os resultados obtidos de nitrogênio total apresentaram pouca variação de concentração: de 0,41 a 0,59 \% ( $=0,48 \%, s=0,06 \%)$. Os maiores teores foram encontrados nos pontos T2, T6 e T9, com 0,54 \%, 0,59 \% e 0,56 \%, respectivamente (Figura 6.2.2.2.1A).

Os teores de enxofre total obtidos na região oscilaram entre 0,378 e $0,632 \%$ nos pontos 3 e 6 , respectivamente $(\bar{x}=0,51 \%, s=0,06 \%)$. Os pontos T5, T6 , T7 e T10 apresentaram as maiores concentrações desse elemento, com $0,601 \%, 0,632 \%, 0,629 \%$ e 0,601 \%, respectivamente (Figura 6.2.2.2.1B).

Os teores de fósforo total variaram de 0,064 a 0,088 \% ( $\bar{x}=0,08 \%$, $s=0,01 \%)$. A maior porcentagem foi observada no ponto T3 e a menor no ponto T7 (Figura 6.2.2.2.1B). Os teores de fósforo orgânico variaram de 0,019 a 0,043 $\%(\bar{x}=0,03 \%, s=0,01 \%)$, com maiores concentrações presentes nos pontos T2, T4 e T5, apresentando valores de 0,042 \%, 0,043 \% e 0,041 \%, respectivamente (Figura 6.2.2.2.1B). Os teores de fósforo inorgânico oscilaram entre 0,036 a $0,065 \%(\bar{x}=0,05 \%, s=0,01 \%)$, sendo as maiores concentrações evidenciadas nos pontos T6, T7 e T9, com valores de 0,056 \%, 0,056 \% e 0,065 $\%$, respectivamente (Figura 6.2.2.2.1B). 
As razões $\mathrm{C} / \mathrm{S}$ indicaram sedimento e coluna d'água óxica para os pontos amostrais T1, T3, T4, T8 e T9, variando de 6,99 a 6,49. Já nos pontos T2, T5, T7 e T10 foram observados valores de 3,98 a 4,97, indicativos de sedimento depositado sob eventos periódicos de anoxia e coluna d'água óxica (Figura 6.2.2.1B).

Os resultados das razões $\mathrm{C} / \mathrm{N}$ indicaram que a matéria orgânica dos pontos T4, T7 e T8 é de origem mista, já nos pontos T1, T2, T3, T5, T6, T9 e T10 de origem marinha (Figura 6.2.2.2.1B). 
Tabela 6.2.2.2.1 - Dados de carbonato de cálcio, carbono orgânico, nitrogênio, enxofre, fósforo orgânico, fósforo inorgânico e razões $\mathrm{C} / \mathrm{S}$ e $\mathrm{C} / \mathrm{N}$ da região do emissário do TEBAR

\begin{tabular}{cccccccccc}
\hline $\begin{array}{c}\text { Pontos } \\
\text { de } \\
\text { Coleta }\end{array}$ & $\begin{array}{cccccc}\text { CaCO3 } \\
(\%)\end{array}$ & $\begin{array}{c}\text { C org } \\
(\%)\end{array}$ & $\begin{array}{c}\mathrm{N} \\
(\%)\end{array}$ & $\begin{array}{c}\mathrm{S} \\
(\%)\end{array}$ & $\begin{array}{c}\mathrm{P} \\
(\%)\end{array}$ & $\begin{array}{c}\mathrm{P} \text { org } \\
(\%)\end{array}$ & $\begin{array}{c}\mathrm{P} \text { inorg } \\
(\%)\end{array}$ & $\mathrm{C} / \mathrm{S}$ & $\mathrm{C} / \mathrm{N}$ \\
\hline T1 & 27,00 & 2,78 & 0,52 & 0,40 & 0,076 & 0,035 & 0,041 & 6,9 & 5,3 \\
T2 & 28,12 & 2,66 & 0,54 & 0,54 & 0,084 & 0,042 & 0,042 & 5,0 & 4,9 \\
T3 & 27,87 & 2,44 & 0,41 & 0,38 & 0,064 & 0,024 & 0,040 & 6,5 & 6,0 \\
T4 & 25,27 & 2,76 & 0,42 & 0,40 & 0,079 & 0,043 & 0,036 & 7,0 & 6,6 \\
T5 & 28,09 & 2,96 & 0,51 & 0,60 & 0,086 & 0,041 & 0,045 & 4,9 & 5,8 \\
T6 & 26,72 & 2,86 & 0,59 & 0,63 & 0,084 & 0,028 & 0,056 & 4,5 & 4,8 \\
T7 & 26,94 & 2,77 & 0,44 & 0,63 & 0,088 & 0,033 & 0,056 & 4,4 & 6,3 \\
T8 & 26,39 & 3,32 & 0,44 & 0,49 & 0,082 & 0,030 & 0,052 & 6,7 & 7,5 \\
T9 & 26,08 & 3,29 & 0,56 & 0,48 & 0,084 & 0,019 & 0,065 & 6,8 & 5,9 \\
T10 & 24,85 & 2,39 & 0,41 & 0,60 & 0,074 & 0,026 & 0,047 & 4,0 & 5,8 \\
Mín. & 24,85 & 2,39 & 0,41 & 0,38 & 0,06 & 0,02 & 0,04 & - & - \\
Máx. & 28,12 & 3,32 & 0,59 & 0,63 & 0,09 & 0,04 & 0,06 & - & - \\
$\bar{x}$ & 26,73 & 2,82 & 0,48 & 0,51 & 0,08 & 0,03 & 0,05 & - & - \\
S & 1,07 & 0,29 & 0,06 & 0,09 & 0,01 & 0,01 & 0,01 & - & - \\
CTR & 14,82 & 1,80 & 0,29 & 0,36 & 0,018 & 0,005 & 0,013 & 5 & 6,2 \\
\hline
\end{tabular}




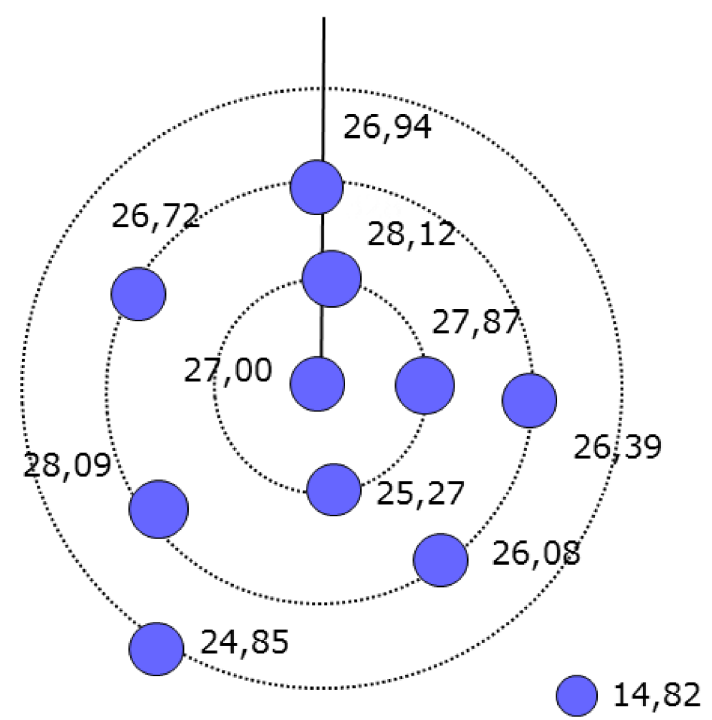

$\mathrm{CaCO}_{3}$

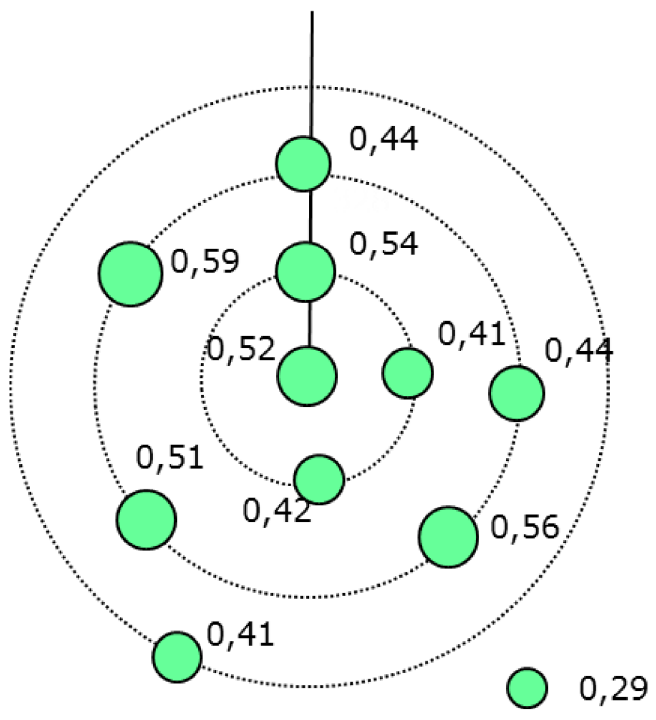

$\mathbf{N}$
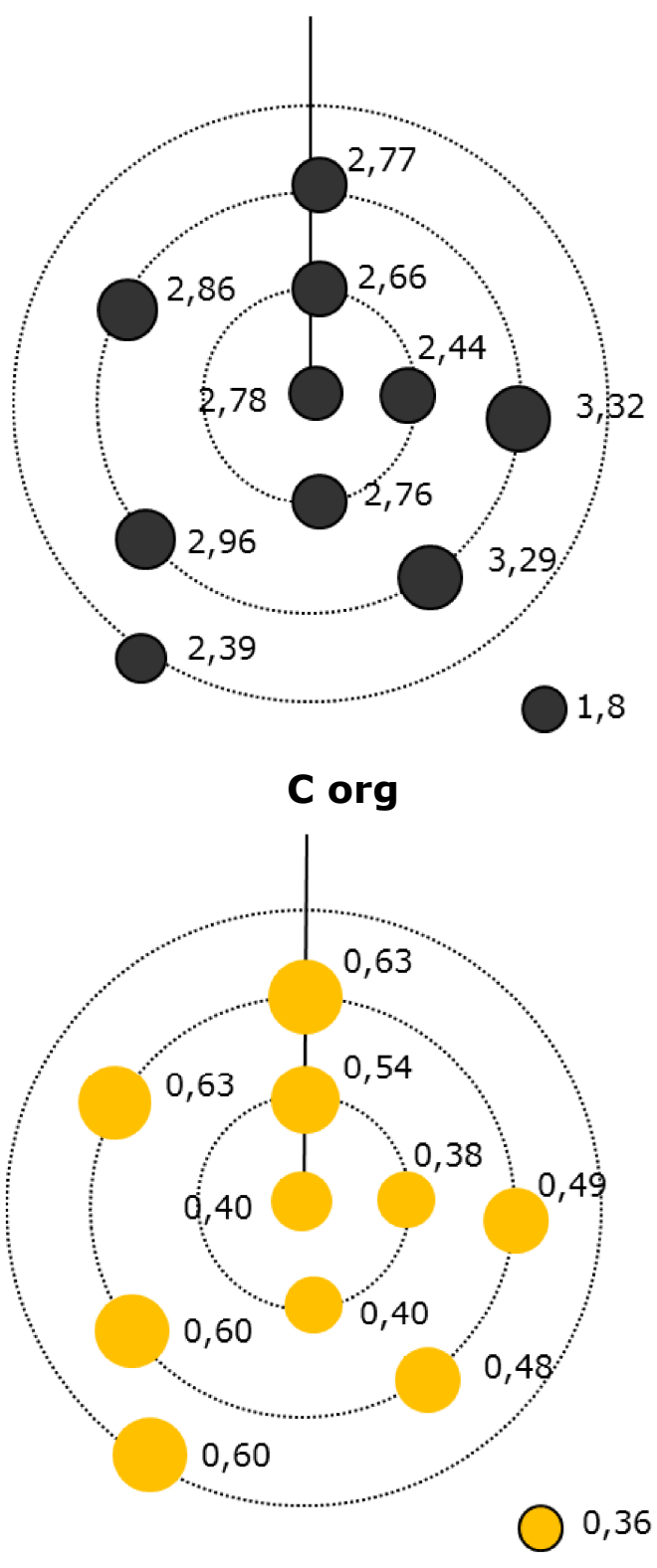

$\mathbf{S}$

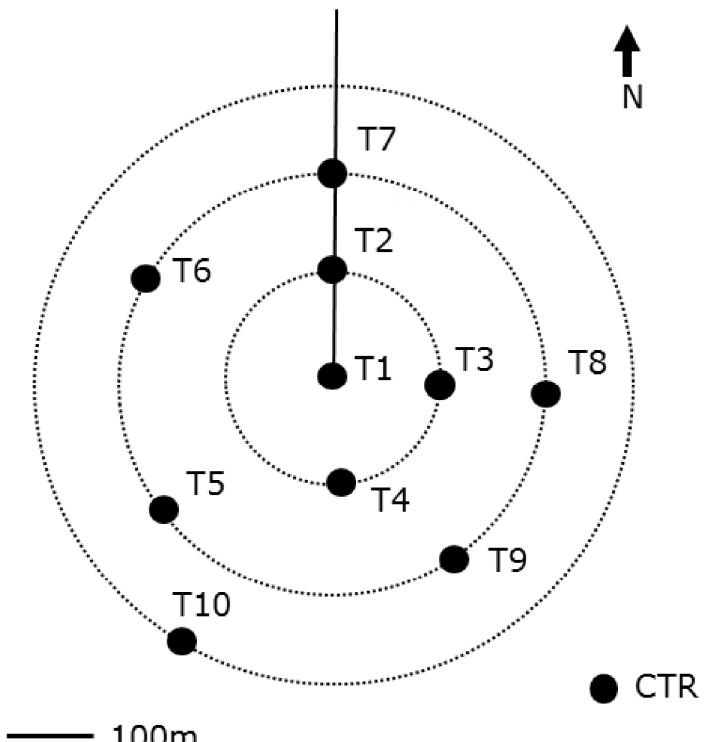

$100 \mathrm{~m}$

Figura 6.2.2.2.1A - Concentrações em \% de carbonato de cálcio, carbono orgânico, nitrogênio, enxofre e localização das amostras da região do emissário do TEBAR. 


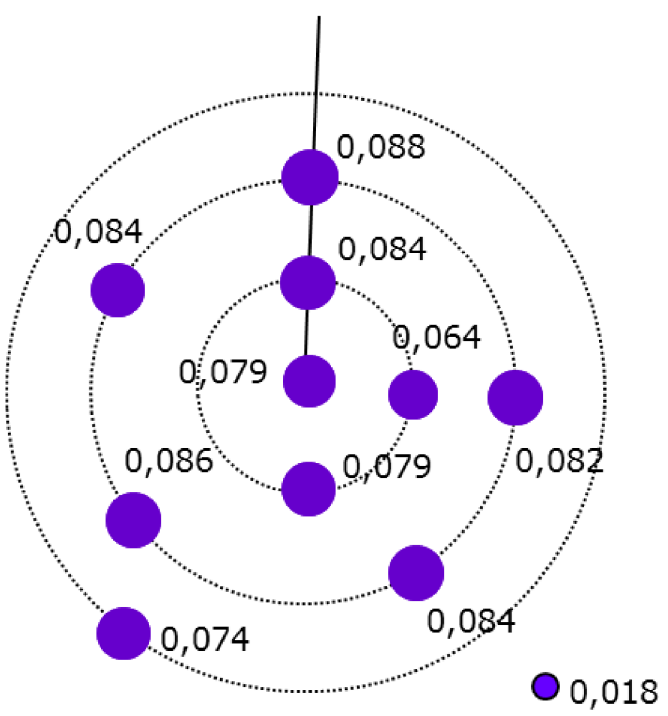

P total

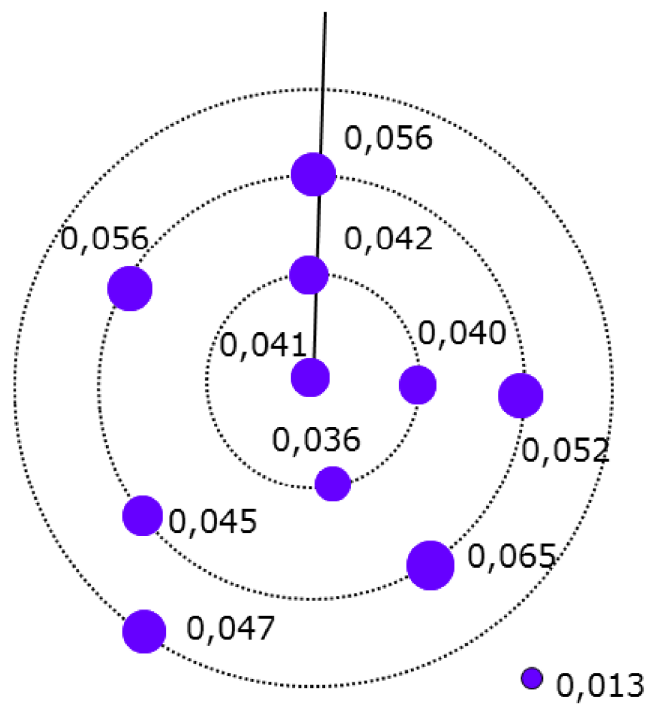

$P$ inorg

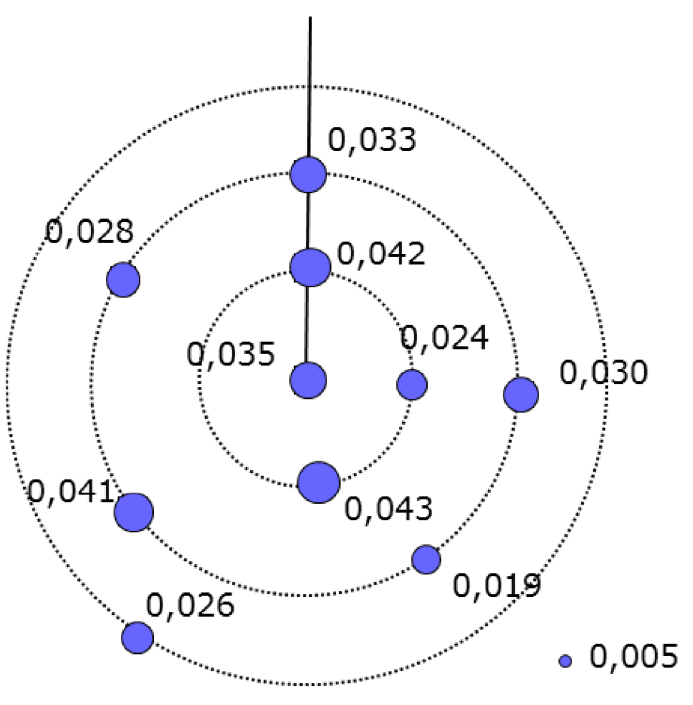

P org

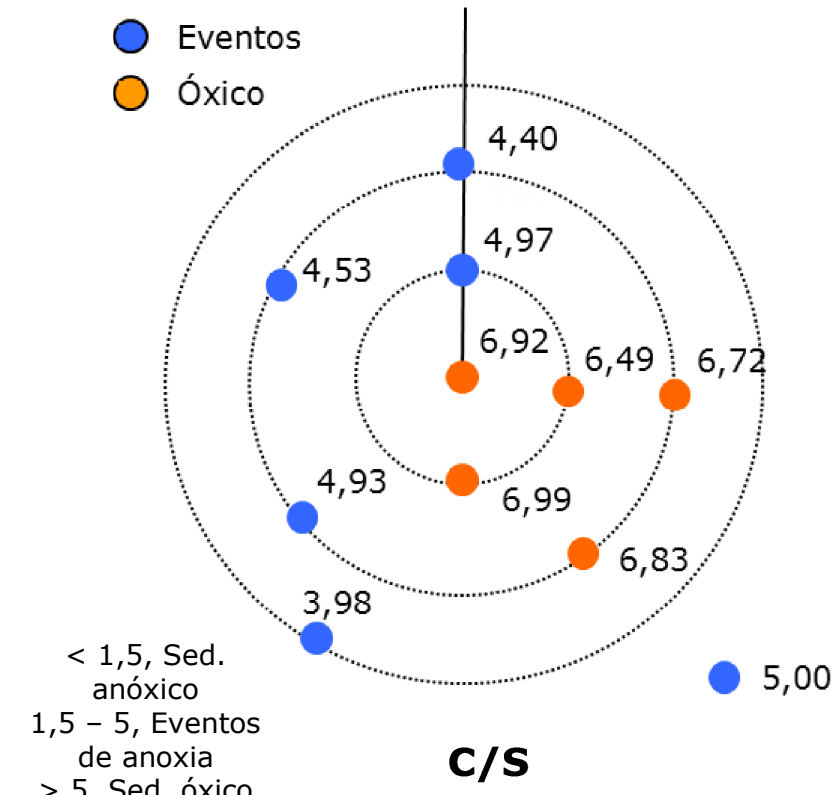

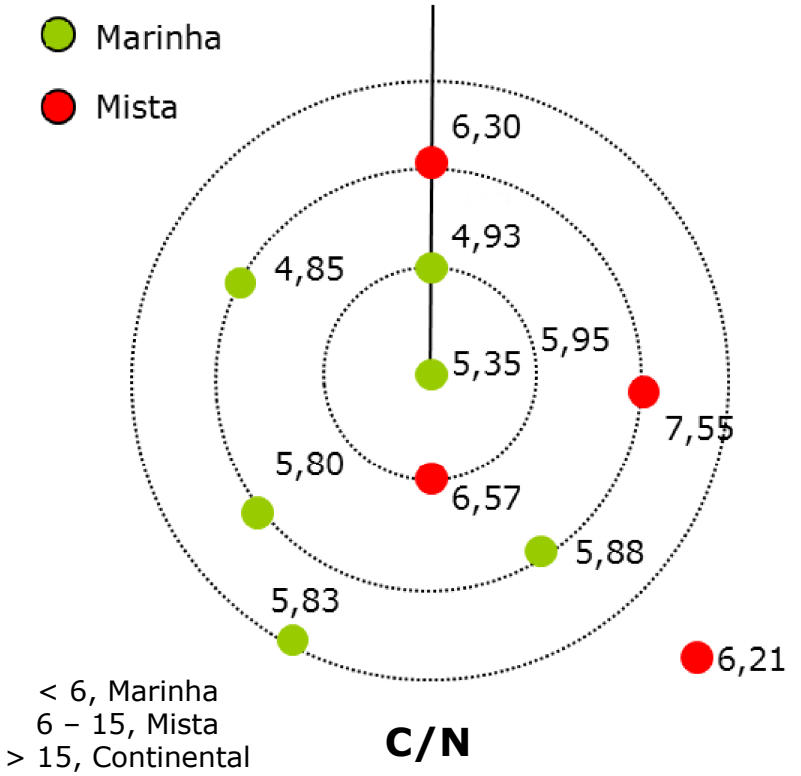

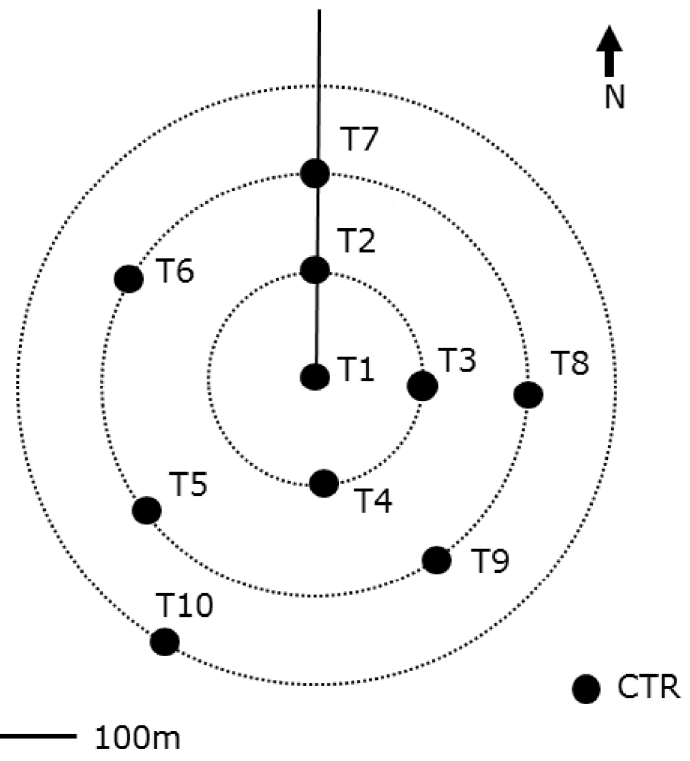

Figura 6.2 2.2.1B - Concentrações em porcentagem de fósforo total, fósforo orgânico, fósforo inorgânico, Razão C/S e C/N e localização das amostras da região do emissário do TEBAR. 


\subsection{Elementos maiores e traço contidos no sedimento}

$\mathrm{Na}$ Tabela 6.2.2.2.2A (Anexo 4), encontram-se os dados dos teores de Alumínio (Al), Arsênio (As), Bário (Ba), Cádmio (Cd), Cobalto (Co), Cromo ( $\mathrm{Cr}$ ), Cobre (Cu), Ferro (Fe), Mercúrio ( $\mathrm{Hg})$, Lítio (Li), Magnésio (Mg), Manganês (Mn), Níquel (Ni), Chumbo (Pb), Escândio (Sc), Estrôncio (Sr), Titânio (Ti), Vanádio (V) e Zinco ( $\mathrm{Zn}$ ) do emissário do TEBAR. Dentre os dados estão contemplados o limite TEL - nível limiar de efeitos "Threshold Effect Level", o limite PEL - nível provável de efeitos ("Probable Effect Level") (CCME, 2002), nível 1 - limiar abaixo do qual se prevê baixa probabilidade de efeitos adversos à biota, nível 2 limiar acima do qual se prevê um provável efeito adverso à biota (CONAMA no 344/2004), os valores máximo, mínimo, a média, o desvio padrão do conjunto de dados e os valores do ponto controle (CTR). Na Figura 6.2.2.2.2 pode-se observar, sumariamente, os dados das concentrações dos elementos supra mencionados.

Por meio da Figura 6.2.2.2.2 é possível verificar que os teores dos elementos $\mathrm{Al}, \mathrm{As}, \mathrm{Co}, \mathrm{Cr}, \mathrm{Fe}$, $\mathrm{Li}, \mathrm{Mg}, \mathrm{Ni}, \mathrm{Pb}, \mathrm{Sc}, \mathrm{Ti}, \mathrm{V}$ e $\mathrm{Zn}$ mostraram-se com baixa variabilidade entre os pontos amostrais, evidenciadas pelos valores do desvio padrão das médias encontradas (Tabela 6.2.2.2.2A). Pode-se observar, também, que as menores concentrações estão localizadas no ponto $\mathrm{T} 2$. O $\mathrm{Hg}$ e Mn apresentaram variabilidade um pouco maior que os elementos anteriores.

Para os elementos Ba e Sr, ocorreu um pico de concentração no ponto T3, enquanto para o Cd as maiores concentrações foram observadas no ponto T10.

O elemento $\mathrm{Cu}$ apresentou dois picos de concentração, nos pontos T8 e T10. Já o Sr demonstrou pico de concentração nos pontos T8 e T9, enquanto o Ti apresentou distribuição mais uniforme de valores.

Somente o As e o Cu ultrapassaram os valores guia de causa-efeito. Para o valor de TEL, o As ficou acima nos pontos T1, T2, T4, T5, T6, T7, T8, T9 e T10. E para o nível 1 nos pontos T1, T2, T3, T4, T5, T6, T7, T8 e T10. Já o Cu ficou acima de TEL nos pontos T8 e T10, e nível 1 para o ponto T10.

$\mathrm{Na}$ Tabela 6.2.2.2.2B encontram-se os valores do fator de enriquecimento (EF) para cada elemento analisado. Foi utilizado como valor de background o ponto CTR para o cálculo do EF.

Com base no ponto CTR, o elemento que obteve a classificação enriquecimento significativo foi o Ba (ponto T3), no mesmo ponto o elemento $\mathrm{Sr}$ obteve enriquecimento moderado. Já o $\mathrm{Cd}$ e o $\mathrm{Cu}$ apresentaram valores de enrquecimento moderado. 

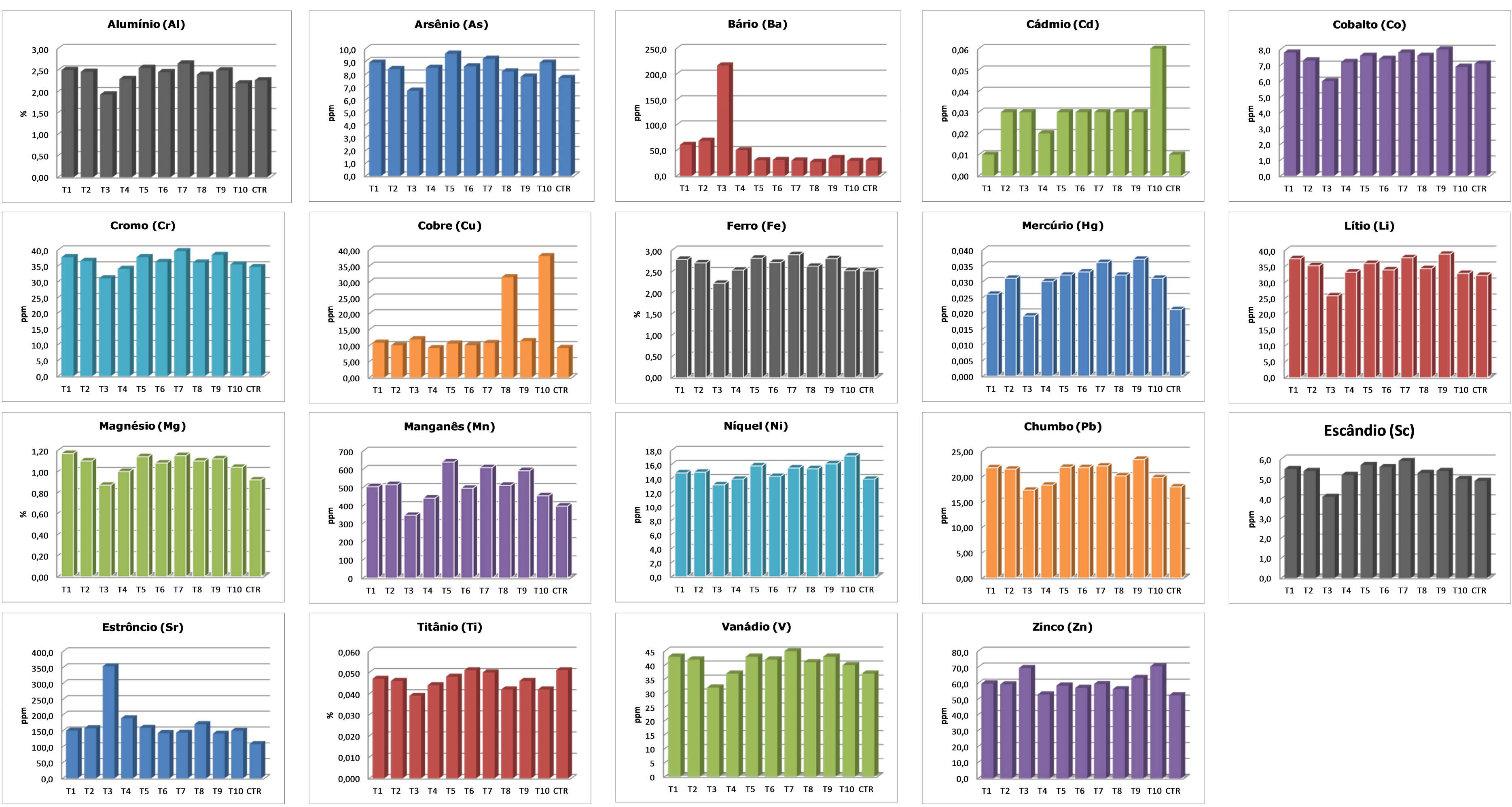

Figura 6.2.2.2.2 - Concentrações de elementos maiores e traço contidos no sedimento da região do emissário do TEBAR. 
Tabela 6.2.2.2.2B - Valores do fator de enriquecimento (EF) para os elementos maiores e traço no sedimento da região do emissário do TEBAR.

\begin{tabular}{|c|c|c|c|c|c|c|c|c|c|c|c|c|c|c|c|c|c|c|c|}
\hline $\begin{array}{l}\frac{\pi}{0} \\
\frac{0}{0} \\
0 \\
0 \\
0 \\
u \\
0 \\
\stackrel{0}{0} \\
0 \\
0\end{array}$ & 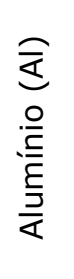 & 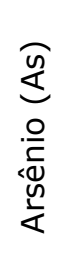 & 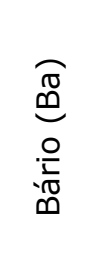 & 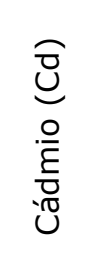 & 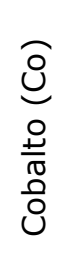 & 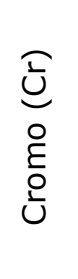 & 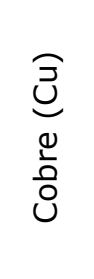 & 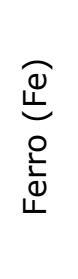 & 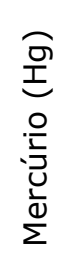 & $\begin{array}{l}\stackrel{\overbrace{}}{己} \\
\stackrel{\circ}{\stackrel{ }{\Xi}}\end{array}$ & 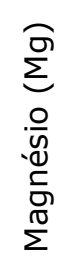 & 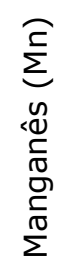 & $\begin{array}{l}\overline{\bar{z}} \\
\bar{\Phi} \\
\overline{\frac{\sigma}{z}}\end{array}$ & 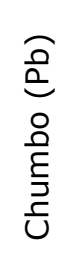 & 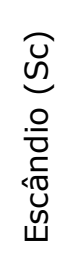 & 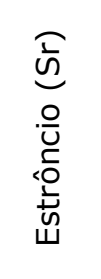 & 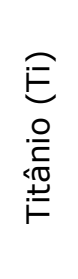 & 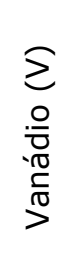 & 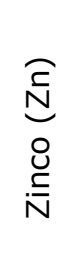 \\
\hline $\mathrm{T} 1$ & 1,0 & 1,0 & 1,8 & 0,9 & 1,0 & 1,0 & 1,1 & 1,0 & 1,1 & 1,1 & 1,1 & 1,1 & 0,9 & 1,1 & 1,0 & 1,2 & 0,8 & 1,0 & 1,0 \\
\hline $\mathrm{T} 2$ & 1,0 & 1,0 & 2,1 & $2,7+$ & 0,9 & 1,0 & 1,0 & 1,0 & 1,3 & 1,0 & 1,1 & 1,2 & 1,0 & 1,1 & 1,0 & 1,3 & 0,8 & 1,0 & 1,0 \\
\hline T3 & 1,0 & 1,0 & $8,5 \neq$ & $3,6+$ & 1,0 & 1,1 & 1,5 & 1,1 & 1,1 & 1,0 & 1,1 & 1,0 & 1,1 & 1,2 & 1,0 & $3,9+$ & 0,9 & 1,0 & 1,6 \\
\hline T4 & 1,0 & 1,0 & 1,6 & 1,9 & 1,0 & 0,9 & 0,9 & 0,9 & 1,3 & 1,0 & 1,0 & 1,0 & 0,9 & 1,0 & 1,0 & 1,7 & 0,8 & 0,9 & 1,0 \\
\hline T5 & 1,0 & 1,1 & 0,9 & $2,6+$ & 0,9 & 0,9 & 1,0 & 1,0 & 1,3 & 1,0 & 1,1 & 1,4 & 1,0 & 1,0 & 1,0 & 1,3 & 0,8 & 1,0 & 1,0 \\
\hline T6 & 0,9 & 1,0 & 0,9 & $2,6+$ & 0,9 & 0,9 & 1,0 & 0,9 & 1,4 & 0,9 & 1,0 & 1,1 & 0,9 & 1,1 & 1,0 & 1,2 & 0,9 & 1,0 & 1,0 \\
\hline T7 & 1,0 & 1,0 & 0,8 & $2,5+$ & 0,9 & 1,0 & 1,0 & 1,0 & 1,4 & 1,0 & 1,0 & 1,3 & 0,9 & 1,0 & 1,0 & 1,1 & 0,8 & 1,0 & 0,9 \\
\hline T8 & 1,0 & 1,0 & 0,8 & $2,8+$ & 1,0 & 1,0 & $3,1+$ & 1,0 & 1,4 & 1,0 & 1,1 & 1,2 & 1,0 & 1,0 & 1,0 & 1,5 & 0,8 & 1,0 & 1,0 \\
\hline Т9 & 1,0 & 0,9 & 1,0 & $2,7+$ & 1,0 & 1,0 & 1,1 & 1,0 & 1,6 & 1,1 & 1,1 & 1,4 & 1,1 & 1,2 & 1,0 & 1,2 & 0,8 & 1,1 & 1,1 \\
\hline T10 & 0,9 & 1,1 & 1,0 & $5,9 \neq$ & 1,0 & 1,0 & $4,0 \dagger$ & 1,0 & 1,4 & 1,0 & 1,1 & 1,1 & 1,2 & 1,1 & 1,0 & 1,4 & 0,8 & 1,1 & 1,3 \\
\hline
\end{tabular}

Obs.: Foi utilizado o valor do ponto CTR como background e do Sc como elemento normalizador para o cálculo.

tEnriquecimento moderado. ₹Enriquecimento significativo. 


\subsection{Análise estatística}

Na Matriz 6.2.2.2.3, encontram-se os coeficientes de Pearson para os dados de lama (silte e argila), carbonato, carbono orgânico, enxofre, nutrientes, metais e elementos-traços contidos no sedimento da região do emissário do TEBAR.

Pela Matriz de Correlação 6.2.2.2.3 pode-se verificar que os elementos Al, As, $\mathrm{Co}, \mathrm{Cr}, \mathrm{Fe}, \mathrm{Hg}$, Li, Mg, Mn, Pb, Sc, Ti e V estão correlacionados com a porcentagem de finos e o $\mathrm{P}$ total.

O Ba e Sr apresentaram correlação altamente significativa e correlação negativa com a maioria dos outros metais e elementos-traço. Já o Zn foi correlacionado negativamente somente com o $\mathrm{P}$ total. 
Matriz de Correlação 6.2.2.2.3 - Matriz de correlação exibindo os coeficientes de Pearson para os dados de lama (silte e argila), carbonato, carbono orgânico, enxofre, nutrientes, elementos maiores e traço do emissário do TEBAR.

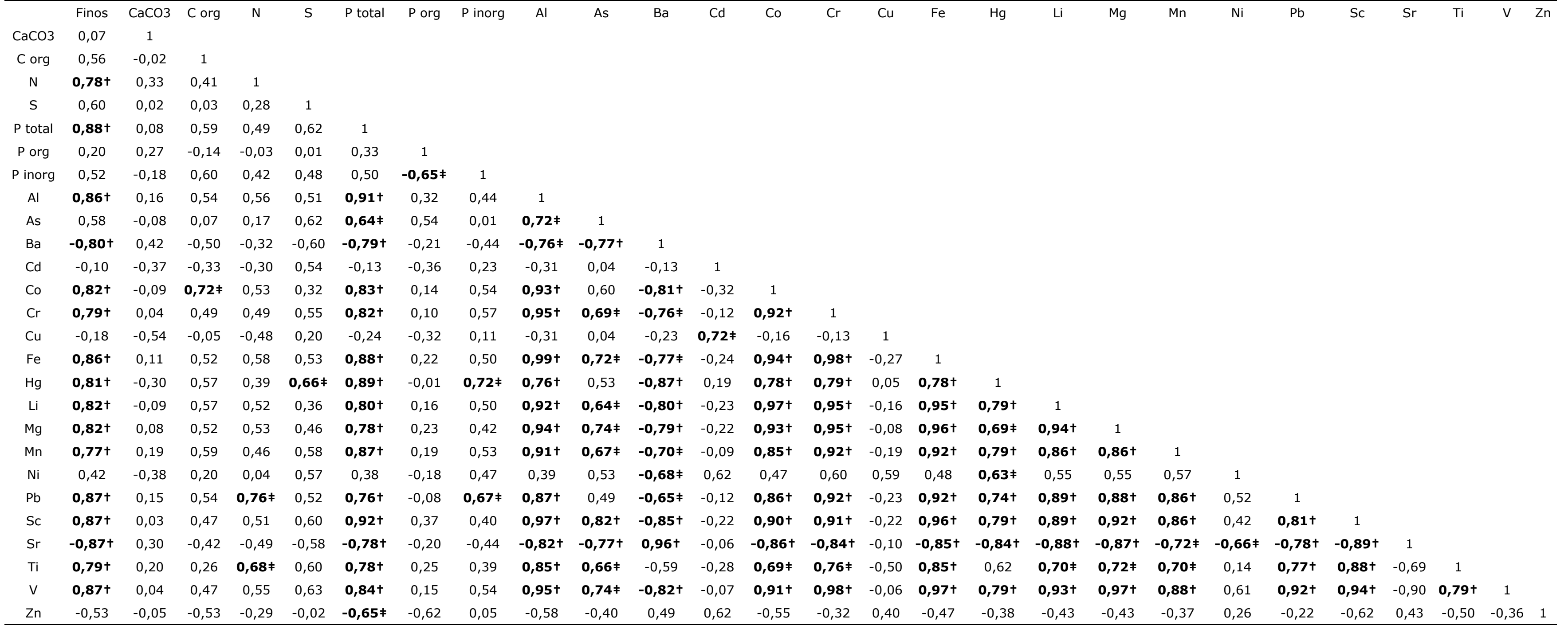

Obs. +Correlação altamente significativa para valores de $p<0,01$. $\neq$ Correlação significativa para valores $p<0,05$. (FC) - Elemento-traço carapaça corada. (F) - Elemento-traço carapaça não corada 


\subsection{ELEMENTOS-TRAÇO CONTIDOS NAS CARAPAÇAS DE FORAMINÍFEROS \\ 6.3.1 Análise qualitativa \\ 6.3.1.1 Emissário do Araçá}

No indivíduo não corado, representante da amostra coletada no ponto A2 (Figura 6.3.1.1A, detalhe 1), é possível observar, pela imagem de raio-x retroespalhada, gerada por meio do MEV (Figura 6.3.1.1A, detalhe 2), anomalias composicionais agregadas à superfície da carapaça. Nestas anomalias foram obtidas duas análises de EDS (Figura 6.3.1.1B, detalhe a b). Pode-se notar a presença dos elementos $\mathrm{Na}, \mathrm{K}, \mathrm{Ca}, \mathrm{Mg}, \mathrm{Si}, \mathrm{Cl}, \mathrm{Al}$ e $\mathrm{O}$, na primeira anomalia e os elementos $\mathrm{Na}, \mathrm{K}, \mathrm{Ca}, \mathrm{Cl}, \mathrm{Si}, \mathrm{S}, \mathrm{Mn}, \mathrm{Fe}, \mathrm{Al}$ e O, na segunda anomalia.

No representante não corado, oriundo do ponto A4 (Figura 6.3.1.1A, detalhe 3) foi visualizada, por meio da imagem retro-espalhada (Figura 6.3.1.1A, detalhe 4), uma partícula adsorvida na região dos poros (Figura 6.3.1.1A, detalhe 5). A análise EDS deste espécime (Figura 6.3.1.1B, detalhe $\mathrm{c}$ ) revelou a presença dos elementos $\mathrm{Ca}, \mathrm{Si}, \mathrm{O}, \mathrm{Cu}, \mathrm{Fe}$ e Al.

No indivíduo não corado, representante do ponto A7 (Figura 6.3.1.1A, detalhe 7), também foi observada, por meio da imagem retro-espalhada (Figura 6.3.1.1A, detalhe 8), uma partícula adsorvida próxima aos poros da carapaça (Figura 6.3.1.1A, detalhe 6). O EDS identificou, na matriz da carapaça (Figura 6.3.1.1B, detalhe $\mathrm{d}$ ), os elementos $\mathrm{Na}, \mathrm{K}$, Ca e O. Já na partícula (Figura 6.3.1.1B, detalhe e) foram identificados os elementos $\mathrm{Na}, \mathrm{K}, \mathrm{Ca}, \mathrm{Cl}, \mathrm{S}, \mathrm{Si}, \mathrm{O}, \mathrm{Cu}$, $\mathrm{Mg}, \mathrm{Fe}, \mathrm{Al}$ e Ba.

Os indivíduos corados não exibiram qualquer anômalia composicional ou partícula adsorvida. Sendo assim, não se mostraram pertinentes para realizar imagens MEV e EDS. 
1

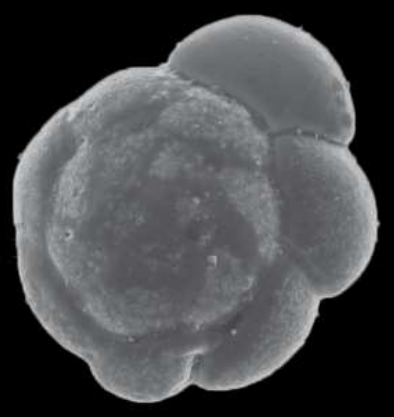

一

3

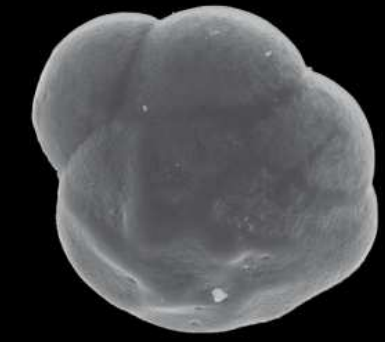

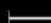

5

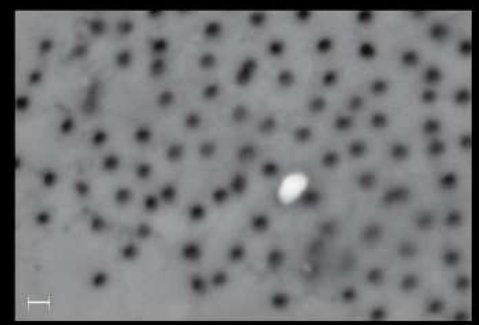

7

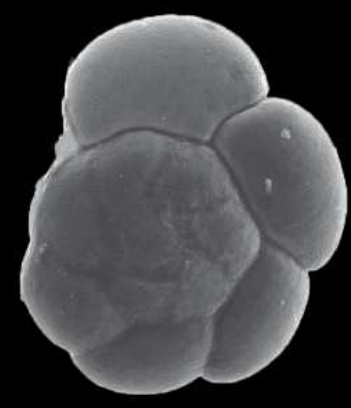

-
2

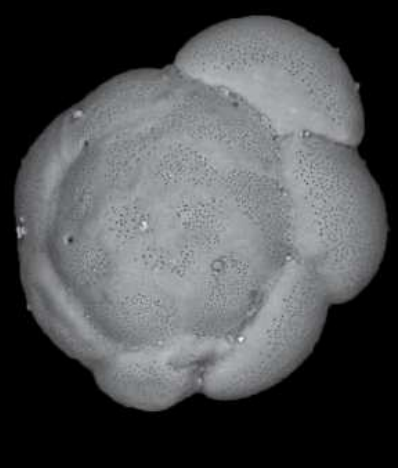

4
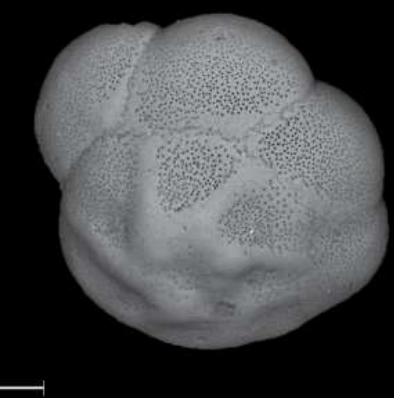

6

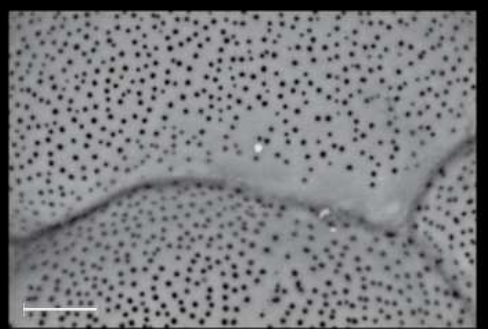

8
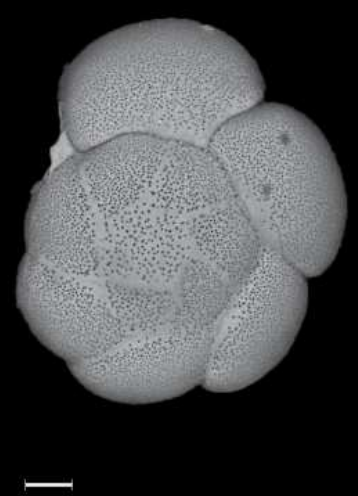

Figura 6.3.1.1A - Imagens de carapaças não coradas de $A$. tepida do emissário do Araçá.

(1) ponto $A 2$, escala $20 \mu \mathrm{m}$; (2) imagem retro-espalhado do mesmo indivíduo do ponto A2; (3) ponto A4, escala $20 \mu \mathrm{m}$; (4) imagem retro-espalhado do mesmo indivíduo do ponto A4; (5) detalhe da imagem 4 do ponto A4, partícula adsorvida, escala $1 \mu \mathrm{m}$; (6) detalhe da imagem 8 do ponto $A 7$, partícula adsorvida, escala $10 \mu \mathrm{m}$; (7) ponto A7, escala $20 \mu \mathrm{m}$; (8) imagem retroespalhado do mesmo indivíduo do ponto A7, escala $20 \mu \mathrm{m}$. 


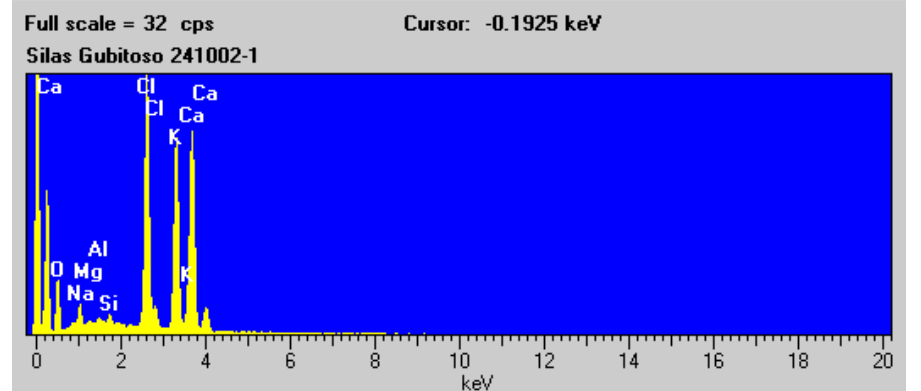

(a)

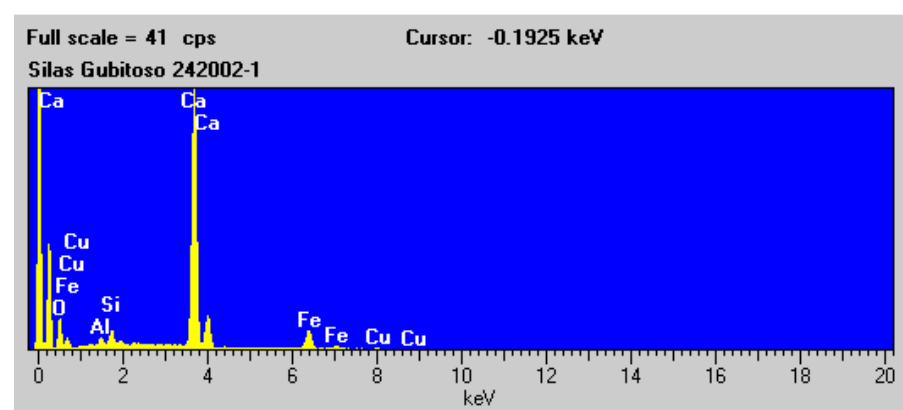

(c)

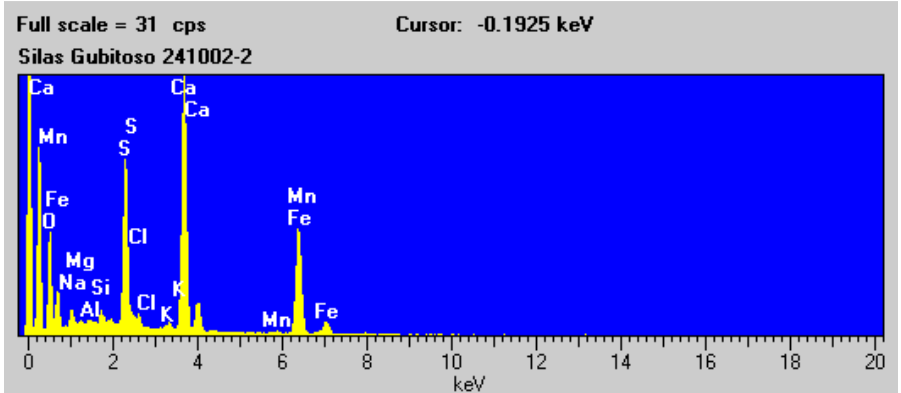

(b)

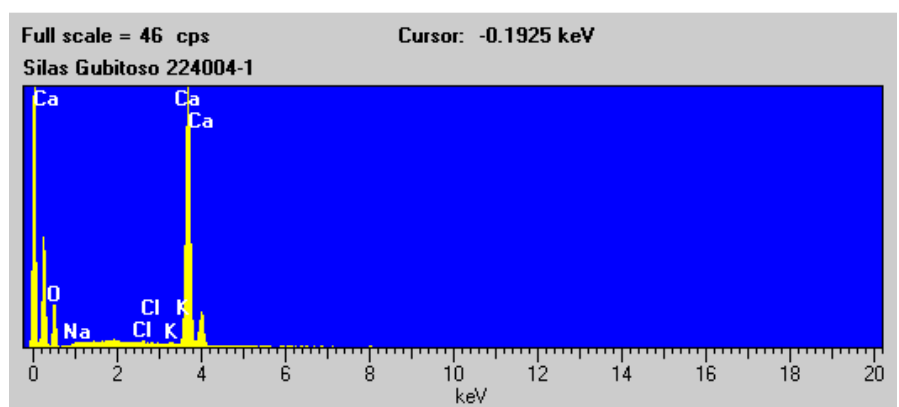

(d)

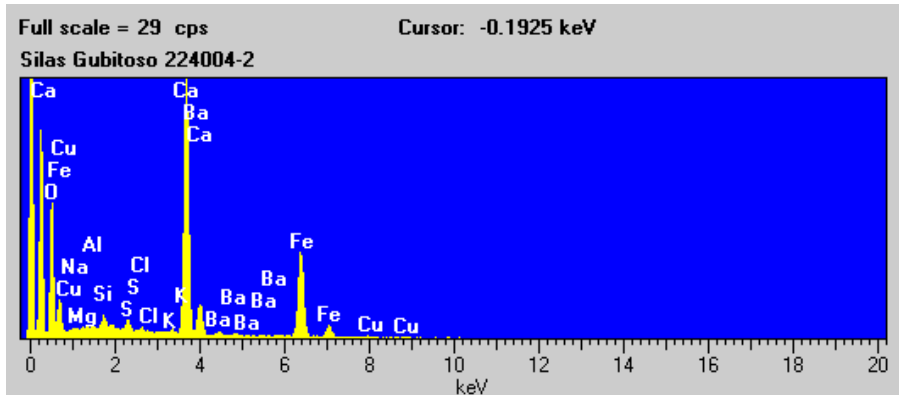

(e)

Figura 6.3.1.1B - Gráficos com as análises de EDS das carapaças não coradas de $A$. tepida.

(a) A2 detalhe I, (b) A2 detalhe II, (c) A4 detalhe, (d) A7 matriz e (e) A7 detalhe. 


\subsubsection{Emissário do TEBAR}

No indivíduo corado, representante do ponto T2 (Figura 6.3.1.2A, detalhe 1), pode-se observar, pela imagem de raio-x retro-espalhada (Figura 6.3.1.2A, detalhe 2), anomalias composicionais na superfície da carapaça. O EDS revelou, na matriz da carapaça (Figura 6.3.1.2B, detalhe a), os elementos Ca e O e na mancha composicional (Figura 6.3.1.2B, detalhe b), os elementos $\mathrm{Na}, \mathrm{K}, \mathrm{Ca}, \mathrm{Cl}$, $\mathrm{P}$ e $\mathrm{O}$.

No representante não corado do ponto T6 (Figura 6.3.1.2A, detalhe 3), também foram visualizadas, por meio da imagem retro-espalhada (Figura 6.3.1.2A, detalhe 4), anomalias composicionais. A análise EDS da matriz (Figura 6.3.1.2B, detalhe c) demonstrou a presença dos elementos $\mathrm{Ca}$ e $\mathrm{O}$, e para a mancha composicional (Figura 6.3.1.2B, detalhe d), os elementos $\mathrm{Na}, \mathrm{K}, \mathrm{Ca}, \mathrm{Cl}$ e O.

No indivíduo corado representante do ponto T7 (Figura 6.3.1.2A, detalhe $5)$, também foram verificadas, por meio da imagem retro-espalhada (Figura 6.3.1.2A, detalhe 6), anomalias composicionais. O EDS identificou, na matriz das carapaças (Figura 6.3.1.2B, detalhe e), os elementos Ca e O, e para a mancha os elementos $\mathrm{Na}, \mathrm{K}, \mathrm{Ca}, \mathrm{Cl}, \mathrm{Si}, \mathrm{Mg}$ e $\mathrm{O}$. 


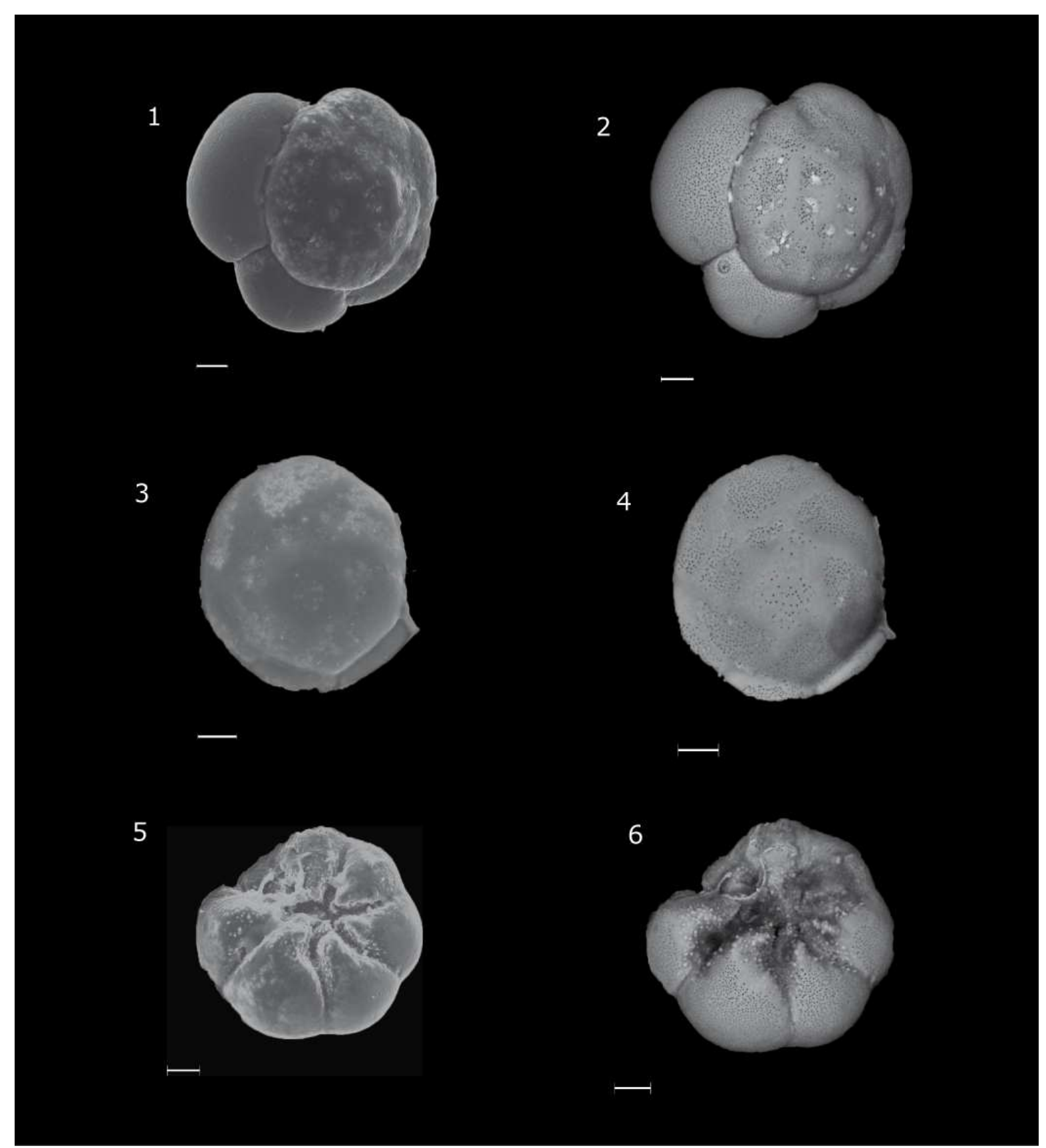

Figura 6.3.1.2A - Imagens de carapaças de $A$. tepida do emissário do TEBAR.

(1) ponto T2, corada, escala $20 \mu \mathrm{m}$; (2) imagem retro-espalhado do mesmo

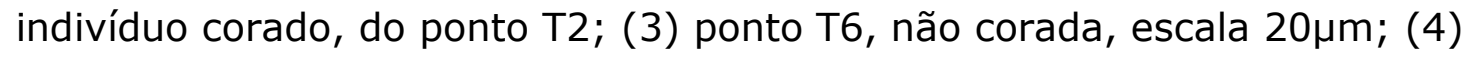
imagem retro-espalhado do mesmo indivíduo não corado do ponto T6; (5) ponto T7, corada, escala $20 \mu \mathrm{m}$; (6) imagem retro-espalhado do mesmo indivíduo corado do ponto T7. 


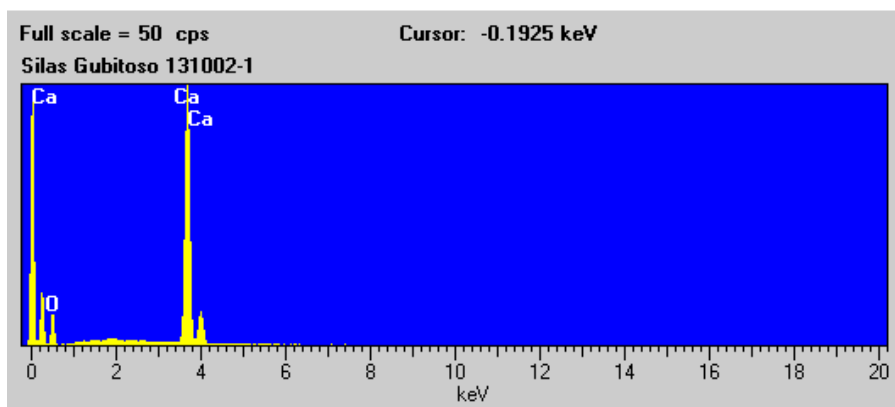

(a)

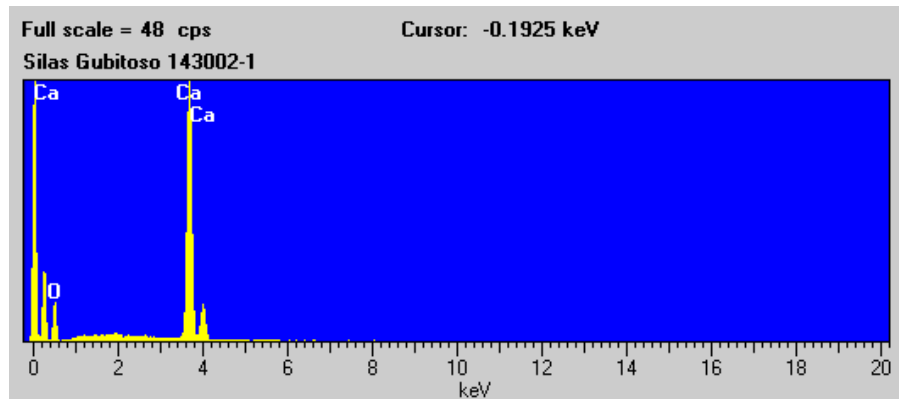

(c)

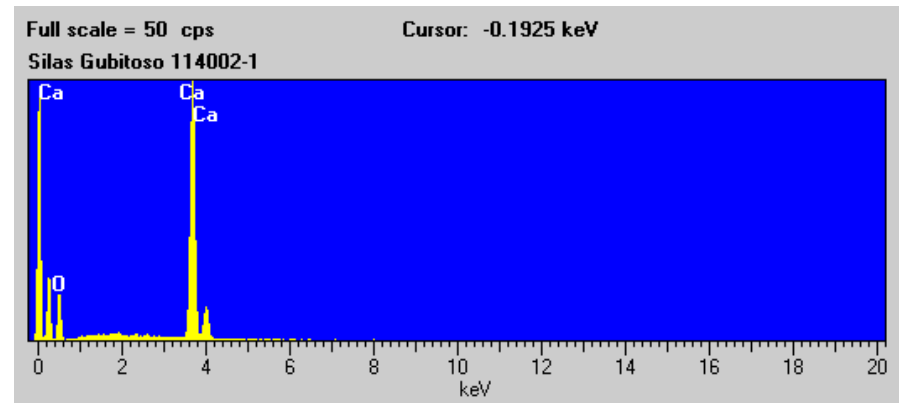

(e)

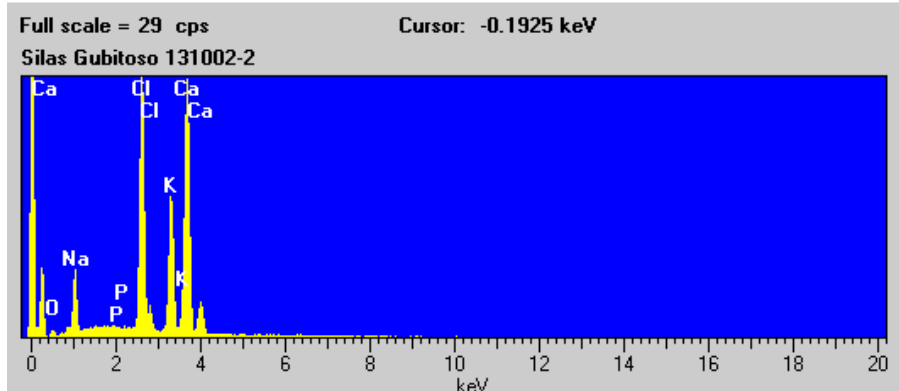

(b)

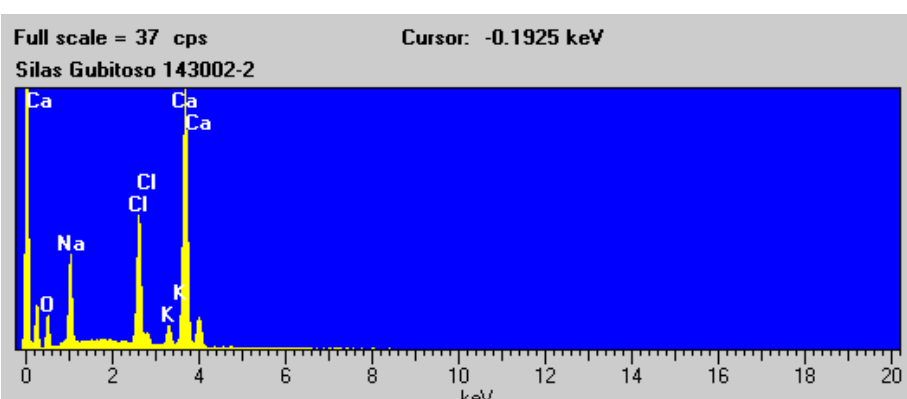

(d)

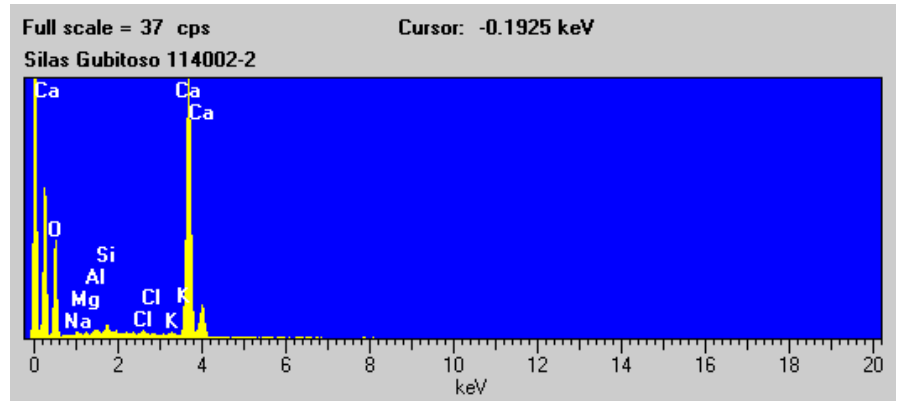

(f)

Figura 6.3.1.2B - Gráficos com as análises de EDS das carapaças de A. Tepida.

(a) T2 matriz carbonática e (b) T2 mancha composicional, carapaça corada; (c) T6 matriz carbonática e (d) T6 mancha comp., carapaça não corada; (e) T7 matriz carbonática e (f) T7 mancha comp., carapaça corada. 


\subsubsection{Análise quantitativa \\ 6.3.2.1 Araçá}

Na Tabela 6.3.2.1 (Anexo 5), estão expostos os valores das concentrações dos elementos $\mathrm{Ca}, \mathrm{Mg}, \mathrm{Sr}, \mathrm{Mn}, \mathrm{Fe}, \mathrm{Ba}, \mathrm{Zn}$ e Al, encontrados nas carapaças de $A$. tepida da região do emissário do Araçá.

A distribuição dos teores dos elementos foi representada por meio do Diagrama Boxplot 6.3.2.1.

O Ca demonstrou concentrações que variaram de 0,64 a 4,96 ppm para carapaças coradas e de 1,36 a 5,93 ppm, para não coradas. Neste contexto, houve um ligeiro acréscimo destas concentrações de carapaças coradas para as não coradas.

As concentrações de $\mathrm{Mg}$ para carapaças coradas variaram de 1,13 a 14,52 ppb (apresentando o valor de 24,49 ppb como discrepante). Entre as carapaças não coradas, as concentrações foram verificadas as maiores concentrações de Mg, variarando de 3,50 a 20,34 ppb,

Os teores de Sr oscilaram de 1,66 a 15,33 ppb para as carapaças coradas, evidenciando distribuição mais simétrica entre os valores. As não coradas variaram de 3,96 a 17,46 ppb e apresentaram acréscimo de concentração e maior variabilidade para este elemento, em relação às coradas.

Já o $\mathrm{Mn}$ apresentou valores abaixo do limite de detecção $(<0,01 \mathrm{ppb})$ para alguns pontos amostrais, i.e. A1c, A4c, A5c, A6c, A7c, A8c, A9c, A10c, A3, A4 e A10. Os valores de concentração variaram de 0,72 a $6,75 \mathrm{ppb}$ para as carapaças coradas. As não coradas revelaram valores de 0,19 a 2,51 ppb e exibiram o valor de 6,83 ppb como discrepante para este elemento.

Os teores de Fe para as coradas oscilaram de 0,70 a 12,16, apresentando o valor de 24,45 ppb como discrepante e uma distribuição simétrica do restante dos valores. Já nas não coradas, os valores deste elemento, oscilaram de 2,52 a 26,03 ppb, exibindo uma maior distribuição e concetração que as coradas.

A concentração de Ba foi a menor entre todos todos os elementos estudados e variou de 0,04 a 0,23 ppb para as carapaças coradas e de 0,02 a $0,21 \mathrm{ppb}$, para as não coradas.

O Zn demonstrou valores de 0,51 a 2,40 ppb para as carapaças coradas. Para as não coradas, os valores foram de 0,72 a 4,03 ppb, com o valor discrepante de 5,19 ppb. 
O Al variou de 1,34 a 5,03 ppb para as carapaças coradas, de 1,32 a 6,22 ppb para as não corados, apresentando valores discrepante de 10,81 e 12, 37 ppb, respectivamente.

Foram realizadas duas matrizes de correlação, exibindo os coeficientes de Pearson, para os dado do emissário do Araçá. Uma para os dados de metais e elementos-traços contidos no sedimento com os elementos-traços contidos nas carapaças de foraminíferos (6.3.2.1A). E outra somente para os elementostraços contidos nas carapaças (6.3.2.1B).

$\mathrm{O} \mathrm{Cr}$ do sedimento demonstrou correlação com o $\mathrm{Mg}, \mathrm{Fe}, \mathrm{Ba}$ e $\mathrm{Al}$ das carapaças coradas. Já o Ti do sedimento exibiu correlação negativa com Fe, Ba e Al das carapaças coradas.

O Zn das carapaças não coradas exibiu correlação com o Al, Co, Li, Mg, $\mathrm{Mn}, \mathrm{Ni}, \mathrm{Pb}, \mathrm{V}$ e $\mathrm{Zn}$ encontrados no sedimento.

No geral, verificou-se correlação entre o $\mathrm{Ca}, \mathrm{Mg}, \mathrm{Sr}, \mathrm{Fe}, \mathrm{Ba}$ e $\mathrm{Al}$ das carapaças coradas (organismos vivos) e entre o Ca e $\mathrm{Sr}$ e $\mathrm{Mg}, \mathrm{Mn}, \mathrm{Al}$ e $\mathrm{Ba}$ das carapaças não coradas (organismos mortos).

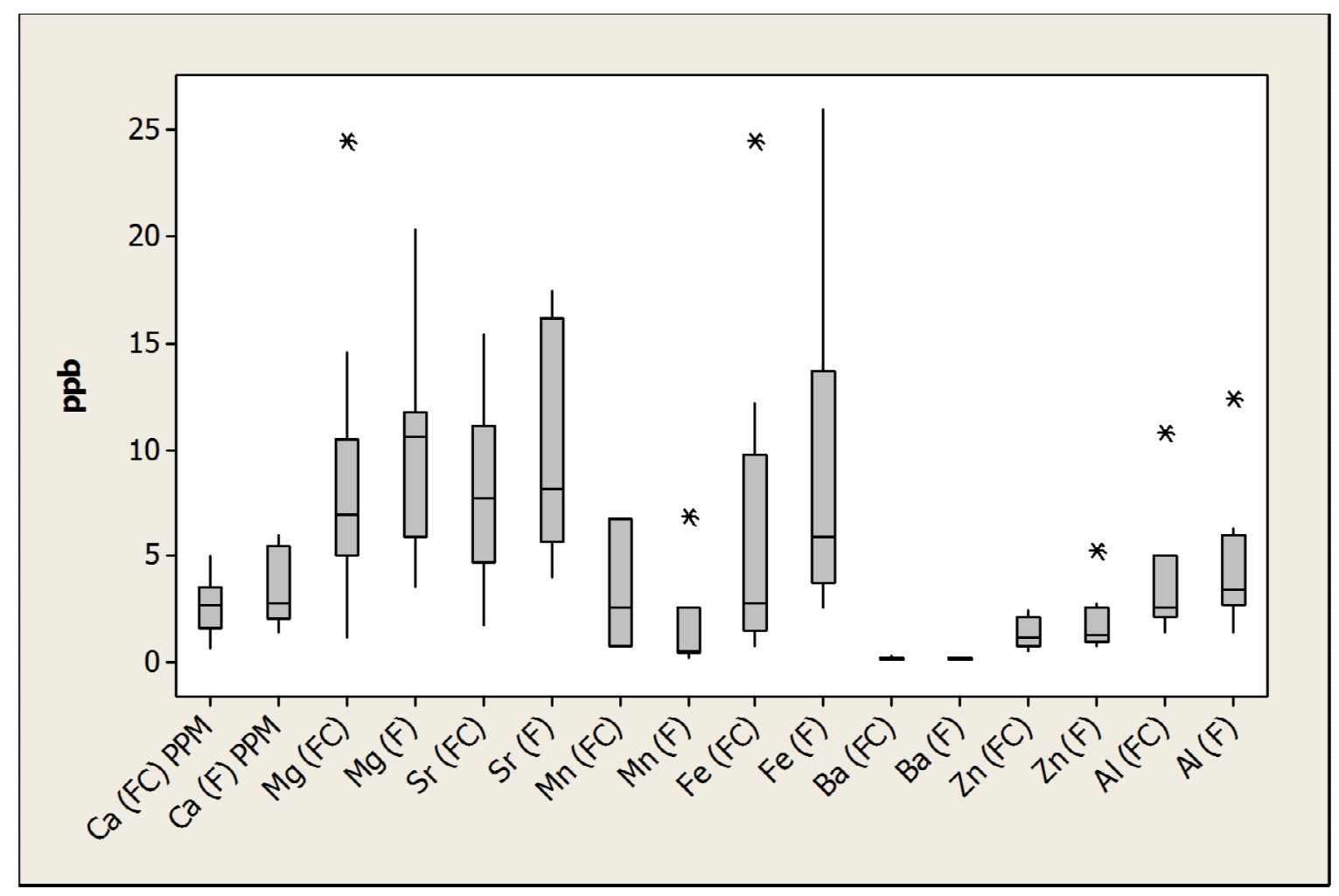

Diagrama Boxplot 6.3.2.1 - Elementos-traço em ppb das carapaças de A. tepida da região do emissário do Araçá.

Obs.: Os valores de Ca estão representados em ppm, FC - carapaças coradas e F - carapaças não coradas. 
Matriz 6.3.2.1A - Matriz de correlação exibindo os coeficientes de Pearson para os elementos maiores e traço contidos no sedimento com elementos-traços das carapaças de foraminíferos do emissário do Araçá.

\begin{tabular}{|c|c|c|c|c|c|c|c|c|c|c|c|c|c|c|c|c|c|c|c|}
\hline & Al & As & $\mathrm{Ba}$ & $\mathrm{Cd}$ & Co & $\mathrm{Cr}$ & $\mathrm{Cu}$ & $\mathrm{Fe}$ & $\mathrm{Hg}$ & $\mathrm{Li}$ & $\mathrm{Mg}$ & $M n$ & $\mathrm{Ni}$ & $\mathrm{Pb}$ & Sc & $\mathrm{Sr}$ & $\mathrm{Ti}$ & V & $\mathrm{Zn}$ \\
\hline $\mathrm{Ca}(\mathrm{FC})$ & 0,04 & $-0,04$ & $-0,36$ & 0,19 & 0,04 & 0,33 & 0,39 & $-0,06$ & 0,04 & 0,07 & 0,01 & 0,08 & 0,09 & 0,15 & 0,08 & $-0,21$ & $-0,01$ & $-0,03$ & 0,11 \\
\hline $\mathrm{Mg}(\mathrm{FC})$ & $-0,27$ & $-0,36$ & $-0,57$ & $-0,08$ & $-0,38$ & $0,81+$ & 0,14 & $-0,41$ & $-0,20$ & $-0,29$ & $-0,36$ & $-0,22$ & $-0,27$ & $-0,21$ & $-0,39$ & $-0,09$ & $-0,56$ & $-0,30$ & $-0,42$ \\
\hline $\mathrm{Sr}(\mathrm{FC})$ & 0,03 & $-0,06$ & $-0,35$ & 0,19 & 0,03 & 0,36 & 0,40 & $-0,06$ & 0,04 & 0,07 & 0,00 & 0,07 & 0,08 & 0,15 & 0,07 & $-0,21$ & $-0,02$ & $-0,03$ & 0,11 \\
\hline $\mathrm{Fe}(\mathrm{FC})$ & $-0,27$ & $-0,34$ & $-0,60$ & $-0,25$ & $-0,42$ & $0,82+$ & 0,07 & $-0,40$ & $-0,24$ & $-0,32$ & $-0,37$ & $-0,21$ & $-0,29$ & $-0,25$ & $-0,45$ & 0,09 & $-0,75 \neq$ & $-0,27$ & $-0,51$ \\
\hline $\mathrm{Ba}(\mathrm{FC})$ & 0,07 & $-0,13$ & $-0,68 \neq$ & 0,00 & $-0,12$ & $0,77+$ & 0,20 & $-0,12$ & 0,05 & $-0,01$ & $-0,03$ & 0,04 & 0,08 & 0,14 & $-0,10$ & 0,28 & $-0,64 \neq$ & 0,03 & $-0,14$ \\
\hline $\mathrm{Zn}(\mathrm{FC})$ & $-0,49$ & $-0,64 \neq$ & $-0,07$ & 0,64 & $-0,49$ & 0,32 & 0,31 & $-0,57$ & 0,29 & $-0,52$ & $-0,57$ & $-0,57$ & $-0,48$ & $-0,37$ & $-0,44$ & $-0,62$ & 0,15 & $-0,54$ & $-0,13$ \\
\hline Al FC) & $-0,13$ & $-0,23$ & $-0,55$ & $-0,67$ & $-0,31$ & $0,94 \dagger$ & $-0,08$ & $-0,27$ & $-0,25$ & $-0,20$ & $-0,24$ & $-0,11$ & $-0,16$ & $-0,13$ & $-0,35$ & 0,25 & $-0,83+$ & $-0,13$ & $-0,47$ \\
\hline $\mathrm{Ca}(\mathrm{F})$ & $-0,33$ & $-0,25$ & 0,38 & 0,01 & $-0,31$ & $-0,29$ & $-0,16$ & $-0,24$ & 0,11 & $-0,31$ & $-0,29$ & $-0,30$ & $-0,25$ & $-0,34$ & $-0,37$ & 0,10 & $-0,01$ & $-0,21$ & $-0,30$ \\
\hline $\mathrm{Mg}(\mathrm{F})$ & $-0,31$ & $-0,27$ & $-0,21$ & $-0,22$ & $-0,43$ & 0,13 & $-0,18$ & $-0,30$ & $-0,15$ & $-0,34$ & $-0,36$ & $-0,26$ & $-0,32$ & $-0,37$ & $-0,47$ & 0,35 & $-0,57$ & $-0,19$ & $-0,50$ \\
\hline $\operatorname{Sr}(F)$ & $-0,30$ & $-0,23$ & 0,35 & $-0,03$ & $-0,30$ & $-0,27$ & $-0,14$ & $-0,21$ & 0,11 & $-0,29$ & $-0,27$ & $-0,28$ & $-0,23$ & $-0,31$ & $-0,35$ & 0,14 & $-0,05$ & $-0,18$ & $-0,29$ \\
\hline$M n(F)$ & 0,26 & 0,20 & $-0,28$ & $-0,68$ & 0,16 & 0,32 & $-0,19$ & 0,26 & $-0,27$ & 0,27 & 0,14 & 0,33 & 0,22 & 0,18 & 0,13 & 0,53 & $-0,49$ & 0,36 & $-0,09$ \\
\hline $\mathrm{Fe}(\mathrm{F})$ & $-0,03$ & $-0,01$ & $-0,07$ & $-0,31$ & $-0,10$ & $-0,24$ & $-0,27$ & 0,03 & $-0,06$ & $-0,05$ & $-0,05$ & $-0,03$ & $-0,07$ & $-0,12$ & $-0,10$ & 0,40 & $-0,21$ & 0,08 & $-0,15$ \\
\hline $\mathrm{Ba}(\mathrm{F})$ & $-0,36$ & $-0,28$ & $-0,24$ & 0,01 & $-0,39$ & $-0,18$ & $-0,06$ & $-0,33$ & $-0,15$ & $-0,36$ & $-0,37$ & $-0,32$ & $-0,44$ & $-0,44$ & $-0,37$ & $-0,01$ & $-0,14$ & $-0,31$ & $-0,34$ \\
\hline $\mathrm{Zn}(\mathrm{F})$ & $0,71 \neq$ & 0,53 & $-0,08$ & $-0,07$ & $0,66 \neq$ & 0,12 & 0,20 & 0,63 & 0,18 & $0,68 \neq$ & $0,67 \neq$ & $0,65 \neq$ & $0,72 \neq$ & $0,79+$ & $0,70 \neq$ & 0,18 & 0,00 & $0,65 \neq$ & $0,69 \neq$ \\
\hline $\mathrm{Al}(\mathrm{F})$ & 0,11 & 0,15 & 0,02 & $-0,38$ & 0,08 & $-0,20$ & $-0,11$ & 0,18 & $-0,11$ & 0,11 & 0,07 & 0,14 & 0,07 & 0,01 & 0,06 & 0,38 & $-0,11$ & 0,22 & 0,02 \\
\hline
\end{tabular}

Obs. +Correlação altamente significativa para valores de $p<0,01$. ₹Correlação significativa para valores $p<0,05$. (FC) - Elemento-traço carapaça corada. (F) - Elemento-traço carapaça não corada 
Matriz 6.3.2.1B - Matriz de correlação exibindo os coeficientes de Pearson para os dados de elementos-traços das carapaças de foraminíferos do emissário do Araçá.

\begin{tabular}{|c|c|c|c|c|c|c|c|c|c|c|c|c|c|c|c|}
\hline & $\mathrm{Ca}(\mathrm{FC})$ & $\mathrm{Mg}(\mathrm{FC})$ & $\mathrm{Sr}(\mathrm{FC})$ & $\mathrm{Fe}(\mathrm{FC})$ & $\mathrm{Ba}(\mathrm{FC})$ & $\mathrm{Zn}(\mathrm{FC})$ & $\mathrm{Al}(\mathrm{FC})$ & $\mathrm{Ca}(\mathrm{F})$ & $\mathrm{Mg}(\mathrm{F})$ & $\operatorname{Sr}(F)$ & $M n(F)$ & $\mathrm{Fe}(\mathrm{F})$ & $\mathrm{Ba}(\mathrm{F})$ & $\mathrm{Zn}(\mathrm{F})$ & Al $(F)$ \\
\hline $\mathrm{Ca}(\mathrm{FC})$ & 1 & & & & & & & & & & & & & & \\
\hline $\mathrm{Mg}(\mathrm{FC})$ & $0,68 \neq$ & 1 & & & & & & & & & & & & & \\
\hline $\operatorname{Sr}(F C)$ & $1+$ & $0,71 \neq$ & 1 & & & & & & & & & & & & \\
\hline $\mathrm{Fe}(\mathrm{FC})$ & 0,46 & $0,94 \dagger$ & 0,48 & 1 & & & & & & & & & & & \\
\hline $\mathrm{Ba}(\mathrm{FC})$ & 0,44 & $0,69 \neq$ & 0,45 & $0,66 \neq$ & 1 & & & & & & & & & & \\
\hline $\mathrm{Zn}(\mathrm{FC})$ & 0,08 & 0,33 & 0,12 & 0,22 & 0,31 & 1 & & & & & & & & & \\
\hline Al FC) & 0,20 & $0,80 \neq$ & 0,23 & $0,89+$ & $0,79 \neq$ & 0,31 & 1 & & & & & & & & \\
\hline $\mathrm{Ca}(\mathrm{F})$ & $-0,31$ & $-0,18$ & $-0,32$ & $-0,10$ & $-0,26$ & $-0,33$ & $-0,07$ & 1 & & & & & & & \\
\hline$M g(F)$ & $-0,35$ & 0,18 & $-0,33$ & 0,44 & $-0,09$ & $-0,28$ & 0,36 & 0,56 & 1 & & & & & & \\
\hline $\operatorname{Sr}(F)$ & $-0,33$ & $-0,17$ & $-0,32$ & $-0,07$ & $-0,27$ & $-0,35$ & $-0,05$ & $1+$ & 0,61 & 1 & & & & & \\
\hline$M n(F)$ & $-0,27$ & 0,21 & $-0,21$ & 0,38 & $-0,06$ & $-0,24$ & 0,36 & 0,22 & $0,96+$ & 0,29 & 1 & & & & \\
\hline $\mathrm{Fe}(\mathrm{F})$ & $-0,75$ & $-0,40$ & $-0,74 \neq$ & $-0,15$ & $-0,43$ & $-0,28$ & $-0,09$ & 0,35 & $0,73 \neq$ & 0,40 & $0,76 \neq$ & 1 & & & \\
\hline $\mathrm{Ba}(\mathrm{F})$ & $-0,25$ & 0,00 & $-0,25$ & 0,20 & $-0,37$ & $-0,06$ & $-0,05$ & $-0,05$ & 0,62 & $-0,01$ & 0,55 & $0,65 \neq$ & 1 & & \\
\hline $\mathrm{Zn}(\mathrm{F})$ & $-0,07$ & $-0,27$ & $-0,06$ & $-0,29$ & 0,05 & $-0,02$ & $-0,12$ & $-0,54$ & $-0,47$ & $-0,53$ & $-0,21$ & $-0,10$ & $-0,35$ & 1 & \\
\hline Al (F) & $-0,39$ & $-0,20$ & $-0,37$ & 0,01 & $-0,50$ & $-0,40$ & $-0,10$ & 0,32 & $0,74 \neq$ & 0,39 & $0,88+$ & $0,82+$ & $0,67 \neq$ & $-0,18$ & 1 \\
\hline
\end{tabular}

Obs. +Correlação altamente significativa para valores de $p<0,01$. $¥$ Correlação significativa para valores $p<0,05$. (FC) - Elemento-traço carapaça corada. (F) - Elemento-traço carapaça não corada 


\subsubsection{TEBAR}

Na Tabela 6.3.2.2 (Anexo 6), encontram-se discriminados os valores das concentrações dos elementos $\mathrm{Ca}, \mathrm{Mg}, \mathrm{Sr}, \mathrm{Mn}, \mathrm{Fe}, \mathrm{Ba}, \mathrm{Zn}$ e Al, evidenciados nas carapaças de $A$. tepida, na região do emissário do TEBAR.

A distribuição dos teores dos elementos foi representada por meio do Diagrama Boxplot 6.3.2.2.

As concentrações de Ca variaram de 0,19 a 1,66 ppm para as carapaças coradas. As não coradas exibiram concentrações maiores e variaram de 0,73 a 2,22 ppm.

Para o $\mathrm{Mg}$ as concentrações variaram de 0,05 a 4,11 ppb para as carapaças coradas. As carapaças não coradas também apresentaram valores mais elevados que as coradas (entre 1,52 e 5,60 ppb).

O Sr também exibiu valores menores para as carapaças coradas que as não coradas. As concetrações oscilaram de 0,35 a 5,16 ppb para as carapaças coradas e de 1,89 a 6,78 ppb, para as não coradas.

Os valores de concentração de Mn ficaram abaixo do limite de detecção, $i$. e. $<0,01 \mathrm{ppb}$, para a quase totalidade dos pontos. Entre as carapaças não coradas, apenas o ponto T8 apresentou o valor de 0,58 ppb.

Os teores de Fe oscilaram de 0,25 a 3,25 ppb para as carapaças coradas. Apresentado valores maiores, as não coradas, oscilaram de 1,16 a 6,50 ppb.

A concentração de $\mathrm{Ba}$ refletiram os menores teores identificados dos elementos analisados e variaram de 0,01 a 0,15, com o valor discrepante de 0,23 ppb para as carapaças coradas. Para as não coradas, houve variação de 0,01 a $24 \mathrm{ppb}$, exibindo o valor de 0,70 ppb como discreante.

O Zn apresentou maior variabilidade dos dados paras as carapaças coradas, com valores de 0,36 a 9,37 ppb. As não coradas variaram de 0,50 a 6,25 ppb, com o valor de 24,26 para discrepante.

O Al variou de 0,47 a 3,62 ppb para as carapaças coradas. As não coradas tiveram distribuição simétrica para as concentrações de $\mathrm{Al}$, que variaram de 0,74 a 3,62 ppb.

Foram realizadas duas matrizes de correlação, exibindo os coeficientes de Pearson, para os dados do emissário do TEBAR. Uma para os dados de metais e elementos-traços presentes no sedimento com os elementos-traço contidos nas 
carapaças de foraminíferos (Matriz 6.3.2.2A) e outra somente para os elementos-traço contidos nas carapaças (Matriz 6.3.2.2B).

O carbono orgânico, nitrogênio e o fósforo inorgânico do sedimento exibiram correlações com o $\mathrm{Ca}, \mathrm{Mg}$, Sr, Fe e Zn das carapaças coradas de foraminíferos.

Em relaçao ao elementos do sedimento com as carapaças coradas, o Co foi correlato ao $\mathrm{Ca}, \mathrm{Mg}$ e Sr das carapaças. Já o Pb exibiu corelação com o Ca, Mg, $\mathrm{Sr}$ e $\mathrm{Fe}$ das carapaças. O $\mathrm{Cr}$ com o $\mathrm{Zn}$ das carapaças e o $\mathrm{Mn}$ com o Fe das carapaças.

Os elementos do sedimento que apresentaram correlação com os foraminíferos não coradados foram o As, Sc, Ti, Ni e Zn.

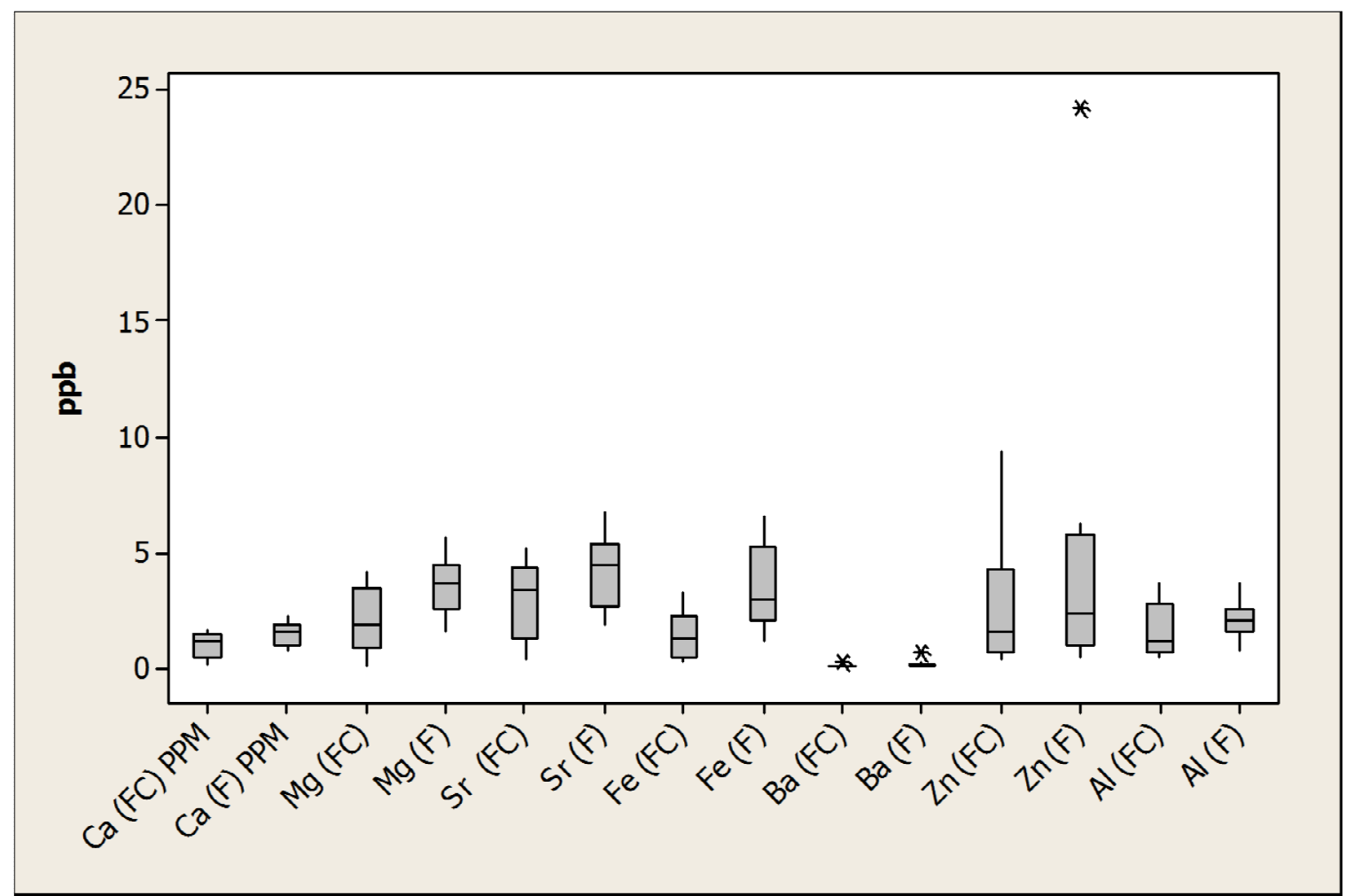

Diagrama Boxplot 6.3.2.2 - Elementos-traço em ppb das carapaças de A. tepida da região do emissário do TEBAR.

Obs.: Os valores de Ca estão representados em ppm, FC - carapaças coradas e F - carapaças não coradas. 
Matriz 6.3.2.2A - Matriz de correlação exibindo os coeficientes de Pearson para os elementos maiores e traço do sedimento e elementos-traços das carapaças de foraminíferos do emissário do TEBAR.

\begin{tabular}{|c|c|c|c|c|c|c|c|c|c|c|c|c|c|c|c|c|c|c|c|c|c|c|c|}
\hline & $\mathrm{CaCO} 3$ & C org & $N$ & $P$ inorg & $\mathrm{Al}$ & As & $\mathrm{Ba}$ & $\mathrm{Cd}$ & Co & $\mathrm{Cr}$ & $\mathrm{Cu}$ & $\mathrm{Fe}$ & $\mathrm{Hg}$ & Li & $\mathrm{Mg}$ & $\mathrm{Mn}$ & $\mathrm{Ni}$ & $\mathrm{Pb}$ & Sc & $\mathrm{Sr}$ & $\mathrm{Ti}$ & V & $\mathrm{Zn}$ \\
\hline $\mathrm{Ca}(\mathrm{FC})$ & 0,26 & $0,80+$ & $0,63 \neq$ & $0,65 \neq$ & 0,58 & 0,14 & $-0,36$ & $-0,33$ & $0,67 \neq$ & 0,58 & $-0,12$ & 0,59 & 0,39 & 0,55 & 0,62 & 0,60 & 0,19 & $0,71 \neq$ & 0,49 & $-0,38$ & 0,46 & 0,58 & $-0,27$ \\
\hline $\mathrm{Mg}(\mathrm{FC})$ & 0,28 & $0,79+$ & 0,61 & 0,52 & 0,51 & 0,13 & $-0,32$ & $-0,32$ & $0,64 \neq$ & 0,53 & $-0,10$ & 0,55 & 0,31 & 0,55 & 0,61 & 0,60 & 0,27 & $0,68 \neq$ & 0,41 & $-0,35$ & 0,32 & 0,53 & $-0,19$ \\
\hline $\mathrm{Sr}(\mathrm{FC})$ & 0,26 & $0,80+$ & $0,68 \neq$ & $0,67 \neq$ & 0,58 & 0,13 & $-0,36$ & $-0,32$ & $0,67 \neq$ & 0,59 & $-0,16$ & 0,61 & 0,41 & 0,56 & 0,62 & 0,61 & 0,20 & $0,74 \neq$ & 0,50 & $-0,40$ & 0,48 & 0,59 & $-0,25$ \\
\hline $\mathrm{Fe}(\mathrm{FC})$ & 0,22 & 0,54 & $0,68 \neq$ & 0,28 & 0,51 & 0,26 & $-0,32$ & $-0,34$ & 0,58 & 0,49 & $-0,48$ & 0,56 & 0,37 & 0,58 & 0,49 & $0,64 \mp$ & 0,20 & $0,64 \neq$ & 0,44 & $-0,38$ & 0,45 & 0,44 & $-0,25$ \\
\hline $\mathrm{Ba}(\mathrm{FC})$ & 0,43 & 0,19 & 0,38 & $-0,17$ & 0,43 & 0,52 & $-0,20$ & $-0,29$ & 0,38 & 0,41 & $-0,29$ & 0,46 & 0,03 & 0,41 & 0,51 & 0,56 & 0,24 & 0,43 & 0,38 & $-0,26$ & 0,33 & 0,39 & $-0,13$ \\
\hline $\mathrm{Zn}(\mathrm{FC})$ & $-0,21$ & 0,18 & $-0,07$ & $0,64 \neq$ & 0,49 & 0,25 & $-0,36$ & 0,17 & 0,50 & $0,67 \neq$ & 0,04 & 0,54 & 0,59 & 0,57 & 0,45 & 0,55 & 0,52 & 0,52 & 0,43 & $-0,39$ & 0,34 & 0,55 & 0,15 \\
\hline $\mathrm{Al}(\mathrm{FC})$ & 0,47 & 0,48 & 0,60 & 0,23 & 0,37 & $-0,06$ & 0,05 & $-0,19$ & 0,51 & 0,39 & $-0,36$ & 0,47 & 0,19 & 0,55 & 0,45 & 0,63 & 0,20 & 0,63 & 0,21 & $-0,24$ & 0,17 & 0,36 & 0,08 \\
\hline $\mathrm{Ca}(\mathrm{F})$ & $-0,35$ & 0,01 & $-0,11$ & 0,38 & 0,41 & 0,37 & $-0,51$ & 0,33 & 0,43 & 0,57 & 0,47 & 0,44 & 0,48 & 0,51 & 0,52 & 0,30 & $0,63 \neq$ & 0,39 & 0,41 & $-0,58$ & 0,19 & 0,58 & 0,11 \\
\hline $\mathrm{Mg}(\mathrm{F})$ & $-0,21$ & $-0,39$ & $-0,71$ & $-0,14$ & $-0,61$ & $-0,46$ & 0,51 & 0,31 & $-0,50$ & $-0,40$ & 0,53 & $-0,57$ & $-0,51$ & $-0,45$ & $-0,44$ & $-0,52$ & 0,07 & $-0,50$ & $-0,66 \neq$ & 0,52 & $-0,75 \neq$ & $-0,47$ & $0,72 \neq$ \\
\hline $\mathrm{Sr}(\mathrm{F})$ & $-0,32$ & 0,01 & $-0,11$ & 0,36 & 0,43 & 0,39 & $-0,50$ & 0,27 & 0,45 & 0,59 & 0,44 & 0,46 & 0,46 & 0,53 & 0,55 & 0,31 & 0,61 & 0,40 & 0,44 & $-0,57$ & 0,21 & 0,60 & 0,09 \\
\hline $\mathrm{Fe}(\mathrm{F})$ & 0,14 & 0,30 & $-0,32$ & 0,12 & $-0,44$ & $-0,66 \neq$ & 0,49 & 0,00 & $-0,27$ & $-0,34$ & 0,30 & $-0,44$ & $-0,38$ & $-0,35$ & $-0,34$ & $-0,24$ & $-0,09$ & $-0,29$ & $-0,58$ & 0,57 & $-0,69 \neq$ & $-0,42$ & 0,38 \\
\hline $\mathrm{Ba}(\mathrm{F})$ & 0,11 & $-0,18$ & $-0,40$ & 0,23 & 0,19 & 0,08 & 0,09 & 0,07 & 0,03 & 0,27 & $-0,06$ & 0,17 & 0,13 & 0,07 & 0,07 & 0,19 & 0,04 & 0,05 & 0,14 & 0,09 & 0,16 & 0,16 & 0,15 \\
\hline $\mathrm{Zn}(\mathrm{F})$ & $-0,46$ & $-0,03$ & $-0,29$ & $-0,45$ & $-0,17$ & $-0,04$ & 0,00 & $-0,38$ & $-0,04$ & $-0,28$ & $-0,26$ & $-0,20$ & $-0,11$ & $-0,06$ & $-0,26$ & $-0,26$ & $-0,34$ & $-0,40$ & $-0,11$ & 0,09 & $-0,17$ & $-0,35$ & $-0,40$ \\
\hline Al (F) & 0,21 & 0,13 & $-0,11$ & 0,05 & 0,20 & 0,09 & 0,04 & $-0,20$ & 0,28 & 0,35 & 0,21 & 0,24 & $-0,16$ & 0,30 & 0,41 & 0,21 & 0,28 & 0,24 & 0,07 & $-0,06$ & $-0,12$ & 0,29 & 0,25 \\
\hline
\end{tabular}

Obs. +Correlação altamente significativa para valores de $p<0,01$. ¥Correlação significativa para valores $p<0,05$. (FC) - Elemento-traço carapaça corada. (F) - Elemento-traço carapaça não corada 
Matriz 6.3.2.2B - Matriz de correlação exibindo os coeficientes de Pearson para os dados de elementos-traços das carapaças de foraminíferos do emissário do TEBAR.

\begin{tabular}{|c|c|c|c|c|c|c|c|c|c|c|c|c|c|c|}
\hline & $\mathrm{Ca}(\mathrm{FC})$ & $\mathrm{Mg}(\mathrm{FC})$ & $\mathrm{Sr}(\mathrm{FC})$ & $\mathrm{Fe}(\mathrm{FC})$ & $\mathrm{Ba}(\mathrm{FC})$ & $\mathrm{Zn}(\mathrm{FC})$ & $\mathrm{Al}(\mathrm{FC})$ & $\mathrm{Ca}(\mathrm{F})$ & $\mathrm{Mg}(\mathrm{F})$ & $\operatorname{Sr}(F)$ & $\mathrm{Fe}(\mathrm{F})$ & $\mathrm{Ba}(\mathrm{F})$ & $\mathrm{Zn}(\mathrm{F})$ & $\mathrm{Al}(\mathrm{F})$ \\
\hline $\mathrm{Ca}(\mathrm{FC})$ & 1 & & & & & & & & & & & & & \\
\hline $\mathrm{Mg}(\mathrm{FC})$ & $0,95+$ & 1 & & & & & & & & & & & & \\
\hline $\mathrm{Sr}(\mathrm{FC})$ & $1+$ & $0,95+$ & 1 & & & & & & & & & & & \\
\hline $\mathrm{Fe}(\mathrm{FC})$ & 0,57 & $0,70 \neq$ & 0,61 & 1 & & & & & & & & & & \\
\hline $\mathrm{Ba}(\mathrm{FC})$ & 0,38 & 0,56 & 0,39 & $0,76 \neq$ & 1 & & & & & & & & & \\
\hline $\mathrm{Zn}(\mathrm{FC})$ & 0,19 & 0,10 & 0,20 & 0,04 & $-0,11$ & 1 & & & & & & & & \\
\hline $\mathrm{Al}(\mathrm{FC})$ & 0,54 & $0,73 \neq$ & 0,59 & $0,94+$ & $0,75 \neq$ & $-0,06$ & 1 & & & & & & & \\
\hline $\mathrm{Ca}(\mathrm{F})$ & 0,03 & $-0,05$ & 0,01 & $-0,34$ & $-0,27$ & $0,68 \neq$ & $-0,50$ & 1 & & & & & & \\
\hline $\mathrm{Mg}(\mathrm{F})$ & $-0,33$ & $-0,28$ & $-0,36$ & $-0,60$ & $-0,37$ & 0,19 & $-0,39$ & 0,29 & 1 & & & & & \\
\hline $\operatorname{Sr}(F)$ & 0,06 & $-0,03$ & 0,04 & $-0,33$ & $-0,23$ & $0,69 \neq$ & $-0,49$ & $1+$ & 0,30 & 1 & & & & \\
\hline $\mathrm{Fe}(\mathrm{F})$ & 0,26 & 0,34 & 0,24 & $-0,10$ & $-0,10$ & $-0,05$ & 0,30 & $-0,17$ & 0,61 & $-0,17$ & 1 & & & \\
\hline $\mathrm{Ba}(\mathrm{F})$ & $-0,10$ & $-0,26$ & $-0,12$ & $-0,41$ & $-0,31$ & $0,74+$ & $-0,41$ & 0,48 & 0,36 & 0,51 & 0,03 & 1 & & \\
\hline $\mathrm{Zn}(\mathrm{F})$ & $-0,44$ & $-0,36$ & $-0,43$ & 0,09 & $-0,07$ & $-0,20$ & $-0,15$ & $-0,34$ & $-0,12$ & $-0,33$ & $-0,21$ & $-0,24$ & 1 & \\
\hline $\mathrm{Al}(\mathrm{F})$ & 0,36 & 0,44 & 0,33 & 0,00 & 0,32 & 0,35 & 0,13 & 0,45 & 0,53 & 0,51 & 0,46 & 0,29 & $-0,36$ & 1 \\
\hline
\end{tabular}

Obs. +Correlação altamente significativa para valores de $p<0,01$. ₹Correlação significativa para valores $p<0,05$. (FC) - Elementotraço carapaça corada. (F) - Elemento-traço carapaça não corada 


\section{DISCUSSÃO}

\subsection{DADOS FÍSICO-QUÍMICOS E MICROBIOLÓGICOS}

Tanto no emissário do Araçá quanto no do Tebar, a profundidade dos pontos amostrais, delineadas neste estudo, foram compatíveis com as profundidades evidenciadas para estas áreas por Furtado (1995) e Barcellos \& Furtado(1999, 2001).

Baseando-se nas condições pouco estratificadas de temperatura e salinidade da água, nos pontos amostrados, foi possível inferir que essas condições geraram estrutura de massa d'água com pouca variação espacial.

Os valores de oxigênio dissolvido, nas regiões mais próximas ao fundo do emissário do TEBAR, estão abaixo do limite estabelecido pelo CONAMA 357/05, i.e. $6 \mathrm{mg} \mathrm{L}^{-1}$. Portanto, a coluna d'água pode se tornar anóxica, e, conseqüentemente, afetar diretamente o ecossistema local.

No emissário do Araçá, os valores de pH apresentaram-se homogêneos e semelhantes aos de ambientes marinhos não poluídos (Gross, 1990), conforme o valor estabelecido pelas normas do CONAMA 357/05 (i.e., $\mathrm{pH}=6,5$ a 8,5).

Já para o emissário do TEBAR, os valores de $\mathrm{pH}$, nos pontos 8 e 9, ficaram abaixo do intervalo estabelecido pelo CONAMA 357/05. Estes baixos valores de $\mathrm{pH}$ podem estar relacionados à pluma de esgoto industrial proveniente do emissário do TEBAR, a qual, devido a diferença de densidade, tende a permanecer aprisionada na parte inferior da coluna d'água. Baixos valores de $\mathrm{pH}$, i.e. $\mathrm{pH}$ ácido, podem ser prejudiciais aos organismos bentônicos, bem como contribuir para a liberação de nutrientes e contaminantes para a coluna d'água.

Os dados hidroquímicos e de turbidez ${ }^{2}$ de todas as amostras, dos emissários do Araçá e TEBAR, permaneceram abaixo dos valores do limite de deteç̧ão do método analítico (i.e., $<0,1$ ou $<0,001$ ). Estes resultados, evidenciados nas águas do entorno dos emissários, provavelmente, estão relacionados à hidrodinâmica local (FUNDESPA, 1999), que dissipa e/ou dissolve a pluma de esgoto.

\footnotetext{
2 De acordo com a CETESB (2005), a turbidez ocorre devido a partículas em suspensão e/ou colóides, os quais, em elevada densidade, impedem a passagem de luz pela zona fótica, afetando diretamente a produtividade primária local.
} 
Em relação às análises microbiológicas, a ausência de bactérias patógenas, na região do emissário do Araçá, pode estar relacionada a diversos fatores, dentre eles: 1) a cloração, que ocorre antes do efluente ser disposto, cujo objetivo é a inativação de patógenos; 2) a ação das correntes; e 3) a sensibilidade dos microrganismos a alguns fatores ambientais, tais como salinidade, temperatura e, até mesmo, outros poluentes existentes no efluente (Costa \& Carreira, 2005).

Já o emissário do TEBAR exibiu pequena concentração de bactérias patógenas em quase toda coluna d’água. Contudo, estas bactérias podem ser oriundas de outras fontes externas ao emissário (e.g. drenagens próximas com presença de efluentes clandestinos da cidade de São Sebastião), uma vez que este efluente é exclusivamente petroquímico (Fortis, 2005).

Para o efeito das análises supra mencionadas, a CETESB estabelece a disposição das malhas amostrais partindo do pressuposto de homogeneidade e diminuição de concentrações, de acordo com o sentido. Isto posto, os pontos amostrais delineados para o escopo deste estudo, embora relativamente fixos no espaço, podem ter revelado amostras resgatadas em condições diferenciadas, em função do comportamento das correntezas, ao longo do tempo, do esforço de amostragem.

Deve-se ressaltar, para o emissário submarino de esgoto do Araçá, que o sistema de bombeamento é periodicamente ativado e desativado, justamente para a realização de manutenção do sistema. Como o funcionamento do emissário não é informado a CETESB pela SABESP, no momento da amostragem, pode-se inferir, também, que os valores demonstrados refletiram a inatividade do emissário submarino.

\subsection{DADOS SEDIMENTOLÓGICOS}

No presente estudo, a granulometria obtida para o Araçá demonstrou características de sedimento depositado em condições mais energéticas, uma vez que, quase todo sedimento foi classificado como areia siltosa e, em alguns pontos, contendo cascalho. Em contrapartida, a granulometria da região do emissário do TEBAR, exibiu ambiente de baixo fluxo hidrodinâmico, que favorece a deposição de sedimentos de granulometria fina. Os resultados obtidos 
corroboraram o estudo realizado por Furtado (1978). Segundo este autor, a deposição de sedimentos de granulometria variada, como grossos a finos, devese a variações hidrodinâmicas na região central do Canal de São Sebastião. Por exemplo, em locais com características bastante energéticas, há deposição preferencial de termos grossos (Ponta do Guaecá, porção sul do canal), até condições calmas, onde se depositam os finos (Cigarras, porção norte do canal).

Os menores teores de carbonato de cálcio encontrados na região do emissário do Araçá se contrapõem à variação encontrada na região (e. g. 20 a $25 \%$ ), pelo mapa de concentração de carbonato de cálcio realizado por Conti (1998). Essa diferença de variação pode ser explicada pela constante mudança na hidrodinâmica da região. Já o emissário do TEBAR exibiu maiores teores de carbonato de cálcio em relação ao Araçá. Esta diferença de concentração pode estar, possivelmente, relacionada ao maior conteúdo de biodetritos de composição carbonática na região.

As porcentagens de carbono orgânico dos pontos A8, A9 e A10, i.e. 2,14 $\%, 2,66 \%$ e 2,63 \%, respectivamente, no Araçá; e em todos os pontos do Tebar são maiores ou próximas às obtidas na região do Porto de São Sebastião $(1,66$ \%; Barcellos e Furtado, 1999) e nos emissários da Baía da Guanabara (3,05 \%; Rebello et al., 1988) e da Baía de Santos (2 \%; Teodoro, 2006), consideradas regiões impactadas.

A quantidade de carbono orgânico no fundo dos mares depende das características sedimentológicas, da produtividade da coluna d'água, da decomposição microbiana e das condições oceanográficas locais (Barcellos, 2005).

Os valores encontrados no Araçá demonstram um enriquecimento de matéria orgânica, que, provavelmente, podem estar ligados aos fatores de baixa circulação hídrica em alguns pontos amostrais (FUNDESPA, 1999), às águas de chuva que carreiam material do continente e um incremento de matéria orgânica oriunda do aporte do emissário.

Em relação à região do TEBAR, a do Araçá apresentou menores concentrações de nitrogênio. Possivelmente, na região do Araçá, o nitrogênio está associado à matéria orgânica, já que apresentou correlação, altamente significativa, aos teores de carbono orgânico. O nitrogênio também se correlacionou, de modo significativo, ao fósforo inorgânico. Isto posto, este elemento também estar associado ao efluente do emissário, uma vez que o 
nitrogênio também é encontrado em altas concentrações nos efluentes (Faganelli, 1988).

Os sedimentos resgatados na região do Araçá evidenciaram menor concentração de enxofre em relação àqueles oriundos do TEBAR. A elevada concentração de enxofre nos pontos amostrais pode estar relacionada à pirita detrítica ou autógena. Vale ressaltar que ambas são indicativa de condições redutoras de deposição em sedimentos marinhos silicilásticos normais. Outra possível fonte diferenciada de enxofre, para sedimentos marinhos, é de natureza antrópica, como a impactação por petróleo (Berner, 1984). Para Ivanov (1981), o ciclo do enxofre nos oceanos está diretamente ligado ao ciclo de outros elementos tais como carbono, oxigênio, cálcio e diversos metais.

Na região dos emissários do Araçá e do TEBAR, o potencial de oxi-redução do sedimento, dado pela razão $\mathrm{C} / \mathrm{S}$, foi atribuída a ambiente óxico e eventos de anoxia na coluna d'água. A água pode se tornar anóxica, devido à decomposição de matéria orgânica, que diminui a concentração de oxigênio na mesma (Hedges \& Keil, 1995). Isto evidenciou, portanto, que em determinados períodos, e em alguns locais (submetidos a determinadas correntes d'água), a coluna d'água tornou-se redutora, no momento da deposição do sedimento. Este evento de anoxia, na coluna d'água, pode ser evidenciado pelos baixos valores de $\mathrm{pH}$ encontrados em algumas porções da água do TEBAR.

Em relação às porcentagens de fósforo encontradas nos sedimentos da região dos emissários submarinos do Araçá e do TEBAR, verificou-se que os valores das maiores concentrações, superaram ou estavam próximas dos de outras regiões, tais como os da Baía de Santos (0,06 \%; Teodoro, 2005) e a Baía de Guanabara (0,13 \%; Carreira, 1994), que são considerados ambientes extremamente poluídos.

Em relação ao fósforo encontrado nos sedimentos da região do emissário submarino do TEBAR, verificou-se que as concentrações, em geral, são maiores que as evidenciadas no emissário do Araçá. A diferença entre estas concentrações pode estar atrelada ao ambiente de sedimentação do TEBAR, mais propício a concentração de fósforo, e não necessariamente a um aporte maior desse elemento na região. Além disso, a região do TEBAR exibiu sensível acréscimo de fósforo orgânico em relação ao Araçá, demonstrando que, nessa região, pode ocorrer maior aporte dessa espécie, que possivelmente pode estar sendo acrescida pelo emissário submarino. Já que, segundo Hong \& Shuler 
(1988), durante a produção de petróleo submarino, pode ser injetada, na água de produção, a substância Fosfinopolicarboxilato (PPCA), inibidor de pricipitados de $\mathrm{BaSO}_{4}$ e $\mathrm{SrSO}_{4}$, rica em fósforo principalmente na forma orgânica. Essa substância agrega-se ao óleo bruto e pode-se concentrar nos fundos dos tanques. Assim, possivelmente, o efluente oriundo da drenagem de tanques pode estar enriquecido em fósforo, tanto na forma orgânica como na inorgânica.

O delineamento da dinâmica do fósforo em ambientes aquáticos tem sido considerado de extrema importância para o estabelecimento do ciclo de sedimentação em ambientes impactados (e. g., Wagener et al., 1992; Carreira \& Wagener, 1998). Em ambientes não impactados, a fonte de fósforo inorgânico solúvel é proveniente da lixiviação das rochas pela água da chuva, carreada até o mar pelos rios. O fósforo orgânico é associado ao material particulado e à matéria orgânica, carreada pelas drenagens. Este elemento é degradado, por bactérias, para se tornar inorgânico e biodisponível novamente (Kolowith et al., 2001).

Segundo Benitez-Nelson (2000) existem, essencialmente, quatro processos que foram identificados como importantes mecanismos de remoção de fósforo da coluna d'água marinha: 1) Incorporação pela matéria orgânica; 2) Sorção e precipitação de $\mathrm{P}$ com argilas e partículas de oxihidróxidos de ferro; 3 ) Precipitação de fosforitos; e 4) Processos hidrotermais.

A matéria orgânica, o material particulado e outros compostos (e.g. Fe) oriundos do efluente, juntamente com a água do mar, podem constituir um ambiente propício para a remoção do fósforo da coluna d'água e sua acumulação no sedimento, na região dos difusores do emissário, principalmente na região do TEBAR, conforme verificado por meio de sua correlação significativa com o sedimento fino e o Fe.

Como constatado pela razão C/S, em períodos de anoxia da coluna d'água, como as evidenciadas pelo baixo $\mathrm{pH}$ nas águas de alguns pontos do TEBAR, os sedimentos podem apresentar baixa capacidade de absorção de fósforo, além de poder ocorrer a ressolubilização de precipitados como $\mathrm{FePO}_{4}$, devido à redução dos íons $\mathrm{Fe}(\mathrm{III})$ a $\mathrm{Fe}(\mathrm{II})$, com a liberação dos íons fosfato para coluna d'água. Deste modo, fósforo se torna, novamente, disponível para assimilação pela biota (Carreira \& Wagener, 1998).

O fósforo é considerado um nutriente essencial e limitante em relação aos outros nutrientes, e é utilizado pelos organismos para as atividades que regulam 
o crescimento e o metabolismo energético. Dessa forma, quando as taxas de entrada desse nutriente são aumentadas e/ou modificadas no ambiente marinho, pode ocorrer redução na diversidade da cadeia alimentar, alteração na composição do fitoplâncton, e aumento na intensidade e freqüência de blooms de dinoflagelados tóxicos e marés vermelhas (Benitez-Nelson, 2000; Kolowith, et al., 2001).

Neste contexto, a análise do sedimento do Araçá revelou, ainda, maiores níveis de fósforo inorgânico em relação ao orgânico. Ao que tudo indica, o sedimento está enriquecendo com a espécie inorgânica do fósforo, por meio do aporte do efluente do emissário do Araçá. Esta afirmativa corrobora estudos anteriores, uma vez que já foram constatados elevados teores de fósforo inorgânico, em esgotamentos sanitários, não tratados, que contêm polifosfatos de produtos de limpeza e ortofosfato, e fosfatos inorgânicos condensados (Stoker, 1989; Osório \& Oliveira, 2001; Martins et al., 2007).

O sedimento do emissário do Araçá, no ponto $A 1$, onde está o trecho difusor do emissário, não apresentou valores elevados de carbono orgânico e nutrientes, em relação aos demais pontos. Este fato já havia sido previsto, à medida que o efluente, ao ser expelido pelo difusor, para a água salgada do mar, através da diferença de densidade e composição, tenha um movimento ascendente. Com a sua posterior diluição, através de reações na coluna d'água, a matéria orgânica, os nutrientes e outros contaminantes (e.g. elementos-traço) tendem a se depositar e enriquecer o sedimento mais distante do trecho difusor (Quetin \& Rouville, 1988).

Essa evidencia não foi observada no emissário do TEBAR. No geral, os níveis de carbono orgânico, nitrogênio e enxofre não demonstraram diferença significativa entre as concentrações destes compostos. Neste contexto, a composição do efluente do emissário do TEBAR, apresenta maior densidade que a água do mar, resultando em extrusão e distribuição homogênea da pluma do efluente (Fortis, 2005).

Todos os fatores supra mencionados, somados aos dados do ponto controle, evidenciaram que a região do TEBAR demonstrou condições mais favoráveis para o processo conservativo desses elementos, por apresentar condições menos energéticas, no sentido de correntes e aeração, que a do Araçá (e.g. sedimento arenoso). Mesmo diante disso, a região do Araçá mostrou-se favorável ao enriquecimento de matéria orgânica e nutrientes, principalmente na 
região mais a sudeste dos difusores, onde estão concentradas as deposições de sedimento mais fino.

$\mathrm{Na}$ região do emissário submarino do Araçá e TEBAR foi constatada matéria orgânica de origem marinha e mista. A concentração de matéria orgânica mista, que é a mistura de marinha e continental, pode ter a componente continental oriunda da matéria orgânica carreada por drenagens efetivas na porção continental, que deságuam próximo ao local, bem como a influência do porto de São Sebastião e o efluente disposto pelo emissário.

A concentração de elementos-traço, nos sedimentos na região do difusor do emissário do Araçá e do TEBAR, de um modo geral, não foi considerada tóxica para a biota marinha, quando relacionada aos valores de causa-efeito. Somente o $\mathrm{As}^{3}$, no ponto A9 para o Araçá e na maioria dos pontos do TEBAR, o Cu nos pontos T8 e T10 do TEBAR, apresentaram valores acima de TEL e/ou Limite 1. Porém esses pontos não apresentaram fator de enriquecimento significativo em relação ao ponto controle. Sendo assim, esses valores podem não estar atrelado em si, ao efluente disposto pelo emissário, mas sim ao impacto antropogênico no canal como um todo. Outra hipótese é que a origem desses elementos seja atrelada à assinatura geoquímica, na região do canal, uma vez que apresentaram correlação com outros elementos que não estavam enriquecidos significativamente em função do ponto controle. Para verificar o real impacto no meio, em relação ao As e $\mathrm{Cu}$, o sedimento deverá ser submetido a ensaios ecotoxicológicos adicionais, definido pela resolução do CONAMA no 344/2004.

No tocante ao EF (fator de enriquecimento), com a exceção dos elementos de Cd obtidos no Araçá e dos de Ba no TEBAR, de modo geral, o sedimento não demonstrou enriquecimento significativo, na maioria dos elementos maiores e traço, em relação ao ponto controle CTR. Porventura, os elementos que exibiram valores de EF enriquecidos moderadamente foram, para o Araçá, o $\mathrm{Ba}, \mathrm{Cr}, \mathrm{Cu}$, $\mathrm{Hg}$, Sr e Ti, e, para o TEBAR, foram o Cd, Cu e Sr. Isto permite inferir que, para alguns elementos, o tratamento de efluentes, efetuado no TEBAR, permanece

3 O As pode ser vinculado ao petróleo sendo oriundo dos inibidores de corrosão, utilizados nos poços de perfuração ou dos biocidas que são aplicados nos tanques de armazenamento (Wellman et al., 1999). Concentrações de As em óleo cru variam de 2,4 a 1630 ppm com média de 15 ppm (Matschullat, 2000). Apesar do óleo cru conter baixas concentrações de As, a degradação microbiana dos contaminantes do petróleo podem aumentar a dissolução dos hidróxidos e/ou óxidos de $\mathrm{Fe}$ e de $\mathrm{Mn}$ associados ao As nos sedimentos. A biodegradação do petróleo pode também produzir bicarbonato que pode absorver ou dissolver o As dos minerais. 
eficiente na remoção de alguns metais. Em relação ao Araçá, alguns metais evidenciam um processo de enriquecimento moderado e podem ter origem crustal.

Segundo Liu et al. (2003), o EF pode auxiliar na diferenciação de uma fonte antropogênica de uma origem natural dos elementos. Um valor próximo de EF a 1 indica uma origem crustal, enquanto valores próximos ou maiores que 10 podem refletir fonte não-crustal.

Grande parte dos elementos maiores e traço, analisados no sedimento da região do emissário do Araçá, foram correlacionados ao sedimento fino, à matéria orgânica e ao carbonato, sugerindo que a granulometria, o conteúdo carbonático e a matéria orgânica são fatores controladores da abundância destes elementos na região. Contudo o conteúdo de parte dos elementos maiores e traço do sedimento da região do emissário do TEBAR exibiu correlação apenas com o sedimento fino, o que permite inferir que a granulometria é a principal componente controladora da abundância desses elementos. Já a correlação significativa entre o Al e outros elementos, para ambos emissários, sugere também que estes estão associados aos aluminosilicatos.

Nas condições físico-químicas da água marinha, os elementos metálicos solubilizados, sofrem processos como a adsorção, coagulação, floculação, quelação e complexação, com o material particulado (e.g. matéria orgânica, sedimentos finos e carbonato), com posterior sedimentação deste material particulado (Soares, 1992).

No emissário do Araçá, os teores de Ti apresentaram correlação somente com os de $\mathrm{Ba}$ e o teor de areia. Essa correlação pode indicar que a origem desses dois elementos seja comum e esteja relacionada à assinatura geoquímica da região, onde esses elementos estão presente em minerais resistatos presentes na fração areia do sedimento.

Verificou-se, que o $\mathrm{Cd}^{4}$ estava correlacionado ao $\mathrm{Cu}^{5} \mathrm{e} \mathrm{Hg}^{6}$. Estes, por sua

\footnotetext{
${ }^{4} \mathrm{O}$ Cd pode ser empregado em baterias de aparelhos eletrônicos, células fotovoltaicas, em lubrificantes, na indústria plástica (como estabilizante na composição do PVC), em praguicidas e como pigmento em tintas. É um metal muito resistente à corrosão, sendo utilizado em eletrodeposição, na proteção de peças que são expostas a condições ambientais adversas, como por exemplo, água do mar (Di Toro, 1990).

${ }^{5}$ Fontes de $\mathrm{Cu}$ para o meio podem incluir efluentes, fontes industriais, tintas aplicadas para proteger os cascos das embarcações, além de ser utilizado em estações de tratamento de água como controlador de algas e fungos (CETESB, 2006).
} 
vez, foram correlacionados ao fósforo inorgânico. Nenhum destes elementos foi correlacionado aos finos, carbonato, carbono orgânico, nitrogênio e enxofre, indicando que sua distribuição está ligada a outros constituintes do sedimento. Contudo, pode existir uma componente ligada ao esgoto, disposto pelo emissário, já que o $\mathrm{Cd}$ e $\mathrm{Hg}$ do ponto $\mathrm{A} 6$ está enriquecido em relação ao ponto controle, e que a possível principal fonte do fósforo inorgânico para a região é o esgoto doméstico (e.g. Martins et al., 2007). Todavia, há uma hipótese de que exista um terceiro fator, que relaciona esses elementos ao fósforo, como por exemplo, a porção terrígena deste sedimento que contem esses elementos.

Já os teores de $\mathrm{Cr}$ apresentaram correlação negativa com os de $\mathrm{Ti}$ e com nenhum outro compartimento do sedimento. A hipótese para o $\mathrm{Cr}$ para este fato é a relação do estado de valência dominante, como a especiação do $\mathrm{Cr}$, que é controlada pelas condições físico-química do sedimento. Em condições oxidantes e $\mathrm{pH}$ alcalino predominam espécies de $\mathrm{Cr}^{6+}$ em relação ao $\mathrm{Cr}^{3+}$. Este último é caracterizado como óxidos e hidróxidos insolúveis, enquanto o hexavalente é altamente móvel e pode, facilmente, se solubilizar (Deutsch, 1997; Calder, 1988). Assim, nesta região, pela possível condição físico-química do sedimento, - $\mathrm{Cr}$ pode estar na forma hexavalente, relacionado à água intersticial do sedimento.

No ponto $A 2$, no emissário do Araçá, a razão $C / S$ revelou ambiente anóxico e esta condição pode estar facilitando a ressolubilização dos nutrientes, elementos maiores e traço para a água do mar, confirmando os menores teores dos elementos estudados para esse ponto.

Já para o emissário do TEBAR o Ba exibiu correlação altamente significativa somente com o Sr. Esse fato demonstra que sua distribuição possivelmente esteja relacionada. O Ba no ponto T3 demonstrou-se enriquecido e neste mesmo ponto o Sr encontra-se elevado em relação ao demais pontos. Nos pontos mais próximos aos difusores do emissário encontram-se concentrações maiores que os demais pontos. Uma provável explicação para essa concentração é a possível concentração de $\mathrm{Ba}$ e $\mathrm{Sr}$ no efluente disposto pelo emissário do TEBAR.

Segundo o estudo de McTeir et al. (1988), em águas de produção petrolífera submarinas, são elevadas as concentrações de íons de $\mathrm{SO}_{4}{ }^{2-}, \mathrm{Ba}^{2+} \mathrm{e}$

${ }^{6} \mathrm{O} \mathrm{Hg}$ é freqüentemente associado a efluentes domésticos e refinarias, e também é empregado em lâmpadas, pilhas, amálgamas dentárias (CETESB, 2006). 
$\mathrm{Sr}^{2+}$. Estes elementos formam precipitados de $\mathrm{BaSO}_{4}$ e $\mathrm{SrSO}_{4}$, resultando em depósitos nas paredes das tubulações e dos tanques de petróleo. Como o efluente do TEBAR é também proveniente das águas de produção, oriundas da drenagem do fundo dos tanques do terminal e dos navios, esse pode ter uma concentração desses elementos.

As águas de produção são enriquecidas em $\mathrm{Ba}$, devido o emprego do mineral barita, sob a forma moída, junto à lama de perfuração dos poços petrolíferos, em que acaba por impregnar as paredes dos poços. A barita, devido sua densidade, é utilizada para auxiliar no escoamento da lama de perfuração (bentonita) por toda a extenção do poço. Após a perfuração, no momento da extração do petróleo, a água de produção acaba por enriquencer de Ba. Já o Sr é comumente associada a barita devido sua afinidade iônica com o Ba. 


\subsection{ELEMENTOS-TRAÇO CONTIDO NAS CARAPAÇAS DE FORAMINÍFEROS}

Segundo Lea (1999), os foraminíferos, enquanto organismos vivos precipitam, ativamente, suas carapaças, afetando tanto a precipitação quanto a química da carapaça de calcita. Esta precipitação ativa é atribuída a um significativo controle biológico e/ou cinético sobre a substituição dos elementostraço.

A calcificação da carapaça é, relativamente, rápida, variável no tempo, e influenciada por fatores externos que, tomados em conjunto, contribuem para o não-equilíbrio das reações envolvidas na secreção das carapaças (Lea et al., 1995).

Os elementos-traço são incorporados diretamente do meio durante a precipitação da carapaça dos foraminíferos. Assim, a composição da carapaça destes protozoários reflete tanto a composição do meio quanto às condições físicas e biológicas no momento da precipitação (Lea, 1999).

No tocante às análises qualitativas de EDS, na região do emissário do Araçá, as concentrações de elementos associados às carapaças não coradas revelaram que estes podem estar ligados a processos diagenéticos. Neste contexto, o $\mathrm{Fe}$ e o $\mathrm{S}$ podem indicar a piritização da carapaça, atribuída à condição redox e à concentração de pirita no sedimento (Yanko et al., 1999).

Ainda na região do Araçá, outros elementos, excetuando o Ca e o O (possivelmente carbonato), como o $\mathrm{K}, \mathrm{Na}, \mathrm{Si}, \mathrm{Al}$ e $\mathrm{Cl}$, podem ser oriundos de argilo-minerais e sais agregados à carapaça. Neste sentido, a presença de elementos como o $\mathrm{Cu}$ e $\mathrm{Ba}$ pode estar atrelada a minerais adsorvidos. Essas partículas, de modo geral, estavam adsorvidas em regiões com presença de poros. Além disso, podem ser incorporadas ao fluxo de matéria, do qual o organismo participa, interferindo ou não em sua homeostase, i.e. processos metabólicos sob condições normais. Todavia, em relação à matriz da carapaça, dos espécimes desta região, não foi observada a presença de elementos-traço, apenas a composição carbonática.

Nas carapaças de foraminíferos coletadas na região do TEBAR, as análises qualitativas de EDS demonstraram uma faixa de elementos semelhantes aos indivíduos do Araçá. A matriz revelou-se, também, basicamente, carbonática e com a presença de partículas adsorvidas, possivelmente, argilo-minerais, sais e fosfatos. De modo geral, essas partículas estavam, também, adsorvidas em 
regiões com presença de poros. No âmbito dessas análises, não foram encontrados elementos-traços associados à composição carbonática da carapaça dos foraminíferos, por meio das análises de EDS.

Sob MEV e estereomicroscópio, não foram observadas deformações nas carapaças desses foraminíferos, como verificadas por Romano et al. (2008) e Frontalini et al. (2009), quando submetidos a esses elementos em concentração.

Contudo, no contexto dos estudos sobre as carapaças de A. tepida, realizados neste trabalho, embora as análises qualitativas retro citadas tenham se revelado importantes na determinação de características morfológicas dos espécimes, as análises quantitativas demonstraram uma maior capacidade de detecção, e melhores parâmetros de comparação entre as regiões dos emissários, para uma série de elementos-traço, não evidenciados em técnicas qualitativas, como o EDS.

Diante disso, no âmbito das análises quantitativas realizadas neste trabalho, metais e elementos-traço do sedimento coletado na região do Araçá apresentaram menor número de correlações com elementos-traço das carapaças dos foraminíferos, quando comparados aos coletados na região do TEBAR.

Salvo exceções, não foi observada correlação entre elementos homônimos (e.g. Fe e Fe) no sedimento e na carapaça. Neste contexto, os elementos químicos presentes no sedimento, não apresentam, necessariamente, livre acesso ao meio intracelular dos foraminíferos, e estão submetidos a uma série de mecanismos e processos metabolicamente controlados, pelo complexo de membranas e pelas reações em cascata $^{7}$ que têm lugar no hialoplasma. Por outro lado, foram constatadas correlações entre elementos heterônimos (e.g. $\mathrm{Cr}$ e $\mathrm{Mg}$; $\mathrm{Pb}$ e $\mathrm{Ca}$ ). Esta correlação pode ser evidenciada no metabolismo das células eucariontes, em que diferentes elementos químicos se controlam em reações metabólicas e/ou se ligam às moléculas de mesma importância biológica (Vincent, 1999; Hörcsik et al., 2006; Raitzsch et al., 2010).

No Araçá, o Zn das carapaças não coradas de $A$. tepida foi correlacionado ao $\mathrm{Zn}$ do sedimento. Além disso, a correlação do $\mathrm{Zn}$ das carapaças e dos sedimentos com outros elementos ( $\mathrm{Al}, \mathrm{Co}, \mathrm{Mg}, \mathrm{Mn}, \mathrm{Ni}, \mathrm{Pb}, \mathrm{Sc}, \mathrm{V}, \mathrm{Zn}$ ), revelou uma possível relação.do Zn das carapaças a processos diagenéticos.

\footnotetext{
7 Reações bioquímicas em que os produtos de uma reação são consumidos na seguinte reação (Nelson \& Cox, 2004).
} 
Neste contexto, Boyle (1981) evidenciou uma potencial desvantagem na utilização do Zn como indicador ambiental, à medida que a concentração deste elemento nas carapaças pode estar susceptível ao viés dos processos post mortem.

Para o emissário do TEBAR, o Zn das carapaças coradas apresentou correlação fósforo inorgânico do sedimento. Este resultado corrobora o Zn enquanto indicador geoquímico de nutrientes na carapaça de foraminíferos (Bruland, 1983).

Já o carbono orgânico, o nitrogênio e o fósforo inorgânico do sedimento foram correlacionados a alguns elementos-traço das carapaças coradas do TEBAR (e.g. Ca, Mg, Sr, Fe). Esta correlação pode revelar a influência da matéria orgânica e dos nutrientes sob a forma como os elementos-traço são incorporados nas carapaças.

No Araçá, enquanto as concentrações de $\mathrm{Mg}$ se revelaram mais elevadas para os espécimes corados que para os não corados, o Sr não apresentou diferença significativa em seus teores, entre carapaças coradas e não coradas. Além disso, houve correlação altamente significativa entre os teores de $\mathrm{Ca}, \mathrm{Mg}$ e Sr, nas carapaças coradas.

Neste contexto, o aumento das razões de calcificação e a incorporação de Sr na calcita foram atribuídos a fatores físico-químicos, tais como, a elevação do $\mathrm{pH}$, à temperatura, à pressão e à saturação da calcita no meio (Lea, 1999).

Todavia, ao que tudo indica, a incorporação de $\mathrm{Mg}$ pode estar atrelada, indiretamente, à de $\mathrm{Sr}$, e é mediada por um complexo e indireto atalho envolvido nas taxas de calcificação (Carpenter \& Lohmann, 1992).

A análise das amostras resgatadas no Araçá revelou que os teores de $\mathrm{Mg}$ evidenciados nas carapaças de espécimes corados $A$. tepida também foram positivamente correlacionados às concentrações de $\mathrm{Cr}$ nos sedimentos. Já no Tebar, não houve estabelecimento dessa correlação. Estes resultados podem ser atribuídos a propriedades toxicológicas das espécies de $\mathrm{Cr}$ e ecológicas de $A$. tepida.

Em sua forma trivalente, o $\mathrm{Cr}$ têm se revelado como fator limitante no metabolismo dos seres vivos ${ }^{8}$. Contudo, elevados teores de $\mathrm{Cr}$ podem levar a uma diminuição de $\mathrm{Mg}$ no interior das células eucariontes. A diminuição nas

\footnotetext{
${ }^{8}$ P. ex.: síntese de glicose, lipídeos e proteínas.
} 
concentrações de Fe e Mg, associada a elevados teores de $\mathrm{Cr}$, nas células de microrganismos, está atrelada a evidenciação de altos níveis de Ca intracelular e em sistemas exoesqueléticos (Hörcsik et al., 2006; Leghouchi et al., 2009). Adicionalmente, experimentos em cultura demonstraram que a incorporação de Mg em carapaças de $A$. tepida diminuem com o aumento da concentração de Ca (Raitzsch et al., 2010).

Diante disso, a correlação entre os teores de $\mathrm{Mg}$, nas carapaças dos foraminíferos corados, e de $\mathrm{Cr}$, no sedimento, provenientes das amostras coletadas no Araçá, pode ser relacionada à condição ecológica oportunística de $A$. tepida. Este táxon oportunista é tolerante (e pode estar adaptado) a um contexto de condições tóxicas, delineado pela presença de $\operatorname{Cr}(\mathrm{VI})^{9}$. Diante dessas concentrações de $\mathrm{Cr}$, $A$. tepida pode, ainda, estar equilibrando os altos níveis de $\mathrm{Cr}$ no meio pela elevação dos teores de $\mathrm{Mg}$ celular. De acordo com a literatura, $\mathrm{Cr}(\mathrm{VI})$ e $\mathrm{Cr}$ (III) induzem alterações metabólicas relacionadas ao citoesqueleto, ao movimento celular e às fases de crescimento em protozoários, tais como, Euglena gracilis (Cervantes et al., 2001).

Em contrapartida, no Tebar, os teores não correlacionados de $\mathrm{Mg}$, nas carapaças dos foraminíferos corados, e de $\mathrm{Cr}$, nos sedimentos, podem ser atribuídos a forma trivalente não tóxica e, evidentemente, ligada ao sedimento, do $\mathrm{Cr}$ (Calder, 1988).

Do mesmo modo que o $\mathrm{Cr}$, o $\mathrm{Pb}$ pode alterar, de modo significativo, a homeostase celular do Ca (e.g. transporte e regulação). Conforme supra citado, Mg e Sr também estão intrinsecamente correlacionados ao metabolismo do Ca. No âmbito das análises das amostras coletadas no Tebar, houve correlação positiva de $\mathrm{Pb}$, nos sedimentos, e $\mathrm{Ca}, \mathrm{Mg}, \mathrm{Sr}$ e $\mathrm{Fe}$, nas carapaças dos foraminíferos corados. A correlação entre estes elementos, observada para as amostras do Tebar, pode refletir a interferência do $\mathrm{Pb}$ nas reações intracelulares dependentes de ou ligadas ao $\mathrm{Ca}$, já corroboradas pela literatura. Estas alterações metabólicas podem incorrer em processos biológicos nocivos aos organismos (Yamaguchi \& Yamomoto, 1974; Kato et al., 1977; Peng et al., 1979; Pounds et al., 1982).).

\footnotetext{
${ }^{9}$ As propriedades tóxicas do $\mathrm{Cr}(\mathrm{VI})$ podem ser resultantes da livre difusão através das membranas celulares e do seu forte potencial oxidativo. O impacto toxicológico do $\mathrm{Cr}(\mathrm{VI})$ é produto de sua ação enquanto oxidante, tanto quanto da formação de radicais livres durante a redução do $\mathrm{Cr}(\mathrm{VI})$ para $\mathrm{Cr}(\mathrm{III})$ em meio intracelular (Nieboer \& Jusys 1988; Kornhauser et al. 2002).
} 
Enquanto nas amostras oriundas do Araçá, as concentrações de $\mathrm{Pb}$ perfizeram um total de $11 \mathrm{ppm}$, no Tebar, os valores evidenciados foram de 20 ppm. Alguns estudos demonstraram que mesmo a exposição a baixas concentrações de $\mathrm{Pb}(2,07 \mathrm{ppm})$ pode alterar a homeostase de Ca em sistemas intactos de cultura celular (Pounds et al., 1982). Neste sentido, os níveis de $\mathrm{Mg}^{10}$, também se revelaram menores (i.e. 1,8 ppb) no Tebar, em comparação aos encontrados no Araçá (i.e. 6,8 ppb).

As considerações acerca das correlações entre metais e/ou elementostraço de sedimentos versus carapaças foram ao encontro das correlações estabelecidas entre os elementos das carapaças. Neste contexto, tanto na região do Araçá quanto na do TEBAR houve correlação entre $\mathrm{Ca}, \mathrm{Mg}, \mathrm{Fe}, \mathrm{Sr}, \mathrm{Ba}$ e $\mathrm{Al}$, nas carapaças coradas de foraminíferos.

Em ambos os emissários, as carapaças dos foraminíferos vivos demonstraram maior número de correlações com o sedimento. Portanto, no âmbito deste estudo, as carapaças dos foraminíferos vivos se revelaram melhores indicadores biogeoquímicos que as carapaças dos mortos, uma vez que estes estão susceptíveis ao viés dos processos diagenéticos.

10 Conforme anteriormente discutido, o $\mathrm{Mg}$ está relacionado ao metabolismo do Ca, apresentando concentrações inversamente proporcionais ao $\mathrm{Ca}$ em meio celular. 


\section{CONCLUSÃO}

Os resultados das análises físico-químicas e microbiológica da água, próxima aos difusores dos dois emissários, não foram suficientes para um monitoramento eficaz da qualidade do meio, uma vez que, a CETESB estabelece a disposição das malhas amostrais partindo do pressuposto de homogeneidade e diminuição de concentrações de constituintes do efluente conforme o sentido. Assim, embora relativamente fixos no espaço, os pontos amostrais podem ter revelado coletas em condições diferenciadas, em função do comportamento das correntezas, ao longo do tempo de amostragem.

As concentrações de carbono orgânico, nitrogênio, enxofre e fósforo somados aos dados do ponto controle, revelaram que a região do entorno do difusor do emissário do Araçá mostrou-se propícia ao enriquecimento de nutrientes e matéria orgânica, principalmente na região mais a sudeste dos difusores, onde foram verificadas condições potenciais à deposição. Por outro lado, a região próxima ao difusor do emissário do TEBAR demonstrou condições mais favoráveis para o processo conservativo desses elementos, uma vez que apresentou ambiente deposicional de menor energia que a do Araçá.

A origem da matéria ogânica na região do emissário submarino do Araçá e do TEBAR foi considerada marinha e mista. A concentração de matéria orgânica mista pode ser oriunda da matéria orgânica carreada por drenagens efetivas na porção continental, que deságuam próximo ao local, bem como a influência do porto de São Sebastião e o efluente disposto pelo emissário.

O potencial de oxi-redução do sedimento demonstrou, de modo geral, que os ambientes de sedimentação apresentaram características óxicas. Contudo, em alguns locais, o sedimento foi depositado sob influência de anoxia na coluna d'água. A água pode estar se tornando anóxica, em determinados períodos, devido, possivelmente, à redução da concentração de oxigênio na água.

$\mathrm{Na}$ maioria dos pontos, a concentração de elementos-traço, nos sedimentos, na região do difusor do emissário do Araçá e do TEBAR, com execeção do arsênio no Araçá e no TEBAR, e do cobre no TEBAR, em relação aos valores de causa-efeito, não foi considerada tóxica, para a biota marinha.

Entretanto, o As e o $\mathrm{Cu}$ não apresentaram fator de enriquecimento significativo, em relação ao ponto controle, e sua concentração pode estar ligada a fontes externas aos emissários (e.g. ao impacto antropogênico e/ou assinatura 
geoquímica no canal). Diante desses resultados, são necessários ensaios ecotoxicológicos complementares, em relação ao As e ao Cu no sedimento, para avaliar os seus impactos no meio.

No emissário do TEBAR, o Ba e o Sr apresentaram um enriquecimento significativo, demonstrando que a área próxima ao difusor estava enriquecida nesses elementos. Isto posto, é possível inferir que as essas concentrações podem ser oriundas do efluente disposto pelo emissário do TEBAR.

Em relação aos foraminíferos, as carapaças de $A$. tepida coradas, em ambos os emissários, apresentaram maior número de correlações significativas com o sedimento. Portanto, no âmbito deste estudo, as carapaças de foraminíferos mortos se revelaram susceptíveis ao viés dos processos diagenéticos, ao passo que as carapaças dos foraminíferos vivos se revelaram melhores indicadores biogeoquímicos que as dos mortos.

Neste contexto, houve correlação entre $\mathrm{Ca}, \mathrm{Mg}$, $\mathrm{Fe}, \mathrm{Sr}, \mathrm{Ba}$ e $\mathrm{Al}$, nas carapaças coradas de foraminíferos versus metais e/ou elementos-traço no sedimento. Isto corrobora a influência da composição do sedimento nas reações intracelulares dos foraminíferos, refletidas na construção do exoesqueleto.

Diante do exposto, os resultados deste estudo trouxeram luz a novas questões que permitiram inferir que somente a auto-depuração da água do mar, em ambas as regiões, e a estação de tratamento de efluentes, no TEBAR, não se revelou eficiente na diluição e/ou remoção do conteúdo de nutrientes, matéria orgânica e alguns elementos-traço.

Além disso, este trabalho, por meio da análise das carapaças de $A$. tepida, demonstrou que a utilização de foraminíferos como bioindicadores não deve estar circunscrita ao escopo de variáveis isoladas. O entendimento de funções intrínsecas e específicas de táxons indicadores biogeoquímicos (e.g. ecologia de spp. oportunistas e biologia celular) reveste-se de importância para o delineamento de contextos ecossistêmicos (e.g. composição de populações e comunidades) e sedimentológicos (e.g. elementos-traço evidenciados nas carapaças). 
VIII ANEXOS 


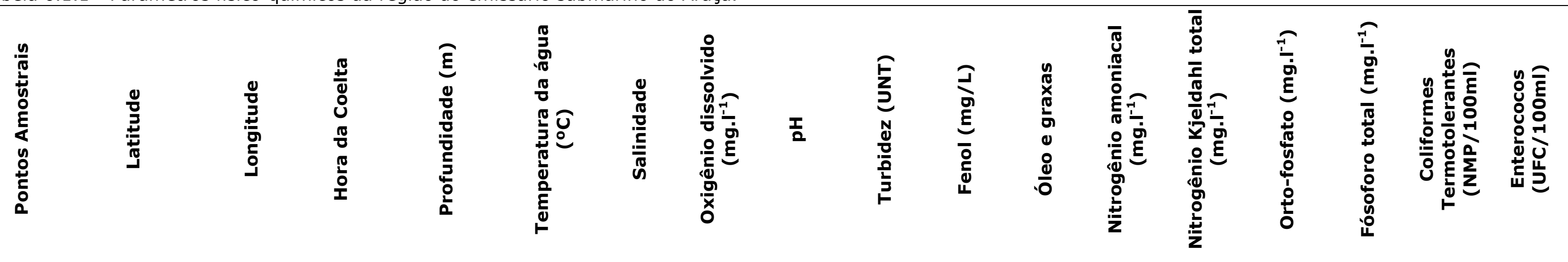

\begin{tabular}{|c|c|c|c|c|c|c|c|c|c|c|c|c|c|c|c|c|c|}
\hline CONAMA & $20 / 86$ e 357 & 105 & & & & $\geq 30$ & 6 & 6,5 a 8,5 & & & 0 & 0,4 & & & 0,062 & 1000 & 100 \\
\hline \multirow[t]{3}{*}{ A1 } & 23,81927777 & 45,403992 & $10: 10$ & Superfície (0) & $*$ & $*$ & $*$ & 7,98 & 3,8 & $<0,003$ & $<10$ & $<0,01$ & $<0,1$ & $<0,01$ & $<0,01$ & $<1$ & $<1$ \\
\hline & & & $10: 15$ & Meio (3) & * & * & * & 8,07 & 1,8 & $<0,003$ & & $<0,01$ & $<0,1$ & $<0,01$ & $<0,01$ & $<1$ & $<1$ \\
\hline & & & $10: 20$ & Fundo (6) & * & * & * & 8,07 & 1,8 & $<0,003$ & & $<0,01$ & $<0,1$ & $<0,01$ & $<0,01$ & $<1$ & $<1$ \\
\hline \multirow[t]{3}{*}{ A2 } & 23,81987292 & 45,404367 & $11: 13$ & Superfície (0) & * & * & * & 8,10 & 0,62 & $*$ & $<10$ & $<0,01$ & $<0,1$ & $<0,01$ & $<0,01$ & $<1$ & $<1$ \\
\hline & & & $11: 15$ & Meio (5) & * & * & * & 8,11 & 0,76 & * & & $<0,01$ & $<0,1$ & $<0,01$ & $<0,01$ & $<1$ & $<1$ \\
\hline & & & $11: 20$ & Fundo (10) & * & * & * & 8,11 & 1,6 & * & & $<0,01$ & $<0,1$ & $<0,01$ & $<0,01$ & $<1$ & $<1$ \\
\hline \multirow[t]{3}{*}{ A3 } & 23,82030873 & 45,403504 & $11: 55$ & Superfície (0) & * & * & * & 8,11 & 0,93 & * & $<10$ & $<0,01$ & $<0,1$ & $<0,01$ & $<0,01$ & $<1$ & $<1$ \\
\hline & & & $11: 58$ & Meio (5) & * & * & * & 8,14 & 1,2 & * & & $<0,01$ & $<0,1$ & $<0,01$ & $<0,01$ & $<1$ & $<1$ \\
\hline & & & $12: 00$ & Fundo (10) & * & * & * & 8,16 & 1 & $*$ & & $<0,01$ & $<0,1$ & $<0,01$ & $<0,01$ & $<1$ & $<1$ \\
\hline \multirow[t]{3}{*}{ A4 } & 23,81924439 & 45,403118 & $12: 25$ & Superfície (0) & * & * & * & 8,17 & 1,1 & $<0,003$ & $<10$ & $<0,01$ & $<0,1$ & $<0,01$ & $<0,01$ & $<1$ & $<1$ \\
\hline & & & $12: 28$ & Meio (4) & * & * & * & 8,11 & 1,2 & $<0,003$ & & $<0,01$ & $<0,1$ & $<0,01$ & $<0,01$ & $<1$ & $<1$ \\
\hline & & & $12: 30$ & Fundo (8) & * & * & * & 8,11 & 0,95 & $<0,003$ & & $<0,01$ & $<0,1$ & $<0,01$ & $<0,01$ & $<1$ & $<1$ \\
\hline \multirow[t]{3}{*}{ A5 } & 23,81853782 & 45,403724 & $12: 59$ & Superfície (0) & * & * & * & 8,17 & 3,4 & $<0,003$ & $<10$ & $<0,01$ & $<0,1$ & $<0,01$ & $<0,01$ & $<1$ & $<1$ \\
\hline & & & $12: 55$ & Meio (1) & * & * & * & 8,16 & 2,2 & $<0,003$ & & $<0,01$ & $<0,1$ & $<0,01$ & $<0,01$ & $<1$ & $<1$ \\
\hline & & & $13: 02$ & Fundo (3) & * & * & * & 8,12 & 1,6 & $<0,003$ & & $<0,01$ & $<0,1$ & $<0,01$ & $<0,01$ & $<1$ & $<1$ \\
\hline \multirow[t]{3}{*}{ A6 } & 23,82010737 & 45,404515 & $13: 30$ & Superfície (0) & 30 & * & * & 8,11 & 1,2 & $*$ & $<10$ & $<0,01$ & $<0,1$ & $<0,01$ & $<0,01$ & $<1$ & $<1$ \\
\hline & & & $13: 35$ & Meio (4) & 28,9 & * & * & 8,10 & 0,62 & * & & $<0,01$ & $<0,1$ & $<0,01$ & $<0,01$ & $<1$ & $<1$ \\
\hline & & & $13: 39$ & Fundo (7) & 28,8 & * & * & 8,12 & 1 & * & & $<0,01$ & $<0,1$ & $<0,01$ & $<0,01$ & $<1$ & $<1$ \\
\hline \multirow[t]{3}{*}{ A7 } & 23,8205483 & 45,405144 & $14: 15$ & Superfície (0) & 29 & * & * & 8,10 & 2,3 & $<0,003$ & $<10$ & $<0,01$ & $<0,1$ & $<0,01$ & $<0,01$ & $<1$ & $<1$ \\
\hline & & & $14: 25$ & Meio (5) & 29,1 & * & * & 8,11 & 1,3 & $<0,003$ & & $<0,01$ & $<0,1$ & $<0,01$ & $<0,01$ & $<1$ & $<1$ \\
\hline & & & $14: 18$ & Fundo (11) & 28,4 & * & * & 8,11 & 1,1 & $*$ & & $<0,01$ & $<0,1$ & $<0,01$ & $<0,01$ & $<1$ & $<1$ \\
\hline \multirow[t]{3}{*}{ A8 } & 23,82078667 & 45,4038 & $14: 45$ & Superfície (0) & 29 & * & * & 8,11 & 1,5 & * & $<10$ & $<0,01$ & $<0,1$ & $<0,01$ & $<0,01$ & $<1$ & $<1$ \\
\hline & & & $14: 50$ & Meio (8) & 29 & * & * & 8,11 & 0,65 & * & & $<0,01$ & $<0,1$ & $<0,01$ & $<0,01$ & $<1$ & $<1$ \\
\hline & & & $14: 47$ & Fundo (13) & 28,2 & * & * & 8,14 & 1,3 & $*$ & & $<0,01$ & $<0,1$ & $<0,01$ & $<0,01$ & $<1$ & $<1$ \\
\hline \multirow[t]{3}{*}{ A9 } & 23,82001336 & 45,402472 & $15: 36$ & Superfície (0) & 29,4 & * & * & 8,14 & 0,96 & $<0,003$ & $<10$ & $<0,01$ & $<0,1$ & $<0,01$ & $<0,01$ & $<1$ & $<1$ \\
\hline & & & $15: 38$ & Meio (8) & 28,6 & * & * & 8,12 & 0,86 & $<0,003$ & & $<0,01$ & $<0,1$ & $<0,01$ & $<0,01$ & $<1$ & $<1$ \\
\hline & & & $15: 32$ & Fundo (15) & 26,4 & * & * & 8,08 & 0,88 & $<0,003$ & & $<0,01$ & $<0,1$ & $<0,01$ & $<0,01$ & $<1$ & $<1$ \\
\hline \multirow[t]{3}{*}{ A10 } & 23,81874874 & 45,402508 & $15: 58$ & Superfície (0) & 29,1 & * & * & 8,14 & 1,2 & $*$ & $<10$ & $<0,01$ & $<0,1$ & $<0,01$ & $<0,01$ & $<1$ & $<1$ \\
\hline & & & $16: 03$ & Meio (6) & 28,9 & * & * & 8,15 & 1,1 & * & & $<0,01$ & $<0,1$ & $<0,01$ & $<0,01$ & $<1$ & $<1$ \\
\hline & & & $16: 00$ & Fundo (12) & 26,6 & * & * & 8,10 & 2,1 & * & & $<0,01$ & $<0,1$ & $<0,01$ & $<0,01$ & $<1$ & $<1$ \\
\hline
\end{tabular}

Obs.: Dados fornecidos pela Companhia Ambiental do Estado de São Paulo (CETESB).* informação ausente 
Tabela 6.1 2.2.2A - Dados de metais e elementos-traços contidos no sedimento da região do emissário do Araçá.

\begin{tabular}{|c|c|c|c|c|c|c|c|c|c|c|c|c|c|c|c|c|c|c|c|}
\hline $\begin{array}{l}0 \\
\frac{\pi}{0} \\
0 \\
0 \\
0 \\
0 \\
0 \\
0 \\
0 \\
0\end{array}$ & 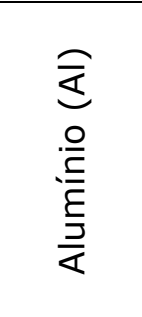 & 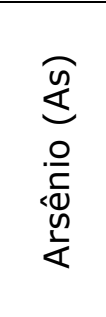 & 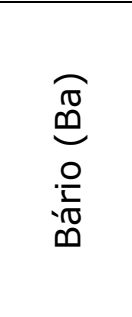 & 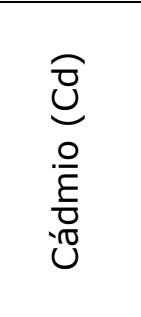 & 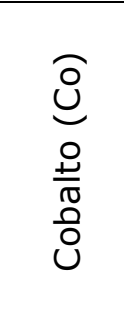 & 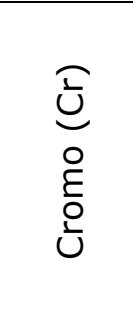 & $\begin{array}{l}\widehat{3} \\
0 \\
0 \\
0 \\
0 \\
0\end{array}$ & 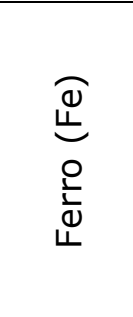 & 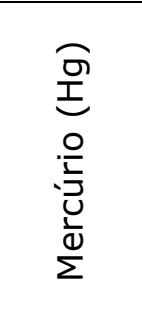 & 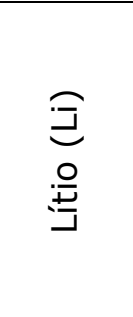 & 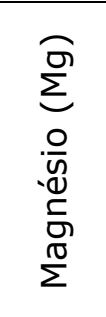 & 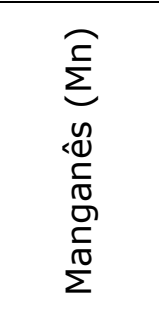 & $\begin{array}{l}\widehat{\bar{z}} \\
\bar{\Phi} \\
\frac{\bar{v}}{z}\end{array}$ & 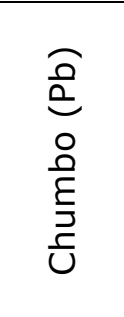 & 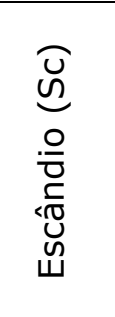 & 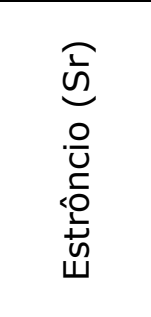 & 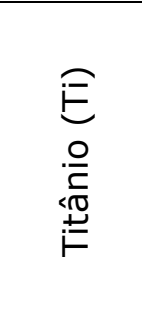 & 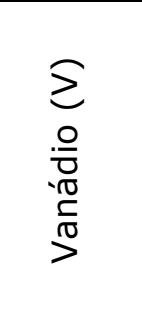 & 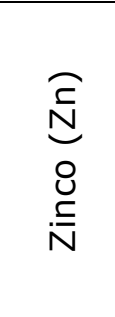 \\
\hline Unidade & $\%$ & PPM & PPM & PPM & PPM & PPM & PPM & $\%$ & PPM & PPM & $\%$ & PPM & PPM & PPM & PPM & PPM & $\%$ & PPM & PPM \\
\hline Limite de Detecção & 0,01 & 0,1 & 0,5 & 0,01 & 0,1 & 0,5 & 0,01 & 0,01 & 0,005 & 0,1 & 0,01 & 1 & 0,1 & 0,01 & 0,1 & 0,5 & 0,001 & 2 & 0,1 \\
\hline Nível 1 (CONAMA, 2004) & & 8,2 & & 1,2 & & 81 & 34 & & 0,15 & & & & 20,9 & 46,7 & & & & & 150 \\
\hline Nível 2 (CONAMA, 2004) & & 70 & & 9,6 & & 370 & 270 & & 0,71 & & & & 51,6 & 218 & & & & & 410 \\
\hline TEL (CCME, 2002) & & 7,24 & & 0,7 & & 52,3 & 18,7 & & 0,13 & & & & 15,9 & 30,2 & & & & & 124 \\
\hline PEL (CCME, 2002) & & 41,6 & & 4,2 & & 160 & 108 & & 0,7 & & & & 42,8 & 112 & & & & & 271 \\
\hline $\mathrm{A} 1$ & 1,05 & 4,7 & 34,2 & $<0,01$ & 3,8 & 17,5 & 4,92 & 1,46 & 0,013 & 15,5 & 0,52 & 198 & 6,3 & 7,97 & 2,8 & 54,8 & 0,054 & 19 & 34,2 \\
\hline A2 & 0,70 & 2,4 & 21,1 & $<0,01$ & 2,2 & 48,2 & 7,41 & 0,84 & 13 & 9,8 & 0,28 & 131 & 4,9 & 6,41 & 1,6 & 70,1 & & 13 & 22,8 \\
\hline A3 & 1,21 & 5,1 & 29,9 & 0,03 & 4,2 & 20,3 & 11,97 & 1,55 & 0,027 & 18,3 & 0,59 & 249 & 8,0 & 10,64 & 3,1 & 73,6 & 0,053 & 22 & 40,3 \\
\hline A4 & 1,28 & 5,4 & 37,1 & 0,02 & 4,8 & 23,1 & 6,81 & 1,74 & 0,018 & 19,7 & 0,62 & 251 & 8,2 & 10,39 & 3,5 & 53,2 & & 23 & 40,7 \\
\hline A5 & 1,05 & 5,2 & 53,3 & $<0,01$ & 4,1 & 18,7 & 4,98 & 1,55 & 0,018 & 15,8 & 0,55 & 208 & 7,1 & 8,26 & 2,7 & 38,8 & 0,056 & 20 & 34,3 \\
\hline A6 & 0,97 & 2,6 & 34,7 & 0,05 & 3,2 & 16,4 & 17,13 & 1,21 & 0,083 & 13,4 & 0,43 & 142 & 7,4 & 10,61 & 2,6 & 29,0 & & 19 & 47,9 \\
\hline A7 & 0,94 & 3,9 & 29,3 & $<0,01$ & 3,4 & 15,6 & 5,42 & 1,32 & 0,025 & 15,0 & 0,49 & 184 & 6,9 & 8,51 & 2,6 & 115,6 & 0,053 & 18 & 31,0 \\
\hline A8 & 1,61 & 6,2 & 29,2 & 0,01 & 4,9 & 26,0 & 6,72 & 2,04 & 0,022 & 23,0 & 0,73 & 326 & 10,3 & 13,12 & 3,5 & 327,8 & & 32 & 39,5 \\
\hline A9 & 1,86 & 7,3 & 26,7 & 0,02 & 5,6 & 27,5 & 7,88 & 2,18 & 0,026 & 25,6 & 0,90 & 365 & 11,6 & 15,41 & 4,0 & 310,1 & 0,045 & 33 & 42,9 \\
\hline A10 & 2,01 & 7,2 & 31,7 & 0,02 & 6,4 & 30,7 & 9,55 & 2,36 & 0,029 & 29,4 & 0,94 & 405 & 13,1 & 18,84 & 4,7 & 122,9 & 0,053 & 35 & 52,6 \\
\hline Mín. & 0,7 & 2,4 & & & 2 & & & 0 , & & 9,8 & & & 4,9 & & 1,6 & & & 13,0 & 22,8 \\
\hline Máx. & & 7,30 & & 0,0 & & & 17,13 & & 0,0 & 29,40 & 0,94 & & 13,10 & 18,84 & 4,70 & & & & 52,60 \\
\hline $\bar{x}$ & 1,27 & 5,00 & 32,72 & 0,03 & 4,26 & 24,40 & 8,28 & 1,63 & 0,03 & 18,55 & 0,61 & 245,90 & 8,38 & 11,02 & 3,11 & 119,59 & 0,05 & 23,40 & 38,62 \\
\hline$s$ & 0,43 & 1,69 & 8,52 & 0,01 & 1,22 & 9,77 & 3,79 & 0,47 & 0,02 & 5,97 & 0,20 & 92,80 & 2,53 & 3,80 & 0,86 & 109,33 & 0,01 & 7,38 & 8,53 \\
\hline CTR & 2,26 & 7,7 & 30,4 & 0,01 & 7,1 & 34,6 & 9,25 & 2,51 & 0,021 & 32,1 & 0,92 & 398 & 13,9 & 17,99 & 4,9 & 108,1 & 0,051 & 37 & 52,4 \\
\hline Padrão STD DS7 E & 0,959 & 3,2 & & & 9,7 & & & 9 & & 29,3 & & 627 & 56 & 70,6 & 2,5 & 68 & & 84 & 411 \\
\hline Padrão STD DS7 Certificado & 1,04 & 53,2 & 391,8 & 6,10 & 9,3 & 219,0 & 110,30 & 2,40 & 0,191 & 27,5 & 1,04 & 606 & 60,8 & 70,21 & 2,80 & 82,1 & 0,139 & 84 & 412,9 \\
\hline $\begin{array}{c}\text { Padrão STD OREAS45PA } \\
\text { Encontrado }\end{array}$ & 3,66 & 3,4 & 177,5 & 0,08 & 105 & 808,9 & 619,1 & 16,63 & 0,026 & 6,2 & 0,12 & 1160 & 310,9 & 18,61 & 47,7 & 13,9 & 0,155 & 227 & 117,7 \\
\hline $\begin{array}{c}\text { Padrão STD OREAS45PA } \\
\text { Certificado }\end{array}$ & 3,34 & 4,2 & 187,0 & 0,1 & 104,0 & 879,0 & 600,0 & 16,6 & 0,030 & 5,8 & 0,1 & 1130,0 & 281,0 & 19,0 & 43,0 & 14,0 & 0,1 & 221,0 & 119,0 \\
\hline
\end{tabular}


Tabela 6.2.1- Parâmetros físico-químicos da região do emissário submarino do TEBAR.

\begin{tabular}{|c|c|c|c|c|c|c|c|c|c|c|c|c|c|c|c|c|c|}
\hline 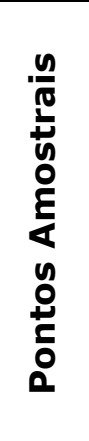 & 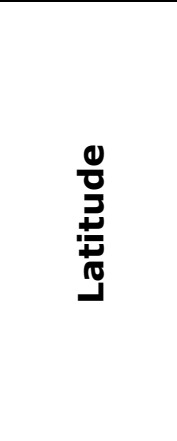 & 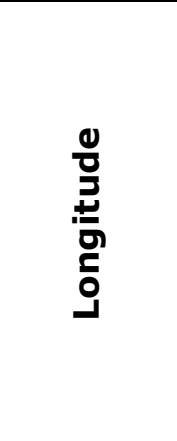 & $\begin{array}{l}\frac{\pi}{0} \\
\frac{0}{0} \\
0 \\
\frac{\pi}{0} \\
\frac{0}{0} \\
\frac{0}{1}\end{array}$ & 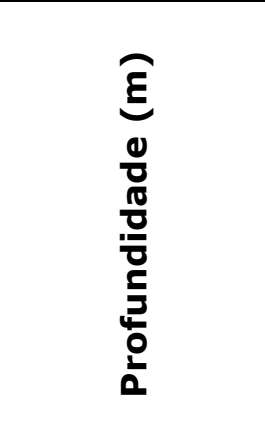 & 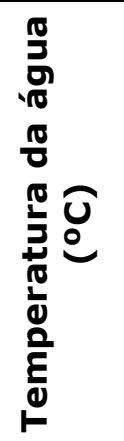 & 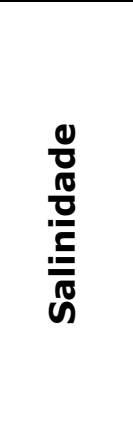 & 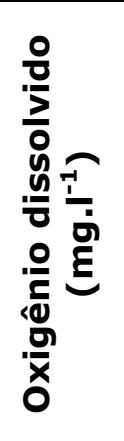 & $\frac{I}{\Omega}$ & $\begin{array}{l}E \\
Z \\
己 \\
N \\
\frac{0}{0} \\
0 \\
\frac{2}{3} \\
1\end{array}$ & 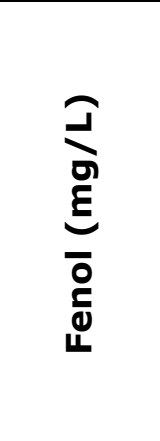 & $\begin{array}{l}n \\
\mathbb{0} \\
x \\
\mathbb{0} \\
0 \\
0 \\
0 \\
0 \\
0 \\
0 \\
0\end{array}$ & 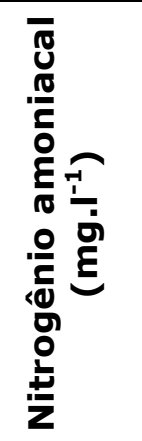 & 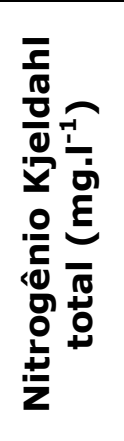 & 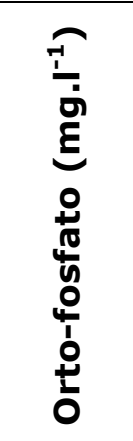 & 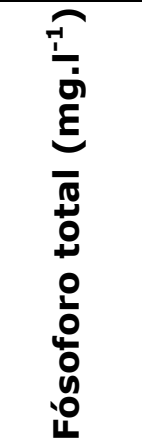 & 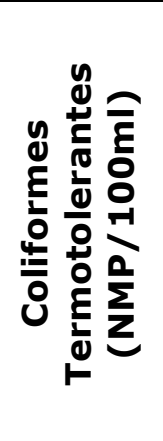 & 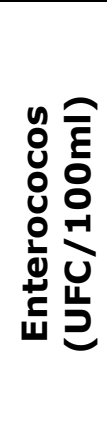 \\
\hline \multicolumn{4}{|c|}{ CONAMA $20 / 86$ e $357 / 05$} & & & $\geq 30$ & 6 & 6,5 a 8,5 & & & 0 & 0,4 & & & 0,062 & 1000 & 100 \\
\hline \multirow[t]{3}{*}{ T1 } & 23,8055 & 45,3868 & $15: 00$ & Superfície (0) & 27,77 & 35,36 & 6,59 & 7,97 & 1,8 & $<0,003$ & $<10$ & $<0,01$ & $<0,1$ & $<0,01$ & $<0,01$ & $<1$ & $<1$ \\
\hline & & & $15: 14$ & Meio (8) & 26,39 & 35,59 & 6,36 & 8,11 & 0,84 & $<0,003$ & $*$ & $<0,01$ & $<0,1$ & $<0,01$ & $<0,01$ & $<1$ & $<1$ \\
\hline & & & $15: 20$ & Fundo (16) & 23,78 & 35,82 & 5,81 & 8,1 & 1,2 & $<0,003$ & $*$ & $<0,01$ & $<0,1$ & $<0,01$ & $<0,01$ & $<1$ & $<1$ \\
\hline \multirow[t]{3}{*}{ T2 } & 23,8046 & 45,3868 & $15: 33$ & Superfície (0) & 27,98 & 35,37 & 6,57 & 7,17 & 2,1 & $<0,003$ & $<10$ & $<0,01$ & $<0,1$ & $<0,01$ & $<0,01$ & $<1$ & $<1$ \\
\hline & & & $15: 39$ & Meio (6) & 26,91 & 35,49 & 6,43 & 7,55 & 1,3 & $<0,003$ & $*$ & $<0,01$ & $<0,1$ & $<0,01$ & $<0,01$ & 12 & $<1$ \\
\hline & & & $15: 44$ & Fundo (12) & 25,69 & 35,71 & 6,14 & 7,82 & 2,7 & $<0,003$ & * & $<0,01$ & $<0,1$ & $<0,01$ & $<0,01$ & $<1$ & $<1$ \\
\hline \multirow[t]{3}{*}{ T3 } & 23,8055 & 45,3858 & $10: 14$ & Superfície (0) & 27,26 & 35,32 & 6,33 & 6,62 & 1,5 & $<0,003$ & $<10$ & $<0,01$ & $<0,1$ & $<0,01$ & $<0,01$ & $<1$ & $<1$ \\
\hline & & & $10: 20$ & Meio (11) & 25,32 & 35,67 & 6,14 & 6,95 & 1,1 & $<0,003$ & $*$ & $<0,01$ & $<0,1$ & $<0,01$ & $<0,01$ & $<1$ & $<1$ \\
\hline & & & $10: 26$ & Fundo (22) & 22,08 & 35,99 & 5,42 & 7,72 & $\begin{array}{c}1+1 \\
1\end{array}$ & $<0,003$ & $*$ & $<0,01$ & $<0,1$ & $<0,01$ & $<0,01$ & $<1$ & $<1$ \\
\hline \multirow[t]{3}{*}{ T4 } & 23,8064 & 45,3868 & $14: 35$ & Superfície (0) & 27,53 & 35,35 & 6,5 & 7,76 & 1,8 & $<0,003$ & $<10$ & $<0,01$ & $<0,1$ & $<0,01$ & $<0,01$ & $<1$ & $<1$ \\
\hline & & & $14: 44$ & Meio (10) & 26,27 & 35,65 & 6,41 & 7,86 & 0,78 & $<0,003$ & $*$ & $<0,01$ & $<0,1$ & $<0,01$ & $<0,01$ & 16 & 2 \\
\hline & & & $14: 50$ & Fundo (20) & 22,44 & 35,92 & 5,28 & 7,73 & 1,3 & $<0,003$ & $*$ & $<0,01$ & $<0,1$ & $<0,01$ & $<0,01$ & 10 & $<1$ \\
\hline \multirow[t]{3}{*}{ T5 } & 23,8061 & 45,3886 & $14: 05$ & Superfície (0) & 27,66 & 35,39 & 6,39 & 7,33 & 1,9 & $<0,003$ & $<10$ & $<0,01$ & $<0,1$ & $<0,01$ & $<0,01$ & $<1$ & $<1$ \\
\hline & & & $14: 11$ & Meio ( 7 ) & 26,46 & 35,6 & 6,38 & 7,3 & 1,1 & $<0,003$ & $*$ & $<0,01$ & $<0,1$ & $<0,01$ & $<0,01$ & $<1$ & $<1$ \\
\hline & & & $14: 19$ & Fundo (14) & 25,56 & 35,73 & 6,06 & 7,6 & 1,3 & $<0,003$ & $*$ & $<0,01$ & $<0,1$ & $<0,01$ & $<0,01$ & $<1$ & $<1$ \\
\hline \multirow[t]{3}{*}{ T6 } & 23,8048 & 45,3886 & $16: 30$ & Superfície (0) & 27,94 & 35,4 & 6,46 & 7,73 & 2,6 & $<0,003$ & $<10$ & $<0,01$ & $<0,1$ & $<0,01$ & $<0,01$ & $<1$ & $<1$ \\
\hline & & & $16: 37$ & Meio (4) & 27,09 & 35,46 & 6,51 & 7,54 & 1,9 & $<0,003$ & $*$ & $<0,01$ & $<0,1$ & $<0,01$ & $<0,01$ & 2 & 5 \\
\hline & & & $16: 43$ & Fundo (8) & 26,22 & 35,63 & 6,31 & 7,47 & 1,1 & $<0,003$ & * & $<0,01$ & $<0,1$ & $<0,01$ & $<0,01$ & $<1$ & $<1$ \\
\hline \multirow[t]{3}{*}{ T7 } & 23,8037 & 45,3868 & $16: 10$ & Superfície $(0)$ & 27,99 & 35,38 & 6,46 & 7,47 & 2 & $*$ & $<10$ & $<0,01$ & $<0,1$ & $<0,01$ & $<0,01$ & $<1$ & 5 \\
\hline & & & $16: 12$ & Meio (5) & 26,98 & 35,49 & 6,45 & 7,19 & 1,3 & * & $*$ & $<0,01$ & $<0,1$ & $<0,01$ & $<0,01$ & 22 & $<1$ \\
\hline & & & $16: 15$ & Fundo (11) & 25,86 & 35,7 & 6,25 & 7,36 & 0,79 & * & $*$ & $<0,01$ & $<0,1$ & $<0,01$ & $<0,01$ & 3 & $<1$ \\
\hline \multirow[t]{3}{*}{ T8 } & 23,8055 & 45,3849 & $11: 04$ & Superfície (0) & 27,12 & 35,33 & 6,36 & 6,23 & 1,2 & * & $<10$ & $<0,01$ & $<0,1$ & $<0,01$ & $<0,01$ & $<1$ & $<1$ \\
\hline & & & $11: 10$ & Meio (15) & 23,97 & 35,81 & 5,83 & 6,77 & 0,52 & * & $*$ & $<0,01$ & $<0,1$ & $<0,01$ & $<0,01$ & 1 & $<1$ \\
\hline & & & $11: 16$ & Fundo (30) & 19,74 & 36,05 & 4,7 & 7,09 & 1 & * & $*$ & $<0,01$ & $<0,1$ & $<0,01$ & $<0,01$ & 1 & $<1$ \\
\hline \multirow[t]{3}{*}{ T9 } & 23,8071 & 45,3861 & $12: 00$ & Superfície (0) & 27,51 & 35,34 & 6,44 & 5,79 & 2,1 & * & $<10$ & $<0,01$ & $<0,1$ & $<0,01$ & $<0,01$ & $<1$ & 12 \\
\hline & & & $12: 04$ & Meio (13) & 25,87 & 35,74 & 6,33 & 5,88 & 0,35 & * & $*$ & $<0,01$ & $<0,1$ & $<0,01$ & $<0,01$ & $<1$ & $<1$ \\
\hline & & & $12: 10$ & Fundo (27) & 20,16 & 36,04 & 4,78 & 5,89 & 2,5 & * & * & $<0,01$ & $<0,1$ & $<0,01$ & $<0,01$ & $<1$ & $<1$ \\
\hline \multirow[t]{3}{*}{ T10 } & 23,8074 & 45,3889 & $13: 30$ & Superfície (0) & 27,53 & 35,37 & 6,5 & 6,83 & 1,2 & * & $<10$ & $<0,01$ & $<0,1$ & $<0,01$ & $<0,01$ & 2 & $<1$ \\
\hline & & & $13: 35$ & Meio (8) & 26,17 & 35,65 & 6,41 & 6,89 & 0,62 & * & $*$ & $<0,01$ & $<0,1$ & $<0,01$ & $<0,01$ & 1 & $<1$ \\
\hline & & & $13: 39$ & Fundo (16) & 22,54 & 35,93 & 5,5 & 6,75 & 1 & * & * & $<0,01$ & $<0,1$ & $<0,01$ & $<0,01$ & $<1$ & $<1$ \\
\hline
\end{tabular}

Obs.: Dados fornecidos pela Companhia Ambiental do Estado de São Paulo (CETESB).* sem infromação 
Tabela 6.2.2.2.2A - Dados de metais e elementos-traços contido no sedimento da região do emissário do TEBAR.

\begin{tabular}{|c|c|c|c|c|c|c|c|c|c|c|c|c|c|c|c|c|c|c|c|}
\hline $\begin{array}{l}\mathbb{J} \\
\mathbb{0} \\
0 \\
0 \\
0 \\
0 \\
0 \\
0 \\
0 \\
0\end{array}$ & 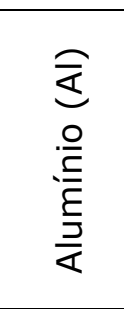 & 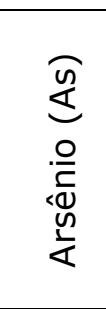 & 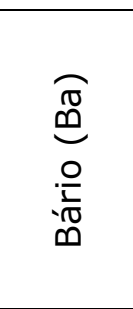 & 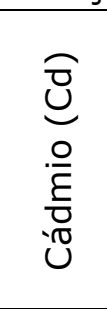 & $\begin{array}{l}\overline{0} \\
\dot{U} \\
0 \\
\frac{0}{\pi} \\
0 \\
0\end{array}$ & $\begin{array}{l}\text { U } \\
\text { O } \\
\text { ¿े } \\
\text { U. }\end{array}$ & $\begin{array}{l}\widehat{3} \\
0 \\
0 \\
0 \\
0\end{array}$ & 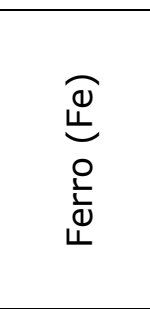 & 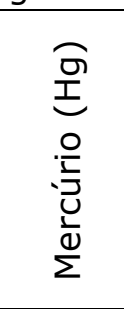 & 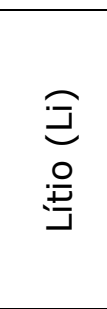 & 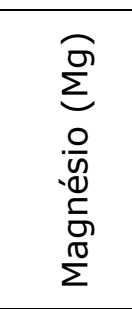 & 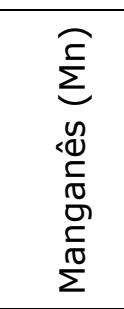 & $\begin{array}{l}\widehat{\bar{z}} \\
\overline{0} \\
\overline{\frac{\sigma}{z}}\end{array}$ & 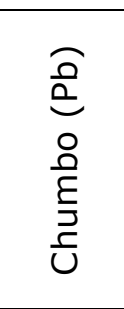 & 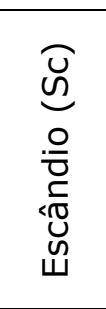 & 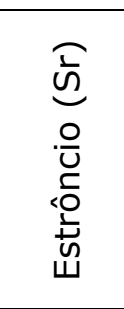 & 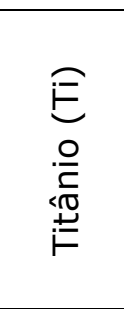 & $\begin{array}{l}\mathcal{Z} \\
.0 \\
.0 \\
\frac{1}{\pi} \\
\frac{\pi}{\pi} \\
>\end{array}$ & $\begin{array}{l}\widehat{\mathcal{N}} \\
\stackrel{O}{\mathbf{N}} \\
\stackrel{\bar{N}}{ }\end{array}$ \\
\hline Unidade & $\%$ & $\mathrm{ppm}$ & $\mathrm{ppm}$ & $\mathrm{ppm}$ & $\mathrm{ppm}$ & $\mathrm{ppm}$ & $\mathrm{ppm}$ & $\%$ & $\mathrm{ppm}$ & $\mathrm{ppm}$ & $\%$ & $\mathrm{ppm}$ & $\mathrm{ppm}$ & $\mathrm{ppm}$ & $\mathrm{ppm}$ & $\mathrm{ppm}$ & $\%$ & $\mathrm{ppm}$ & $\mathrm{ppm}$ \\
\hline Limite de Detecção & 0,01 & 0,1 & 0,5 & 0,01 & 0,1 & 0,5 & 0,01 & 0,01 & 0,005 & 0,1 & 0,01 & 1 & 0,1 & 0,01 & 0,1 & 0,5 & 0,001 & 2 & 0,1 \\
\hline Nível 1 (CONAMA, 2004) & & 8,2 & & 1,2 & & 81 & 34 & & 0,15 & & & & 20,9 & 46,7 & & & & & 150 \\
\hline Nível 2 (CONAMA, 2004) & & 70 & & 9,6 & & 370 & 270 & & 0,71 & & & & 51,6 & 218 & & & & & 410 \\
\hline TEL (CCME, 2002) & & 7,24 & & 0,7 & & 52,3 & 18,7 & & 0,13 & & & & 15,9 & 30,2 & & & & & 124 \\
\hline PEL (CCME, 2002) & & 41,6 & & 4,2 & & 160 & 108 & & 0,7 & & & & 42,8 & 112 & & & & & 271 \\
\hline $\mathrm{T} 1$ & 2,50 & 8,9 & 60,8 & 0,01 & 7,8 & 37,7 & 10,91 & 2,78 & 0,026 & 37,3 & 1,17 & 505 & 14,8 & 21,75 & 5,5 & 150,6 & 0,047 & 43 & 59,8 \\
\hline $\mathrm{T} 2$ & 2,46 & 8,4 & 68,8 & 0,03 & 7,3 & 36,5 & 10,08 & 2,70 & 0,031 & 35,1 & 1,10 & 516 & 14,9 & 21,45 & 5,4 & 158,0 & 0,046 & 42 & 59,2 \\
\hline T3 & 1,93 & 6,7 & 216,7 & 0,03 & 6,0 & 31,0 & 11,95 & 2,22 & 0,019 & 25,7 & 0,87 & 345 & 13,1 & 17,34 & 4,1 & 354,2 & 0,039 & 32 & 69,4 \\
\hline $\mathrm{T} 4$ & 2,29 & 8,5 & 50,4 & 0,02 & 7,2 & 34,0 & 9,21 & 2,53 & 0,030 & 33,1 & 1,00 & 442 & 13,9 & 18,34 & 5,2 & 189,7 & 0,044 & 37 & 52,9 \\
\hline T5 & 2,55 & 9,6 & 30,8 & 0,03 & 7,6 & 37,7 & 10,63 & 2,81 & 0,032 & 35,8 & 1,14 & 641 & 15,8 & 21,85 & 5,7 & 159,5 & 0,048 & 43 & 58,5 \\
\hline T6 & 2,45 & 8,6 & 31,3 & 0,03 & 7,4 & 36,2 & 10,13 & 2,71 & 0,033 & 33,8 & 1,08 & 496 & 14,3 & 21,78 & 5,6 & 143,0 & 0,051 & 42 & 57,0 \\
\hline $\mathrm{T7}$ & 2,65 & 9,2 & 30,2 & 0,03 & 7,8 & 39,6 & 10,80 & 2,89 & 0,036 & 37,6 & 1,15 & 610 & 15,5 & 22,10 & 5,9 & 143,8 & 0,050 & 45 & 59,4 \\
\hline T8 & 2,39 & 8,2 & 27,6 & 0,03 & 7,6 & 36,0 & 31,49 & 2,62 & 0,032 & 34,2 & 1,10 & 512 & 15,4 & 20,16 & 5,3 & 170,9 & 0,042 & 41 & 56,2 \\
\hline T9 & 2,49 & 7,8 & 35,0 & 0,03 & 8,0 & 38,4 & 11,41 & 2,80 & 0,037 & 38,7 & 1,12 & 593 & 16,1 & 23,39 & 5,4 & 141,0 & 0,046 & 43 & 63,2 \\
\hline T10 & 2,19 & 8,9 & 29,7 & 0,06 & 6,9 & 35,4 & 38,10 & 2,52 & 0,031 & 32,7 & 1,04 & 455 & 17,2 & 19,80 & 5,0 & 150,2 & 0,042 & 40 & 70,5 \\
\hline Mín. & 1,93 & 6,7 & 27,6 & 0,01 & 6 & 31 & 9,21 & 2,22 & 0,019 & 25,7 & 0,87 & 345 & 13,1 & 17,34 & 4,1 & 141 & 0,039 & 32 & 52,9 \\
\hline Máx. & 2,65 & 9,6 & 216,7 & 0,06 & 8 & 39,6 & 38,1 & 2,89 & 0,037 & 38,7 & 1,17 & 641 & 17,2 & 23,39 & 5,9 & 354,2 & 0,051 & 45 & 70,5 \\
\hline $\bar{x}$ & 2,39 & 8,48 & 58,13 & 0,03 & 7,36 & 36,25 & 15,47 & 2,658 & 0,031 & 34,4 & 1,077 & 511,5 & 15,1 & 20,8 & 5,31 & 176,1 & 0,046 & 40,8 & 60,61 \\
\hline$s$ & 0,21 & 0,81 & 57,59 & 0,01 & 0,58 & 2,44 & 10,33 & 0,20 & 0,01 & 3,66 & 0,09 & 87,66 & 1,17 & 1,86 & 0,50 & 64,31 & 0,00 & 3,77 & 5,60 \\
\hline CTR & 2,26 & 7,7 & 30,4 & 0,01 & 7,1 & 34,6 & 9,25 & 2,51 & 0,021 & 32,1 & 0,92 & 398 & 13,9 & 17,99 & 4,9 & 108,1 & 0,051 & 37 & 52,4 \\
\hline $\begin{array}{l}\text { Padrão STD DS7 } \\
\text { Encontrado }\end{array}$ & 1,04 & 53.2 & 391,8 & 6,1 & 9,3 & 219,3 & 110,3 & 2,4 & 0,191 & 27,5 & 1,04 & 606 & 60,8 & 70,21 & 2,8 & 82,1 & 0,139 & 84 & 412,9 \\
\hline $\begin{array}{l}\text { Padrão STD DS7 } \\
\text { Certificado }\end{array}$ & 0,959 & 48,2 & 370,3 & 6,38 & 9,7 & 179 & 109 & 2,39 & 0,2 & 29,3 & 1,05 & 627 & 56 & 70,6 & 2,5 & 68,7 & 0,124 & 84 & 411 \\
\hline $\begin{array}{c}\text { Padrão STD OREAS45PA } \\
\text { Encontrado }\end{array}$ & 3,66 & 3,4 & 177,5 & 0,08 & 105 & 808,9 & 619,1 & 16,63 & 0,026 & 6,2 & 0,12 & 1160 & 310,9 & 18,61 & 47,7 & 13,9 & 0,155 & 227 & 117,7 \\
\hline $\begin{array}{c}\text { Padrão STD OREAS45PA } \\
\text { Certificado }\end{array}$ & 3.34 & 4,2 & 187 & 0,09 & 104 & 873 & 600 & 16,559 & 0,03 & 5,8 & 0,095 & 1130 & 281 & 19 & 43 & 14 & 0,124 & 221,0 & 119 \\
\hline
\end{tabular}




\section{ANEXO 5}

Tabela 6.3.2.1 - Concentração de elementos-traço das carapaças de $A$. tepida da região do emissário do Araçá

\begin{tabular}{|c|c|c|c|c|c|c|c|}
\hline Amostra & Ca (ppm) & $\mathrm{Mg}(\mathrm{ppb})$ & $\mathrm{Sr}(\mathrm{ppb})$ & $\mathrm{Mn}(\mathrm{ppb})$ & $\mathrm{Ba}(\mathrm{ppb})$ & $\mathrm{Zn}(\mathrm{ppb})$ & $\mathrm{Al}(\mathrm{ppb})$ \\
\hline $\mathrm{A} 1 \mathrm{C}$ & 0,64 & 1,13 & 1,66 & $<0,01$ & 0,04 & 1,65 & 1,48 \\
\hline$A 2 c$ & 3,60 & 24,49 & 11,49 & 2,53 & 0,23 & 2,40 & 10,81 \\
\hline$A 3 C$ & 4,96 & 14,52 & 15,33 & 6,75 & 0,09 & 0,71 & 2,32 \\
\hline$A 4 C$ & 3,47 & 9,03 & 10,94 & $<0,01$ & 0,11 & 2,07 & 2,68 \\
\hline$A 5 C$ & 1,59 & 3,71 & 4,85 & $<0,01$ & 0,05 & 0,99 & 2,40 \\
\hline$A 6 c$ & 2,35 & 5,41 & 7,34 & $<0,01$ & 0,12 & 2,32 & 2,29 \\
\hline$A 7 C$ & 2,71 & 5,62 & 7,83 & $<0,01$ & 0,10 & 0,77 & 1,34 \\
\hline$A 8 c$ & 1,31 & 7,09 & 4,21 & $<0,01$ & 0,09 & 0,51 & 5,03 \\
\hline A9c & 2,55 & 6,65 & 7,52 & 0,72 & 0,20 & 0,72 & 4,95 \\
\hline $\mathrm{A} 10 \mathrm{c}$ & 3,48 & 7,96 & 10,91 & $<0,01$ & 0,12 & 1,27 & 2,92 \\
\hline Mín. & 0,64 & 1,13 & 1,66 & 0,72 & 0,04 & 0,51 & 1,34 \\
\hline Máx. & 4,96 & 24,49 & 15,33 & 6,75 & 0,23 & 2,40 & 10,81 \\
\hline CTRc & 1,11 & 7,67 & 3,12 & $<0,01$ & 0,26 & 4,03 & 3,28 \\
\hline $\mathrm{A} 1$ & 1,36 & 10,63 & 3,96 & 1,54 & 0,21 & 2,42 & 6,22 \\
\hline $\mathrm{A} 2$ & 2,86 & 13,90 & 8,50 & 2,51 & 0,11 & 0,93 & 2,14 \\
\hline A3 & 2,51 & 10,96 & 7,63 & $<0,01$ & 0,17 & 0,89 & 5,92 \\
\hline A4 & 2,29 & 3,50 & 6,38 & $<0,01$ & 0,06 & 0,89 & 3,16 \\
\hline A5 & 5,93 & 10,59 & 17,46 & 0,54 & 0,05 & 1,07 & 3,93 \\
\hline A6 & 3,90 & 8,87 & 11,61 & 0,37 & 0,09 & 2,10 & 3,56 \\
\hline A7 & 5,45 & 10,88 & 15,82 & 0,50 & 0,09 & 0,72 & 3,01 \\
\hline A8 & 5,35 & 20,34 & 17,00 & 6,83 & 0,17 & 1,40 & 12,37 \\
\hline A9 & 2,12 & 6,62 & 6,08 & 0,19 & 0,04 & 2,71 & 1,32 \\
\hline A10 & 1,40 & 3,56 & 4,07 & $<0,01$ & 0,02 & 5,19 & 2,78 \\
\hline Mín. & 1,36 & 3,50 & 3,96 & 0,19 & 0,02 & 0,72 & 1,32 \\
\hline Máx. & 5,93 & 20,34 & 17,46 & 6,83 & 0,21 & 5,19 & 12,37 \\
\hline CTR & 3,34 & 6,90 & 10,03 & 0,19 & 0,23 & 2,33 & 2,63 \\
\hline
\end{tabular}

Obs.: c - Carapaças coradas 


\section{ANEXO 6}

Tabela 6.3.2.2 - Concentração de elementos-traço das carapaças de $A$. tepida da região do emissário do TEBAR

\begin{tabular}{|c|c|c|c|c|c|c|c|c|c|}
\hline Amostra & $\begin{array}{c}\mathrm{Ca} \\
(\mathrm{ppm})\end{array}$ & $\begin{array}{c}\mathrm{Mg} \\
(\mathrm{ppb})\end{array}$ & $\begin{array}{c}\mathrm{Sr} \\
(\mathrm{ppb})\end{array}$ & $\begin{array}{c}M n \\
(p p b)\end{array}$ & $\begin{array}{c}\mathrm{Fe} \\
(\mathrm{ppb})\end{array}$ & Li (ppb) & $\begin{array}{c}\mathrm{Ba} \\
(\mathrm{ppb})\end{array}$ & $\begin{array}{c}\mathrm{Zn} \\
(\mathrm{ppb})\end{array}$ & Al (ppb) \\
\hline $\mathrm{T} 1 \mathrm{c}$ & 1,39 & 3,37 & 4,01 & $<0,01$ & 1,89 & 0,78 & 0,15 & 2,29 & 1,85 \\
\hline $\mathrm{T} 2 \mathrm{c}$ & 0,64 & 1,36 & 1,85 & $<0,01$ & 1,22 & 0,74 & 0,06 & 0,99 & 1,95 \\
\hline T3c & 0,56 & 0,95 & 1,47 & $<0,01$ & 0,31 & 0,79 & 0,01 & 0,36 & \\
\hline $\mathrm{T} 4 \mathrm{c}$ & 0,19 & 0,05 & 0,35 & $<0,01$ & 1,22 & 0,79 & 0,02 & 0,68 & 0,73 \\
\hline T5c & 1,39 & 3,62 & 4,07 & $<0,01$ & 3,21 & 0,70 & 0,23 & 1,36 & 3,61 \\
\hline T6c & 1,44 & 2,38 & 4,32 & $<0,01$ & 1,46 & 0,72 & 0,02 & 0,57 & 1,20 \\
\hline T7c & 0,98 & 1,28 & 2,75 & $<0,01$ & 0,55 & 0,72 & 0,02 & 9,37 & 0,47 \\
\hline T8c & 1,58 & 3,44 & 4,39 & $<0,01$ & 0,51 & 0,76 & 0,01 & 1,76 & 1,08 \\
\hline T9c & 1,66 & 4,11 & 5,16 & $<0,01$ & 3,26 & 0,72 & 0,07 & 6,25 & 3,62 \\
\hline T10c & 0,31 & 0,50 & 0,73 & $<0,01$ & 0,25 & 0,70 & 0,03 & 3,62 & 0,67 \\
\hline Mín & 0,19 & 0,05 & 0,35 & & 0,25 & 0,70 & 0,01 & 0,36 & 0,47 \\
\hline Máx & 1,66 & 4,11 & 5,16 & & 3,26 & 0,79 & 0,23 & 9,37 & 3,62 \\
\hline CTRc & 1,11 & 7,67 & 3,12 & $<0,01$ & 2,21 & 0,71 & 0,26 & 4,03 & 3,28 \\
\hline T1 & 1,66 & 4,11 & 5,16 & $<0,01$ & 3,26 & 0,72 & 0,07 & 6,25 & 3,62 \\
\hline $\mathrm{T} 2$ & 1,65 & 2,70 & 4,70 & $<0,01$ & 2,13 & 0,74 & 0,05 & 0,59 & 1,83 \\
\hline T3 & 0,73 & 5,60 & 1,89 & $<0,01$ & 6,50 & 0,75 & 0,24 & 3,22 & 2,06 \\
\hline T4 & 1,01 & 2,78 & 2,76 & $<0,01$ & 1,75 & 0,70 & 0,03 & 24,26 & 0,79 \\
\hline T5 & 0,85 & 1,97 & 2,30 & $<0,01$ & 3,10 & 0,76 & 0,04 & 2,68 & 1,99 \\
\hline T6 & 1,18 & 1,52 & 3,28 & $<0,01$ & 1,16 & 0,75 & 0,01 & 0,50 & 0,74 \\
\hline T7 & 2,22 & 3,89 & 6,78 & $<0,01$ & 2,27 & 0,73 & 0,70 & 1,20 & 2,51 \\
\hline T8 & 1,71 & 4,21 & 5,02 & 0,58 & 6,43 & 0,68 & 0,11 & 1,01 & 2,66 \\
\hline T9 & 1,48 & 3,31 & 4,16 & $<0,01$ & 4,89 & 0,72 & 0,07 & 5,55 & 2,11 \\
\hline T10 & 2,07 & 5,22 & 5,97 & $<0,01$ & 2,75 & 0,79 & 0,11 & 2,08 & 2,04 \\
\hline Mín & 0,73 & 1,52 & 1,89 & $<0,01$ & 1,16 & 0,68 & 0,01 & 0,50 & 0,74 \\
\hline Máx & 2,22 & 5,60 & 6,78 & 0,58 & 6,50 & 0,79 & 0,70 & 24,26 & 3,62 \\
\hline CTR & 3,34 & 6,90 & 10,03 & 0,19 & 7,37 & 0,77 & 0,23 & 2,33 & 2,63 \\
\hline
\end{tabular}

Obs.: c - Carapaças coradas 


\section{REFERÊNCIAS BIBLIOGRÁFICAS}

ABESSA, D. M. S.; CARR, R. S.; RACHID, B. R. F.; SOUSA, E. C. P. M.; HORTELANI, M. A.; SARKIS, J. E. Influence of a Brazilian sewage outfall on the toxicity and contamination of adjacent sediments. Marine Pollution Bulletin 50:875-885. 2005.

AGUDO, E.G. Avaliação do desempenho do emissário submarino de esgotos das cidades de Santos e São Vicente. In: Seminário sobre uma síntese do conhecimento sobre a Baixada Santista, 1, pp. 125-130. São Paulo: CETESB, 1983.

ALMEIDA, F. F. M. The system of continental rifts boardering the Santos Basin, Brazil. Anais da Academia Brasileira de Ciências, 48: 15-26, 1976.

ALMEIDA, F. F. M.; HASUI, Y.; PONÇANO, W. L.;DANTAS, A. S. L.; CARNEIRO, C. R.; MELO, M. S.; BISTRICHI, C. A. Mapa geológico do Estado de São Paulo, escala 1:5000.000 V. I - Nota explicativa. IPT-DMGA, 126p. (Monografia 6). 1981.

ALVE, E. Benthic foraminifera in sediment cores reclecting heavy metal pollution in SØrfjord, Western Norway. Journal of Foraminiferal Research, 21: 1-19. 1991.

ALVE, E. Benthic foraminiferal responses to estuarine pollution: A review. Journal Foraminiferal Research, 25 (3), 190-203. 1995.

BAIRD, C. Environmental Chemistry. New York: W. H. Freeman \& Company, 484 p, 1999.

BARCELLOS, R. L. Distribuição da matéria orgânica sedimentar e o processo sedimentar atual no sistema estuarino-lagunar de Cananéia-Iguape (SP). 2005. Tese (Doutorado em Oceanografia) - Instituto Oceanográfico da Universidade de São Paulo, São Paulo, v.1, 89 p, 2005.

BARCELLOS, R. L. \& FURTADO, V. V. Processo sedimentar atual e a distribuição de carbono e nitrogênio orgânicos no Canal de São Sebastião (SP) e Plataforma Continental adjacente. Revista Brasileira de Oceanografia, 47:207$221,1999$.

BARCELLOS, R. L. \& FURTADO, V. V. Caracterização dos componentes da fração arenosa $(0,500 \mathrm{~mm} / 0,250 \mathrm{~mm})$ no Canal de São Sebastião. Pesquisas em Geociências, 28:35-51, 2001.

BARKER, S.; GREAVES, M.; ELDERFIELD, H. A study of cleaning procedures used for foraminiferal $\mathrm{Mg} / \mathrm{Ca}$ paleothermometry. Geochemistry, Geophysics e Geosystems Journal. 4:9:1-20. 2003.

BENITEZ-NELSON, C. R. The biogeochemical cycling of phosphorus in marine systems, Earth-Science Reviews 51:109-135. 2000. 
BERNER, R. A. Sedimentary pirite formation: na update. Geochim. Cosmochim. Acta: 48: 605-615, 1984.

BOERSMA A. Foraminifera In: BOERSMA, A. \& HAQ, B. Introdution to marine micropaleontology. Nova Iorque: Elsevier, 1978. p. 19-77.

BOYLE, E.A. Cadmium, zinc, copper, and barium in foraminifera tests. Earth and Planetary Science Letters, 53:11-35. 1981.

BRADSHAW, J. S. Laboratory experiments in the ecology of foraminifera. Contributions from the Cushman Foundation for Foraminiferal Research, 12 (3): 87-106. 1961

BROWN, B.E. Heavy metal pollution on coral reefs. In: Salvat, B. (ed.), Human Impacts on Coral Reefs: Facts and Recommendations. Antenne Museum E.P.H.E., French Polynesia, pp. 119-134, 1987.

BRULAND, K. W. Trace elements in sea water, in Chemical Oceanography, v.8 (Ed. J. P. Riley and R. Chester). Academic Press, London, pp. 157-220. 1983.

CALDER, L. M. Chromium in Groundwater. In:NRIAGU, J.; NIERBOER, E. Chromium in the natural and human environments-advances in environmental science and technology. Ontario: John Wiley \& Sons. 31 p. 1988.

CARREIRA, R. Carbono orgâncio e especiação do fósforo em sedimentos da área de influência do Emissário Submarino de Esgotos de Ipanema (ESEI). Dissertação (Mestrado) - Pontifícia Universidade Católica do Rio de Janeiro, Rio de Janeiro. 100p, 1994.

CARPENTER, S.J. \& LOHMANN, K.C. Sr/Mg ratios of modern marine calcite: empirical indicators of ocean chemistry and precipitation rate. Geochimica e Cosmochimica Acta, 56:1837-49. 1992.

CARREIRA, R. S. \& WAGENER, A. L. R. Speciation of sewage derived phosphorus in coastal sediments from Rio de Janeiro, Brazil. Marine Pollution Bulletin, 36: 818-827, 1998.

CASTRO-FILHO, B. M. Wind driven currents in the channel of São Sebastião: winter, 1979. Boletim do Instituto Oceanográfico de São Paulo, 38: 111-132, 1990.

CCME. Canadian Council of Ministers of the Environment. Protocol for derivation of Canadian sediment quality guidelines for the protection of aquatic life: Canadian environmental quality guidelines. Canadian Council of Ministers of the Environment, Winnipeg.1995.

CCME. Canadian Council of Ministers of the Environment. 2002. Canadian sediment quality guidelines for the protection of aquatic life: Summary tables. Updated. In: Canadian environmental quality guidelines, 1999, Canadian Council of Ministers of the Environment, Winnipeg.

CEARRETA, A.; IRABIEN, M. J.; LEORRI, E.; YUSTA, I.; QUINTANILHA, A.; ZABALETA, A. Environmental transformation of the Bilbao estuary, N. Spain: 
microfaunal and geochemical proxies in the recent sedimentary record. Marine Pollution Bulletin, 44: 487-503. 2002

CETESB. Qualidade das águas litorâneas no estado de São Paulo: Balneabilidade das praias 2004/CETESB. São Paulo:CETESB, 2005. 331p.

CERVANTES, C., CAMPOS-GARCIA, J., DEVARS, S., GUTIÉRREZ-CORONA, F., LOZA-TAVERA, H., TORRES-GUZMÁN, J.C., MORENO-SANCHEZ, R. Interactions of chromium with microrganisms and plants. FEMS Microbiology Reviews 25, 335-347. 2001.

CHIEREGATI, L. A.; THEOdOROVICZ, A. M. G.; THEOdOROVICZ, A.; MENEZES, R. G.; CHIODI FILHO, C.; RAMALHO, R. Projeto Folhas Natividade da Serra e Caraguatatuba. SICCT-CPRM. 1:110. 1982.

CONAMA. Conselho Nacional Do Meio Ambiente. Resolução N020, 1986.

CONAMA. Conselho Nacional Do Meio Ambiente. Resolução N0344, 2004.

CONAMA. Conselho Nacional Do Meio Ambiente. Resolução N0357, 2005.

CONSELHO DE AUTORIDADE PORTUÁRIA - CAP. Plano de Desenvolvimento e Zoneamento do Porto de São Sebastião, SP. 2009. Disponível em: <http://www.portodesaosebastiao.com.br/documenta/PDZ-PORTO-DE-SAOSEBASTIAO-08-09.pdf> Acessado em: 17 de novembro de 2009.

CONTI, I. A. Aplicação de técnicas de geoprocessamento na caracterizção de aspectos morfosedimentares do Canal de São Sebastião, Litoral Norte do Estado de São Paulo. Dissertação (Mestrado) - Instituto Oceanográfico, Universidade de São Paulo, São Paulo, 1998.

COSTA, R. L. \& CARREIRA, R. S. 2005. A comparison between faecal sterols and coliform counts in the investigation of sewage contamination in sediments. Brazilian Journal of Oceanography, 53 (3/4): 157:167.

CPRM - Companhia de Pesquisa de Recursos Minerais, 2005. Programa Levantamentos Geológicos Básicos do Brasil, Mapa Geológico do Estado de São Paulo, mapa colorido, folha 2, escala 1:750.000.

CUSHMAN, J. A. Foraminifera, their classification and economic use. 4 ed. Massachusetts: Harvard University Press, 605 p. 1950.

CUSHMAN, J. A. Recent foraminifera from Porto Rico: Publications of the Carnegie Institution of Washington, v. 342, p. 73-84, 1926.

DEBENAY, J.P; PAWLOWSKI, J \& DECROUEZ, D. Les foraminefères actuaels. 3 ed. Paris: Masson, 1996. 329 p.

DEUTSCH, W. J. Groundwater Geochemistry: fundamentals and applications to contamination. Boca Raton, Fla: Lewis Publishers. 221 p. 1997.

DI TORO D. M.; MAHONY, J. H.; HANSEN, D. J.; SCOTT, D. J.; HICKS, M. B.; MAYR, S. M.; REDEMOND, M., "Toxicity of Cadmium in Sediments: The Role of 
the Acid Volatile Sulfides", Environmental Toxicological Chemistry, vol. 9: 1487-1502. 1990.

DULEBA, W.; COIMBRA, J. C.; PETRI, S.; BARBOSA, C. F. Foraminíferos tecamebas e ostracodes recentes utilizados como bioindicadores em estudos ambientais brasileiros.In: Sousa, C. R.G.; Suguio, K.; Santos, M.; Oliveira, P. E. (Eds.). Quaternário do Brasil. ABEQUA. Capítulo 9. Ribeirão Preto, Editora Holos. 2005.

FAGANELLI, J.; MALEJ, A.; PEZDIC. J..; MALACIC, V. C:N:P ratios and stable C isotopic ratios as indicator of sources of organic matter in the Gulf of Trieste (northern Adriatic). Oceanologia Acta, 11 (4), 377-382. 1988.

FOLK, R. L. \& WARD, W. C. Brazos River bar: a study in the significance of grain size parameters: Journal of Sedimentary Petrology, 27: 3-27, 1957.

FONTES, R. F. C. As correntes no canal de São Sebastião. 1995. Dissertação (Mestrado) - Instituto Oceanográfico, Universidade de São Paulo, São Paulo.

FORTIS, M. R. Modelagem comptacional da dispersão da pluma do efluente dos emissários submarinos do TEBAR - Petrobrás. Dissertação (Mestrado) Escola Politécnica - Universidade de São Paulo, São Paulo. 2005.

FRONTALINI, F.; BUOSI, C.; DA PELO, S.; COCCIONI, R; CHERCHI, A.; BUCCI, C. Benthic foraminifera as bio-indicators of trace element pollution in the heavily contaminated Santa Gilla lagoon (Cagliari, Italy). Marine Pollution Bulletin, in press: doi:10.1016/j.marpolbul.2009.01.015, 2009.

FUNDESPA. Levantamento oceanográfico da área diretamente afetada por efluentes dos emissários submarinos de esgotos da SABESP, entre os municípios de São Sebastião e Mongaguá, estado de São Paulo. Relatório final. São Paulo:Fundação de Estudos e Pesquisas Aquáticas, 1999. 2v.

FURTADO, V. V. Contribuição ao estudo da sedimentação atual no Canal de São Sebastião Estado de São Paulo. Tese (Doutorado) - Instituto de Geociências, Universidade de São Paulo, São Paulo. 2v, 1978.

FURTADO, V. V. Sedimentação quaternária no Canal de São Sebastião. Publicação Especial Instituto Oceanográfico da USP, São Paulo, 11: 27 - 35, 1995.

FURTADO, V. V.; RODRIGUES, M.; CONTI, L. A.; BARCELLOS, R. L. História evolutiva da região de São Sebastião. In: Oceanografia de um Ecossistema Subtropical: Plataforma de São Sebastião, SP. Organizadora: Pires-Vanin, A. M. S. Ed. da Universidade de São Paulo. 25-37p. 2008.

GARDA, G. M. Os diques básicos e ultrabásicos da região costeira entre as cidades de São Sebastião e Ubatuba, Estado de São Paulo. Tese (Doutorado) Instituto de Geociências, Universidade de São Paulo, São Paulo. 156p. 1995.

GOLDBERG, E. D. Marine geochemistry. Chemical scavengers of the sea. J. Geol., 62:249-266. 1974. 
GOLDSTEIN, J.I., NEWBURY, D.E., ECHLIN, P., JOY, D.C., LYMAN, C.E., LIFSHIN, E., SAWYER, L., MICHAEL, J.R. Scanning Electron Microscopy and X-ray Microanalysis. Kluwer Academic/Plenum Publishers, New York. 2003.

GONÇALVES, FERNANDO B. E SOUZA, AMARÍLIO P. Disposição Oceânica De Esgotos Sanitários História, Teoria E Prática. Associação Brasileira de Engenharia Sanitária, Rio de Janeiro, 348p., 1997.

GONZALEZ, H., POMARES, M., RAMIREZ, M., TORRES, I., Heavy metals and sediments from the discharge zone of the submarine sewage outfall of Havana City Cuba. Marine Pollution Bulletin 38 (11), 1048-1051, 1999.

GRAY, L.A. Metal Contamination of Sediments Associated with Deepwater Ocean Sewage Outfalls, Sydney, Austrália. Marine Pollution Bulletin, Vol 33, 7-12, 182-189, 1996

GROSS, M. G. Oceanography: A view of the Earth. Prentice-Hall. Englewood Cliffs. New Jersey. 441p, 1990.

GROSS, M. G. Carbon determination. In: Carver, R. E. (Ed.), Procedures in sedimentary petrology. New York:Wiley. p. 573-596, 1971.

GROUSSET, F. E.; QUETEL, C. R.; THOMAS, B.; DONARD, O. F. X.; LAMBERT, C. E.; GUILLARD, F.; MONACO, A. Antropogenic vs. lithogenec origins of trace elements ( $\mathrm{As}, \mathrm{Cd}, \mathrm{Pb}, \mathrm{Rb}, \mathrm{Sb}, \mathrm{Sc}, \mathrm{Sn}, \mathrm{Zn}$ ) in water column particles: northwestern Mediterranean Sea. Marine Chemistry, v. 48, p. 291-310. 1995.

GUBITOSO, S; DULEBA, W; TEODORO, A. C.; PRADA, S. M.; DA ROCHA, M. M.; LAMPARELLI, C. C.; BEVILACQUA, J. E.; MOURA, D. O. Estudo geoambiental da região circunjacente ao emissário submarino de esgoto do Araçá, São Sebastião (SP). Revista Brasileira de Geociências. 38(3): 467-475. 2008.

HAYWARD, B. W., GRENFELL, H. R., REID, C. M., and HAYWARD, K. A. Recent New Zealand shallow-water benthic foraminifera: Taxonomy, ecologic distribution, biogeography, and use in paleoenvironmental assessment: Institute of Geological and Nuclear Sciences Monograph, no. 21, 258 pp. 1999.

HAWKES, S.J. What is a "Heavy Metal"? J. Chem. Educ. 74, 1374.1997.

HEDGES, J. I.\& KEIL, G. R. Sedimentary Organic Matter Preservation: An Assessment and Speculative Synthesis. Marine Chemistry. 49:81-115. 1995.

HERSHELMAN, G. P.; SCHAFER, H. A. ; JAN, T. K.; YOUNG, D. R. Metals in marine sediments near a large California municipal outfall.Marine Pollution Bulletin, 12(4): 131-134, 1981.

HOLZMANN, M., and PAWLOWSKI, J. Taxonomic relationships in the genus Ammonia (Foraminifera) based on ribosomal DNA sequences: Journal of Micropaleontology, v. 19, p. 85-95. 2000.

HONG, S. A.; SHULER, P. J. A Mathematical Model for the Scale-Inhibitor Squeeze Process. SPE Production Engineering Journa. Society of Petroleum Engineers. 3:4:597-606. 1988. 
HÖRCSIK, Z.; OLÁH, V.; BALOGH, A.; MÉSZÁROS, I.; SIMON, L.; LAKATOS., L. Effect of Chromium(VI) on growth, element and photosynthetic pigment composition of Chlorella pyrenoidosa. Acta Biologica Szegediensis. 50(1-2):1923. 2006.

HORTELLANI, M A.; SARKIS, J. E. S.; ABESSA, D. M. S.; SOUSA, E. C. P. M. Avaliação da contaminação por elementos metálicos dos sedimentos do esturário Santos - São Vicente. Química Nova, v.31, p. 10-19. 2008

IVANOV, M. V. The globol biogeochemical surphur cycle. In: Likens, G. E. 1981. (org); Some perpectives of major biogeochemical cycles (SCOPE) (ICSU), New York, 1981.

KATO, W.S., TAKIMOTO, S. \& OGURA, H. Mechanism of induction of hypercalcemia and hyperphosphatemia by lead acetate in the rat. Calcif. Tissue Res. 24:41-46. 1977.

KOLOWITH, L. C.; INGALL, E. D.; BENNER, R. Composition and cycling of marine organic phosphorus, Limnol. Oceanogr. 46:309-320. 2001.

KORNHAUSER, C., WROBEL, K., WROBEL, K., MALACARA, J. M., NAVA, L. E., GOMEZ, L. Possible adverse effect of chromium in occupational exposure of tannery workers. Industrial Health, 40(2), 207-213. 2002.

KENNISH, M.J. Ecology of Estuaries: Anthropogenic Effects. CRC Press Inc, Boca Raton, FL. 1992.

KITAZATO, $\mathrm{H}$. Foraminiferal microhabitats in four marine environments around Japan. Marine Micropaleontology, 24: 29-41. 1994.

LARSSONEUR, C.; BOUYSSE, P.; AUFRET \& J. P. The Superficial Sediments of The English Channel and its Western Approach. Sedimentology, 19 (6): 851864, 1982.

Le CADRE, V. ; DEBENAY, J. P. Morphological and cytological responses of Ammonia (foraminifera) to cooper contamination: Implications for the use of foraminifera as bioindicators of pollution. Environmental Pollution, 143, 304 317. 2006.

LEA, D. W. Trace elements foraminiferal calcite. in:Modern foraminifera. Kluwer Academic Publishers. Gupta, Ed. B. K. S., p. 259-277. 1999.

LEA, D. W.; MARTIN, P.A.; SHAN, D.A.; SPERO, H.J. Calcium uptake and calcification rate in the planktonic foraminifer Orbulina universa. Journal of Foraminiferal Research, 25:14-23. 1995.

LEE, D S.; GARLAND, J.A.; FOX, A. A. Atmospheric concentrations of trace elements in urban areas of the United Kinddom. Atmospheric Envrionment, 28, 2691-2713. 1994 
LEGG J O. \& BLACK C A. Determination of organic phosphorus in soils: II. Ignition method. Soil Science Society of America Proceedings 19:139-143, 1955.

LEGHOUCHI, E.; LAIB, E.; GUERBET, M. Evaluation of chromium contamination in water, sediment and vegetation caused by the tannery of Jijel (Algeria): a case study. 153:111-117. 2009.

LIPPS, J.H. Fossil Prokaryotes and Protists. 2 ed. Massachussets: Blackwell Scientific Publications, 1993. 342 p.

LIU, Q. T.; DIAMOND, M. L.; GINGRICH, S. E.; ONDOV, J. M.; MACIEJCZYK, P.; STERN, G. A. Accumulation of metals, trace elements and semi-volatile organic compouns on exterior window surfaces in Baltimore. Environmental Pollution 122, 51-61. 2003.

LOEBLICH, A. R. \& TAPPAN, H. 1964. Parte C, Protista2, Sarcodina chiefly "Thecamoebians" and Foraminífera. In: Moore, R.C., ed. Treatise on invertebrate paleontology. New York: The University Kansas Press, vol. 1, 510 p., vol. 2, 390 p. 1964.

LOEBLICH, A. R. \& TAPPAN, H. Foraminiferal genera and their classification. 1 ed. Nova Iorque: Van Nostrand Reinhold Company, v.1, 970 p., v.2, 847 p. 1988.

LU, X.; LI, L. Y.; WANG, L.; LEI, K.; HUANG, J.; ZHAI, Y. Contamination assessment of mercury and arsenic in roadway dust from Baoji, China. Atmospheric Environment, v.43, p. 2489-2496. 2009.

LUIZ-SILVA, W.; MATOS, R. H. R.; KRISTOSH G. C.; MACHADO, W. Variabilidade espacial e sazonal da concentração de elementos-traço em sedimentos do sistema estuarino de Santos-Cubatão (SP). Química Nova, v. 29, p. 256-263. 2006.

MASON, B. \& MOORE, C. B. Principles of Geochemistry. John Wiley \& Sons. 4 ed. 1982

MAHIQUES, M. M.; FURTADO, V. V. \& TESSLER, M. G. Origin and evolution of isolated depressions on the coastal region of São Paulo and Rio de Janeiro states. Special publication of International Symposium on Global Changes in South America during the Quaternary: past-present-future, São Paulo. Associação Brasileira de Estudos do Quaternário. 1: 285-288, 1989.

MARCELLINO, E. B. Sistematização dos projetos de emissários submarinos da SABESP e avaliação de desempenho através do modelo computacional CORMIX. Dissertação (Mestrado) - Escola Politécnica, Universidade de São Paulo, São Paulo. . 272p. 2000

MARTIN, P. A. \& LEA, D. W. A Simple Evaluation of Cleaning Procedures on Fóssil Benthic Foraminiferal MG/Ca. Geochimistry Geophysics Geosystens. 3:10:1-8, 2002. 
MARTINS, R. V.; PAULA FILHO, F. J.; ROCHA, C. A. S. Geoquímica de fósforo como indicadora da qualidade ambiental e dos processos estuarinos do Rio Jaguaribe - costa nordeste oriental brasileira Química Nova, 2007, v.30 n.5.

MATSCHULLAT, J. Arsenic in the geosphere: a review. Sci. Total Environ. 249, 297-312. 2000.

McTEIR, M. D. K.; RAVENSCROFT, P. D.; RUDKIN, C.S Modified Methods for the Determination of Polyacrylic/Phosphinopolycarboxylic Acid and Polyvinylsulphonic Acid Scale Inhibitors in Oilfield Brines. Society of Petroleum Engineers International Symposium on Oilfield Chemistry. New Orleans, Louisiana, USA. SPE 25160. 1993.

MELO, M. S. DE \& PIRES NETO, A. G. Esboço geológico da Província Costeira entre as serras do Juqueriquerê e do Parati, Estado de São Paulo. In: Simpósio de Geologia Regional, 1, São Paulo, 1977. atas... São Paulo, SBG-NSP, p. 303323. 1977.

MIRANDA, L. B. \& CASTRO-FILHO, B. M. Variabilidade da circulação e do transporte de volume no Canal de São Sebastião (SP): outono de 1980. Publicação Especial do Instituto Oceanográfico,São Paulo, 11:1-9, 1995.

MOREIRA, R. C. A.; BOAVENTURA, G. R. Referência geoquímica regional para a interpretação das concentrações de elementos químicos nos sedimentos da bacia do lago Paranoá - DF. Química Nova, vol. 26, p. 812-820, 2003.

MURRAY, J. W. Ecology and paleoecology of benthic foraminifera. London, Longman Scientific and Technical, 397 p. 1991.

NEIVA, J. Conheça o petróleo. Rio de Janeiro, Expressão e Cultura, 1993.

NELSON, D. L. \& COX, M. M. Lehninger Principles of Biochemistry. 4ed. New York: W. H. Freeman. 1124 p. 2004.

NIEBOER, E. \& JUSYS, A. Biologic chemistry of chromium. In: E. Nieboer and J.O. Nriagu, (Eds), Chromium in the Natural and Human Environments, Advances in Science and Technology, Vol. 20, Wiley, New York, pp. 21-79. 1988.

OCCHIPINTI, A.G. Estudos para o sistema de disposição oceânica dos esgotos de Santos e São Vicente. Revista DAE 86, 155-176, 1972.

OSÓRIO, L.K.V. \& OLIVEIRA, W. Polifosfatos em detergentes em pó comerciais. Química Nova. São Paulo, v. 24, n. 5, p. 700-708, 2001.

PENG, T. C., GITELMAN, N. J. \& GARNER, S. C. Acute lead-induced increase in serum calcium in the rat without increased secretion of calcitonin. Proc. Sot. Exp. Biol. Med. 160:114-117. 1979.

PHILIP, N. A. \& PRITCHARD, T. R. Australia's first deepwater sewage outfalls: Design considerations and environmental performance monitoring. Marine Pllution Bulletin. 33:7-12:140-146. 1996. 
POUNDS, J. G., MORRISON, D., WRIGHT, R., CASCIANO, D. \& SHADDOCK, J. Effect of lead on calcium-mediated cell function in the isolated rat hepatocyte. Toxicol. Appl. Pharmacol. 63:402-408. 1982.

QUETIN, B. \& de ROUVILLE, M. Submarine seer outfalls - A design manual. Marine Pollution Bulletin. 17:4:133-183. 1986.

RAHN K. A. Sources of trace elements in aerosols - an approach to clean air. Ph.D. Thesis, University of Michegan, Ann Arbor. 1971.

RAITZSCH, M., DUEÑAS-BOHÓRQUEZ, A., REICHART, G.J., NOOIJER, L. J. DE, BICKERT, $\mathrm{T}$. Incorporation of $\mathrm{Mg}$ and $\mathrm{Sr}$ in calcite of cultured benthic foraminifera: impact of calcium concentration and associated calcite saturation state. Biogeosciences, 7: 869-881. 2010.

REBELlO, A. L., PONCIANO, C. R \& MELGES, L. H. Avaliação da produtividade primária e da disponibilidade de nutrientes na Baía de Guanabara. Anais da Academia Brasileira de Ciências 60:419-430, 1988.

RESIG, J.M. Foraminiferal ecology around ocean outfalls off southern California. In: Person, E. (Ed.), Disposal in the Marine Environment. Pergamon Press, London, pp. 104-121, 1960.

ROMANO, R.; BERGAMIN, L.; FINOIA, M. G.; CARBONI, M. G.; AUSILI, A.; GABELLINI.Industrial pollution at Bagnoli (Naples, Italy): Benthic foraminifera as a tool in integrated programs of environmental characterisation. Marine Pollution bulletin. 58:439-457. 2008.

SCHÖEDER, C.J.; SCOTT, D. B. \& MEDIOLI, F.S. Can smaller benthic foraminifera be ignored in paleoenvironmental analyses? Journal of Foraminifera Research. Washington, v. 17, no 2 p.101-110, Abril, 1987.

SCOTT, D. B., MEDIOLI, F.S., SCHAFFER, C. T.Monitoring in Coastal Environments using Foraminifera and Thecamoebian Indicators. 1 ed. Cambridge: Cambridge University Press, 2001. 177 p.

SEIGLIE, G. A. Foraminiferal assemblages as indicators of high organic carbon content in sediments and of polluted waters. American Association of Petroleum Geologists Bulletin. v. 52; no. 11 ; p. 2231-2241, 1968.

SIEGEL, F.R. Environmental Geochemistry of Potentially Toxic Metals. Springer, New York. 2002.

STEIN, R. Accumulation of organic carbon in marine sediments. Lecture Notes in Earth Sciences. Berlin, Springer-Verlag. 217 p, 1991.

STOKER, H. S. Chemistry, a science for today. London: MacMillan, 570p, 1989.

SHEPARD, F.P. Nomenclature based on sand-silt-clay ratios: Journal Sedimentary Petrology, v. 24, p. 151-158, 1954.

SOARES, J. A. Uma contribuição ao estudo do ciclo geoquímico dos metais pesados no ambiente marinho: determinação de cromo total em sedimentos 
da região da Enseada do Flamengo (SP) e Saco do Mamanguá (RJ). Dissertação (Mestrado) - Instituto de Geociências, Universidade de São Paulo, São Paulo. 139p. 1992.

SOTO-JIMÉNEZ, M.; PÁEZ-OSUNA, F.; MORALES-HERNÁNDEZ, F. Selected trace metals in oysters (Crassostrea iridescens) and sediments from the discharge zone of the submarine sewage outfall in Mazatlán Bay (southeast Gulf of California): chemical fractions and bioaccumulation factors. Environmental Pollution, v.114, p. 357-370. 2001.

SUGUIO, K. Introdução à Sedimentologia. São Paulo:Editora Edusp, 1973. 317pp.

TEODORO, A. C. Estudo hidrogeoquímico, sedimentológico e de foraminíferos em áreas de Baixada Santista, SP, submetidas a disposição oceânica de esgotos. Dissertação (Mestrado) - Instituto de Geociências, Universidade de São Paulo, São Paulo. 166p, 2006.

TUREKIAN, K. K.; WEDEPOHL, K. H. Distribution of the elements in some major units of the Eath's crust. Geological Society of America Bulletin, v. 72, p. 175192. 1961

U.S. EPA. 2000. Bioaccumulation Testing and Interpretation for the Purpose of Sediment Quality Assessment. Disponível em:

http://www.epa.gov/waterscience/cs/biotesting/bioaccum.pdf

VILELLA, C. G.; BATISTA, D. S.; BAPTISTA-NETO, J.A.; CRAPEZ, M.; MCALLISTER, J.J. Benthic foraminífera distribution in high polluted sediments from Niterói Harbor (Guanabara Bay), Rio de Janeiro, Brazil. Anais da Academia Brasileira de Ciências, 76 (1), 161-171. 2004.

VINCENT, J.B. Mechanisms of chromium action: low-molecular-weight chromiumbinding substance. Journal of the American College of Nutrition, 18:6-12. 1999.

WAGENER, A. L. R.; BOUCH, C.; MELGES-FIGUEIREDO, L.H.; CARREIRA, R. \& WAGENER, K. Environemental impact on coastal waters off Rio de Janeiro due to sewage discharge via submarine outfall. Chemistry and Ecology 6:19-39, 1992.

WALTON, W. R. 1952. Techniques for recognition of living foraminifera. Contribution of Cushman Foundation for Foraminiferal Research, 3: 56-60.

WATKINS, J.G. Foraminiferal ecology around the Orange County, California, ocean sewer outfall. Micropaleontology 7, 199-206., 1961.

WELLMAN, D.E., REID, D.A., ULERY. A.L. Elevated soil arsenic levels at a former crude oil storage facility - Assessment, remediation, and possible sources. $\mathrm{J}$. Soil Contam. 8, 329-341. 1999.

WERME C \& HUNT C. D. Outfall monitoring overview. Boston: Massachusetts Water Resources Authority. Report 13. 97 p., 2004. 
YAMAGUCHI, N. \& YAMAMOTO, I. Effect of thyrocalcitonin and actinomycin D on the calcium concentration of serum and liver in rats treated with lead. Toxicol. Appl. Pharmacol. 29:223 228. 1974.

YANKO, V.; KRONFELD, J.; FLEXER, A. Response of benthic foraminifera to various pollution sources: implications for pollution monitoring. Journal of Foraminiferal Research, 24, 1-17P., 1994

YANKO, V., AHMAD, M., KAMINSKI, M. Morphological deformities of benthic foraminiferal test in response to pollution by heavy metals: implications for pollution monitoring. Journal of Foraminiferal Research 28, 177-200., 1998.

YANKO, V., ARNOLD, A.J., PARKER, W.C. Effects of marine pollution on benthic foraminifera. In: Sen Gupta, B.K. (Ed.), Modern Foraminifera. Kluwer Academic Publisher, Dordrecht, pp. 217-235., 1999.

ZAGATTO, E.A.G.; JACINTHO, A.O.; REIS, B.F.; KRUG, F.J.; BERGAMIN FILHO, H.; PESSENDA, L.C.R.; MORTATTI, J. \& GINÉ, M.F. Manual de análises de plantas e águas empregando sistemas de injeção em fluxo. Piracicaba: Universidade de São Paulo, CENA/Seção de Química Analítica, 1981. 45p. 